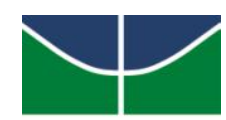

\title{
UnB
}

UNIVERSIDADE DE BRASÍLIA

FACULDADE DE EDUCAÇÃO

PROGRAMA DE PÓS-GRADUAÇÃO EM EDUCAÇÃO

MESTRADO EM EDUCAÇÃO

BLENDA CAVALCANTE DE OLIVEIRA

O TRABALHO DOCENTE NA VERTICALIZAÇÃO DO INSTITUTO FEDERAL DE BRASÍLIA

Brasília - DF 
BLENDA CAVALCANTE DE OLIVEIRA

\section{O TRABALHO DOCENTE NA VERTICALIZAÇÃO DO INSTITUTO FEDERAL DE BRASÍLIA}

Dissertação de Mestrado apresentada ao Programa de Pós-Graduação em Educação da Faculdade de Educação da Universidade de Brasília, como requisito parcial para obtenção do título de Mestre em Educação na linha de Pesquisa Profissão Docente, Currículo e Avaliação (PDCA), sob orientação da $\operatorname{Prof}^{a} \operatorname{Dr}^{a}$ Shirleide Pereira da Silva Cruz.

\section{Brasília - DF}


Ficha catalográfica elaborada automaticamente, com os dados fornecidos pelo(a) autor(a)

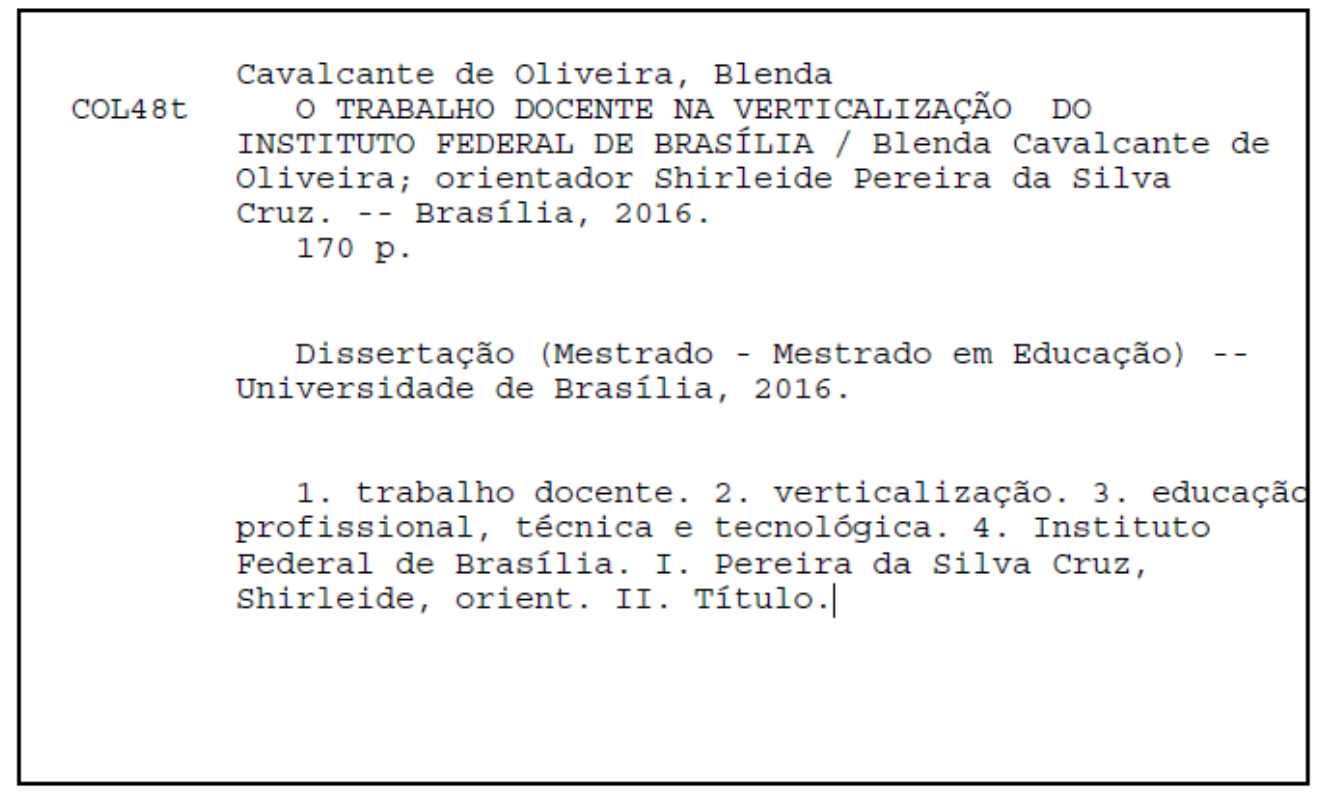


BLENDA CAVALCANTE DE OLIVEIRA

\section{O TRABALHO DOCENTE NA VERTICALIZAÇÃO DO INSTITUTO FEDERAL DE BRASÍLIA}

Dissertação de Mestrado apresentada ao Programa de Pós-Graduação em Educação da Faculdade de Educação da Universidade de Brasília, como requisito parcial para obtenção do título de Mestre em Educação na linha de Pesquisa Profissão Docente, Currículo e Avaliação (PDCA), sob orientação da $\operatorname{Prof}^{\mathrm{a}} \mathrm{Dr}^{\mathrm{a}}$ Shirleide Pereira da Silva Cruz.

Banca Examinadora

Prof $^{a}$ Dr $^{a}$. Shirleide Pereira da Silva Cruz - Orientadora Faculdade de Educação - UnB

$\operatorname{Prof}^{\mathrm{a}} \mathrm{Dr}^{\mathrm{a}}$ Ranilce Mascarenhas Guimarães-Iosif - Membro externo Universidade Católica de Brasília - UCB

Prof $^{a}$. Dr ${ }^{\mathrm{a}}$. Kátia Augusta Curado Pinheiro Cordeiro da Silva - Membro Interno Faculdade de Educação - UnB

Prof $^{a}$. Dr ${ }^{\mathrm{a}}$ Adriana Almeida Sales de Melo - Suplente Faculdade de Educação - UnB 


\section{RESUMO}

A pesquisa analisou o trabalho docente no âmbito da verticalização do Instituto Federal de Brasília (IFB) a partir das determinações específicas da educação profissional e tecnológica (EPT) na totalidade de uma política educacional, que se insere no sistema capitalista com suas contradições e mediações. O método crítico-dialético foi a lente pela qual esta pesquisa buscou a compreensão da realidade, que se entende como contraditória e em permanente transformação, e para isso concebemos o objeto como processo histórico concreto. Os instrumentos e procedimentos utilizados na investigação incluíram pesquisa bibliográfica, levantamento do estado do conhecimento, pesquisa documental, aplicação de questionários e entrevistas com os professores do IFB. Dessa maneira, percebemos que o trabalho docente na verticalização é marcado por ambiguidades, resultando em pares dialéticos. A política educacional levou uma instituição educacional nova para lugares antes desfavorecidos de EPT, mas não necessariamente ofereceu infraestrutura adequada para a realização da verticalização e integração educacional. A não formação docente apareceu marcadamente como um dos elementos que dificultam a integração da educação básica à superior. A polivalência por nível de ensino foi percebida tanto como vantagem quanto desvantagem para o corpo docente do IFB. Os professores pouco se perceberam como parte de um coletivo de trabalhadores da educação, levando a um movimento que tem momentos de coletividade e individualidade na ação docente. A fragmentação do trabalho docente cria empecilhos para a integração da educação básica à superior, ratifica o individualismo e desencoraja o movimento associativo entre os professores. A fragmentação é também resultado da intensificação do trabalho, uma vez que essa sobrecarga reflete no sentido que o professor dá ao trabalho docente e no estabelecimento da identidade docente enquanto uma coletividade. $O$ par satisfação-insatisfação trazido pelo trabalho docente desvelou o princípio da verticalização, apoiado em parte pelos professores do IFB, mas não como está posto na materialidade da constituição da premissa da verticalização. O IFB se mostrou como uma possibilidade no cenário educacional do DF. Trata-se de uma instituição situada em um momento histórico determinado, na qual o trabalho docente pode atuar no processo de formação humana e na perspectiva de outra educação para os que vivem do trabalho.

Palavras-chave: trabalho docente; verticalização; educação profissional, técnica e tecnológica; Instituto Federal de Brasília. 


\begin{abstract}
The research analyzes teaching in the context of the verticalization of the Instituto Federal de Brasília (IFB), based on specific stipulations for Professional and Technological Education (PTE) that are part of the totality represented by Brazil's national Education policy, which is, for its part, inserted in a capitalist system, with its contradictions and mediations. The critical dialectical method is the prism through which this research sought to understand a reality perceived as contradictory and everchanging, and thusly we propose to interpret the object as a concrete historical process. Instruments and procedures used during this investigation include bibliographic review, analysis of the state of knowledge, desk research, surveys and interviews with IFB teachers. We were then able notice the dialectic pairs and the ambiguous effects of teaching in a verticalized context. The education policy brought a new kind of institution to places previously disregarded by PTE, but didn't necessarily provide the adequate infrastructure for the proper verticalization and integration. The lack of teacher training was highlighted as a hurdle for integrating secondary and higher education. Level polyvalence is, at the same time, perceived as an advantage and a disadvantage by IFB teachers, who have a weak perception of themselves as a collective of education workers', which leads to a dynamic that features moments of collective and individual action by the teachers. The fragmentation of teaching labor hinders the integration of secondary and higher education, ratifies individualism, and discourages teacher unionization. Fragmentation is also an outcome of labor intensification, as the overload affects the meaning teachers give to their work and the construction of the teachers' identity as a collective. The satisfaction-dissatisfaction dialectical pair caused by teaching unveiled the principle of verticalization, supported in part by the teachers at the IFB but not in the way posed by the materiality of the constituted premise of verticalization. The IFB has presented itself as a possibility in the educational landscape of Distrito Federal. It's an institution located in a determinate historical moment, in which teaching can function in the process of human formation and in the perspective of another type of education for those that live from labor.
\end{abstract}

Keywords: teaching work; verticalization; Professional, technical and technological education, Instituto Federal de Brasília 


\section{LISTA DE QUADROS}

Quadro 1: Quadro representativo de teses e dissertações relacionadas ao objeto de estudo, considerando o recorte temporal de 2009 a 2016.

Quadro 2: Quadro representativo de artigos relacionados ao objeto de estudo, considerando o recorte temporal de 2009 a 2016.

Quadro 3: Quadro representativo de trabalhos em eventos relacionados ao objeto de estudo, considerando o recorte temporal de 2009 a 2016.

Quadro 4: Quantidade de questionários respondidos em cada campus.

Quadro 5: Professores selecionados para a aplicação das entrevistas.

Quadro 6: Eixos de análise, unidades temáticas, subunidades temáticas e frequências decorrentes dos questionários.

Quadro 7: Eixos de análise, unidades temáticas, subunidades temáticas e frequências decorrentes das entrevistas. 


\section{LISTA DE SIGLAS E ABREVIATURAS}

ANPEd - Associação Nacional de Pós-Graduação e Pesquisa em Educação

BDTD - Biblioteca Digital Brasileira de Teses e Dissertações

BIRD - Banco Interamericano de Desenvolvimento

BM - Banco Mundial

CAPES - Coordenação de Aperfeiçoamento de Pessoal de Nível Superior

CEFET - Centro Federal de Educação Tecnológica

CNE - Conselho Nacional de Educação

$\mathrm{CNPq}$ - Conselho Nacional de Desenvolvimento Científico e Tecnológico

CONCEFET - Conselho de dirigentes dos Centros Federais de Educação Tecnológica

CONEAF - Conselho das Escolas Agrotécnicas Federais

EaD - Educação a Distância

EAF - Escola Agrotécnica Federal

EBTT - Ensino Básico Técnico e Tecnológico

EJA - Educação de Jovens e Adultos

EMI - Ensino Médio Integrado

ENDIPE - Encontro Nacional de Didática e Práticas de Ensino

EPT - Educação profissional e tecnológica

FE - Faculdade de Educação

FEDF - Fundação Educacional do Distrito Federal

FIC - Curso de formação inicial e continuada

FMI - Fundo Monetário Internacional

GDF - Governo do Distrito Federal

IBICT - Instituto Brasileiro de Informação em Ciência e Tecnologia

IES - Instituição de Ensino Superior

IF - Instituto Federal de Educação, Ciência e Tecnologia

IFB - Instituto Federal de Educação, Ciência e Tecnologia de Brasília

INEP - Instituto Nacional de Estudos e Pesquisas Educacionais Anísio Teixeira

LDB - Lei de Diretrizes e Bases da Educação Nacional

MEC - Ministério da Educação

PDCA - Profissão Docente, Currículo e Avaliação

PDI - Plano de Desenvolvimento Institucional

PNE - Plano Nacional de Educação

PPGE - Programa de Pós-Graduação em Educação

RFEPCT - Rede Federal de Educação Profissional, Científica e Tecnológica

SCIELO - Scientific Electronic Library Online

SEDF - Secretaria de Estado de Educação do Distrito Federal

SENEPT - Seminário Nacional de Educação Profissional e Tecnológica

SETEC - Secretaria de Educação Profissional e Tecnológica

SINAES - Sistema Nacional de Avaliação da Educação Superior

TCU - Tribunal de Contas da União

UnB - Universidade de Brasília 


\section{Sumário}

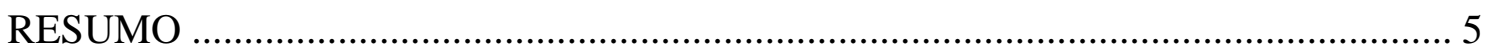

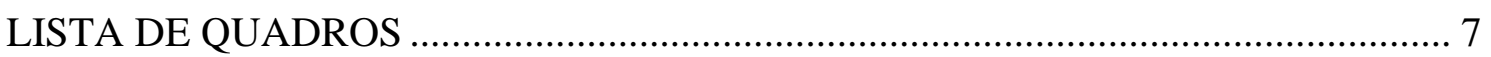

LISTA DE SIGLAS E ABREVIATURAS _.......................................................... 8

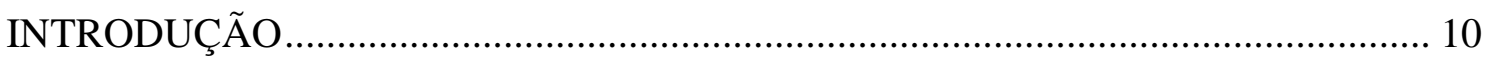

1. O QUE DIZEM AS PESQUISAS: PRODUÇÃO ACUMULADA SOBRE O TRABALHO DOCENTE NA VERTICALIZAÇÃO ................................................. 22

1.1 Perspectivas de análise a partir do estado do conhecimento........................... 41

2. PRINCÍPIO DA VERTICALIZAÇÃO NAS POLÍTICAS PÚBLICAS DE EDUCAÇÃO PROFISSIONAL E TECNOLÓGICA: ASPECTOS HISTÓRICOS E

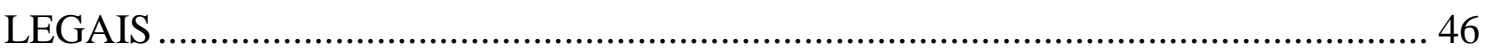

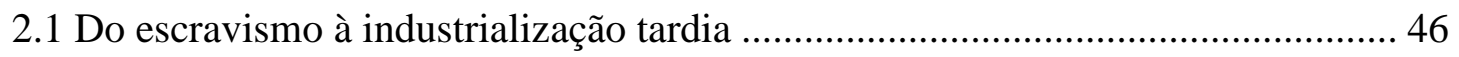

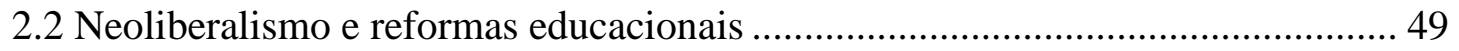

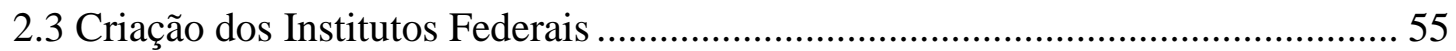

3. INSTITUTOS FEDERAIS: TRABALHO DOCENTE NA VERTICALIZAÇÃO... 61

$3.1 \mathrm{O}$ trabalho docente na verticalização e integração educacional............................ 61

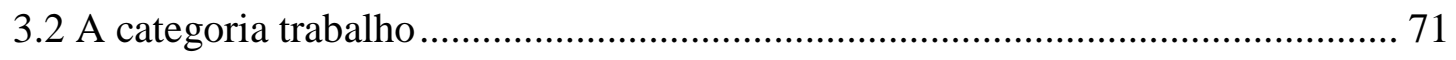

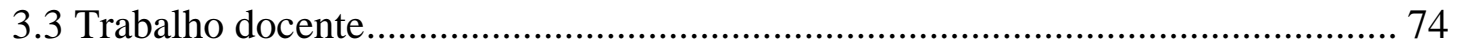

3.4 O trabalho docente no Instituto Federal de Brasília ............................................ 78

4. TRABALHO DOCENTE NA VERTICALIZAÇÃO: AS CONCEPÇÕES DOS

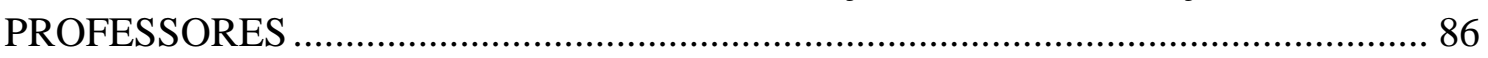

4.1 Itinerário e instrumentos utilizados: questionário e entrevistas ........................... 87

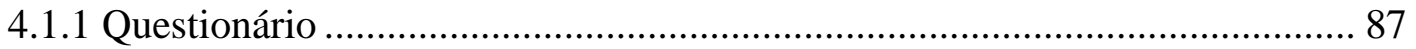

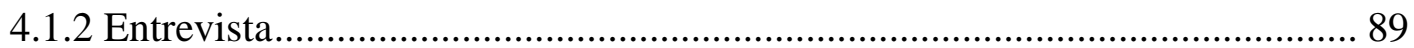

4.2 O que dizem os professores a partir dos questionários e entrevistas ................... 90

4.2.1 Caracterização e perfil dos professores ......................................................... 92

4.2.2 Política de verticalização e integração da educação básica à superior............ 96

4.2.3 Elementos do trabalho docente na verticalização ..................................... 100

4.2.4 Estruturantes do trabalho docente na verticalização .................................. 114

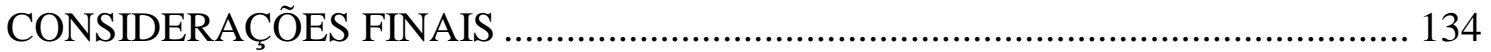

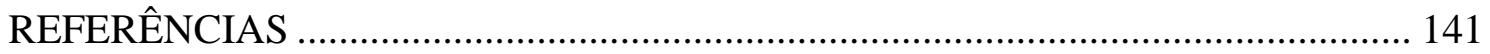

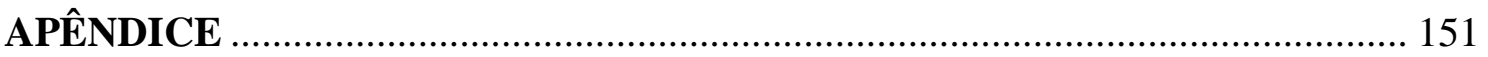




\section{INTRODUÇÃO}

Instrui-vos porque teremos necessidade de toda vossa inteligência. Agitai-vos porque teremos necessidade de todo vosso entusiasmo.

Organizai-vos porque teremos necessidade de toda vossa força. GRAMSCI, A., Ordine Nuovo, Einaudi, 1987.

Esta proposta de pesquisa teve início a partir da inquietação quando a pesquisadora iniciou seu trabalho como professora do Ensino Básico, Técnico e Tecnológico (EBTT) no ano de 2013, no Instituto Federal de Brasília (IFB) e pôde, então, conhecer e vivenciar o trabalho em uma instituição recém-criada e com uma característica institucional bastante específica: a integração e verticalização da educação básica à educação profissional e superior. Dessa maneira, propomos como objeto de investigação o trabalho docente na verticalização da educação profissional, técnica e tecnológica do Instituto Federal de Brasília.

A partir do ano de 2008, observa-se a alteração e expansão da Educação Profissional e Tecnológica (EPT) em todo o país apoiada na transformação das antigas Escolas Técnicas Federais. Essas escolas, a exemplo dos Centros Federais de Educação Tecnológica (CEFET), escolas agrotécnicas e escolas vinculadas a universidades, em sua maioria deixaram de existir para se transformarem em Institutos Federais de Educação, Ciência e Tecnologia, também conhecidos somente como Institutos Federais (IFs). Essa transformação significou a expansão ${ }^{1}$ da educação profissional, uma vez que as escolas técnicas federais, muitas delas centenárias, tiveram a sua estrutura administrativa reorganizada, transformadas em IFs e novas unidades descentralizadas, chamadas de campus, foram criadas em todos os estados brasileiros, contemplando regiões onde antes não havia educação básica profissional e de nível superior, pública, gratuita e federal.

Todas essas mudanças foram resultado de processos políticos, econômicos, históricos e sociais, culminados na Lei $\mathrm{n}^{\mathrm{o}} 11.892$, de 29 de dezembro de 2008, que

\footnotetext{
${ }^{1}$ No período de 1909 a 2002 havia 140 escolas técnicas federais no Brasil. Entre 2003 a 2014 foram adicionadas 214 escolas a esse número, além de outras escolas que foram federalizadas. Atualmente há 644 unidades em atividade no país formando a Rede Federal de Educação Profissional, Científica e Tecnológica. A Rede Federal conta, além dos 38 Institutos Federais, com outras escolas que não aderiram ao modelo de IF, tais como dois CEFETs, 25 escolas vinculadas a Universidades, o Colégio Pedro II e uma Universidade Tecnológica.
} 
instituiu a Rede Federal de Educação Profissional, Científica e Tecnológica (RFEPCT), conhecida como Rede Federal e criou os Institutos Federais de Educação, Ciência e Tecnologia.

Os Institutos Federais são autarquias, detentoras de autonomia administrativa, patrimonial, financeira, didático-pedagógica e disciplinar. São instituições voltadas para a educação profissional e tecnológica em nível médio e superior, sendo assim, estabelecimentos de ensino que oferecem dois níveis distintos da educação escolar: educação superior e a terceira e última etapa da educação básica, o ensino médio. Há ainda que se considerar que os Institutos Federais atuam nas modalidades de educação de jovens e adultos (EJA), educação profissional, educação especial inclusiva e educação a distância $(\mathrm{EaD})$ tornando, dessa forma, os IFs em instituições educacionais pluricurriculares.

Conforme a referida lei de criação dos IFs na Seção II, em seu Artigo $6^{\circ}$ que trata das suas finalidades e características destacamos o inciso III:

promover a integração e a verticalização da educação básica à educação profissional e educação superior, otimizando a infraestrutura física, os quadros de pessoal e os recursos de gestão (BRASIL, 2008).

Assim, verticalização é característica dos IFs que possibilitaria a integração educacional pela via da otimização dos seus recursos, inclusive humanos.

O conceito de otimização pode ser encontrado no dicionário ${ }^{2}$ da língua portuguesa, significando tornar ótimo. "Ótimo" é o adjetivo superlativo absoluto sintético de "bom", ou seja, o melhor possível. No campo da biologia significa o ponto onde se obtém melhor resposta a um estímulo ou conjunto de condições de modo que sejam as mais favoráveis à realização de diversas funções, ou seja, obter o melhor desempenho possível de um sistema, segundo critérios de funcionamento previamente definidos. No caso dos IFs, o conceito de otimização foi aplicado à educação, no qual os critérios de desempenho são a realização dos seus múltiplos objetivos, finalidades e características, em conformidade com a sua lei de criação.

A concepção de integração e verticalização, pensada por aqueles que propuseram a criação dos IFs, se insere na sua proposta curricular

\footnotetext{
${ }^{2}$ http://michaelis.uol.com.br/
} 
que integra o ensino médio à formação técnica (entendendo-se essa integração em novos moldes). Essa proposta, além de estabelecer o diálogo entre os conhecimentos científicos, tecnológicos, sociais e humanísticos e os conhecimentos e habilidades relacionados ao trabalho, além de superar o conceito da escola dual e fragmentada, pode representar, em essência, a quebra da hierarquização de saberes e colaborar, de forma efetiva, para a educação brasileira como um todo, no desafio de construir uma nova identidade para essa última etapa da educação básica. (PACHECO, 2011, p.26)

Sendo assim, além da atuação docente em diferentes níveis de ensino, os discentes também compartilhariam de "espaços de aprendizagem, incluindo os laboratórios, possibilitando o delineamento de trajetórias de formação que podem ir do curso técnico ao doutorado" (Idem, p.14) constituindo um itinerário formativo. De acordo com Silva,

a denominação instituições de educação superior, básica e profissional confere aos Institutos Federais uma natureza singular, na medida não ser comum no sistema educacional brasileiro atribuir a uma única instituição a atuação em mais de um nível de ensino. (SILVA, 2009, p.22).

Por essa característica de verticalização, os professores dos Institutos Federais defrontam-se em seu trabalho com as distintas especificidades que envolvem a integração de níveis e modalidades que perpassam o ensino, a pesquisa e a extensão na educação básica, na educação superior e tecnológica. A exigência da tríade ensinopesquisa-extensão vem pela equiparação dos Institutos Federais às universidades federais no que diz respeito aos efeitos da incidência das disposições que regem a regulação, avaliação e supervisão das instituições e dos cursos de educação superior, conforme Art. $2^{\circ}$ da sua lei de criação.

Isso significa que uma mesma instituição abrigará mais de um nível e modalidade de ensino não apenas concomitantemente, mas também de maneira integrada, ou seja, a partir de um currículo que organize cada campus em torno de um eixo tecnológico. A organização em eixos tecnológicos ${ }^{3}$ da oferta da educação profissional substitui o antigo modelo das áreas profissionais. Esses eixos são

\footnotetext{
${ }^{3}$ Ambiente, Saúde e Segurança; Controle e Processos Industriais; Gestão e Negócios; Hospitalidade e Lazer; Informação e Comunicação; Infraestrutura; Produção Alimentícia; Produção Cultural e Design; Produção Industrial; Recursos Naturais.
} 
transversais (BRASIL, 2008b) e estruturam o currículo que compatibiliza os cursos oferecidos, conferindo uma diretriz para os respectivos projetos pedagógicos.

A mesma legislação que criou os Institutos Federais informa ainda que essas instituições irão ministrar cursos de formação inicial e continuada (FIC), realizar pesquisa aplicada, ministrar em nível de educação superior cursos de licenciatura ${ }^{4}$, cursos superiores de tecnologia, programas especiais de formação pedagógica, cursos de bacharelado e engenharia, cursos de pós-graduação lato sensu, cursos de pós-graduação stricto sensu de mestrado e doutorado, dentre outros. Sendo assim, os Institutos Federais não podem ser definidos como escolas técnicas, tampouco são universidades, os IFs "representam uma nova institucionalidade na oferta da educação profissional no Brasil" (ORTIGARA, 2013, p. 2), institucionalidade essa que é diferenciada e dedicada a promover a integração e a verticalização da educação básica à educação profissional, além de pesquisa e extensão, em um mesmo campus, com um mesmo corpo docente.

Essas são características da verticalização, que por um lado oferece aos estudantes dos IFs a possibilidade de traçar um itinerário formativo que vai da educação básica ao nível superior e por outro leva o corpo docente a realizar ensino, pesquisa e extensão em diferentes níveis e modalidades simultaneamente. Tais atributos dos IFs nos levam a entender que há implicações para o trabalho docente, objeto, portanto, de nossa investigação.

Se, portanto, a natureza dos Institutos Federais é a da verticalização do ensino, os professores dessa instituição se veem diante da incumbência de verticalizar o seu trabalho, seus conhecimentos e a maneira como irão desenvolver sua atividade docente. Fica evidenciado um trabalho que está perante uma nova institucionalidade e de uma nova forma de organização curricular e de um novo espaço educativo, com múltiplas possibilidades e que se propõe a receber um público tão diverso quanto a sua oferta.

A educação profissional, técnica e tecnológica, como atual política efetivada nos Institutos Federais têm nos professores aqueles que materializam o ensino, a pesquisa e a extensão por meio do seu trabalho. As condições objetivas, entendidas como as condições efetivas de trabalho (BASSO, 1998) na verticalização são resultados de uma nova institucionalidade e organização educacional que nos propomos a conhecer e analisar criticamente.

\footnotetext{
${ }^{4}$ No desenvolvimento da sua ação acadêmica, o Instituto Federal, em cada exercício, deverá garantir o mínimo de 50\% de suas vagas para atender o nível médio e o mínimo de $20 \%$ de suas vagas para atender o nível de educação superior.
} 
Compreender o trabalho dos professores e professoras no contexto dessa nova instituição é apreender as totalidades que envolvem as características próprias do trabalho docente, a historicidade e a política de expansão da educação profissional que resultou na reorganização de antigas escolas federais, na criação dessas recentes instituições educacionais e os encadeamentos resultantes da verticalização no trabalho dos docentes que atuam no ensino profissional e superior.

O trabalho docente, no recorte específico desta pesquisa que foi realizada no Instituto Federal de Brasília e é permeado por mediações, mas não seria possível estudálo sem considerar as contradições entre a verticalização e o trabalho docente e as relações entre as totalidades que o constituem, os limites e as possibilidades da verticalização como política de otimização e integração educacional.

O Instituto Federal de Brasília faz parte dos IFs criados a partir de Escolas Agrotécnicas, mais especificamente, mediante transformação da Escola Técnica Federal de Brasília. A origem dessa escola é anterior inclusive à inauguração de Brasília, tendo sido feita pelo então presidente da República, Juscelino Kubitschek de Oliveira em 1959. Na época a escola tinha a denominação de Escola Agrotécnica de Brasília, localizada em Planaltina- DF. A escola era subordinada à Superintendência do Ensino Agrícola e Veterinário do Ministério da Agricultura, tendo como objetivo ministrar os cursos regulares dos antigos Ginasial e Colegial Agrícola. Em 1967, por meio do Decreto n ${ }^{\circ}$ 60.731, as Escolas Agrícolas vinculadas ao Ministério da Agricultura passam a ficar sob a responsabilidade do Ministério da Educação e da Cultura.

Na década de 1970, o Colégio Agrícola de Brasília foi transferido para o Governo do Distrito Federal (GDF) por meio do Decreto $n^{\circ} 82.711 / 1978$. A então Fundação Educacional do Distrito Federal (FEDF) - hoje Secretaria de Estado de Educação do Distrito Federal (SEEDF) - passou a ser responsável pelo colégio.

A partir da Portaria $n^{\circ} 129$ de 18 de julho de 2000, o Colégio Agrícola de Brasília passou a denominar-se Centro de Educação Profissional - Colégio Agrícola de Brasília (CEP/CAB), cujo funcionamento tinha como objetivo a qualificação e requalificação profissional, objetivando a realização de Cursos de Formação Inicial e Continuada de Trabalhadores e Cursos de Educação Profissional Técnica de Nível Médio, direcionados à demanda mercadológica, principalmente na sua área de abrangência. A transformação do CEP/CAB em Escola Técnica Federal de Brasília acontece em outubro de 2007, por meio da Lei ${ }^{\circ} 11.534$. 
Em 29 de dezembro de 2008, visando atender ao plano federal de educação técnica e tecnológica na implantação de um novo modelo de instituição de educação profissional, é criado, por intermédio da Lei $\mathrm{n}^{\circ}$. 11.892, como entidade de natureza autárquica, vinculada ao Ministério da Educação o Instituto Federal de Educação, Ciência e Tecnologia de Brasília composto no momento por dez campi.

Atualmente, o campus Planaltina integra juntamente com outros nove $\mathrm{e}^{5}$ campi o Instituto Federal de Educação, Ciência e Tecnologia de Brasília, cidade na qual a educação profissional federal foi pouco expressiva, sendo o único representante do gênero no DF a Escola Agrotécnica de Brasília, que ainda assim ficou durante trinta anos sob a responsabilidade do GDF. Sendo assim, dos dez campi que atualmente compõem o IFB, nove são totalmente novos, sem histórico prévio de educação superior, profissional, técnica e tecnológica.

A educação profissional, técnica e tecnológica vem ganhando espaço e importância em todo o país a partir de programas como o Proeja e o Pronatec $^{6}$ e a criação dos Institutos Federais. Diante desse cenário, colocamos a seguinte questão central da pesquisa: quais os elementos constituidores do trabalho docente na verticalização do Instituto Federal de Brasília?

Dessa forma, temos como objetivo geral desta pesquisa:

- Analisar o trabalho docente no âmbito da verticalização da educação profissional e tecnológica do IFB.

E os objetivos específicos:

- Analisar o princípio da verticalização no contexto das políticas públicas de EPT.

- Identificar quais elementos constituem o trabalho docente na verticalização da EPT no IFB.

\footnotetext{
5 Campus Brasília (inaugurado em 2009), Campus Taguatinga (inaugurado em 2009), Campus Samambaia (inaugurado em 2010), Campus Gama (inaugurado em 2010), Campus São Sebastião (inaugurado em 2011), Campus Riacho Fundo (inaugurado em 2011), Campus Estrutural (inaugurado em 2012), Campus Taguatinga Centro (inaugurado em 2012), Campus Ceilândia (inaugurado em 2013).

${ }^{6}$ Programa Nacional de Integração da Educação Profissional com a Educação Básica na Modalidade de Educação de Jovens e Adultos (Proeja) e Programa Nacional de Acesso ao Ensino Técnico e Emprego (Pronatec).
} 
- Analisar a relação entre os estruturantes do trabalho docente e as características na verticalização da EPT no IFB.

Com essa intenção, apresentamos o estado do conhecimento referente ao trabalho docente no contexto da verticalização nos Institutos Federais a partir do levantamento de estudos acerca da temática que resultou em teses, dissertações, artigos e trabalhos científicos que tratam da verticalização, do trabalho docente e da política que criou os IFs sob diversos pontos de vista e abordagens teóricas, contribuindo para a construção desta investigação.

O método crítico-dialético (GAMBOA, 2012) é a lente pela qual esta pesquisa buscou a compreensão da realidade, que se entende como contraditória e em permanente transformação (FRIGOTTO, 1999) e para isso se propõe a conceber o objeto como processo histórico concreto. A historicidade do objeto nesta pesquisa devese ao fato de que todo fenômeno da educação torna-se também histórico e, por abordar um fenômeno histórico e social, não pode prescindir da existência do real: tempo, espaço, movimento (GAMBOA, 1998).

Os procedimentos metodológicos presentes nesta pesquisa envolvem o estado do conhecimento, a revisão de literatura e análise documental a respeito do objeto. Foram aplicados questionários aos docentes do Instituto Federal de Brasília e, posterior à análise das respostas, foram selecionados professores com perfis distintos para entrevistas. Esses componentes auxiliaram na identificação e caracterização dos elementos estruturantes do trabalho docente na verticalização da educação profissional, técnica e tecnológica do Instituto Federal de Brasília.

A partir das questões relacionadas e do quadro apresentado sobre a educação profissional, técnica e tecnológica desenvolvida nos IFs e o trabalho docente, seguimos para a perspectiva metodológica de compreensão e análise dessa realidade.

\section{Abordagem metodológica}

Esta pesquisa em Educação busca compreender o trabalho docente imerso na verticalização dos Institutos Federais como parte integrante de uma política pública educacional mais ampla de expansão da educação profissional e superior. Para este 
propósito, o método crítico-dialético é o caminho eleito para a construção do conhecimento. A elaboração do conhecimento a partir da abordagem crítica-dialética

reconhece a ciência como produto da história, da ação do próprio homem, que está inserido no movimento das formações sociais. Nesse sentido, encara a ciência como uma construção decorrente da relação dialética entre o pesquisador e objeto envolvidos em determinada realidade histórica (SOUSA, 2014, p. 2).

Isto posto, a apreensão do objeto pela pesquisadora afilia-se à perspectiva materialista histórica dialética como opção epistemológica, teórica, metodológica e política, pois ao contrário das aparências, a educação profissional "nunca esteve tanto na ordem do dia [...] exatamente porque nossa sociedade continua sendo regida pelos ditames do capital” (ANTONIAZZI, 2012, p. 128). Faz-se necessário, portanto, assumir o compromisso da não neutralidade da produção da pesquisa científica, especialmente no campo da Educação, uma vez que há implicação do sujeito pesquisador no objeto. Consequentemente, não é possível falar em neutralidade, mas sim em "objetividade do conhecimento teórico" (NETTO, 2011, p. 23).

Nas Ciências Humanas e na Educação, o materialismo histórico dialético parece ser a perspectiva mais condizente, pois "as leis e categorias da dialética materialista desenvolvem o conhecimento tendo por fundamento a concreticidade e a multiformidade dos fenômenos, dos processos e dos objetos, para interpretar a realidade objetiva" (BREZINSKI, 2013, p. 342) e, assim, apreender o movimento do real e as transformações do fenômeno educativo na educação superior, profissional e tecnológica.

Esta investigação se propõe a realizar uma análise concreta do trabalho docente na verticalização promovida pelos IFs, especificamente no Instituto Federal de Brasília. A visão crítica sobre o trabalho docente na verticalização não tem como objetivo afirmá-la como "boa" ou "má", mas sim, como propõe Netto

em Marx, a crítica do conhecimento acumulado consiste em trazer ao exame racional, tornando-os conscientes, os seus fundamentos, os seus condicionamentos e os seus limites - ao mesmo tempo em que se faz a verificação dos conteúdos desse conhecimento a partir dos processos históricos reais (NETTO, op. cit., p. 18).

Dessa maneira, pretendemos colocar o trabalho docente na EPT e a verticalização numa perspectiva histórica na construção de uma política pública 
educacional de educação profissional no Brasil, que culminou na criação dos IFs e que vem se constituindo nos últimos oito anos aparentemente como uma inovação no campo educacional.

A análise de uma política educacional compreende as formas jurídicas que as legitimam, tais como leis e decretos, assim como as múltiplas mediações geradas a partir da "sua relação com um projeto sociopolítico, no contexto de um Estado representado por um projeto de governo" (TORRIGLIA; ORTIGARA, 2014, p.195). Assim, a pesquisa buscou analisar alguns aspectos que constituem esta política, aqui especificamente sob o olhar do trabalhador docente, aquele que vive e objetiva o processo educativo.

Sendo assim, a compreensão do trabalho docente no contexto da verticalização dos Institutos Federais nas suas várias dimensões deve considerar sua historicidade, desvelando as contradições e as mediações no contexto da totalidade na qual ele se manifesta. Para esse propósito são elencadas as categorias da totalidade, contradição e mediação, que são categorias próprias do método crítico-dialético a partir das quais é possível investigar o objeto em sua totalidade concreta.

A totalidade é entendida em Lukács como um complexo de complexos (LESSA, 1996), ou seja, "um todo estruturado em desenvolvimento" (MASSON, 2012, p. 12), e para captar a totalidade do trabalho docente buscaremos apreender as relações e contradições da atual política de expansão de educação da classe trabalhadora por meio dos IFs. A educação, ao mesmo tempo em que está inserida na realidade social, "é contraditória em seus vários elementos" (CURY, 1987, p. 70), expressando os conflitos em seu interior, assim, a contradição é o motor interno do movimento expressando as relações de conflito entre seus contrários. Dessa forma, buscamos compreender as mediações, ou seja, as relações concretas que vinculam a passagem entre dois momentos do desenvolvimento e do movimento de forma a entender qual é a lógica articuladora dessas totalidades e as determinações na maneira como a legislação e as políticas se vinculam ao trabalho docente na verticalização.

Sendo assim, os eixos de análise da pesquisa envolvem o trabalho docente, a política pública para educação profissional, a verticalização e as condições concretas de trabalho.

O trabalho docente deve ser analisado na totalidade da categoria trabalho e em sua especificidade, pois tem aspectos próprios, principalmente levando em consideração o contexto no qual ele acontece que é o da verticalização. A verticalização entra na 
pesquisa como uma característica dos Institutos Federais e que, sendo proveniente de uma política pública que busca promover a integração da educação básica à educação profissional e superior, otimizando a infraestrutura física, os quadros de pessoal e os recursos de gestão, propõe um modelo de instituição de gênero único no país.

As condições concretas de trabalho dos professores e professoras dos IFs são resultados dessa política de expansão acelerada pela qual a educação profissional tem passado nos últimos anos e, junto com a política de expansão e a nova institucionalidade verticalizada dos Institutos Federais, compõem eixos de análise que buscam mediar as suas relações universais e concretas que indicam levar a intensificação do trabalho docente. A intensificação envolve as mudanças provenientes das recentes reformas educacionais que levam a "[...] demanda por aumento de produtividade, a invasão do espaço doméstico pelo trabalho, o maior controle externo de resultados, dentre outros" (FIDALGO, N., FIDALGO, F., 2009, p. 96).

As categorias são recortes particulares da investigação e a relação que cada um deles mantém entre si busca entender quais são as mediações para compreender a totalidade do trabalho docente em uma conjuntura mais ampla. Como resultado, nos propomos a conhecer a lógica articuladora do todo para sobre este agir intencionalmente e coletivamente.

\section{Instrumentos e técnicas de pesquisa}

Para alcançar os objetivos propostos nesta investigação foram utilizados instrumentos e técnicas de pesquisa que auxiliaram na compreensão do objeto. Em um primeiro momento, a pesquisa teve caráter exploratório com a finalidade de proporcionar mais familiaridade com o tema do trabalho docente na verticalização dos Institutos Federais, com vistas a torná-lo mais explícito, além de evidenciar as principais ideias já discutidas por outros autores que trataram do problema, levantando críticas e dúvidas (GERHARDT; SILVEIRA, 2009). Esta etapa compreendeu o estado do conhecimento e a pesquisa bibliográfica.

A coleta de dados foi complementada por pesquisa documental a partir da legislação educacional voltada para a EPT, bem como documentos oficiais emitidos pelo Ministério da Educação (MEC) e Secretaria de Educação Profissional e Tecnológica (SETEC) e pelo próprio IFB. Os documentos oficiais e a legislação são 
representantes do discurso oficial de sustentação do modelo de Instituto Federal. Compreendendo que esses textos fazem parte de uma política de educação e

partindo do suposto da política como processo, uma contribuição interessante para a análise desses documentos parece decorrer da exploração das contradições internas às formulações, posto que os textos evidenciam vozes discordantes, em disputa (SHIROMA; CAMPOS; GARCIA, 2005, p. 431).

Em um segundo momento, foi aplicado questionário para os professores de nove campi que compõem o Instituto Federal de Brasília, contemplando questões a respeito do trabalho docente. No segundo semestre de 2015 foi aplicado um questionário piloto para 10 professores de três diferentes campi do IFB com o objetivo de realizar um préteste do instrumento.

O questionário foi o instrumento utilizado para conhecer o perfil do professor do Instituto Federal de Brasília, sua formação acadêmica, sua forma de atuação profissional, os aspectos sociais e culturais, o perfil político, as condições materiais de trabalho, da sua relação com o sindicado, sobre o conhecimento docente para atuação na verticalização, formação continuada e organização do trabalho pedagógico. É importante salientar que esse questionário faz parte de uma pesquisa mais ampla sobre a profissionalidade docente, que é financiada pelo Conselho Nacional de Desenvolvimento Científico e Tecnológico (CNPq) e por isso o instrumento conta com questões que envolvem não somente o tema do trabalho docente na verticalização.

Os sujeitos desta pesquisa foram os professores que atuam no Instituto Federal de Brasília, independente de sua relação de trabalho com o IFB - participaram da pesquisa tanto professores efetivos como substitutos ou temporários. A partir das respostas dos questionários, foi possível selecionar alguns professores com perfis variados para entrevistas com perguntas previamente estabelecidas a respeito do trabalho docente na verticalização do IFB. As respostas dos professores aos questionários e entrevistas subsidiaram a análise do objeto e compreensão de suas muitas determinações. 


\section{Estrutura e organização da dissertação}

A dissertação está estruturada em quatro capítulos. O primeiro capítulo - $O$ que dizem as pesquisas: produção acumulada sobre a verticalização no trabalho docente tem como objetivo apresentar o estado do conhecimento a partir da produção acadêmica que trata do objeto da pesquisa, ou seja, o trabalho docente na verticalização da educação profissional nos Institutos Federais.

O segundo capítulo, intitulado - Princípio da verticalização nas políticas públicas de educação profissional e tecnológica: aspectos históricos e legais - descreve os marcos históricos e as políticas públicas da educação profissional no Brasil que levaram à criação dos IFs e o princípio da verticalização.

O terceiro capítulo, denominado - Institutos Federais: trabalho docente na verticalização - identifica os elementos constituidores do trabalho docente na EPT e no contexto da verticalização, além de analisar as principais abordagens teóricas do trabalho docente.

E por fim, o quarto capítulo - Trabalho docente na verticalização: as concepções dos professores - apresenta as perspectivas dos docentes do IFB a respeito da política de verticalização, as condições de trabalho e a integração da educação proposta pelo modelo do IF, bem como analisa a relação entre os estruturantes do trabalho docente e as características na verticalização da EPT no IFB. 


\section{O QUE DIZEM AS PESQUISAS: PRODUÇÃO ACUMULADA SOBRE O TRABALHO DOCENTE NA VERTICALIZAÇÃO}

Este capítulo apresenta o estado do conhecimento a partir da produção acadêmica que trata do objeto da pesquisa, o trabalho docente na verticalização da educação profissional nos Institutos Federais. $\mathrm{O}$ estado do conhecimento que apresentamos aqui busca evidenciar e discutir o que está sendo pesquisado sobre esse tema na área da educação em geral e na educação profissional dos IFs em específico. O tema do trabalho docente na verticalização da educação profissional é bastante recente, pois teve seu início formal a partir do final do ano de 2008 com a lei de criação dos Institutos Federais e, portanto, trata-se de um assunto ainda com poucos estudos a respeito.

Esses estudos, por tratarem de uma política com menos de uma década de existência têm outra característica em comum além da parca quantidade: é o fato de serem análises iniciais sobre o tema. Por si só, esse fato sugere a necessidade de aprofundamento. Ao mesmo tempo, os trabalhos indicam tendências no âmbito dos Institutos Federais à medida que algumas categorias de análise se repetem. Ao final do capítulo, propomos algumas considerações a respeito dos estudos levantados aqui, evidenciando os caminhos que o trabalho docente na verticalização vem tomando nos Institutos Federais em todo o país.

Para este levantamento utilizamos como principal palavra-chave nos filtros de busca a "verticalização", combinada com os termos "educação profissional”, "Institutos Federais" e "trabalho docente". Essas palavras-chave se justificam pelo tema da pesquisa, ou seja, compreender a totalidade do trabalho docente no contexto da verticalização da educação profissional e tecnológica promovida pelos Institutos Federais. O recorte temporal do levantamento sobre o conhecimento produzido a respeito do trabalho docente na verticalização teve foco no intervalo de $2009^{7}$ a 2015 , por se tratar do período de efetiva atuação dos IFs.

O mapeamento sobre o objeto da pesquisa foi realizado a partir das seguintes bases de dados:

7 Apesar da lei de criação dos Institutos Federais datar de 2008, sua publicação aconteceu em dezembro daquele ano, sendo a legislação formalmente posta em prática a partir do ano de 2009. Esse marco temporal é importante, pois é na lei de criação dos IFs que consta pela primeira vez o termo "verticalização" como uma característica dos Institutos Federais. 
- $\quad$ Biblioteca Digital Brasileira de Teses e Dissertações (BDTD) do Instituto Brasileiro de Informação em Ciência e Tecnologia (IBCIT)

- $\quad$ Banco de Teses da Coordenação de Aperfeiçoamento de Pessoal de Nível Superior (CAPES)

- $\quad$ Scientific Electronic Library Online (SCIELO)

- $\quad$ Google Acadêmico

- $\quad$ Associação Nacional de Pós-graduação e Pesquisa em Educação (Anped)

- Colóquio Nacional A produção do conhecimento em Educação Profissional

A partir das palavras-chave a busca no $\mathrm{BDTD}^{8}$ apresentou 178 resultados. $\mathrm{O}$ Banco de Teses da Capes $^{9}$ apresentou 72 registros. O tema da verticalização, em ambas as bases de dados, aparece amplamente e com as mais diversas acepções nas áreas de Arquitetura e Urbanismo, Engenharia Civil, Administração, Odontologia, Geografia Urbana e Logística. Na categoria de teses e dissertações foi encontrado um total de cinco trabalhos, sendo três dissertações de mestrado e duas teses de doutorado a respeito do objeto desta pesquisa. As teses e dissertações representam o Quadro 1.

A busca sobre o tema da pesquisa no Scielo $^{10}$ resultou em 29 artigos científicos que continham as palavras-chave, seja no título ou resumo. Nenhum dos artigos apresentou o conceito de verticalização utilizado na educação profissional dos Institutos Federais. Os artigos encontrados tratam sobre a questão da verticalização nas mais variadas áreas e vão desde as Ciências da Saúde, passando pelas Ciências Sociais Aplicadas, Engenharias e Ciências Agrárias, mas não tratam da verticalização na educação.

Na ferramenta de busca Scielo integrado ao Google Acadêmico a busca pelas palavras-chave apresentou 243 ocorrências. A maior parte dessas ocorrências repetiram as temáticas dos artigos encontrados na busca inicial do Scielo. De todo o levantamento

8 A Biblioteca Digital Brasileira de Teses e Dissertações (BDTD) tem por objetivo reunir, em um só portal de busca, as teses e dissertações defendidas em todo o País e por brasileiros no exterior.

9 O Banco de Teses faz parte do Portal de Periódicos da Capes/MEC e pretende facilitar o acesso a informações sobre teses e dissertações defendidas junto a programas de pós-graduação do país.

${ }^{10}$ A Scientific Electronic Library Online (SciELO) é uma biblioteca eletrônica que abrange uma coleção selecionada de periódicos científicos brasileiros. 
três artigos refletem aproximações com o objeto da pesquisa. O Quadro 2 sintetiza os artigos científicos publicados em revistas.

Quanto aos eventos de divulgação científica, nesta busca foram contempladas as reuniões anuais da Anped $^{11}$, a partir da 32a reunião anual em 2009 até a 37 em 2015.

Já no Colóquio Nacional A Produção do Conhecimento em Educação Profissional ${ }^{12}$, foram analisados os trabalhos completos da segunda e terceira edições do evento, ocorridas em 2013 e 2015 e disponibilizados no site do evento. Na primeira edição do colóquio, em 2011, foi disponibilizada apenas a programação no site do evento. As buscas sobre a temática do trabalho docente na verticalização da educação profissional nos Institutos Federais em eventos científico-acadêmicos resultaram em três trabalhos. O Quadro 3 sintetiza os trabalhos publicados em eventos.

Dessa forma, apresentamos a seguir as produções acadêmicas que compõe o estado do conhecimento acerca do objeto da pesquisa, organizado primeiramente em quadros que sintetizam e facilitam a visualização. Cada um dos quadros está organizado de maneira cronológica. Posteriormente, realizamos uma síntese crítica em categorias a respeito das perspectivas de análise a partir do exame da produção acumulada sobre o trabalho docente na verticalização.

\footnotetext{
${ }^{11}$ ANPEd é uma associação sem fins lucrativos que congrega programas de pós-graduação stricto sensu em educação, professores e estudantes vinculados a estes programas e demais pesquisadores da área.

${ }^{12}$ Evento bianual, organizado desde 2011 pelo Programa de Pós-Graduação em Educação Profissional (PPGEP) do Instituto Federal de Educação, Ciência e Tecnologia do Rio Grande do Norte (IFRN) que se propõe a consolidar-se como espaço para produção e difusão do conhecimento acerca da Educação Profissional e de suas interrelações com a Educação Básica no Brasil.
} 
Quadro 1 - Quadro representativo de teses e dissertações relacionadas ao objeto de estudo, considerando o recorte temporal de 2009 a 2016.

\begin{tabular}{|c|c|c|}
\hline Autor/ ano & Título & $\begin{array}{c}\text { Objeto } \\
\text { Trabalho docente na verticalização }\end{array}$ \\
\hline $\begin{array}{l}\text { RAMOS, Elbo Lacerda } \\
\text { Tese de Doutorado } \\
\text { (2011) }\end{array}$ & $\begin{array}{c}\text { Consensos e dissensos em torno da alteração do } \\
\text { centro de atuação das Instituições da Rede Federal } \\
\text { de Educação Profissional, Científica e } \\
\text { Tecnológica de origem agrícola: representações } \\
\text { do trabalho docente. }\end{array}$ & $\begin{array}{l}\text { Aproxima do objeto por tratar do trabalho docente na } \\
\text { RFEPTC, a partir dos anos } 2000 \text {, quando se iniciaram as } \\
\text { primeiras implantações de cursos de graduação nas } \\
\text { escolas agrícolas federais, e trata da política de transição } \\
\text { para a criação dos IFs, a ênfase na verticalização e os } \\
\text { reflexos no trabalho e no parâmetro de desempenho de } \\
\text { professores. }\end{array}$ \\
\hline $\begin{array}{c}\text { RUFINO NETO, Joaquim. } \\
\text { Dissertação de Mestrado } \\
(2012)\end{array}$ & $\begin{array}{l}\text { A missão institucional do campus Crato do IFCE: } \\
\text { percepção da comunidade escolar sobre os } \\
\text { avanços e desafios para desenvolver o ensino, a } \\
\text { pesquisa e a extensão em um novo projeto de } \\
\text { sociedade. }\end{array}$ & $\begin{array}{l}\text { Aproxima do objeto ao tratar da transição de uma escola } \\
\text { federal de educação profissional com mais de } 40 \text { anos de } \\
\text { atuação para o modelo de IF e as implicações trazidas pela } \\
\text { verticalização para o corpo docente e discente. }\end{array}$ \\
\hline $\begin{array}{l}\text { FERNANDES, Maria Regina da } \\
\text { Silva. } \\
\text { Dissertação de Mestrado } \\
\text { (2013) }\end{array}$ & $\begin{array}{c}\text { O processo de verticalização da educação } \\
\text { profissional e tecnológica e suas implicações na } \\
\text { qualidade do trabalho dos docentes do Câmpus } \\
\text { São Vicente do Sul do Instituto Federal } \\
\text { Farroupilha. }\end{array}$ & $\begin{array}{l}\text { Aproxima-se do objeto na investigação das formas como o } \\
\text { processo de verticalização do ensino influencia no } \\
\text { trabalho docente, os reflexos mais significativos da } \\
\text { verticalização na atividade docente e na qualidade de vida } \\
\text { dos professores. }\end{array}$ \\
\hline $\begin{array}{c}\text { GONÇALVES, Sandra Lúcia } \\
\text { Dissertação Mestrado } \\
(2014)\end{array}$ & $\begin{array}{l}\text { A expansão da rede de educação profissional, } \\
\text { científica e tecnológica: implicações nas relações } \\
\text { e condições de trabalho no Instituto Federal de } \\
\text { Educação, Ciência e Tecnologia de Goiás. }\end{array}$ & $\begin{array}{l}\text { Investiga e a analisa a expansão e a reconfiguração da } \\
\text { educação profissional, científica e tecnológica e suas } \\
\text { implicações nas relações e condições de trabalho de } \\
\text { professores e técnicos no IFG. No estudo apreendeu-se o } \\
\text { processo e os nexos com a precarização e intensificação } \\
\text { do trabalho e a nova institucionalidade da rede. }\end{array}$ \\
\hline $\begin{array}{c}\text { VERDUM, Priscila de Lima } \\
\text { Tese de Doutorado } \\
(2015)\end{array}$ & $\begin{array}{l}\text { Formação inicial de professores para educação } \\
\text { básica, no contexto dos IFs: propondo indicadores } \\
\text { de qualidade, a partir de um estudo de caso no } \\
\text { IFRS. }\end{array}$ & $\begin{array}{l}\text { A aproximação com o objeto está no estudo da } \\
\text { verticalização enquanto característica institucional, no } \\
\text { ensino, nas práticas pedagógicas e na formação de } \\
\text { formadores. }\end{array}$ \\
\hline
\end{tabular}

Fonte: BDTD/IBCIT e CAPES (2016) 
Quadro 2 - Quadro representativo de artigos relacionados ao objeto de estudo, considerando o recorte temporal de 2009 a 2016.

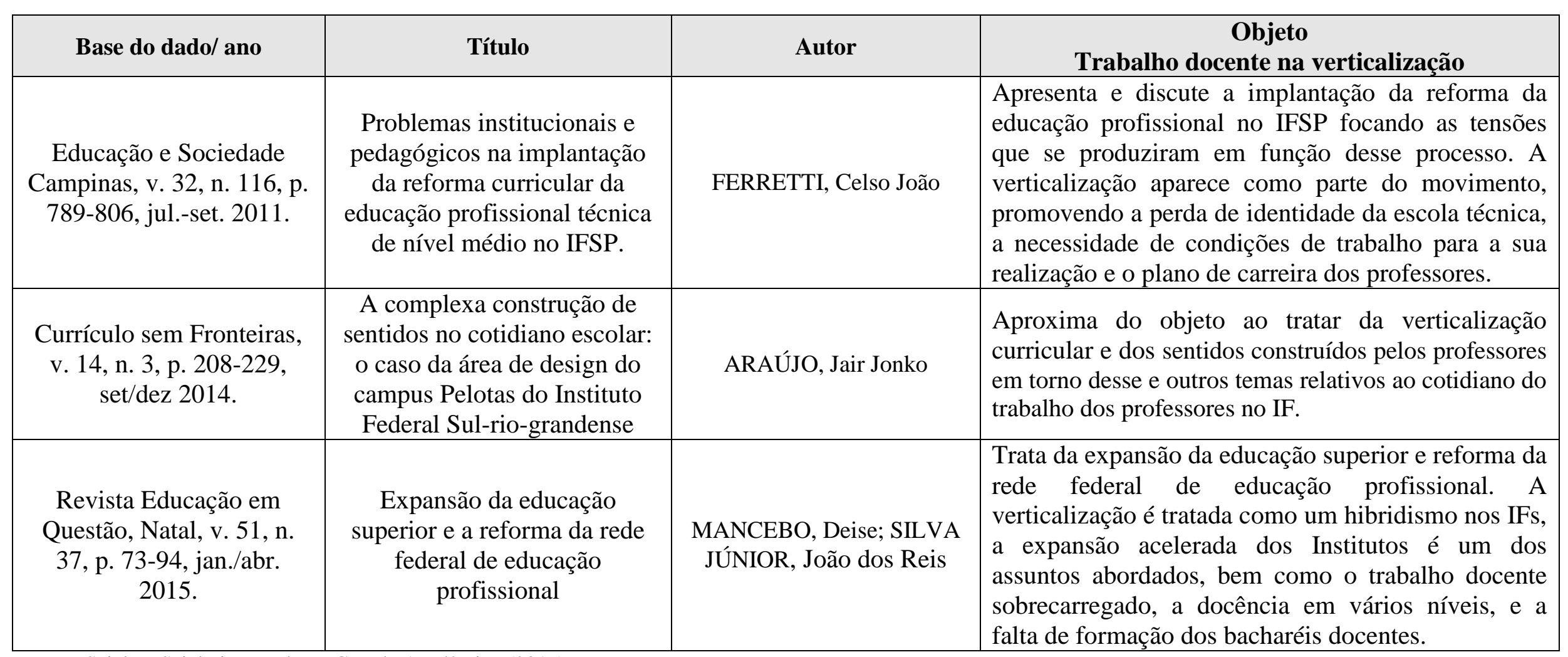

Fonte: Scielo e Scielo integrado ao Google Acadêmico (2016) 
Quadro 3 - Quadro representativo de trabalhos em eventos relacionados ao objeto de estudo, considerando o recorte temporal de 2009 a 2016.

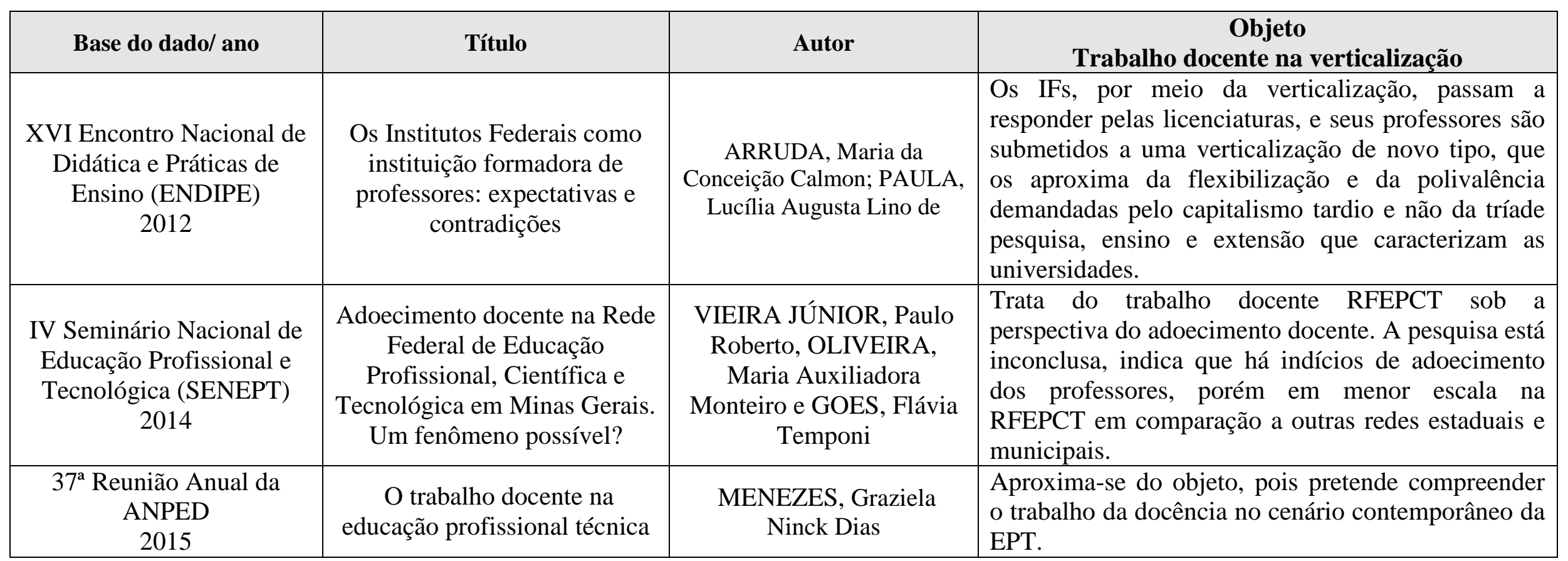

Fonte: Reuniões anuais da Anped e Colóquio Nacional A Produção do Conhecimento em Educação Profissional (2016) 
A tese de doutorado de Elbo Lacerda Ramos, intitulada "Consensos e dissensos em torno da alteração do centro de atuação das Instituições da Rede Federal de Educação Profissional, Científica e Tecnológica de origem agrícola: representações do trabalho docente" defendida no ano de 2011 trata do processo histórico de criação dos Institutos Federais, neste caso específico um IF surgido a partir de uma escola agrícola. $\mathrm{O}$ autor desenvolve sua pesquisa a partir das representações desses docentes que viveram a transição e se veem diante da nova institucionalidade criada a partir da verticalização.

Em sua tese, o autor afirma a necessidade de superação do dissenso que há na visão do ensino técnico como meramente tecnicista. O pesquisador enfatiza que a partir da transição de escolas federais para Institutos Federais, houve uma mudança quanto à questão da pesquisa científica. Os IFs passam a ser produtores de conhecimento, porém "há uma propensão a constituir um mandato que remete a uma visão puramente ancorada na perspectiva da direção 'correta' e incontroversa da ciência e tecnologia como estruturas desprovidas de ideologia e de direções humanas" (RAMOS, 2011, p. 131). Esse tipo de pesquisa, em consonância com o Estado Gerencial ${ }^{13}$, leva os professores a serem, inclusive, responsáveis pela captação de recursos para o custeio da realização de atividades formais extraclasse.

Ainda de acordo com Ramos, “os códigos reguladores procedentes da reforma da Educação Profissional, Científica e Tecnológica dos anos 1990 que permanecem e os que promovem o diferencial de verticalização da reforma dos anos 2000” (Idem, p. 133) implicam em alguns desdobramentos, dentre eles o aumento da regulação burocrática e a pouca autonomia ao docente, que acaba restrita a assuntos de pesquisa e captação de recursos, acentuando os processos de individualização. Fica evidente a cultura da eficiência interna dos Institutos Federais regulados por agentes externos.

O pesquisador finaliza enfatizando que, a partir da verticalização, há a necessidade de superar a representação compartimentada da educação profissional de nível médio, técnico e superior e "criar um ambiente onde o trabalho docente seja valorizado pela própria essência do trabalho docente" (Idem, p. 137), ou seja, um trabalho autônomo.

\footnotetext{
${ }^{13}$ A administração gerencial empreende adequar as organizações públicas aos seus objetivos prioritários, que são os resultados. Busca identificação com os usuários e incrementar sua eficiência com mecanismos de quase-mercado ou concorrência administrada. Cadernos do MARE da Reforma do Estado - Vol. 11- A Nova Política de Recursos Humanos. Brasília, MARE, 1997. P.8. http://www.ambitojuridico.com.br/site/index.php?n_link=revista_artigos_leitura\&artigo_id=503 acessado em 6/9/2016.
} 
A segunda tese de doutorado analisada é a de Priscila de Lima Verdum, com o título "Formação inicial de professores para educação básica, no contexto dos IFs: propondo indicadores de qualidade, a partir de um estudo de caso no IFRS" defendida em 2015. Nesta tese a verticalização é explorada como característica dos IFs que devem destinar $20 \%$ das suas vagas para os cursos de licenciatura. A autora destaca o fato dos Institutos Federais terem pouca ou nenhuma experiência na formação de professores, e defende a tese de que os

IFs com estrutura verticalizada de ensino, aliada à tríade ensino, pesquisa e extensão, podem ser um meio profícuo para a formação dos docentes, se concebidas e planejadas ações estratégicas que considerem as características das suas licenciaturas e do seu contexto institucional. (VERDUM, 2015, p.7).

A característica da verticalização do ensino foi enfatizada positivamente pela pesquisadora, tendo em vista seu potencial para proporcionar processos de formação docente inovadores e com "qualidade". Nessa pesquisa, a verticalização é tratada como um desafio aos IFs, pois esse modelo de instituição representa um "largo espectro de atuação (atuação em diferentes níveis, necessidade de elaborar e articular diferentes planos pedagógicos), e envolvimento em diferentes programas" (Idem, p. 210).

A autora realizou entrevistas com os gestores do IFRS, os quais afirmaram que os professores que atuam nas licenciaturas daquele campus apresentam dificuldades em seu trabalho, tais como o excesso de carga horária, o que dificulta o planejamento coletivo. Uma solução apontada para essa questão seria formalizar o horário de planejamento coletivo como parte integrante da carga horária docente. Um dos "desafios" apontados pelos entrevistados foi a necessidade de valorização da carreira docente no contexto da instituição.

Sobre as três dissertações de mestrado encontradas, a primeira a ser analisada é a de Joaquim Rufino Neto, com o título "A missão institucional do campus Crato do IFCE: percepção da comunidade escolar sobre os avanços e desafios para desenvolver o ensino, a pesquisa e a extensão em um novo projeto de sociedade", defendida em 2012 e que trata do papel das escolas técnicas federais e a sua transição para o modelo dos Institutos Federais a partir do estudo de caso do campus Crato. O campus em questão tinha "mais de 40 anos" de experiência no ensino profissional quando iniciou o chamado processo de "ifetização" em 2010 e a instituição teve a "incumbência de desenvolver pesquisa e extensão, em similaridade com as universidades" (RUFINO 
NETO, 2012, p. 2). Diante disso, o autor se propõe a pesquisar os "principais desafios e avanços que o campus Crato enfrentou/alcançou para realizar estas atividades, sob a perspectiva de docentes e discentes" (Ibidem, p. 17).

O autor compara ao longo da pesquisa o discurso oficial sobre o que se espera das atribuições e características dos IFs, entre elas a verticalização do ensino, a pesquisa aplicada e a extensão e o que, de fato o campus desenvolve dentro dos seus avanços e dificuldades. A investigação se deu levando em consideração o início dos cursos de nível superior, o que provocou grandes mudanças em uma instituição que era focada somente no ensino técnico. A pesquisa contou com a participação de docentes e discentes para levantar as concepções sobre ensino, pesquisa e extensão.

Sobre a transição das escolas técnicas federais para o modelo de Instituto Federal, o pesquisador define o processo final de discussões junto ao MEC e a SETEC em meados do ano 2007 da seguinte maneira

\footnotetext{
Assim sendo, o longo debate para a constituição dos IFET's relegou aos grupos de trabalho um papel que sequer pode ser comparado ao de coadjuvante, pois, os mesmos eram "meros instrumentos ouvidores" das determinações impostas pelo governo, não havendo clareza de quem realmente era o protagonista do projeto de expansão da Rede Federal de Ensino (RUFINO NETO, 2012, p. 12).
}

O turbulento caminho para criação dos Institutos Federais resultou na Lei 11.892 de 29 de dezembro de 2008 que promoveu um "novo arranjo" da educação profissional, implicando na pouca participação da comunidade educacional no processo.

O autor destaca o caráter "multifuncional" dos IFs, ou seja, em um curto espaço de tempo, em função da verticalização, a instituição passou a receber um público muito diverso, enfatizando que a verticalização "supõe que um mesmo profissional (o docente) pode atender todas estas demandas e públicos diferenciados" (Idem, p. 18). O autor questiona essa possibilidade e se os docentes estariam realmente preparados para tal, visto que o recém-criado IF agora tinha um acúmulo de diversas novas atribuições.

O pesquisador conclui afirmando que os desafios para a efetivação do projeto de Instituto Federal são enormes, tanto pela falta de recursos humanos e materiais, quanto pelo processo acelerado e pela falta de clareza "das consequências de aderir às propostas dos documentos oficiais como estão postos" (Idem, p. 53). O autor indica que os IFs podem se limitar a cumprir demandas ou realizar pseudo ensino, pesquisa e extensão apenas para dar respostas superficiais às diretrizes que foram impostas. Rufino 
Neto assevera que, a partir dessa nova institucionalidade não há uma identidade própria para as escolas. Os IFs não se reconhecem como escolas técnicas, nem como centros de ciência e tecnologia, nem universidades. $\mathrm{O}$ autor finaliza dizendo que não se pode aceitar que os IFs sejam modelos de universidade de menor custo e reféns das demandas de mercado.

A dissertação de mestrado de Maria Regina da Silva Fernandes com o título "O processo de verticalização da educação profissional e tecnológica e suas implicações na qualidade do trabalho dos docentes do Câmpus São Vicente do Sul do Instituto Federal Farroupilha", foi defendida em 2013 e trata da verticalização nos Institutos Federais e as implicações para o trabalho docente. Segundo a pesquisadora "a verticalização pode exercer influências decisivas nos métodos e técnicas de ensino, na construção e desenvolvimento dos currículos" (FERNANDES, 2013, p. 28).

A partir de um resgate histórico, a autora relembra que a verticalização teve início nos CEFETs com a gradual oferta de cursos de nível superior

A verticalização iniciada no modelo CEFET, que ainda hoje mantém ativa muitas de suas determinações, não consistia tão somente na justaposição de graus de formação e níveis de ensino, mas pretendia favorecer um intercâmbio de professores que atuavam num mesmo departamento, porém ministrando aulas para os ensinos médio e superior (FERNANDES, 2013, p. 29).

De acordo com a pesquisadora, em termos de organização curricular, a verticalização, prevê a interação entre vários níveis de ensino e o diálogo entre os conhecimentos científicos e o trabalho. Sua proposta é a de superação da escola dual e fragmentada e busca uma nova identidade para o ensino médio, última etapa da educação básica. A autora enfatiza que a verticalização não envolve apenas o ensino, visto que a pesquisa e a extensão também devem acontecer em todos os níveis oferecidos pelos IFs.

A autora afirma que o trabalho dos docentes também foi verticalizado a partir da criação dos Institutos Federais. Cada campus teve de distribuir a carga horária entre os docentes, de forma que todos atuem em níveis e modalidades diferentes e afirma que

Diante dessa pressão, o docente acaba realizando uma atividade fragmentada e, com isso, não consegue cumprir tantas e diferentes tarefas de forma simultânea, o que implica em alienação, privações de convívio, problemas sociais, angústia e auto cobrança constante. (FERNANDES, 2013, p. 43). 
De acordo com Fernandes, muitos professores prestam o concurso para os Institutos Federais sem estarem preparados para a realidade que irão enfrentar, muitas vezes não tendo experiência nem formação para atuar nos diversos níveis, nem na pesquisa, nem na extensão. A partir da aplicação de questionários no campus São Vicente do Sul do Instituto Federal Farroupilha e análise documental, a autora afirma que a maior dificuldade para que os professores realizem o trabalho verticalizado é a falta de formação oferecida pela própria instituição. Os professores afirmaram ter dificuldades em lidar com diferentes metodologias didáticas para públicos tão distintos e a adequação do conteúdo para cada um dos níveis. A autora sugere que a instituição adote medidas para "minimizar os possíveis problemas detectados" como, por exemplo, debater a verticalização nas reuniões pedagógicas bem como "revisão dos métodos de ensino, com a finalidade de proporcionar o aprendizado de novas práticas, mais dinâmicas e eficazes no cenário da verticalização" (Ibidem, 2013, p. 68). A autora finaliza enfatizando a necessidade da formação do professor com destaque para ações e reflexões sobre a prática.

A dissertação de mestrado de Sandra Lúcia Gonçalves intitulada “A expansão da rede de educação profissional, científica e tecnológica: implicações nas relações e condições de trabalho no Instituto Federal de Educação, Ciência e Tecnologia de Goiás" defendida em 2014 se apoia na perspectiva da relação capital, trabalho e educação à luz de categorias e conceitos desenvolvidos por Marx e Engels, abordando as principais mediações que contribuíram para a constituição de uma estreita relação entre educação profissional e o modo de produção capitalista. Além disso, foram realizadas pesquisas documentais e questionários aplicados aos gestores, dirigentes e trabalhadores docentes e técnicos administrativos. Segundo a autora, o critério de inclusão dos trabalhadores técnico administrativos justifica-se pela relevância dessa categoria na gestão do sistema educacional e a inexistência de pesquisas sobre as relações e condições de trabalho desse segmento. As perguntas do questionário tinham como proposta evidenciar as implicações advindas da expansão e reestruturação da rede nas relações e condições de trabalho no Instituto Federal de Goiás (IFG).

A autora analisa a expansão e a reconfiguração da educação profissional no Brasil e as implicações nas relações e condições de trabalho no IFG. Gonçalves afirma que há semelhanças entre o trabalho que os docentes desenvolvem no Instituto com o trabalho realizado pelos docentes universitários, porém, os docentes dos IF têm a pressão das demandas do mercado e o estímulo à pesquisa aplicada. 
A pesquisadora destaca a questão da dificuldade em fixar os trabalhadores docentes em campus menores e interioranos do IFG, resultando na desistência de alguns professores em atuar em determinadas localidades, uma vez que estes parecem preferir trabalhar nos grandes centros urbanos. O processo de interiorização dos IFs também faz com que haja dificuldade em conseguir professores qualificados nessas regiões. A pesquisa de campo de Gonçalves indicou que há "indícios de democratização da educação no país, viabilizando o acesso de maior número de brasileiros à educação profissional e tecnológica" (GONÇALVES, 2014, p. 139) e que essa mesma expansão trouxe "insuficiência de recursos humanos, de infraestrutura, laboratórios insalubres e sucateados, número insuficiente de salas de aula e de materiais, de equipamentos, falta de planejamento, acúmulo de tarefas, comprometimento da qualidade do ensino, centralização da gestão, tecnocratismo, parceria público e privado (terceirizações e Pronatec), dentre outros” (Idem, p. 139). Acrescentado a isso há a questão do déficit de professores no IFG, respaldado por relatório do Tribunal de Contas da União (TCU) citado pela autora, o que causa sobrecarga nos docentes que estão em exercício, levando-os à intensificação do seu trabalho.

A autora conclui a pesquisa enfatizando que a política de expansão da educação profissional no Brasil, atendendo às diretrizes de organismos internacionais "têm impactado não só na relação público e privado, mas também a natureza e as relações de trabalho daqueles que atuam nessa modalidade de educação” (Idem, p. 176).

Sobre os três artigos encontrados durante a pesquisa pelas palavras-chave, iniciaremos pelo artigo de Celso João Ferretti intitulado "Problemas institucionais e pedagógicos na implantação da reforma curricular da educação profissional técnica de nível médio no IFSP” publicado em 2011 e que trata da reforma curricular na educação profissional e questiona a possibilidade dos IFs realizarem a educação politécnica na perspectiva marxiana.

O autor inicia o trabalho pautando a criação dos IFs nos discursos oficiais e no destaque que o Ensino Médio Integrado (EMI) tem nesse cenário como o local adequado para a politecnia. $\mathrm{O}$ discurso oficial indica que dessa forma haveria a superação da oposição entre ensino propedêutico e ensino profissionalizante. Porém, apoiado em Kuenzer, o autor afirma que essa dicotomia é mais profunda e não se revolveria no plano da educação, pois está fundada na dicotomia entre capital e trabalho no contexto do novo regime de produção flexível. Ferretti afirma que na "perspectiva hoje concretizada, a educação profissional e tecnológica constitui-se no itinerário 
formativo verticalizado que tem seu horizonte ampliado para o pós-doutorado" (FERRETTI, 2011, p. 791) e esse itinerário pode ser percorrido em uma única instituição pública, o IF.

$\mathrm{O}$ autor destaca o papel dos professores no momento da transição entre o antigo e atual modelo de educação profissional trazido pelos IFs. O pesquisador coloca os docentes não como meros executores de política formulada por terceiros, mas se houver coletividade e apropriação da política pela escola e grupos de professores, seria possível realizar algumas escolhas, mesmo limitadas. O processo histórico do IFSP revela se tratar de uma instituição antiga, com tradição vinda do CEFET, que já realizava a verticalização do ensino e trabalhava em relação estreita com as demandas do mercado e pesquisa aplicada.

Sobre as condições de trabalho dos professores, estes já na época da transição entre os vários modelos de educação profissional que levaram a criação dos IFs manifestaram-se no sentido de busca por alternativas para a diminuição do número de aulas. O autor afirma que a maneira como estão organizados os IFs tende a isolar os professores do ensino técnico e os professores do ensino propedêutico, que acabam não realizando um trabalho conjunto, criando "feudos" e muitos outros conflitos dentro da instituição causados pelas constantes mudanças e imposições das legislações educacionais.

Além da perda de identidade trazida pelo modelo do IF ao transformar uma escola voltada primordialmente para o ensino técnico, há ainda outras críticas dos professores sobre a rápida multiplicação apressada dos campi pelo interior do Estado de São Paulo sem que estivessem, no entender de alguns entrevistados, criadas as estruturas e as condições de trabalho necessárias para a oferta de ensino de boa qualidade. Em suas entrevistas com os docentes há mais críticas aos efeitos negativos da verticalização para o ensino técnico, "que acabaria por perder espaço para os cursos de nível superior e, mais que isso, tenderia a ser desvalorizado, isto implicando a desvalorização profissional dos docentes vinculados ao primeiro" (Idem, p. 791).

O pesquisador afirma ainda que, no caso dos IFs, como há a exigência legal da instituição oferecer $50 \%$ das vagas para o ensino médio, haveria a possibilidade de todos os professores poderem atuar também no ensino superior, o que, obviamente, acarreta sobrecarga de trabalho, "implicando, como assevera Hypolito (2010, p. 1346), mais tarefas e responsabilidades extras, mais relatórios e registros escolares, maior intensificação do trabalho, menor tempo para preparação e estudo” (Idem, p. 800). 
Outro aspecto da verticalização que seria o plano de carreira dos docentes, que passa a valorizar mais a titulação do que a experiência no trabalho. Isso faz com que professores que realizam o mesmo trabalho recebam valores diferentes. Todas essas reformas vieram sem o devido debate e participação do corpo docente e técnico como forma de minimizar as possíveis resistências à materialização da agenda reformista.

$\mathrm{O}$ autor finaliza o texto enfatizando a necessidade dos professores conhecerem e estudarem o que vem a ser a formação politécnica e omnilateral, conforme proposta por Marx e Gramsci, especialmente se a educação politécnica for entendida na perspectiva marxiana, ou seja, como ação política e não apenas como estratégia pedagógica.

O artigo "A complexa construção de sentidos no cotidiano escolar: o caso da área de design do campus Pelotas do Instituto Federal Sul-rio-grandense" de Jair Jonko Araújo, publicado em 2014 discute como os professores da área de design do campus Pelotas do Instituto Federal Sul-rio-grandense (IFSul) estão produzindo sentidos em seus processos cotidianos de (re) construção da prática curricular, especificamente no ensino, na pesquisa e na extensão. Trata-se de uma pesquisa qualitativa, na qual os professores passaram por uma entrevista semiestruturada e a análise foi feita por meio da teoria do discurso.

$\mathrm{O}$ autor inicia o artigo tratando das características dos IFs, como instituições recentes, criadas a partir de outras escolas já existentes, como é o caso do Instituto Federal em questão. Nasce uma nova institucionalidade que requer uma nova identidade. O pesquisador buscou junto aos professores do IFRSG os sentidos, as "relações e os movimentos de resistência, enfim, discute, em uma instituição com privilegiado espaço de autonomia, possibilidades e limitações da autonomia docente para construção de práticas curriculares diferenciadas” (ARAÚJO, 2014, p. 210).

Tomando por base Ball, o autor discute os conceitos de política educacional, e afirma que ao mesmo tempo em que uma política está sendo construída está sendo contestada e alterada, dessa forma, o autor afirma que os professores investigados estão produzindo em seu cotidiano de trabalho, de forma complexa, sentidos para as políticas curriculares em construção no IFSul.

Nas falas dos professores que aparecem em destaque no texto, o autor primeiramente trata da transição da instituição para o modelo de IF e as novas demandas que isso traz, principalmente quanto à obrigação de que os professores realizem além do ensino, pesquisa e extensão. Os professores entrevistados demonstram certo desconforto 
ao dizer que nem todos sabem como lidar com essas demandas e acreditam ser importante regulamentar a carga horária docente.

No transcorrer da argumentação construída no artigo, Araújo destaca os conflitos internos existentes na instituição, principalmente aqueles causados a cada reforma educacional proposta pelo MEC. O autor ainda ressalta a fala de alguns docentes ao comparar os antigos e novos professores que vieram a partir da transformação do CEFET em IF no qual os novos professores, apesar de terem a titulação semelhante aos antigos, vinham com uma cultura universitária de foco na pesquisa, enquanto os antigos professores tinham o foco no ensino técnico.

$\mathrm{O}$ autor destaca as atividades de integração entre os alunos para que fossem realizadas atividades entre os estudantes do bacharelado e do técnico. Os professores afirmam que o fato de ter os alunos no curso superior oriundos do curso técnico traz mais qualidade e aprofunda o conhecimento. Ao mesmo tempo, nos discursos coletados, os professores indicam a falta de integração entre os professores dos componentes propedêuticos e os professores das áreas específicas.

O pesquisador finaliza o texto enfatizando a falta de cultura docente para a realização da pesquisa e da extensão e pergunta "Isto induz a questionar-se: o que é pesquisa e extensão para estes docentes ou de que pesquisa e extensão eles estão falando?” (Ibidem, p. 226). Ainda acrescenta que os professores assumem a pesquisa e a extensão como obrigação - é uma necessidade institucional, a instituição mudou e "tem o dever de", é uma necessidade em função do curso superior e que essas funções ainda estão "engatinhando" no campus e destaca a necessidade de regulamentação da carga horária docente. A verticalização é vista como um grande processo de reestruturação curricular. $\mathrm{O}$ autor destaca que os professores não se sentem intensificados, mesmo que possam se considerar cansados pelo grande número de demandas a serem atendidas e finaliza observando a necessidade de respeitar os espaços e tempos e de formação coletiva dos principais sujeitos do processo educacional: os professores e os estudantes.

O artigo de Deise Mancebo e João dos Reis Silva Júnior intitulado "Expansão da educação superior e a reforma da rede federal de educação profissional" publicado em 2015 discute a expansão da rede federal de educação profissional no Brasil, trata-se de uma pesquisa de caráter exploratório, baseada em pesquisa bibliográfica e análise documental.

Os autores indicam que a expansão da educação superior por meio dos Institutos Federais repete uma tendência mundial na educação superior, que é a 
diversificação de sistemas educacionais, comportando funcionalidades e arranjos diversos e destinado a segmentos populacionais também diferentes. Essa tendência “internacional é fortemente incentivada (praticamente induzida) por organismos internacionais, dentre os quais, o Banco Mundial que apresenta papel de destaque" (MANCEBO; SILVA JUNIOR, 2015, p. 74). Em documento de 1994 o Banco Mundial (BM) indica que o crescimento da educação superior deveria se dar pela via da expansão do ensino privado, busca de recursos alternativos ao ensino público (cobrança de mensalidade, por exemplo), busca de uma maior "eficiência" interna (otimização do uso do espaço físico, aumento do número de alunos por professor), ênfase na educação a distância, diversificação das instituições de ensino superior, entre outras. Destaca-se aqui a crítica do BM ao modelo da universidade de pesquisa, muito dispendiosa, por isso a defesa da criação de instituições de nível superior não universitárias.

Segundo os pesquisadores, quase vinte anos depois, o Brasil praticamente seguiu toda a cartilha do Banco Mundial, acompanhando uma tendência irreversível de diversificação da educação superior já presente na Lei de Diretrizes e Bases da Educação Nacional de 1996. O que o BM chama de "educação terciária" ressignifica a educação superior como ensino pós-secundário. Isto "parece afetar especialmente o trabalho do professor e a formação que, com muita facilidade, pode ser deslocada para mera capacitação ou até mesmo reciclagem" (Idem, p. 77) um ensino desvinculado da pesquisa e da produção crítica e criativa do conhecimento, mas organicamente vinculado ao mercado e suas demandas.

Os autores apresentam a concepção teórica da relação trabalho/educação que norteia a discussão, e como os processos educativos são chamados a cooperar com o modo capitalista de produção vigente, que dão sustentação às políticas neoliberais para a educação.

Os pesquisadores realizam ainda um breve histórico da educação profissional no Brasil, na qual fica clara desde o início a separação entre o ensino técnico e o ensino propedêutico no país, voltado para diferentes classes. O ano de 2004 foi marcante para os CEFETs, pois todos eles foram elevados à categoria de instituições de nível superior e, posteriormente, quase todos foram transformados em Institutos Federais, instituições de custos mais modestos que as universidades e que atendiam às demandas do Banco Mundial para diversificação do ensino superior.

A partir da criação dos IFs o ensino superior ganha novo lócus, que é chamado pelos autores de "hibridismo" devido a todas as novas demandas que os IFs teriam de 
dar conta. Os autores destacam ainda relatório do TCU que aponta a grave falta de docentes para atuar nos recém-criados Institutos, chegando a $20 \%$ no ano de 2013 . A falta de docentes faz com que os professores sejam sobrecarregados e tenham de atuar em todos os níveis, inclusive o superior, sem qualquer experiência ou formação, o que pode comprometer a qualidade do ensino, sem contar os atritos internos entre os docentes de maior titulação que não desejam lecionar em mais nenhum curso que não sejam os de ensino superior. Esses são os conflitos e tensões que marcam o campo pedagógico dentro de um IF. Os autores concluem afirmando que o

sistema federal de educação superior é composto de duas redes: a das universidades e a rede profissional. Os autores concluem que, a despeito do que é proclamado, têm objetivos, funções e controles distintos, além de se destinarem a públicos também diferentes (MANCEBO; SILVA JUNIOR, 2015, p. 89).

O trabalho de Arruda e Paula intitulado "Os Institutos Federais como instituição formadora de professores: expectativas e contradições" apresentado XVI Encontro Nacional de Didática e Práticas de Ensino (ENDIPE) em 2012 as autoras discorrem sobre as múltiplas funções atribuídas aos IFs, dentre elas, a oferta de licenciaturas para formar professores para atuar na educação básica como forma de suprir a carência desses no ensino médio, especialmente nas áreas de química, física, matemática e biologia. As autoras se propõem a "pensar o processo de deslocamento da formação docente para os IFs, instituições em que predomina a oferta de educação profissional e tecnológica" (ARRUDA; PAULA, 2012, p. 7).

No texto fica clara que a nova institucionalidade imposta às diversas escolas técnicas federais agrupadas para a criação dos Institutos Federais e que trouxe a possibilidade de levar ensino técnico e superior para regiões menos favorecidas do país, assim como resultou em desafios e metas calcadas em dados quantitativos. A previsão legal de ofertar educação básica profissional e nível superior leva as autoras a “questionar se paralelamente à verticalização das estruturas de poder, políticoadministrativas, não se instala também um movimento de flexibilização e polivalência da prática docente nestas instituições” (Idem, p. 9). As autoras afirmam que o perfil de professor que pode atender a tantas demandas concomitantemente se parece com o perfil do profissional exigido pelo capitalismo tardio, ou seja, um docente "flexível, 
polivalente e rápido na articulação de suas competências em prol dos objetivos da organização" (Ibidem, p. 10).

Diante desse cenário, surgem tensões entre os professores de maior ou menor titulação em lecionar em áreas de maior ou menor prestígio dentro da mesma instituição. As autoras indicam que o professor polivalente dos IFs também sofre intensificação do seu trabalho, impedindo-o de realizar a tríade ensino, pesquisa e extensão. As pesquisadoras ainda afirmam que essa polivalência do professor dos IFs requer que o trabalhador realize funções complexas e que requerem maior atuação cognitiva. As autoras finalizam o texto alertando para o risco dos IFs estarem criando um exército de reserva de licenciados que não necessariamente irá suprir as demandas por professores no ensino médio, isso porque a carreira docente continua não sendo interessante tanto pelos baixos salários quanto pelo desprestígio.

O trabalho "Adoecimento docente na Rede Federal de Educação Profissional, Científica e Tecnológica em Minas Gerais. Um fenômeno possível?" de autoria de Paulo Roberto Vieira Júnior, Maria Auxiliadora Monteiro Oliveira e Flávia Temponi Goes, apresentado no IV Seminário Nacional de Educação Profissional e Tecnológica (SENEPT) em 2014 aborda um tema comum na educação básica brasileira, que é a síndrome da desistência, também conhecia como síndrome de burnout. Os pesquisadores investigam até que ponto os professores da RFEPCT também estariam submetidos aos efeitos desse fenômeno que é relacionado "influenciado pelo cenário capitalista de produção que, em constante transformação, expõe o professor a extensa demanda de atividades e condições de trabalho inadequadas, as quais são geradoras de aumento de produtividade e consequente intensificação do trabalho (VIEIRA JÚNIOR; OLIVEIRA; GOES, 2014, p. 1).

Trata-se de uma pesquisa quantitativa de caráter exploratório e descritivo, o público foi composto de professores e professoras da Rede em Minas Gerais, foi utilizado um survey com 267 professores, dos quais 90 são do sexo feminino. Após a realização da pesquisa, foi constatado que os docentes pesquisados da RFEPCT de Minas Gerais tiveram menos afastamentos que os professores do mesmo estado, vinculados à rede de educação municipal e estadual. Os pesquisadores acreditam que as condições de trabalho na Rede Federal sejam mais favoráveis. A pesquisa aponta elementos iniciais sobre esse público, visto que há poucos estudos sobre o adoecimento dos professores que compõem a RFEPCT. Os autores concluem indicando a 
necessidade de prosseguir as pesquisas desse tipo, pois o trabalho docente está relacionado à melhoria nas condições de vida dos professores, no trabalho e fora dele.

$\mathrm{O}$ texto intitulado "O trabalho docente na educação profissional técnica" apresentado por Graziela Ninck Dias Menezes na 37ª Reunião Anual da Anped em 2015 trata da constituição da docência, e como os sentidos de trabalho e de técnica atravessam a profissão dos professores na EPT. A pesquisa foi desenvolvida no Instituto Federal da Bahia (IFBA), em um campus em processo de implantação. O estudo tem natureza qualitativa e se desenvolveu a partir da abordagem autobiográfica, utilizandose de entrevistas narrativas como dispositivo de pesquisa.

A autora faz um breve relato sobre as recentes mudanças acarretadas na educação profissional, em especial nos IFs e suas novas funções e fala das consequências para o trabalho dos professores: "Assim, surgem demandas para os docentes que implicam diretamente na organização didática do seu ensino, bem como nas práticas educativas que perpassam dimensões do trabalho docente intensificados no processo de implantação de novos campi [...]" (MENEZES, 2015, p.3).

A pesquisadora destaca ainda a dimensão objetiva das condições de trabalho docente e da organização do tempo como elementos para compreensão desse trabalho e para a constituição da identidade desse professor. Por meio de entrevistas narrativas a autora tece análise sobre "como o trabalho docente tem sido vivenciado no campus do IFBA em pleno processo de implantação e reestruturação dos cursos, trazendo demandas específicas para a produção da profissão docente neste contexto" (Ibid., 2015, p.4). Os professores entrevistados revelam a dificuldade em superar o dualismo entre o ensino técnico e o ensino propedêutico, especialmente no EMI, mostrando também como a produção do trabalho docente tem uma dinâmica que exige autonomia e um exercício vinculado às demandas da escola, dos programas ao mesmo tempo em que atua com as limitações do próprio processo de organização curricular que está em andamento.

A autora também fala das condições gerais do trabalho docente: "ficou evidente que diante da necessidade de atendimento das demandas administrativas, fruto da implantação de novos campi ou institutos, os professores vem passando por um processo de sobrecarga do trabalho" (Idem, p.7). Assim, o processo de produção de documentações e de organização da cotidianidade da escola, além do atendimento de alunos, implicam no trabalho docente que precisa ir se ajustando à medida que a própria organicidade da escola vai se construindo, exigindo um modo de atuar que perpassa pela 
gestão, pela elaboração de projetos, pelo desenvolvimento de atividades de ensino, pesquisa e extensão com demais profissionais da educação.

A autora conclui o trabalho afirmando que na

constituição dos Institutos Federais prevê-se a ampliação da produção de ciência e tecnologia ligada aos arranjos produtivos locais, ao desenvolvimento de competitividade do país, via atuação do trabalho de professores no campo do ensino, da pesquisa e da extensão." (MENEZES, 2015, p. 12).

E aponta para a cobrança sobre os resultados do trabalho docente. A autora finaliza destacando a importância de uma atitude reflexiva dos docentes sobre a finalidade da EPT para que possam assumir o controle da profissão e combater as circunstâncias que precarizam o trabalho docente bem como uma postura de investigação-ação sobre as situações-problema vivenciadas.

\subsection{Perspectivas de análise a partir do estado do conhecimento}

A busca por produções científicas e acadêmicas acerca do trabalho docente na verticalização dos Institutos Federais resultaram em poucos estudos sobre a verticalização em si. Foi possível constatar que normalmente o tema da verticalização aparece atrelado ao trabalho docente como tópico subjacente que leva o trabalho dos professores a uma condição inédita no cenário educacional brasileiro. A literatura não apontou, até o momento, que essa mesma condição de verticalização se repita em outros países. Assim, os docentes dos IFs têm de dar conta das múltiplas demandas trazidas por uma nova institucionalidade verticalizada, o que leva os professores a um trabalho flexível e polivalente, que tem de dar conta de todas as demandas da instituição, combinada com um trabalho docente fragmentado e intensificado, dificultando a realização da tríade ensino, pesquisa e extensão (ARRUDA; PAULA, 2012; FERNANDES, 2013).

A institucionalidade dos IFs foi um tema recorrente, pois agregou instituições antigas e criou outras totalmente recentes resultando em um hibridismo, tratando-se, portanto, de uma institucionalidade multifuncional, não havendo uma identidade própria para a unidade educacional (MANCEBO; SILVA JUNIOR, 2015; ARAÚJO, 2014; RUFINO NETO, 2012). Como os professores se comportam frente a essa nova 
instituição que não tem uma identidade própria? Os sentidos que cada professor atribui e como vai desenvolver sua prática pode se relacionar com sua formação e experiência profissional prévia. Depende de como se estrutura o IF ou campus em questão e suas condições materiais de trabalho. Uma nova institucionalidade que requer, portanto, uma nova identidade.

Ficou clara a contradição dessa institucionalidade, pois ao mesmo tempo em que os Institutos Federais representam a expansão e acesso à educação profissional em nível médio e o nível superior, especialmente nos locais mais distantes dos centros urbanos, também ficou evidente que a expansão se deu de maneira acelerada, e que nem todos os campi contam com os profissionais docentes e técnicos administrativos, bem como condições materiais de infraestrutura suficiente para execução da tarefa a que se propõem (GONÇALVES, 2014; ARRUDA; PAULA, Ibidem; FERRETTI, 2011).

Os atores que compõem a nova instituição não sabem com clareza o que é um Instituto Federal e qual o seu foco. Há uma demanda para que os IFs cumpram o papel das universidades e das escolas técnicas concomitantemente. Os professores recémconcursados têm o foco na pesquisa semelhante à universidade, ao mesmo tempo e no mesmo espaço físico, o que pode levar a falta de condições de trabalho, sobrecarga e excesso de demandas e intensificação do trabalho docente nos IFs. (GONÇALVES, 2014; ARAÚJO, Ibidem; MENEZES, 2015).

Já a verticalização foi tratada nos estudos numa conjuntura mais ampla da expansão do ensino técnico e superior aliada ao alcance de metas quantitativas determinadas por agentes externos a aos IFs, tais como órgãos de controle, a exemplo do TCU. O conceito de otimização já surge nesse contexto como diretriz do Banco Mundial para que as instituições de nível superior sejam diversificadas e que se tenha um sistema mais eficiente no qual os espaços físicos das instituições sejam totalmente aproveitados, bem como haja um aumento numérico na relação aluno/professor e, como resultado, tem promovido a diminuição da autonomia das instituições (MANCEBO; SILVA JUNIOR, Ibidem; RAMOS, 2011).

Nos estudos analisados, o papel dos CEFETs teve destaque nesse processo de transição, servindo como modelo de verticalização e integração para a criação dos Institutos Federais (FERNANDES, 2013). Esse processo de construção a partir da realidade dos CEFETs não significou apenas a justaposição de diferentes níveis e modalidades, uma vez que existia um histórico de desenvolvimento da educação profissional e, posteriormente, o mesmo quadro docente introduziu os cursos superiores 
nos mesmos eixos tecnológicos já existentes. Mas essa mesma transformação ocorrida nos CEFETs é possível ser replicada para os novos IFs e seus diversos campi?

Importante destacar que foi assinalada a ideia do Governo Federal em barrar a criação de novas universidades tecnológicas, pois se acredita que o modelo de universidade tende a se afastar da pesquisa aplicada e do ensino técnico (GONÇALVES, 2014). O modelo de CEFET, aquele que já realizava a verticalização, a pesquisa aplicada e tinha proximidade com o mercado seria o ideal a ser seguido para todo o Brasil, porém nos moldes de uma nova instituição denominada Instituto Federal (FERRETTI, 2011).

Contudo, a historicidade dos CEFETs foi negada a partir do momento em que se pretendeu repetir um modelo de escola que foi construído ao longo de quase um século. O modelo de educação que foi atingido pelos CEFETs não se deu espontaneamente. Surgiu por meio de circunstâncias políticas, econômicas e históricas determinadas. Tratou-se de um caminho percorrido de construção dessa realidade de escola pública federal de educação profissional e tecnológica com corpo docente qualificado e experiente. Grande parte dos novos IFs e seus diversos campi surgiram sem esse percurso histórico, ou a partir de uma escola agrotécnica, que não tem as características de verticalização e integração, corpo docente qualificado e infraestrutura consideradas ideais dos CEFETs, como é o caso do Instituto Federal de Brasília, objeto desta pesquisa.

Foram perceptíveis as tensões e os conflitos causados pela nova institucionalidade verticalizada no embate entre os antigos docentes das escolas técnicas federais e os novos docentes que acessaram os IFs após a sua criação por meio dos vários concursos públicos realizados. Nos estudos apresentados, há relatos de professores que esperam lecionar somente no ensino superior, pois não se sentem preparados para o ensino técnico nem do ponto de vista da sua formação inicial, nem da experiência profissional na área. Aqueles professores que atuam prioritariamente no ensino médio nos IFs poderiam se sentir desprestigiados ou relegados a um nível educacional considerado "menor" endossando a ideia de um corpo docente e uma carreira fragmentada internamente (FERRETTI, Idem).

Quanto à organização do trabalho pedagógico de maneira integrada e verticalizada, este envolve a necessidade do desenvolvimento de múltiplos currículos e a produção de sentidos dos docentes na reorganização da prática curricular. Foram destacadas as dificuldades dos professores em superar a dualidade entre o ensino técnico 
e o ensino propedêutico o que afeta a proposta de integração curricular. Mesmo entre os professores do ensino técnico e propedêutico há obstáculos para essa integração, além do excesso de carga horária, o que dificulta o planejamento coletivo, levando ao isolamento dos professores que realizam o trabalho de maneira fragmentada, privados do espaço coletivo. (MENEZES, Ibidem; VERDUM, 2015; ARAÚJO, 2014; FERNANDES, Ibidem).

As questões da falta de formação para que o docente possa atuar na verticalização e integração dos diversos níveis e modalidades, principalmente, mas não exclusivamente, os bacharéis docentes ${ }^{14}$ também apareceram como um fator importante na efetivação do trabalho docente nos IFs. A formação continuada dos professores ou o estabelecimento de indicadores de qualidade (FERNANDES, 2013) surgiu como solução para essa questão da atuação na verticalização, porém, a ênfase foi na formação ou nos parâmetros de qualidade como soluções para os problemas trazidos pela verticalização e não levaram em conta as condições objetivas de trabalho dos docentes.

A criação dos Institutos Federais se caracterizou predominantemente pelo fato de ser uma política de abordagem de cima para baixo ${ }^{15}$, ou seja, a percepção pelos professores de que as políticas públicas para a educação são imposições geram conflitos, contradições e embates dentro dos IFs, sem diálogo entre aqueles que pensam e aqueles que executam as políticas educacionais (ARAÚJO, 2014; RUFINO NETO, 2012; FERRETTI, 2011). O que transparece é a maneira como os decretos e leis são editados e, parece não haver participação dos principais interessados e envolvidos, os professores, que serão aqueles que levarão a cabo as políticas que se concretizam na instituição.

A partir da análise inicial do estado do conhecimento construído podemos perceber a emergência de algumas categorias de análise, tais como o ineditismo da proposta educacional dos IFs e suas consequências para o trabalho docente. A política de expansão da EPT e a forma como ela aconteceu de maneira acelerada e não necessariamente contando com as condições de trabalho para a realização da integração e verticalização. Ao falarmos em condições de trabalho para os professores dos IFs entendemos esse conceito como

\footnotetext{
${ }^{14}$ Bacharel docente é o professor que, embora esteja habilitado por concurso público como docente, tem a particularidade da formação em nível superior, mas não a formação em licenciatura ou complementação pedagógica para o exercício do magistério.

${ }^{15}$ Abordagem top-down perspectiva em que a decisão política é autoritária, em um nível central.
} 
O conjunto de recursos que possibilita uma melhor realização do trabalho educativo, e que envolve tanto a infraestrutura das escolas, os materiais didáticos disponíveis, quanto os serviços de apoio aos educadores e à escola. Tal equação se realiza, teoricamente, pela adequada relação fins e meios. Entretanto se as novas exigências educativas anunciadas pelas mudanças tecnológicas e societárias do atual momento histórico têm sido frequentemente assinaladas pelas políticas educacionais, o mesmo não tem ocorrido com as condições de exercício da prática educativa, que deve agregar novas funções sem o correspondente suporte prático. (CURADO-SILVA, 2008, p. 174).

No caso dos IFs, novas funções foram agregadas ao trabalho docente, como o fato de lidar com a verticalização, sem necessariamente o correspondente suporte prático que também envolve a infraestrutura e os serviços de apoio, principalmente de pessoal técnico. A percepção sobre a institucionalidade dos IFs pelos docentes foi uma categoria importante para compreensão de qual o foco dos Institutos Federais, a integração e verticalização da educação básica a superior no desenvolvimento de múltiplos currículos, bem como a integração do próprio corpo docente em torno de um novo projeto educativo.

Esta pesquisa avança nos demais estudos ao propor a discussão do trabalho docente na verticalização do Instituto Federal de Brasília, inserido em uma política de expansão educacional a partir de um referencial epistemológico crítico-dialético, buscando a análise dos estruturantes da verticalização no trabalho docente e na educação profissional, técnica e tecnológica. Para isso desenvolvemos uma investigação que tem o foco na educação profissional do DF e que envolveu professores de diversos campi que constituem o Instituto Federal de Brasília, buscando um olhar mais amplo e não restrito a apenas um campus. Esta abordagem procurou perceber a totalidade da política pública educacional e o movimento que ressoa na concretude materializada no trabalho docente. 


\section{PRINCÍPIO DA VERTICALIZAÇÃO NAS POLÍTICAS PÚBLICAS DE EDUCAÇÃO PROFISSIONAL E TECNOLÓGICA: ASPECTOS HISTÓRICOS E LEGAIS}

Historiar o contexto de evolução das forças produtivas, mesmo que de forma sintética, serve ao propósito de destacar o caráter classista da escola capitalista, que se volta, em todas as suas fases, para uma formação específica ao desempenho de um ofício funcionalista e imediatamente interessado à reprodução do capital, permitindo-lhe contribuir com a manutenção da lógica de acumulação do lucro. (SANTOS; JIMENEZ; SEGUNDO, 2013).

Este capítulo descreve os marcos históricos e as políticas públicas da educação profissional no Brasil que levaram à criação dos IFs e o princípio da verticalização. Discutir a respeito da historicidade da educação profissional no Brasil é tratar sobre uma modalidade de educação que historicamente é voltada à classe trabalhadora, bem como referir-se também à relação educação e trabalho. A educação profissional, enquanto fenômeno histórico-social é marcada pela dualidade e pelo assistencialismo (ANTONIAZZI, 2012; BRASIL, 2007; KUENZER, 2005). A dualidade entre ensino manual e o ensino intelectual é traço da educação básica no Brasil desde muito cedo, pois esta esteve assentada na separação entre trabalho manual e trabalho intelectual.

\subsection{Do escravismo à industrialização tardia}

O Brasil tem um contexto de relações de produção e trabalho escravo que assinala a composição da nossa sociedade. Tuppy (2007) afirma que "por essa história escravagista, o trabalho, principalmente o manual, consolidou-se como impróprio às camadas da população economicamente favorecidas." (p. 108). No então Brasil colônia, os demais trabalhadores livres não queriam estar associados aos mesmos tipos de trabalho realizados pelos escravos, como o artesanato e a manufatura.

Até o ano de 1909 não se pode falar formalmente em educação profissional no país, mas em práticas de se encaminhar os menores e os desvalidos para que aprendessem um ofício de maneira forçada para que posteriormente pudessem escolher livremente onde queriam trabalhar, o que criou um padrão que seria seguido anos mais tarde. 
Assim, em 1909 a educação profissional tem seu primeiro marco histórico no âmbito federal por meio do então presidente da República Nilo Peçanha, que com o Decreto no 7.566 de 1909 criou as dezenove Escolas de Aprendizes Artífices que, anos depois seriam transformadas em CEFETs e, posteriormente, nos atuais Institutos Federais.

As Escolas de Aprendizes Artífices formavam um sistema e foram instaladas principalmente nas capitais, demonstrando uma preocupação política, sob a ideologia do industrialismo e do assistencialismo.

Em 1909, o Brasil passava por um surto de industrialização, quando as greves de operários foram não só numerosas, como articuladas, umas categorias paralisando o trabalho em solidariedade a outras, lideradas pelas correntes anarco-sindicalistas. Neste contexto, o ensino profissional foi visto pelas classes dirigentes como um antídoto contra a "inoculação de ideias exóticas" no proletariado brasileiro pelos imigrantes estrangeiros, que constituíam boa parte do operariado. (CUNHA, 2000, p. 94 - grifo nosso).

Nesse cenário, as Escolas de Aprendizes Artífices tinham entre seus objetivos "habilitar os filhos dos desfavorecidos da fortuna com o indispensável preparo técnico e intelectual, como fazê-los adquirir hábitos de trabalho profícuo, que os afastará da ociosidade ignorante, escola do vício e do crime" (BRASIL, 1909). A dualidade permanece, porém, muda o enfoque do assistencialismo para a formação de mão de obra operária especializada para o exercício profissional (BRASIL, 2007).

Os ideais de industrialização do país estavam ligados a valores como o progresso e a emancipação econômica para que o Brasil se igualasse, ainda que de maneira tardia, ao desenvolvimento e a civilização que se encontrava na Europa e Estados Unidos. As escolas de Aprendizes Artífices funcionaram durante 33 anos, tiveram seu auge na década de 1920 e após entraram em decadência. A crise do capitalismo mundial de 1929 enfraqueceu o latifúndio cafeeiro e favoreceu o surgimento de uma burguesia industrial e comercial, que demandaria trabalhadores qualificados.

O ensino profissional é tratado pela primeira vez em uma Constituição no Brasil somente em 1937. O Artigo 129 deixa claro que o ensino pré-vocacional "destinado às classes menos favorecidas é em matéria de educação o primeiro dever de Estado" (BRASIL, 1937). No mesmo ano, as Escolas de Aprendizes Artífices se tornam Liceus Profissionais por meio da Lei $n^{\circ} 378$. A execução do ensino profissional estava aberta à 
iniciativa dos estados, dos municípios e dos indivíduos ou associações particulares e profissionais. Além disso, era dever das indústrias e sindicatos criar, na esfera da sua especialidade, escolas de aprendizes, destinadas aos filhos de seus operários ou de seus associados e assim, esses poderiam ser formados para um emprego e dar continuidade a sua condição de classe trabalhadora.

O percurso histórico da educação profissional federal passa em 1942 pela instituição do Sistema "S", que oferecia ensino técnico industrial voltado às camadas populares e de baixa renda como o objetivo de formar para um ofício, uma vez que o ensino industrial deveria atender "aos interesses das empresas" (BRASIL, 1942). Tratava-se da reforma educacional empreendida pelo então ministro da Educação Gustavo Capanema, que com o Decreto Lei 4.073, de 30 de janeiro de 1942, as Leis Orgânicas do Ensino, estruturou o ensino industrial, sendo as escolas industriais herdeiras das antigas Escolas de Aprendizes Artífices.

A última Reforma Capanema aconteceu em 1946, organizando as Escolas Agrícolas e Agrotécnicas que deveriam proporcionar formação aos trabalhadores agrícolas jovens e adultos. Aqueles que se formavam em cursos técnicos profissionalizantes somente poderiam acessar a universidade na sua área de formação profissional, diferente dos estudantes que cursavam o curso secundário propedêutico. Podemos perceber aí claramente uma política de separação entre o "ensino das elites que se destinariam ao trabalho intelectual e o ensino popular voltado para a preparação e o adestramento dos trabalhos manuais." (SAVIANI, 2005, p. 33).

Cabe ressaltar que todas as intensas transformações pelas quais o mundo do trabalho passou no Brasil nas décadas de 1930-40 os trabalhadores não se subjugaram por completo ou pacificamente. O crescimento da indústria concentrou nas grandes cidades o emprego e graves problemas sociais de moradia, saúde e educação. Os trabalhadores estavam sujeitos a péssimas condições de trabalho e a superexploração nas fábricas. Os movimentos grevistas e organizações do operariado se fortaleceram. Essas organizações foram fortemente combatidas pela burguesia industrial, não sem o apoio do Estado, especialmente na segunda Era Vargas (1951-1954), pronto a reprimir de maneira "enérgica" quaisquer ideias comunistas vindo do exterior, principalmente trazidas por trabalhadores estrangeiros. (BATISTA, 2015).

Em um mundo pós-guerra, dividido em dois grandes blocos político-militares entre os EUA e a URSS, o Brasil e a América Latina se viram sob a forte influência política e ideológica norte-americana. Havia um clima de prosperidade econômica 
incentivado pelo consumo. Em 1953 foi criado o Ministério da Educação e Cultura, que passou a responsabilizar-se pela educação. No ano de 1959, as "Escolas Industriais e Técnicas passaram à categoria de autarquias e foram denominadas Escolas Técnicas Federais" (OTRANTO, 2010, p. 90).

O Brasil passava por um momento econômico e político de transformações, aumenta o êxodo rural de uma população em busca de melhores condições de vida nos centros urbanos e tem início a instalação do parque industrial na região do $\mathrm{ABC}$ Paulista. Essa industrialização tardia se deu pela instalação de filiais de empresas multinacionais, que traziam a tecnologia já desenvolvida de fora do país, bem como enviava os lucros para suas matrizes. A formação da mão de obra especializada era uma necessidade para a produção em massa de bens de consumo na chamada sociedade urbano-industrial.

\subsection{Neoliberalismo e reformas educacionais}

A primeira Lei de Diretrizes e Bases da Educação (LDB) $\mathrm{n}^{\circ} 4.024 / 61$ foi sancionada em 1961. Nessa LDB “o ensino profissional foi equiparado ao ensino acadêmico e passou a ser considerado essencial para a expansão da economia baseandose nas escolas técnicas dos países industrializados" (FERNANDES, loc. cit., p. 15). Ainda assim, os alunos do ensino profissional enfrentaram o obstáculo de terem os currículos de seus cursos diferentes do que era cobrado nos vestibulares para acesso ao nível superior. Essa situação curricular foi parcialmente resolvida por algumas escolas e pela proliferação massiva de cursos pré-vestibulares.

Em plena ditadura civil-militar, na década de 1970, o país vivia o "milagre econômico" e o ensino profissional passa a ser obrigatório para todos que cursavam o ensino médio por meio da Lei 5.692/71. Essa forma de educação profissional foi julgada "um verdadeiro fiasco, considerando-se a falta de estrutura adequada para pô-la em prática" (TUPPY, loc. cit., p. 109) tanto nas escolas públicas quanto particulares espalhadas pelo país. Somente em 1982, por meio da Lei 7.044 as escolas de nível médio ficaram desobrigadas do ensino profissional compulsório estabelecido quase uma década antes.

A transição da década de setenta para a década de oitenta foi de criação dos Centros Federais de Educação Tecnológica (CEFETs) em diversos estados. Os CEFETs 
do Paraná, Minas Gerais e Rio de Janeiro, aproveitando a infraestrutura existente das antigas escolas técnicas federais (BRASIL, 2004) passaram a oferecer cursos em diversos níveis, como ensino médio técnico e superior, podendo ser considerado o precursor da integração e verticalização dos Institutos Federais.

A década seguinte foi para a educação profissional de muitas mudanças,

\begin{abstract}
A década de 1990 inaugura um novo momento na educação brasileira, comparável, em termos de mudanças, à década de 1960, em que se registrou a tessitura do que seria vivenciado nas duas décadas seguintes. Se nos anos de 1960 assiste-se, no Brasil, à tentativa de adequação da educação às exigências do padrão de acumulação fordista e às ambições do ideário nacional-desenvolvimentista, os anos 1990 demarcam uma nova realidade: o imperativo da globalização (OLIVEIRA, 2004, p. 1129).
\end{abstract}

O modelo taylorista-fordista de produção industrial e fabricação em larga escala possibilitou a prosperidade social e econômica e o desenvolvimento do Estado do BemEstar Social ${ }^{16}$ em países desenvolvidos da Europa (MELO, 2008). Esse modelo de racionalização da produção capitalista previa a especialização do trabalho e a linha de montagem, resultando na redução dos custos e, como consequência, produção em massa e consumo em massa.

No Brasil, a industrialização se deu de maneira tardia nos anos 1940 a 1970, de forma periférica e dependente de tecnologia estrangeira. Esse modelo entrou em crise com a reestruturação produtiva do modo de produção capitalista. A reestruturação capitalista foi um movimento global que teve início nos anos sessenta e prosseguiu nas décadas seguintes com consequências econômicas, políticas, sociais e culturais. Houve a redução do emprego, dos salários, aumento da pobreza e aprofundamento das desigualdades sociais.

O modelo de produção que se seguiu é conhecido como toyotismo, que surge a partir do desenvolvimento da microeletrônica e da automação, na qual o trabalho estritamente manual perde o predomínio. A produção toyotista "apresentava o trabalho intelectualizado como a nova e principal força produtiva das sociedades capitalistas contemporâneas" (AMORIM, 2014, p. 32). O novo modelo tem a característica da flexibilidade e multifuncionalidade. O trabalhador deveria ser polivalente e dar conta de

\footnotetext{
${ }^{16}$ Welfare State, Estado providência ou Estado Social posiciona o Estado como promotor e padrões de regulação social, garantindo serviços públicos de saúde, educação e proteção à população, considerandoos como direitos sociais.
} 
diversas atividades, requerendo uma educação mais especializada. A mesma tecnologia que aumentou a produção, também aumentou o desemprego, pois não seria mais necessária uma grande quantidade de trabalhadores para dar conta do processo produtivo realizado com a ajuda da tecnologia - o chamado desemprego estrutural -, substituindo o trabalhador especializado por um trabalhador polivalente.

No campo da educação, a reestruturação capitalista também trouxe mudanças, pois agora o trabalhador não deveria mais ser formado de maneira unilateral, característica da cultura fordista, mas deveria ser um "operário polivalente e multifuncional (...) requerido pela era toyotista" (ANTUNES, 1999, p. 112) e os sistemas educacionais acompanharam essa nova exigência. De acordo com Marx:

O que distingue as diferentes épocas econômicas não é o que se faz, mas como, com que meios de trabalho se faz. Os meios de trabalho servem para medir o desenvolvimento da força humana de trabalho e, além disso, indicam as condições sociais em que se realiza o trabalho (MARX, 1989, p. 204).

Para cada época um tipo de educação para dar conta dos respectivos meios de trabalho se faz necessária, implicando as mudanças nos sistemas educativos. $\mathrm{O}$ fim da década de setenta vê o surgimento do modo de produção capitalista em fase neoliberal, cuja ideologia propõe uma mudança no papel do Estado, com a mínima interferência na economia. No discurso neoliberal, a educação deixa de ser parte do campo social e político para ingressar no mercado e funcionar a sua semelhança (LOPES; CAPRIO, 2013).

No final da década de 1980, o modelo neoliberal avançava pelo mundo e chega fortemente no Brasil e na América Latina, por meio do que ficou conhecido como Consenso de Washington. Em 1989, uma reunião de representantes empresariais e economistas produziu um receituário neoliberal a ser seguido pelos países latino americanos, especialmente aqueles interessados em empréstimos e cooperação econômica com o Fundo Monetário Internacional (FMI), o Banco Mundial e o Banco Interamericano de Desenvolvimento (BIRD). Os países que realizam empréstimos ficam comprometidos com "condicionalidades ${ }^{17}$ que expressam a ingerência destes organismos nas políticas macroeconômicas e nas políticas setoriais dos países

\footnotetext{
${ }^{17}$ Por condicionalidades compreendemos o processo pelo qual os empréstimos financeiros concedidos pelos organismos internacionais estão condicionados à implementação de reformas na política macroeconômica e nas políticas setoriais à luz do projeto societário do capital. Cf. Leher, 1999.
} 
devedores" (LIMA, 2003, p.1). Há então, nos anos 1980, uma mudança de concepção no papel do Estado

era o de executor da política nacional de educação, e nos anos 90 passa a ser o coordenador desta política, cumprindo papéis supletivo e distributivo. Esses são alguns dos mecanismos introduzidos na legislação educacional estruturantes da ordem privada neoliberal, e uma das estratégias do Estado é a de organizar a educação, disponibilizando-a, em seguida, ao setor empresarial (SILVA, 2005, p.260).

De acordo com Fartes, juntamente ao novo padrão de regulação do Estado na reconfiguração dos setores produtivos nas décadas de 1980 e 1990 e, no caso do Brasil, desde o governo Collor, no início dos anos 90, "propagou-se a ideia da necessidade de recursos humanos mais qualificados, que dessem conta das novas demandas do setor produtivo" (2008, p. 658). A educação profissional vem se inserindo nesse contexto de reconfiguração também das suas políticas e legislação educacionais.

A partir da redemocratização do país, no final dos anos 1980 e na primeira metade dos anos 1990, quando, após a promulgação da Constituição Federal de 1988, entra em vigor uma nova LDB, a Lei $\mathrm{n}^{\circ}$ 9.394/1996, a partir da qual o ensino profissional no Brasil passa a ocorrer quase que exclusivamente nas Escolas Técnicas Federais, Escolas Agrotécnicas Federais e em poucos sistemas estaduais de ensino (BRASIL, 2007).

O então presidente Itamar Franco deu continuidade em 1994 à política de Collor com a Lei 8948/94, que transformou as Escolas Técnicas Federais em Centros Federais de Educação Tecnológica, nos mesmos moldes dos CEFETs MG, RJ e PR, que já existiam desde 1978. Essa lei restringiu na prática a expansão das escolas federais, pois no Artigo $3^{\circ}$ assinalava que a expansão "somente" poderia ocorrer em parceria com estados, municípios, Distrito Federal, setor produtivo ou organizações não governamentais responsáveis pela manutenção e gestão das novas unidades, resultando em um período de estagnação da educação profissional federal. Somente em 2005 essa situação seria revertida no governo Lula com a Lei $\mathrm{n}^{\circ} 11.195$ que substituiu o termo "somente" por "preferencialmente".

Ainda em 1994 houve a proposta de criação do Sistema Nacional de Educação Tecnológica cuja espinha dorsal eram os CEFETs. Esse sistema, conforme Kuenzer (1994) separa a educação básica da formação profissional "voltando a propor uma escola para intelectuais (dirigentes) e outra para os trabalhadores (técnicos).” (p. 123). 
Nessa época já estava prevista a oferta de cursos para formação de tecnólogos com “forte componente 'prático' em detrimento do 'científico', como se fosse possível técnica sem ciência" (Ibidem, p. 124). Além disso, a autora trata também da verticalização do ensino.

\begin{abstract}
A proposta do Sistema de Educação Tecnológica apresenta como um dos princípios norteadores, a verticalização do ensino, de modo a assegurar a continuidade dos estudos dentro do sistema, do primeiro grau à pós-graduação, estabelecendo 'um continum de oferta de ensino com rígida seletividade, na formação de recursos humanos na área tecnológica'. (Idem, Ibidem, p. 126 - grifo original).
\end{abstract}

A autora teceu críticas a essa proposta com o argumento de que o seu objetivo era perpetuar as diferenças sociais por meio da expansão de escolas técnicas voltadas para a satisfação de interesses práticos e imediatos, oferecendo um tipo de escola própria para determinado grupo social.

A atual LDB, Lei no 9394/96, considerada a segunda Lei de Diretrizes e Bases que dispõe sobre a educação profissional em um capítulo separado da educação básica, afastando no texto os enfoques de assistencialismo e de preconceito social contido nas primeiras legislações de educação profissional do país. Além disso, foi definido o sistema de certificação profissional que permitiu o reconhecimento das competências adquiridas fora do sistema escolar. Apesar disso, a LDB se mostrou desde a sua criação um documento legal que tinha como objetivo "se adaptar às diretrizes neoliberais internacionais para a educação (LEHER, 1997; MELO, 1998 apud NEVES, 2000, p. 153). Dentre essas diretrizes podemos citar no âmbito da educação superior

a) a expansão de instituições privadas através da liberalização dos serviços educacionais; b) o direcionamento das instituições públicas para a esfera privada através das fundações de direito privado, das cobranças de taxas e mensalidades, do corte de vagas para contratação dos trabalhadores em educação e, entre outros, do corte de verbas para a infraestrutura das instituições (SILVA, 2003, p. 2).

Essas orientações são provenientes de documento ${ }^{18}$ editado pelo Banco Mundial datadas em 1994 que, entre outros, indica ainda a necessidade de diversificar as instituições de ensino superior com a criação de instituições não universitárias, tal qual

\footnotetext{
${ }^{18}$ La enseñanza superior. Las lecciones derivadas de la experiência, Banco Mundial, 1994.
} 
são hoje os Institutos Federais, que não se tratam de universidades tradicionais, mas um híbrido de educação básica e educação superior, que ainda oferece cursos de curta duração e educação a distância.

A LDB, ao se referir sobre a EPT de Nível Médio, trata da formação de um profissional adaptável, flexível, capaz de continuar aprendendo. É uma legislação que se apropria de uma linguagem que produz um léxico educacional econômico e gerencial (SHIROMA; CAMPOS; GARCIA, 2005). Aparentemente,

quanto mais se consolida uma sociedade global baseada na produção de bens de consumo, mais se tende a incorporar como objetivo da educação, transformado em lei, a preparação ou a qualificação para o trabalho econômico (TUPPY, op. cit., p. 108).

A Lei de Diretrizes e Bases que se encontra hoje vigente foi aprovada na mesma época em que se discutiam o Plano Nacional de Educação (PNE) e o Plano Decenal de Educação para Todos. Esse Plano Decenal "é resultado dos compromissos internacionais assumidos pelo Brasil, na Conferência de Educação para Todos, ocorrida em março de 1990, em Jomtien, Tailândia" (LIMA, 2008). A educação, de maneira geral, observou um movimento de retração do Estado, redução de custos e privatização. Como resultado dessas políticas educacionais, o foco da educação manteve-se por anos no Ensino Fundamental, ficando em segundo plano a educação infantil, o ensino médio, a educação de jovens e adultos, o ensino superior e a educação profissional.

Em 1997, durante o governo do presidente Fernando Henrique Cardoso, o ministro Paulo Renato, então titular do MEC, assinou o Decreto no 2.208 de 1997, que separou o ensino médio da educação técnica e, segundo profissionais da educação, empobreceu os currículos na educação profissional. $\mathrm{O}$ argumento para a separação era de que a educação profissional brasileira, o antigo segundo grau, atendia a interesses elitistas. Ao invés de expandir e promover a democratização do acesso ao ensino técnico de qualidade, o então governo preferiu enfraquecê-lo. Esse decreto completou

o desmonte da estrutura educacional desenvolvimentista pré-existente, dando à educação de jovens e adultos, ao ensino médio, à educação tecnológica, à formação profissional e à educação superior uma cara própria, de feições neoliberais, facilmente comprovadas, tanto pela análise das propostas dos organismos internacionais para a educação escolar na América Latina, como pela análise das propostas de política educacional governamental (NEVES, 2000, p. 165). 
Nos anos 2000 chegou-se a acreditar na privatização das escolas técnicas, pois estas se pautavam por demandas imediatas das empresas "e pela busca de recursos financeiros no mercado, seja pela venda de cursos a quem esteja disposto a pagar por eles" (CUNHA, 2000, p. 106).

Essa situação se alterou a partir da mudança de governo, o presidente Lula, por meio da SETEC do MEC iniciou em 2003 a expansão da Rede Federal dividida em três fases: a fase I, de 2003 a 2006, e a fase II, de 2006 a 2010 e $3^{\text {a }}$ fase, que se estenderá até 2020. O lema da primeira fase foi "uma escola técnica em cada cidade polo do país", no qual os estados onde não havia escolas federais foram contemplados. Essa expansão também envolveu o Programa Nacional de Acesso ao Ensino Técnico e Emprego (Pronatec) criado por meio da Lei 11.513/2011 para a oferta de cursos de formação profissional, não só pelas instituições públicas, mas a partir de 2013 também pela iniciativa privada, repassando importantes recursos públicos para o ensino particular.

Conforme Bresser-Pereira (2013) "Há duas formas de organização econômica e política do capitalismo, o liberalismo econômico e o desenvolvimentismo." (p. 21) e essa última parece ter sido a escolha dos governos Lula e Dilma para o país numa "tentativa de se estruturar o capitalismo brasileiro também como um novo desenvolvimentismo socialdemocrático e, agora, também ambiental.” (Idem). A relação trabalho-capital-Estado derivou em ações concretas no estabelecimento de políticas públicas para a educação profissional. A tentativa de realizar a coalizão de classes antagônicas - trabalhadores e empresários - expressou-se objetivamente no processo de criação das políticas educativas para a classe trabalhadora, conforme veremos a seguir com a criação dos IFs.

\subsection{Criação dos Institutos Federais}

Buscando atender às pressões e cumprir compromissos feitos em campanha, no ano de 2004 o então presidente Luís Inácio Lula da Silva revogou o Decreto 2.208/97, o que propiciou novamente a articulação entre o ensino médio e o ensino técnico. Ainda assim, não se podia considerar que havia uma política estruturada, que pudesse integrar programas isolados e contingentes para a formação profissional. (TUPPY, op. cit.). No mesmo ano de 2004, por meio do decreto o Decreto $n^{\circ} 5.225$, os CEFETs foram transformados em Instituições de Nível Superior (IES) e já eram então considerados 
instituições pluricurriculares, ofertando educação nos diferentes níveis e modalidades de ensino, com prioridade para atuação na área tecnológica, assim como são atualmente os Institutos Federais.

Ainda em 2004 o MEC apresentou documento com propostas e discussões sobre as políticas públicas para a EPT que orientou a SETEC e coordenou ações de governo, nesse sentido a reorganização da rede de educação profissional e tecnológica se propôs a manter firmemente alguns princípios básicos, entre eles "Articulação verticalizada entre os vários níveis de ensino em áreas tecnológicas, promovendo oportunidades para uma educação continuada e otimizando o uso comum da infraestrutura existente." (2004, p. 45). Estavam lançados os preceitos da verticalização e otimização dos IFs.

As diretrizes que integrariam as instituições federais de educação tecnológica foram estabelecidas em 2007, com o objetivo de criação dos Institutos Federais. O Decreto n 6.095 falava em "agregação voluntária" das escolas federais localizadas em um mesmo estado para a criação dos futuros IFs, tendo os CEFETs como futuras reitorias das novas instituições. De acordo com estudo ${ }^{19}$ realizado por Otranto (2010) cada instituição respondeu de forma diferente a esse decreto.

O objetivo das Escolas Agrotécnicas era de se tornarem instituições de nível superior, mas na forma de CEFET, além disso, havia a preocupação com a perda de identidade e de autonomia, visto que as EAFs seriam um campus subordinado a uma reitoria, muito provavelmente encabeçada por um CEFET. O Conselho das Escolas Agrotécnicas Federais (CONEAF) chegou a elaborar um documento rechaçando a proposta governamental, porém, segundo relatos de representantes das EAFs, a não adesão ao modelo de IF poderia trazer "consequências indesejáveis" para as escolas tais como a falta de recursos e ampliação do quadro docente e o MEC havia deixado claro a total impossibilidade de transformação das EAFs em CEFETs. Todas as EAFs aderiram ao novo modelo ou "correriam o risco de morrer a míngua" (Idem, p.7).

Nem todos os CEFETs aderiram ao projeto de ifetização, ficando de fora Centros Federais de Educação Tecnológica Celso Suckow da Fonseca, no Rio de Janeiro e o de Minas Gerais que desejam transformarem-se em Universidade Tecnológica, assim como aconteceu com o CEFET-PR que atualmente é Universidade Tecnológica Federal do Paraná (UTFPR), mas até hoje sem sucesso. Em 2011 foi

\footnotetext{
${ }^{19}$ Estudo realizado com 35 instituições de educação profissional que avaliaram a opção da transformação em IF.
} 
noticiado ${ }^{20}$ pelo Jornal Estado de Minas crise no CEFET-MG em virtude da dificuldade em conseguir contratar professores por meio de concurso público, mencionando inclusive uma possível "retaliação" à instituição pela não adesão ao modelo de IF. Os demais CEFETs aderiram à proposta e o Conselho de Dirigentes dos Centros Federais de Educação Tecnológica (CONCEFET) se manifestou positivamente, inclusive diversas de suas sugestões foram incorporadas a lei de criação dos IFs.

Já as Escolas Vinculadas às Universidades Federais viram a possibilidade de expandir sua área de atuação, mas também as preocupava o fato de se tornarem campi subordinados a um CEFET. O Conselho Nacional de Dirigentes das Escolas Técnicas vinculadas às Universidades Federais (CONDETUF) se manifestou, pois gostaria de ter participado das discussões Decreto $\mathrm{n}^{\circ}$ 6.095/07, destacando ainda que a ifetização era uma proposta complexa e que faltou uma discussão técnica e política com as Escolas Vinculadas às Universidades Federais. Como resultado, 24 das 32 Escolas não aderiram à proposta. Havia ainda o temor de que os cursos a serem oferecidos pelos futuros campi "atendessem aos interesses privados locais mais imediatos" (Ibid., p.13).

Completando a transição, em 2008, o presidente Lula sancionou a Lei $\mathrm{n}^{\circ} 11.892$ que instituiu a Rede Federal de Educação Profissional, Científica e Tecnológica no âmbito do sistema federal de ensino e criou os Institutos Federais de Educação, Ciência e Tecnologia. A Rede Federal é vinculada ao MEC e constituída pelas seguintes instituições: Institutos Federais de Educação, Ciência e Tecnologia; Centros Federais de Educação Tecnológica; Escolas Técnicas Vinculadas às Universidades Federais; Universidade Tecnológica Federal do Paraná e Colégio Pedro II.

Os Institutos Federais, surgidos em consequência da reconfiguração das escolas federais já existentes, escolas essas com organização administrativa e pedagógica, corpo docente e técnico estruturados para certo tipo de ensino - fosse ele agrícola, industrial ou tecnológico - tiveram de percorrer um trajeto de mudanças na sua organização administrativa e pedagógica para que chegassem ao modelo verticalizado de IF.

\footnotetext{
${ }^{20} \mathrm{http}$ ///jornalggn.com.br/blog/luisnassif/a-crise-do-cefet-mg?page=1acessado em 16/02/2016 http://wwo.uai.com.br/EM/html/sessao_18/2011/04/19/interna_noticia,id_sessao=18\&id_noticia=177266/ interna_noticia.shtml
} 
A partir das reformas da educação profissional impulsionadas pelo Decreto $\mathrm{n}^{\circ}$ 5.154 de 2004, que regulamentou a educação profissional e preparou o terreno nos CEFETs para a criação dos Institutos Federais e veio segundo os professores ${ }^{21}$

'recolocar as coisas mais ou menos no lugar' sem, no entanto, apagar o sentimento de insegurança decorrente das modificações pelas quais a escola continuaria a passar, com atribuições de novas responsabilidades, como a de incluir entre seus cursos o Programa Nacional de Integração da Educação Profissional com a Educação Básica na Modalidade de Educação de Jovens e Adultos - Proeja -, instituído pelo Decreto n. 5.840/06 e, concomitantemente a este, os cursos de formação de docentes para atuarem naquela modalidade de ensino (FARTES, 2008, p. 664).

Essa fala reflete a realidade de professores que atuavam em CEFETs perante as alterações na configuração da educação técnica federal, e um prenúncio de novas mudanças ainda por vir, por exemplo, as novas responsabilidades que seriam atribuídas às escolas técnicas e aos seus docentes.

No mais recente Plano Nacional de Educação, com vigência para o período de 2014 a 2023 e que foi aprovado após três anos de discussões, constam duas metas para a educação profissional. A meta 11 do PNE tem o objetivo de triplicar as matrículas da Educação Profissional Técnica de nível médio, assegurando a qualidade da oferta e pelo menos 50\% da expansão no segmento público (BRASIL, 2014). Atualmente existem 644 unidades dos IFs cobrindo todo o país na proporção média de uma unidade para cada dez municípios, com diversos campi ainda em construção, funcionando em instalações provisórias e outros aguardando a instalação total de seus laboratórios, e os espaços culturais, de vivência, de esporte e cultura.

Diante desse cenário histórico podemos afirmar que

(...) no breve Século XX (HOBSBAWM, 1994), o Brasil passou de um regime de trabalho assentado na condenação de um povo - o trabalho escravo - para um modelo que vincula, perversamente, a falta de emprego ou de ocupação com incompetência e baixa qualificação individual, num cenário em que a maioria da classe trabalhadora é instada a construir, de modo supostamente livre, sua empregabilidade. Não podemos, ainda, ignorar na análise, a complexificação de nosso padrão de sociabilidade, tendo em conta tanto as transformações ocorridas nas formas de lutas populares quanto nos padrões de atuação

\footnotetext{
${ }^{21}$ Pesquisa realizada por Vera Lúcia Bueno Fartes em CEFETs da Região Nordeste, a partir de entrevistas individuais e grupos focais para conhecer as percepções sobre a reforma da educação profissional iniciada em 2004.
} 
burguesa, bem como as contradições de longa duração que remontam aos traços de nossa colonização. (RUMMERT, 2013, p. 406).

É nessa conjuntura de transformações históricas, econômicas e políticas da educação profissional no Brasil, entre lutas, avanços e retrocessos, que resultam os Institutos Federais de Educação. Todo o percurso histórico, que separa a origem das primeiras escolas técnicas federais, ainda nos primeiros anos do século XX e a criação dos Institutos Federais, no início do século XXI não foi homogêneo no que se refere à educação profissional como política de estado ou de governo ${ }^{22}$.

De política assistencialista aos desvalidos da sorte à estreita relação do Estado como garantidor da formação da classe trabalhadora em iniciativas públicas e privadas voltadas para as necessidades do mercado, a educação profissional passou por períodos de valorização, protagonismo e estagnação. A volta do protagonismo dessa modalidade de ensino no momento atual se dá a partir da reestruturação da educação profissional “[...] inserida no conjunto de medidas de enxugamento dos gastos públicos e de otimização dos investimentos do Estado [...]” (VARGAS, 2013) com a instituição de uma Rede Federal com escolas dedicadas ao ensino profissional, técnico e tecnológico e por meio de programas e políticas públicas de governo para a educação da classe trabalhadora.

Atualmente $^{23}$, a educação profissional e tecnológica no país é composta principalmente pelo Sistema S, Universidades públicas e privadas, escolas e centros mantidos por sindicados de trabalhadores, escolas e fundações mantidas por fundos empresariais, escolas técnicas privadas, estaduais, municipais e a Rede Federal de Educação Profissional, Científica e Tecnológica, presente em todo território nacional. Na Rede Feral encontram-se os Institutos Federais, instituições que abrigam ao mesmo

\footnotetext{
${ }^{22}$ Políticas de Estado estão associadas às competências institucionais, legais e permanentes dos entes estatais, normalmente envolvendo poderes, órgãos e esferas diversas. Políticas de Governo são as políticas que prevalecem do processo eleitoral e podem ter caráter passageiro ou circunstancial.

${ }^{23}$ No dia 31/08/2016 o plenário do Senado aprovou o impeachment da presidenta Dilma Rousseff. Em seu lugar assumiu o vice-presidente Michel Temer com uma agenda de reforma da educação profissional de nível médio por meio de Medida Provisória (MP). A reforma prevê uma flexibilização do EM - as disciplinas seriam organizadas por áreas de conhecimento, com todos os alunos frequentando um ano e meio de aulas comuns e, após esse período, podendo optar por áreas específicas de estudo ou iniciar um percurso de ensino técnico profissionalizante. A MP ressalta o caráter autoritário do atual governo cuja proposta de reformulação contempla um modelo de política pública não participativa, exemplificando a ausência de legitimidade política de um governo que chega ao poder sem o voto popular. http://www.anped.org.br/news/com-iminencia-de-implementacao-de-reforma-curricular-no-ensinomedio-pesquisadores-apontam
} 
tempo o ensino médio, o ensino superior e uma variedade de cursos e programas de qualificação, constituindo assim a verticalização como uma de suas características.

O ensino profissional muitas vezes é visto como "uma espécie de panaceia para os mais diversos problemas sociais, econômicos e culturais do país" (CUNHA, 2000, p. 99) por isso, a importância de se pensar como as políticas de expansão da EPT também estão influenciando o trabalho docente, aquele que materializa a política nas instituições, nas salas de aula, nos laboratórios, no ensino, na pesquisa e extensão. 


\section{INSTITUTOS FEDERAIS: TRABALHO DOCENTE NA VERTICALIZAÇÃO}

O ideário da reforma educacional atribui ao professor um protagonismo fundamental. Paradoxalmente, nele identifica a responsabilidade pelas mazelas do sistema público de ensino e o mágico poder de extirpá-las. (SHIROMA; MORAES; EVANGELISTA, 2007).

Neste capítulo analisamos a relação entre os estruturantes do trabalho docente e as características da verticalização na educação profissional, técnica e tecnológica do IFB. Iniciamos a partir do discurso oficial de sustentação da política ao ideal da verticalização e integração educacional e suas implicações para o trabalho docente. As principais abordagens teóricas do trabalho docente são destacadas para que possamos compreender suas especificidades e o seu desenvolvimento no Instituto Federal de Brasília.

\subsection{O trabalho docente na verticalização e integração educacional}

A política educacional que possibilitou a criação dos IFs como unidades educacionais verticalizadas foi implementada em partes. Primeiro com a transformação dos CEFETs e demais escolas federais e, posteriormente, com a criação dos Institutos Federais. A questão da verticalização somente ficou clara a partir de 2008 com a instituição da Rede Federal e a consequente criação dos Institutos Federais.

A verticalização implica na oferta concomitante de cursos em níveis e modalidades diferentes, perpassando a educação profissional, técnica e tecnológica. A diversidade de ofertas faz parte do currículo dos Institutos Federais, pois contempla como princípio em sua proposta político pedagógica

(...) ofertar educação básica, principalmente em cursos de ensino médio integrado à educação profissional técnica de nível médio; ensino técnico em geral; cursos superiores de tecnologia, licenciatura e bacharelado em áreas em que a ciência e a tecnologia são componentes determinantes, em particular as engenharias, bem como programas de pós-graduação lato e stricto sensu, sem deixar de assegurar a formação inicial e continuada do trabalhador e dos futuros trabalhadores (BRASIL, 2008, p. 27).

Por essa característica, os professores dos Institutos Federais estão sujeitos em seu trabalho às especificidades da educação básica, superior e profissional, além do 
desenvolvimento de atividades de pesquisa e extensão em uma institucionalidade totalmente nova no âmbito educacional.

Eliezer Pacheco, então titular da Secretaria de Educação Profissional e Tecnológica do Ministério da Educação à época da instituição da RFEPCT descreve a verticalização como uma proposta pedagógica que oferta educação básica, ensino técnico e graduações. Dessa forma, o desenho curricular da oferta educativa de um Instituto Federal é um aspecto constituinte da verticalização. Pacheco (2011) afirma ainda que o diálogo que se pretende estabelecer entre educação e tecnologia é o que se chama de transversalidade, uma vez que essa tecnologia está presente na tríade ensinopesquisa-extensão. Dessa forma, a arquitetura curricular organiza a EPT em eixos tecnológicos.

Ainda na concepção criadora dos IFs, o eixo tecnológico é o que sustenta e organiza o currículo e a identidade dos cursos e dá o direcionamento do projeto pedagógico de cada campus. Os currículos, centrados nas dimensões tecnológicas envolvem a formação profissional que se pretende dar ao aluno, a prática do como fazer e as relações sociais implícitas nas tecnologias. A verticalização, então, organiza os conteúdos curriculares de forma que estes dialoguem entre as várias formações ofertadas. Dessa maneira, a verticalização permite ao aluno traçar um itinerário formativo do ensino básico ao nível superior (PACHECO, Ibidem).

Por terem um currículo tão abrangente, os Institutos Federais podem estabelecer uma arquitetura curricular com característica única: a flexibilidade na construção de itinerários formativos, integrando educação básica e ensino superior, educação profissional e tecnológica e a possibilidade de ofertar educação continuada em consonância com a realidade produtiva (BRASIL, 2008b).

Temos, assim, a verticalização como a estrutura organizacional da nova institucionalidade dos Institutos Federais, de maneira que os múltiplos currículos transitam de forma a traçar um itinerário formativo para o corpo discente, que prossegue e verticaliza seus estudos nos diversos níveis e modalidades oferecidos por cada campus. Essa flexibilidade curricular da verticalização na formação do estudante oportuniza aos professores [...] entre outras coisas, associar teoria e prática em qualquer dos níveis de ensino, permitindo-lhes uma visão mais ampla da educação e de suas relações com o mundo do trabalho e com a sociedade em geral. (CONCEFET, 2007, p. 9). 
Os professores que atuam nos IFs não necessariamente irão lecionar no mesmo eixo tecnológico, podendo percorrer diferentes eixos, níveis e modalidades em um mesmo dia de trabalho, possibilitando a realização de uma tarefa bastante incomum em uma instituição pluricurricular. Devemos considerar que o currículo evidencia os conflitos de interesses e as forças que se equilibram em um dado momento histórico e por meio dele se realizam os objetivos educacionais propostos. O currículo descreve "a concretização das funções da própria escola e a forma particular de enfocá-las num momento histórico e social determinado, para um nível ou modalidade de educação, numa trama institucional.” (SACRISTÁN, 2000, p. 15).

A verticalização enquanto termo para designar o desenvolvimento curricular educacional só encontra respaldo na política de criação dos Institutos Federais. O termo verticalização tem muitas acepções e isso ficou evidente durante o levantamento bibliográfico para a realização do estado do conhecimento, no qual foram encontrados diversos trabalhos científicos, das áreas mais distintas, todos tratando sobre verticalização dentro de seus respectivos contextos. Ao comparar o currículo verticalizado dos IFs com uma "arquitetura curricular" (PACHECO et. al. 2010, p. 81), somos remetidos à área de conhecimento da Arquitetura, na qual a verticalização é tratada como um fenômeno que

(...) pode ocasionar mudanças no meio físico, acarretando impactos ambientais no clima urbano, na drenagem, na cobertura vegetal, no conforto térmico, no sossego público, na mobilidade e na qualidade do ar. (...) a verticalização aumenta a superfície impermeabilizada, o tráfego de veículos e, consequentemente, a poluição; surge o sombreamento que causa contrastes térmicos entre a parte sombreada e a ensolarada. A verticalização também pode promover a sensação de "estreiteza" das ruas e o estrangulamento dos pátios e pode ocasionar a falta de privacidade pela proximidade das edificações (LEE, 2011). (SILVEIRA; SILVEIRA, 2014, p. 291).

Essa circunstância nos revela a materialidade das condições de trabalho ao tratar da arquitetura dos Institutos Federais que, em tese, deveria estar apta a receber todos os níveis e modalidades a que se propõe um currículo verticalizado e integrado. $\mathrm{O}$ CONCEFET (2007), órgão que referendou a política dos Institutos Federais ressalta que esse projeto de IF se daria com base em garantia de iguais condições de recursos humanos e materiais aos atuais CEFETs da época. Sendo assim, a verticalização nos IFs, além de estrutura curricular também pressupõe infraestrutura escolar para a realização do trabalho, uma vez que 
Qualquer que seja a proposta dentro dessa perspectiva, ela vem facilitada pela infraestrutura existente na rede federal. Os espaços constituídos, no tocante às instalações físicas dos ambientes de aprendizagem, como salas de aulas convencionais, laboratórios, biblioteca, salas especializadas com equipamentos tecnológicos adequados, as tecnologias da informação e da comunicação e outros recursos tecnológicos são fatores facilitadores para um trabalho educativo de qualidade, que deve estar acessível a todos. (PACHECO, Ibidem, p. 25).

A infraestrutura, porém, nem sempre está presente e muitas vezes é insuficiente nos campi que compõem a rede de Institutos Federais (FERRETTI, 2011; GONÇALVES, 2014).

A verticalização tanto na arquitetura quanto na educação parece ter consequências no acúmulo de funções, uma vez que, na proposta dos IFs o mesmo espaço físico de cada um de seus campi abriga diferentes níveis e modalidades de ensino, com as mesmas salas de aula, laboratórios, biblioteca, enfim, a infraestrutura de uma escola de educação básica e de uma universidade estarão sobrepostas. Somem-se a isso os mesmos professores serão responsáveis por dar conta dessa arquitetura curricular. Ainda nos estudos do campo da arquitetura e urbanismo, "a dinâmica de verticalização (...) obedece a uma lógica própria. A superposição de lajes é o princípio de expansão e ampliação do imóvel" (IVO, 2012, p. 142).

O conceito de superposição, em paralelo com os Institutos Federais, os níveis e modalidades tais como o ensino profissional, a educação básica e a educação superior passam a estar superpostos em suas unidades educacionais. A verticalização no conceito da arquitetura provoca um adensamento populacional agravando as condições de moradia e precarizando o ambiente construído (IVO, Idem).

Assim, a institucionalidade dos IFs passa pela característica da verticalização, em uma instituição educacional pluricurricular que, ao mesmo tempo, possibilita o compartilhamento de um espaço único, no qual os alunos do ensino médio podem conviver com os alunos dos cursos superiores, dividindo o ambiente de ensino e pesquisa, podendo haver o traçado de um itinerário formativo, ou seja, o diálogo entre os cursos da educação básica ao nível superior (SILVA, 2009), assim como também pode indicar a inadequação e precarização de um mesmo espaço para tantas funções.

É interessante ressaltar que no contexto desta pesquisa falar sobre a arquitetura de um Instituto Federal é dizer sobre condições de trabalho, ou seja, uma mesma 
estrutura física de um IF tem de atender a demandas tão diferenciadas quanto o ensino médio técnico, Proeja, cursos tecnológicos de nível superior, bacharelados, licenciaturas e pós-graduação. É relevante discutir a existência de espaços adequados para o desenvolvimento do trabalho dos professores, o atendimento aos alunos, a orientação de pesquisas, as atividades de extensão, o trabalho dos servidores técnicos administrativos, o estudo e convivência dos alunos de diferentes idades, os diversos laboratórios para cada tipo de curso, para os acervos nas bibliotecas de todos os cursos oferecidos por cada campus de cada Instituto Federal.

Conforme a lei que cria os IFs, é apontado que a verticalização pressupõe otimizar a estrutura física enquanto recurso material ao expandir e ampliar as atribuições das antigas escolas técnicas significa também que a estrutura física deve dar conta de atender a todas as demandas das condições concretas de trabalho tanto da educação básica quanto da educação superior.

Sendo os Institutos Federais "uma forma híbrida entre Universidade e Cefet" (PACHECO et al. Ibidem, p. 79), concordamos com Sacristán (2000) ao afirmar que a teorização sobre o currículo "deve ocupar-se necessariamente das condições de realização do mesmo" (p. 16), ou seja, é preciso observar os limites de se atender a contento as demandas de ensino, pesquisa e extensão ao agregar em um único espaço físico dois níveis e modalidades de ensino diferentes, do ponto de vista objetivo, ou seja, das condições materiais de trabalho, as exigências específicas dos diversos níveis e modalidades de ensino. Percebe-se, a partir da verticalização e da otimização dos recursos, o adensando e superposição das funções no espaço físico de uma única instituição.

A instituição educacional é referencial de espaço real e simbólico e esse espaço “[...] jamais é neutro: em vez disso, ele carrega, em sua configuração como território e lugar, signos, símbolos e vestígios da condição e das relações sociais de e entre aqueles que o habitam" (FRAGO; ESCOLANO, p. 64, 1995) e na construção do currículo verticalizado bem como na identidade dos IFs, especialmente os novos campi que não surgiram de nenhuma escola federal, mas se materializaram, onde antes não havia nem o espaço físico, nem a tradição da educação profissional. É o caso do IFB, pois o único campus resultante de uma ETF é o campus Planaltina no qual historicamente funcionou o Colégio Agrícola de Brasília, instituição federal e, posteriormente sob a responsabilidade do GDF e, novamente, sob a responsabilidade federal. 
Todos os demais nove campi de um total de 10 que compõe o IFB são totalmente novos, não têm a história da educação profissional. Em Brasília sequer havia um CEFET, considerado a instituição base para a verticalização por já realizar nos últimos anos anteriores a sua transformação em IFs a verticalização da educação básica e do ensino superior. Conforme o atual PDI (2014) do IFB existem diferenças nas configurações arquitetônicas de cada campus, sendo uns maiores, outros menores, uns mais estruturados com mais ou menos ambientes e equipamentos de trabalho condizentes com a oferta verticalizada de seus eixos tecnológicos. A "Falta de revisão da infraestrutura do campus após entrega das obras" (p.21) foi inclusive apontada como uma fraqueza no processo de diagnóstico institucional.

Dessa maneira, o simbólico na construção da identidade dos IFs perpassa também a infraestrutura, uma vez que os relacionamentos entre pessoas e objetos acontecem na separação do espaço físico. A arquitetura escolar é elemento cultural e pedagógico, simbolizado na vida social, ou seja, um espaço digno e adequado de trabalho acrescenta prestígio aos professores e alunos, uma vez que o espaço escolar, bem como todos os elementos materiais da educação são importantes (FRAGO; ESCOLANO, Idem).

Assim, temos a "arquitetura concreta" dos IFs em contraponto à "arquitetura curricular" verticalizada da política educacional convivendo nos espaços reais e simbólicos na busca condições de trabalho adequadas e por essa identidade no trabalho docente dos professores dos Institutos Federais, pois parece que, apesar da legislação, não há clareza sobre sua função, sobre o trabalho que os docentes devem desempenhar, se estaria o foco no ensino, na pesquisa ou na extensão, e em quais níveis. Seria possível atender a todas as áreas igualmente de maneira integrada e verticalizada?

A manifestação do CONCEFET (2007) a respeito da política de criação da Rede Federal e transformação dos CEFETs em IFs referenda os Institutos Federais como instituições emancipadoras por meio da formação profissional e tecnológica, para que seus egressos trabalhem no desenvolvimento local e regional. Os IFs organizam seus currículos de acordo com as demandas dos setores produtivos ofertando cursos em sintonia com a consolidação e o fortalecimento dos arranjos produtivos locais (BRASIL, 2007b), na busca pela formação de cidadãos em uma sociedade justa, equânime e solidária (BRASIL, 2008b).

Podemos perceber que há uma compreensão na qual emancipação é entendida como o aumento da escolaridade e a cidadania é adquirida por meio de um emprego, 
este decorrente da formação da mão de obra especializada. A emancipação, nesse contexto, significa a inserção no mercado de trabalho e, consequentemente, a melhora nas condições de vida. Trata-se de um conceito diferente de emancipação humana.

Conforme Tonet (2005), em uma perspectiva marxiana, o trabalho é o fundamento do ser social, por meio do qual o sujeito desenvolve a sua sociabilidade. A cidadania faz parte da emancipação política, a qual está localizada na sociedade civil, ou seja, nas relações econômicas. Ser cidadão não é ter plena liberdade, mas ser apenas formalmente, livre, igual e proprietário. A ordem capitalista impõe uma barreira instransponível que, por mais direitos que o cidadão tenha, as desigualdades na origem não são suprimidas. A emancipação humana é então a "forma de sociabilidade na qual os homens sejam efetivamente livres, supõe a erradicação do capital e de todas as suas categorias.” (Idem, p. 3). Nessa perspectiva, não se trata de aperfeiçoar a cidadania, mas de superá-la, pois formar cidadãos é formar pessoas que vivem, se conformam e se dedicam a melhorar a sociedade regida pelo capital. Formar para a emancipação humana é superar radicalmente o capital (TONET, 2007).

Assim, o currículo verticalizado dos IFs em íntima associação e articulação com o sistema produtivo vem atender as conformações de formação de mão de obra especializada. Conforme Lopes e Macedo

Os estudos sobre políticas de currículo vêm se ampliando nos últimos anos em diferentes países, em muito influenciados pelo aumento da intervenção estatal em questões educacionais. Como aponta Ball (1998), essa intervenção tem agido no sentido de vincular a escolarização ao emprego e à produtividade, reduzindo custos da educação e controlando os conteúdos do currículo e da avaliação. (LOPES; MACEDO, 2006, p.5).

Seguindo essa mesma linha de formação, o ensino médio integrado à educação profissional (EMI) ofertado pelos IFs pressupõe a articulação entre trabalho e ensino. O currículo nessa modalidade reúne conteúdos do ensino médio e da formação profissional, os quais são trabalhados de forma integrada. Ensino integrado implica um conjunto de categorias e práticas educativas no espaço escolar que desenvolvam uma formação integral do sujeito trabalhador. A integração buscaria assim uma educação tecnológica ou politécnica no qual a educação básica necessita explicitar o modo como o conhecimento se relaciona com o trabalho (BRASIL, 2006). 
Conforme Saviani, politecnia significa a "[...] superação da dicotomia entre trabalho manual e trabalho intelectual, entre instrução profissional e instrução geral." (1989, p. 13) uma vez que não existe um trabalho puramente manual ou intelectual. A politecnia está ligada ao domínio dos fundamentos científicos das diferentes técnicas que caracterizam o processo de trabalho produtivo moderno. Saviani (2003) destaca ainda a questão do trabalho como princípio educativo geral no currículo escolar, pois o trabalho é processo por meio do qual o homem transforma a natureza. Sendo assim, a politecnia supera a dicotomia a formação profissional formação geral. Em uma concepção capitalista o ensino profissional entende a formação em especialidades autônomas para formar trabalhadores para executar de maneira eficiente as tarefas em conformidade com o mercado de trabalho.

A educação politécnica é unitária e universal e não necessariamente forma profissionais em cursos técnicos específicos, porém, uma educação universal politécnica e unitária não encontra base material concreta de sustentação na sociedade brasileira atual. A solução transitória, conforme proposta pela política educacional é ofertar um EMI que proporcione a educação básica e a formação profissional integrando essas duas dimensões (BRASIL, 2007). Ou seja, uma politecnia incompleta, uma educação que, por enquanto, eleve a escolaridade da população e prepare para o emprego.

Para a realização dessa empreitada é imprescindível que haja professores para lecionar na educação profissional. A falta de professores para atuar nesse cenário de educação básica integrada a educação profissional é reconhecida como uma falha para a oferta do EMI conforme preconizada na política educacional. A situação engloba os bacharéis docentes que atuam sem formação pedagógica e professores licenciados que não tiveram formação para o EMI. Sendo assim, idealmente, esse professor para exercer a docência nesse nível e modalidade deveria ter os conhecimentos específicos de uma área profissional, a formação didático-político-pedagógica e fazer a integração entre a EPT e a educação básica (BRASIL, Idem).

Esses são os professores que irão atuar em uma realidade pluricurricular no cumprimento de um itinerário formativo ofertado pelos Institutos Federais e os docentes iniciam seu trabalho nos Institutos Federais por meio da realização de concursos públicos. A análise documental de editais de concursos realizados na Região CentroOeste no período de 2008 a 2012 revelou que há deficiências no estabelecimento do perfil do professor que irá trabalhar nos IFs visto que, em decorrência da verticalização "na verdade esse professor está situado na fronteira entre ser professor da educação 
básica e ser professor do ensino superior." (CRUZ; VITAL, 2014, p.44) e, portanto, esses editais não atenderiam plenamente os requisitos básicos para a entrada desses profissionais no magistério. A análise dos editais reforça ainda a contratação de um perfil de professor para o ensino superior.

Foi observado que nos últimos editais entre 2010 e 2012 foram sendo delineados nas provas de títulos critérios que se aproximariam à definição de um perfil de pesquisador muito semelhante ao professor do magistério superior, o que também se justifica pela nova natureza administrativa dos institutos em serem autarquias de ensino superior. (CRUZ; VITAL, Idem, p.44).

Por se tratar de uma instituição verticalizada há incertezas sobre qual seria o perfil de professor para trabalhar no IF em termos de formação e experiência prévia com a docência. Nem os editais da mesma região concordam sobre o peso dado aos critérios que variam desde a titulação, experiência na docência, experiência em pesquisa, produção de patentes e produção bibliográfica, para citar alguns exemplos.

O inciso III do Art. 6o da Lei $\mathrm{n}^{\circ} 11.892$ define as finalidades e características dos Institutos Federais

Os Institutos Federais têm por finalidades e características: III promover a integração e a verticalização da educação básica à educação profissional e educação superior, otimizando a infraestrutura física, os quadros de pessoal e os recursos de gestão (BRASIL, 2008b).

Ao falar em finalidades e características, "a forma como está estruturado o IF prevê otimização dos custos, e total controle da nova instituição, o que pode acarretar uma fiscalização e um direcionamento mais eficaz na subordinação da educação por ela ministrada aos interesses do mercado" (OTRANTO, 2010, p. 15). Essa otimização também se refere aos trabalhadores dos Institutos Federais.

A otimização remete ao debate sobre a produtividade docente (HIRO, 2013) e maximização da produtividade acadêmica, ainda que em condições precárias de trabalho, nesse sentido, "a produtividade do trabalho docente passa pela exigência de produção científica, constituição de grupos de pesquisa, orientações de diversas naturezas, extensão universitária, além da elevada carga horária em sala de aula" (YAMANOE, 2011, p. 8) fazendo com que o trabalho docente tenha uma relação cada vez mais direta com o processo produtivo. 
Os docentes dos IFs se defrontam com a oferta educativa diversificada no âmbito dos Institutos Federais e a verticalização de

diferentes níveis e modalidades da educação profissional e tecnológica, tomando para si a responsabilidade de possibilidades diversas de escolarização como forma de efetivar o seu compromisso com todos. (BRASIL, 2008, p. 27).

Porém, os professores são os mesmos para todas as tarefas a que os IFs se propõem, realizando de forma concomitante ensino, pesquisa e extensão nos dois níveis e diversas modalidades e com público distinto, solicitando do professor uma ação polivalente e flexível. Essa condição é em nossa pesquisa denominada de polivalência por nível de ensino, o que entendemos acarretar em implicações para o trabalho docente. Conforme Cruz e Neto

O termo polivalência, por sua vez, tem sido comumente usado no contexto do mundo do trabalho, requisitado pelo discurso neoliberal no período pós-crise do capitalismo. Designa a capacidade de o trabalhador poder atuar em diversas áreas, podendo caracterizar ainda um profissional pautado pela flexibilização funcional. Esse entendimento da polivalência tem, por vezes, exercido certa influência na visão que se faz do professor/a dos anos iniciais quando há a referência de que ele tem de cumprir múltiplas funções, aproximandose assim de uma visão de profissional de competência multifuncional (CRUZ; NETO, 2012).

A polivalência supõe múltiplos saberes e a capacidade de "transitar com propriedade em diferentes áreas" (LIMA, 2007 apud CRUZ; NETO, 2012, p. 386). No contexto do ensino dos Institutos Federais, os docentes são chamados a assumir a docência polivalente em níveis e modalidades diferentes para dar conta da verticalização e otimização dos recursos previstos na lei de criação dos IFs.

Contraditoriamente, o conceito de polivalência vai de encontro ao trabalhador especializado, pois o trabalhador polivalente realiza atividade não padronizada, dificultando sua mensuração, por isso é preciso envolver a subjetividade desse trabalhador para que ele possa desenvolver seu trabalho intelectual (AMORIM, 2014).

Assim, polivalência por nível de ensino exigiria certa plasticidade (FARIAS, 1998) do docente, tornando o professor do IF em trabalhador polivalente. A educação básica e cada uma de suas distintas etapas tem cada uma delas “[...] finalidades e características próprias, tem implicações nos perfis e nas condições em que atuam os 
docentes de cada uma delas [...]" (INEP, 2007, p. 48) bem como as modalidades EJA, educação especial, cursos subsequentes, concomitantes ou integrados ao ensino médio e cursos do Proeja.

Dessa forma, o trabalho docente no contexto da verticalização não se estrutura na figura do professor especialista em educação profissional ou ensino superior, mas aquele que teria domínio amplo de conhecimentos específicos da sua área de formação, teria experiência profissional e estaria pronto a lidar com todas o eixos tecnológicos de abrangência da mesma instituição, além de ser polivalente, flexível, adaptável, produtivo, otimizado, que vai se formando e constituindo sua docência no trabalho para atender a uma lógica de reforma e expansão da educação superior, profissional e tecnológica de menor custo para o governo.

A questão da verticalização enquanto característica da institucionalidade dos IFs não está clara para os professores (SANTOS, 2005) e afeta o trabalho docente por se tornar otimizado e polivalente. Para compreensão do trabalho docente no contexto da institucionalidade verticalizada dos IFs, devemos considerá-lo na totalidade da categoria trabalho e em suas especificidades.

\subsection{A categoria trabalho}

$\mathrm{Na}$ produção da vida material, o trabalho é categoria fundante do ser social. O homem, ao nascer, carrega consigo o patrimônio genético da espécie, mas é por meio do trabalho que se humaniza. A categoria do trabalho, para Marx, é o que diferencia o ser humano do reino animal.

Antes de tudo, o trabalho é um processo de que participam o homem e a natureza, processo em que o ser humano com sua própria ação, impulsiona, regula e controla seu intercâmbio material com a natureza. [...] Atuando assim sobre a natureza externa e modificandoa, ao mesmo tempo modifica sua própria natureza" (MARX, 1989, p.202).

Distinto do animal, que apenas adapta-se à natureza, o ser humano por meio da sua ação consciente, transforma o meio natural em seu benefício. O trabalho tem, "portanto, [...] uma intenção ontologicamente voltada para o processo de humanização do homem em seu sentido amplo" (ANTUNES, 1999, p. 142). 
O homem planeja a ação antes de executá-la, trata-se da prévia ideação, ou seja, um "momento de planejamento que antecede e dirige a ação" (LESSA 1996, p. 24). Mas a prévia ideação precisa ser concretizada na prática para ser considerada como tal, a prévia ideação quando se materializa, torna-se objetivação. No entanto, o objeto previamente idealizado e objetivado não pode ser confundido com o sujeito detentor da prévia ideação. Essa "distinção entre o sujeito, portador da prévia-ideação, e o objeto criado no processo de objetivação, Lukács denominou alienação (Entäusserung)". Para Lukács, Ser humano "significa uma crescente capacidade de objetivar/alienar - isto é, transformar o mundo segundo finalidades socialmente postas" (LESSA, Ibid. p. 26). O trabalho é então, componente fundante da sociabilidade humana, enquanto processo histórico é a "[...] utilização e transformação progressivamente mais eficazes da natureza pela humanidade [...]" (HOBSBAWN, 1998, p. 173).

O trabalho, enquanto gênese do ser social existe para responder a situações concretas das necessidades do ser humano. O conhecimento histórico acumulado possibilita "a continuidade da reprodução do mundo dos homens" (LESSA, op. cit., p. 61). De acordo com o momento social o trabalho tem diferentes significados e, sendo determinado, "assume formas históricas específicas nos diferentes modos de produção da existência humana" (FRIGOTTO, 2009). No sistema de produção capitalista, no qual os homens se dividem em detentores e não detentores dos meios de produção, o trabalho se assume como mercadoria, uma vez que aqueles que não detêm os meios de produção nada mais possuem além da sua própria força de trabalho. Dessa forma, o capital acumula-se em poucas mãos, e os trabalhadores vendem a única coisa que possuem. Os produtos desse trabalho sob a condição da expropriação não pertencem ao trabalhador, mas ao capitalista. Esse tipo de trabalho, no sentido econômico (KOSIK, 2002) não mais se configura como humanização do homem, mas como alienação.

Nesse sentido, trabalho é diferente de emprego. O trabalho enquanto princípio ontológico de humanização do homem é distinto do trabalho realizado sob o modo de produção capitalista, na forma de emprego ou trabalho assalariado. O capitalista detém a força de trabalho, pois a adquiriu no mercado, assim "o trabalhador trabalha sob controle do capitalista, a quem pertence seu trabalho" (MARX, 1989, p. 209). Em um sistema determinado pela divisão social do trabalho, a força de trabalho é mercadoria que o trabalhador vende em troca de uma quantidade de meios de subsistência, eliminando sua autonomia. Assim, “Ao apropriar-se individualmente de objetos naturais para prover sua vida, é ele (o trabalhador) quem controla a si mesmo; mais tarde, ficará 
sob o controle de outrem" (MARX, Ibid., p. 584). O trabalho, antes uma forma de humanização do ser social, passa a ser fonte de alienação e desumanização.

Ao tratar sobre trabalho assalariado, a classe trabalhadora é um conceito presente na obra de Marx e que foi ampliado por Antunes (1999) utilizando a expressão classe-que-vive-do-trabalho, ou seja, todo aquele que vende sua força de trabalho, e que engloba o trabalho assalariado. Essa classe que vive do trabalho incorpora tanto os trabalhadores produtivos - aqueles que produzem mais-valia e valorizam diretamente o capital - quanto os trabalhadores improdutivos - aqueles cujo trabalho é consumido como serviço -, seja para uso público ou para o capitalista.

Sobre o trabalho produtivo, Marx afirma que

\begin{abstract}
A produção capitalista não é apenas produção de mercadorias, ela é essencialmente produção de mais valia. $O$ trabalhador não produz para si, mas para o capital. Por isso não é mais suficiente que ele apenas produza. Ele tem de produzir mais valia. Só é produtivo o trabalhador que produz mais valia para o capitalista, servindo assim à autoexpansão do capital (MARX, 1989, p. 584).
\end{abstract}

O trabalho improdutivo é também trabalho, porém, não gera valor

Nas esferas de circulação, distribuição e consumo, a teoria é clara em estabelecer que o valor não e produzido, e sim redistribuído. Assim o trabalho em atividades comerciais e atividades que permitem o consumo das mercadorias não produz novos valores, somente permite a circulação e a realização de valores já criados (DAL ROSSO, 2014).

O trabalhador improdutivo está em franca expansão no capitalismo contemporâneo e envolve uma massa de assalariados do setor de serviços, tais como bancos, comércio e serviços públicos.

No modo de produção capitalista, as alterações no mundo do trabalho, referentes às concepções de trabalho como princípio ontológico acometem o sistema econômico, político e influenciam a organização de toda uma sociedade, inclusive a organização do sistema educacional como um todo e, particularmente, do trabalho escolar, enquanto parte integrante do setor de serviços. Nessas circunstâncias, a gestão educacional se aproxima de uma administração gerencial ignorando as especificidades das instituições de ensino, bem como a natureza do trabalho pedagógico (OLIVEIRA; MORAIS; DOURADO, 2005). O trabalho docente, como parte constituinte da totalidade do trabalho no capitalismo, está sujeito também a sua lógica de exploração e contradições. 


\subsection{Trabalho docente}

$\mathrm{Na}$ produção da sua existência, o homem busca antes de tudo a sua sobrevivência material, assim a produção de bens materiais se torna cada vez mais elaborada. Essa produção, na qual o homem planejou antecipadamente representando mentalmente os objetivos reais da sua atividade é considerada trabalho material. A "representação inclui o aspecto de conhecimento das propriedades do mundo real (ciência), de valorização (ética) e de simbolização (arte)." (SAVIANI, 1984, p. 1). A produção de conhecimentos, ideias, conceitos, valores, símbolos, atitudes, habilidades são consideradas trabalho não material. Mas o trabalho não material se divide em duas modalidades. Quando o produto se separa do produtor, no caso de um objeto artístico ou livro existe um intervalo entre produção e consumo. Na segunda modalidade o produto não se separa do ato de produção, não existe o intervalho entre o ato de consumir e produzir, pois eles estão imbricados, como é o caso da educação.

Sobre a produção imaterial Marx explica que

A produção imaterial, mesmo quando se dedica apenas à troca, isto é, produz mercadorias, pode ser de duas espécies:

1 Resulta em mercadorias, valores de uso, que possuem uma forma autônoma, distinta dos produtores e consumidores, quer dizer, podem existir e circular no intervalo entre produção e consumo como mercadorias vendáveis, tais como livros, quadros, em suma, todos os produtos artísticos que se distinguem do desempenho do artista executante. A produção capitalista aí só é aplicável de maneira muito restrita [...]

2. A produção é inseparável do ato de produzir, como sucede com todos os artistas executantes, oradores, atores, professores, médicos, padres etc. Também aí o modo de produção capitalista só se verifica em extensão reduzida e, em virtude da natureza dessa atividade, só pode estender-se a algumas esferas. (MARX, 1987, p.405)

A educação, enquanto prestação de um serviço está assim localizada na forma da produção não material, não separando o produto do seu processo de sua produção, como acontece, por exemplo, em uma sala de aula. Essa é uma característica própria do trabalho docente. Os professores de instituições públicas - objeto desta pesquisa - são trabalhadores assalariados, vendem sua força de trabalho para uma instituição educacional estatal - são, portanto, classe que vive do trabalho - prestadores de um serviço, que é a educação pública, dessa forma, realizam trabalho improdutivo e não material. 
A ação primordial de um professor, o que caracteriza seu trabalho precípuo é ensinar algo a alguém (ROLDÃO, 2007) e tendo o ensino na base do seu trabalho, o professor que atua no serviço público "vende sua força de trabalho para uma instituição, que passa a determinar seu trabalho em todas as dimensões, retribuindo-o por meio de um salário; nessa situação, o trabalho tende a ser controlado, intensificado, precarizado e, portanto, mais explorado [...]" (KUENZER; CALDAS, 2009, p. 25). Mesmo no serviço público estatal os professores são submetidos a uma lógica de mercado na gestão empresarial da educação, dessa forma, o seu trabalho ainda assim pode ser superexplorado. A autonomia do trabalho docente, nesse contexto, é limitada pelas próprias condições de trabalho, na qual

\footnotetext{
Então caímos em situação análoga àquela que Marx se refere sobre a dupla liberdade do trabalhador: o professor possui uma dupla autonomia, que se expressa, por um lado, pela autonomia de exercer sua criatividade sem tempo para o planejamento, dada a intensificação de sua jornada, e por outro lado, a autonomia de planejar aulas com sua baixa qualificação, de fato. (MIRANDA, 2006, p. 43).
}

O fato de o trabalho docente ser não material significa que há mais espaço para a resistência e autonomia do trabalhador. O trabalho docente vive uma contradição entre as condições de sua realização e o prazer e o compromisso com um quadro de políticas públicas onde há redução de investimentos em educação e aumento das exigências sobre o papel da escola. Em todo tipo de trabalho há o dispêndio de "[...] energias físicas, intelectuais e afetivas" (DAL ROSSO, 2014, p. 80), e sendo trabalhadores não materiais existe uma carga extra de sofrimento psíquico ao qual estão submetidos.

Assim, a dialética prazer-sofrimento é um elemento presente no trabalho docente. Conforme Mendes (et. alii, 2006) as fontes de prazer no trabalho docente geralmente estão contidas no processo de amadurecimento do aluno, quando o professor percebe o sucesso de seus discentes anos depois ao saber que parte dessa contribuição foi dele, professor. Ainda de acordo com os autores, as fontes de sofrimento são inúmeras, passando desde o não reconhecimento da profissão, atreladas à instituição e ao processo de gestão burocrática na forma de falta de recursos, lentidão no processo burocrático, obrigações impostas pela escola, incômodos causados no processo de trabalho, incompatibilidade entre a estrutura da instituição e a capacitação dos professores. 
Essas questões nos remetem às condições de trabalho, que são entendidas como meios para ocorrer o trabalho de maneira satisfatória. Podemos considerar "[...] meios de trabalho em sentido lato todas as condições materiais seja como for necessárias à realização do processo de trabalho. Elas não participam diretamente do processo, mas este fica sem elas total ou parcialmente impossibilitado de concretizar-se" (MARX, 1989, p. 205). Assim, conforme indicaram as pesquisas analisadas, nem todos os campi dos IFs oferecem aos professores condições materiais de trabalho para cumprir com as determinações que lhes são exigidas. Considerando as condições de trabalho dos professores no Instituto Federal, a verticalização poderia unir o melhor de dois mundos - da Educação Básica e Superior - mas ao mesmo tempo impõe excesso de funções e tarefas aos seus docentes, levando a intensificação desse trabalho.

A intensificação do trabalho "representa uma das formas tangíveis pelas quais os privilégios de trabalho dos trabalhadores educacionais são degradados." (KUENZER; CALDAS, 2009, p. 35) e as implicações para o trabalho docente são muitas com cada vez mais sobrecarga de atividades para cumprir. A condição de intensificação do trabalho se traduz em mais esforço físico, intelectual e emocional com a finalidade de produzir mais resultados, consideradas constantes a jornada, a força de trabalho e as condições técnicas. O trabalho é intensificado por meio do alongamento das jornadas; ritmo e velocidade; acúmulo de atividades; polivalência, versatilidade e flexibilidade; e, gestão por resultados (DAL ROSSO, 2008).

Codo (1999) chama de carga mental do trabalho a ampliação do tempo de trabalho e a diversificação de tarefas, além da fragmentação do trabalho, preponderante em profissionais que trabalham em mais de um nível de ensino, como é o caso dos IFs verticalizados, o que pressupõe maior esforço de adaptação entre ambientes diferentes e preparação de atividades distintas, podendo gerar exaustão.

Nos IFs é possível perceber características da intensificação do trabalho docente por meio dos cinco meios citados por Dal Rosso e a partir das pesquisas previamente analisadas no estado do conhecimento, a saber: o alongamento das jornadas de trabalho pode ser percebido nas atividades que os professores levam para casa, atitude bastante comum no meio docente como planejamento de aulas, preenchimento de diários e correção de provas. O acúmulo de atividades é constatado no desenvolvimento das atividades de ensino, da pesquisa e da extensão no nível básico e superior, além daqueles docentes que assumem cargos de gestão em seus campi. A polivalência pode ser verificada no que denominamos como polivalência por nível de ensino, ou seja, 
professores que assumem o ensino na verticalização dos Institutos Federais, atendendo a uma diversidade de níveis e modalidades que vão do Ensino Médio Integrado ao Ensino Médio Concomitante, cursos FIC, cursos de nível superior tanto na licenciatura, bacharelado quanto tecnólogo, cursos de educação a distância, cursos de pós-graduação, programas como Proeja, entre outras atividades. A versatilidade e a flexibilidade podem ser observadas na trabalho em diferentes cursos e áreas de atuação de um IF, independente da formação ou experiência profissional daqueles docentes. A gestão por resultados vem das cobranças de resultados padronizados para todos os IFs por meio da sua lei de criação, que estabelece os percentuais mínimos que devem ser cumpridos para atingir os objetivos, além das demandas de órgãos de controle e de cada Plano de Desenvolvimento Institucional $^{24}$ dependendo do estágio de implantação em que o IF se encontra.

O discurso oficial, feito por aqueles que pensam a política, enxerga o professor que irá trabalhar no contexto da verticalização da seguinte forma:

Ora, é evidente que esse modelo curricular exige mudanças no perfil do profissional docente inserido na Rede, pois lidar com o conhecimento de forma integrada e verticalizada exige a superação do "modelo hegemônico disciplinar" e a construção do perfil de um profissional docente capaz de "desenvolver um trabalho reflexivo e criativo e promover transposições didáticas contextualizadas que permitam a construção da autonomia dos educandos" (BRASIL, 2008b, p. 28) (PACHECO; PEREIRA; SOBRINHO, 2010, p. 81).

Parafraseando Cruz e Neto (2012), a retórica eloquente do discurso oficial descreve os predicados da verticalização e responsabiliza o professor dos IFs para que ele seja criativo o suficiente para dar conta de múltiplos currículos desde a educação básica ao ensino superior em uma instituição que se equipara, em alguns aspectos, a uma universidade e, em outros, a uma escola de educação básica, técnica e tecnológica. Mas quais as condições concretas de trabalho nas quais se realizam essa verticalização ou essa docência polivalente? Qual a distância entre a verticalização ideal e a real?

\footnotetext{
${ }^{24}$ Trata-se de um documento exigido pelo MEC para o reconhecimento dos cursos superiores que uma instituição oferta. Também é encarado, no caso do IFB, como uma peça de planejamento institucional e que envolve também os demais cursos da educação básica.
} 


\subsection{O trabalho docente no Instituto Federal de Brasília}

O Plano de Desenvolvimento Institucional do IFB afirma que a instituição "é mais que uma IES. Aqui se oferta a formação profissional desde a sua iniciação até a pós-graduação" (IFB, 2014, p. 18). O PDI trata-se de um documento obrigatório para as Instituições de Educação Superior, mas no caso de um IF, por sua característica de verticalização do ensino, ele termina por abordar todos os segmentos que o compõem.

O Instituto Federal, por ter natureza jurídica de autarquia, é detentor de autonomia administrativa, patrimonial, financeira, didático-pedagógica e disciplinar. Dessa forma, o IFB tem dispositivos internos para organizar o seu funcionamento. Este é o caso da Portaria RIFB n²4 de 2009 que estabelece a distribuição da carga horária didática semanal dos docentes do IFB por tipo de atividade. Essa portaria passou por um processo de atualização e para essa tarefa foi instituída uma comissão formada por servidores do IFB, incluindo docentes e membros da gestão que, entre outras atividades, realizou consulta pública para que os professores pudessem sugerir alterações no documento.

O documento esteve em consulta pública no site ${ }^{25}$ do Instituto Federal de Brasília e, por meio de formulário próprio, foi possível fazer contribuições ao documento. A comissão sistematizou essas contribuições e ofereceu uma avaliação para cada sugestão apresentada. A avaliação da comissão sobre as sugestões poderia resultar em "acatada", "rejeitada", "acatada em parte" e "acatada com alteração". A nova resolução propõe a seguinte distribuição da carga horária didática semanal dos docentes do IFB por tipo de atividade

Art. $6^{\circ}$. O docente do IFB contratado em regime de trabalho de 40 horas semanais, e 40 horas semanais com dedicação exclusiva deverá ter sua carga horária semanal distribuída em dois turnos diários consecutivos, de acordo com os seguintes tipos de atividades:

I. Aula (A): mínimo de 8 horas e máximo de 15 horas (18 aulas de 50 minutos);

II. Manutenção do Ensino (ME): 8 horas

III. Apoio ao Ensino (AE): mínimo de 5 horas e máximo de 12 horas;

IV. Pesquisa e Inovação, Extensão e Formação Continuada (PIEF): 12 horas.

$\S 1^{\circ}$. Excepcionalmente e em comum acordo com o docente, os turnos de trabalho poderão ser flexibilizados.

$\S 2^{\circ}$. O docente em Cargo de Direção (CD), em Função Gratificada

(FG), ou em Função de Coordenação de Curso (FCC) poderá ministrar

${ }^{25}$ http://ifb.edu.br/ 
até o limite máximo de oito aulas, observadas as necessidades do IFB, desde que não haja comprometimento do perfeito exercício do cargo ou função, ficando dispensado das demais atividades previstas no Art. $6^{\circ}$ desta Resolução. (IFB, 2015, p.23).

Os documentos produzidos pela comissão estão disponíveis no mesmo site do IFB, no qual foi possível acessá-los para destacar alguns pontos importantes sobre a opinião dos docentes a respeito de um documento que interessa diretamente a eles, pois organiza seu trabalho dentro da instituição. Do campus Planaltina veio a sugestão para que a carga horária em sala de aula fosse delimitada em um mínimo de 8 horas e um máximo de 12 horas. A justificativa para essa alteração foi

"Considerando as políticas de incentivo à ciência e tecnologia dos Institutos Federais, sobretudo aquelas aplicadas no Instituto Federal de Brasília (IFB), e ainda, a possibilidade de incrementar o aporte financeiro para pesquisa nos Campi do IFB, considero muito relevante a alteração do Artigo. O envolvimento com pesquisa viabilizará melhores estruturas para o desenvolvimento das atividades de ensino, teórica e, principalmente, práticas no IFB” (IFB, 2015, p. 24).

A proposta foi rejeitada pela comissão com o argumento de que

Segundo a Portaria MEC 475/87, que estabelece normas complementares para o decreto 94.664/1987, o máximo de carga horária permitida para o docente de magistério superior é de $50 \%$ do total de horas do regime de trabalho nos casos de $40 \mathrm{~h}$ e $40 \mathrm{~h} \mathrm{DE}$, e de $60 \%$ para os casos de 20 horas. Isso significa o máximo de $20 \mathrm{~h}$ de aula para docente em regimes de $40 \mathrm{~h}$ e DE, e $12 \mathrm{~h}$ de aula para docentes em regime de $20 \mathrm{~h}$. Para o ensino básico temos os máximos de aula de $60 \%$ da carga horária do respectivo regime de trabalho, ou seja, $24 \mathrm{~h}$ de aula para docentes em regime de $40 \mathrm{~h}$ ou $40 \mathrm{~h}$ DE e $12 \mathrm{~h}$ de aula para docentes em regime de $20 \mathrm{~h}$. Como o regime estabelecido na proposta está abaixo do máximo permitido, a comissão entende que o limite máximo de $15 \mathrm{~h}$ de aula é razoável tendo em vista as limitações colocadas pelo Termo de Acordo de Metas, e pela estrutura de pessoal (60 docentes para cada 1200 alunos equivalentes, conforme Portaria SETEC/MEC n. 25/2015) previstas para a $2^{\mathrm{a}}$ e $3^{\mathrm{a}}$ fase da expansão dos institutos (exceto campus capital e campus agrícola) (IFB, 2015, p. 24).

Diversos outros campi sugeriram a redução da carga horária docente com argumentos semelhantes, assinalando que os professores estão sobrecarregados com atividades de ensino, dificultando a realização de outras atividades inerentes às suas funções no IFB. 
O campus Brasília também sugeriu um limite menor para a carga horária dos professores e que não ultrapassasse 16 horas e ainda propôs uma divisão de carga horária entre os professores que contemplasse o nível de complexidade entre os cursos, por exemplo, professores que lecionam nos FICs teriam carga horária maior e professores que lecionam na pós-graduação carga horária menor, pois implicaria em atividades como orientação individual de alunos. A proposta foi rejeitada pela comissão com o argumento de que "Na prática, os docentes não poderão atuar em apenas um nível de ensino. E não há consenso de que o os diferentes níveis de ensino reflitam necessariamente diferenças de complexidade" (IFB, 2015, p. 27).

O campus Brasília sugeriu alterar a carga horária destinada a Manutenção do Ensino (ME) para um a proporção (como dois terços ou um terço) da carga horária efetivamente dedicada à Aula (A). A mesma proposta veio também do campus Planaltina com a justificativa de que "Não é justo o professor que tem a carga horária máxima de 18 aulas ter o mesmo ME que um professor que tem carga horária de apenas 8 horas/aula" (IFB, Ibid., p.30). As propostas foram rejeitadas pela comissão com o mesmo argumento de que

\footnotetext{
"Os casos onde o docente está com pouca carga horária deve ser temporário, ficando o campus responsável por se planejar para resolver esse problema. A proporcionalidade poderia resolver as injustiças de quem possui poucas aulas, mas não de quem possui diferentes disciplinas/turmas atribuídas demandando grande tempo de preparação didática mesmo com carga horária abaixo do razoável" (IFB, 2015, p. 27).
}

Essa situação reflete um dos problemas de um IF ou campus em implantação que é a disparidade na divisão da carga horária entre professores, sobrecarregando alguns docentes e áreas mais demandadas pelos cursos de cada campus.

Uma proposta vinda do campus Planaltina ressaltou a diversidade e heterogeneidade de condições que os alunos chegam ao IFB

"Muitos professores apresentam projetos pedagógicos de letramento, nivelamento de disciplina, técnicas de redação, educação financeira, educação sexual e saúde que poderiam estar sendo contemplados com carga horária assim como os Projetos de Pesquisa e Extensão são contemplados. Cabe ressaltar que temos alunos que chegam aos campi com demandas muito heterogêneas e os Projetos Pedagógicos podem nos auxiliar nessas demandas. Além disso, é uma forma de valorizar o professor que se dedica mais ao ensino propriamente dito. Por fim, tal item irá resultar em registros de atividades que combatem a evasão 
escolar, nos auxiliando perante as análises das auditorias" (IFB, 2015, p. 29).

A comissão ressaltou que essas atividades podem ser contempladas no que se chamam Atividades de Apoio ao Ensino (AE). O que podemos perceber é que se um professor tiver a carga horária máxima de 18 horas em sala de aula e realizar 12 horas de apoio ao ensino, ele ficará impossibilitado de realizar pesquisa e extensão, a menos que exceda seu tempo de trabalho de 40h semanais.

Os docentes do campus Planaltina sugerem que o número de componentes curriculares diferentes ministrados por docente não deverá exceder o limite de quatro. A justificativa para isso vem daqueles que vivem a verticalização no campus, uma vez que ministram aulas no curso superior de tecnologia em Agroecologia e técnico em agropecuária (subsequente e integrado), "acredito que seja pedagogicamente inviável a docência de mais de quatro componentes curriculares diferentes por professor" (IFB, Ibid., p. 31). O professor segue afirmando que

o número acima de quatro componentes curriculares por docente prejudica a qualidade da aula e o processo de ensino aprendizagem; devido à limitação do tempo necessário para preparação didática de cada componente curricular. Além disso, a complexidade dos conteúdos ministrados no ensino superior também requer um tempo maior de preparação didática (IFB, 2015, p. 31).

Os professores que lecionam nos cursos superiores argumentam mais uma vez sobre o grau de dificuldade que esse nível tem representado para eles no sentido do planejamento das atividades. São docentes que estão vivenciando a polivalência por nível de ensino, uma vez que lecionam em dois níveis e sentem as complicações causadas pela sobrecarga de múltiplos componentes curriculares distintos. A comissão também rejeitou tal proposta afirmando que

Nos casos onde o docente possui, por exemplo, 4 componentes curriculares de 2 aulas cada, o docente ficaria limitado a dar 8 aulas permanentemente. Isso acarretaria a necessidade de contratação outro servidor o que geraria um problema muito grande para a administração, pois o limite é de 60 docentes por campus em média. (IFB, 2015, p. 32).

Com uma estrutura enxuta e otimizada, os professores do IFB não têm opção a não ser assumir uma variedade de componentes curriculares e em cursos diferentes. $\mathrm{Na}$ lei de criação dos IFs, Art. $20 \S 1^{\circ}$, para efeito da incidência das disposições que regem 
a regulação, avaliação e supervisão das instituições e dos cursos de educação superior, os Institutos Federais são equiparados às universidades federais. Considerando que os Institutos Federais, conforme o Decreto $\mathrm{n}^{\circ} 5.773$ de 2006, no que se referem à regulação, supervisão e avaliação serão tratados como instituições de educação superior, depreende-se que, para serem avaliados de maneira equivalente, os professores deveriam ter as mesmas condições de trabalho de seus pares nas universidades federais.

O que existe atualmente é um sistema de avaliação único para os cursos superiores, o Sistema Nacional de Avaliação da Educação Superior (SINAES) tratando como iguais instituições que funcionam em situações diversas. Os instrumentos avaliativos do SINAES não atendem às especificidades dos IFs, uma vez que essas especificidades são o que caracterizam a identidade dos Institutos Federais.

O documento de Análise das Contribuições da Comunidade pela comissão do IFB segue com vários outros comentários sobre a sobrecarga de trabalho docente e propostas para minimizá-la.

Tanto a proposta de alteração quanto a atual Resolução RIFB nº. 24/2009, que regula a carga horária docente no IFB refuta de toda maneira a possibilidade de que os professores tenham mais do que 8 horas semanais para o planejamento das aulas e todas as outras atividades que resultam do ensino (elaboração e correção de atividades de avaliação, preenchimento de diários, planejamento das aulas, leituras para as aulas, entre outros). O resultado disso é o indicativo de intensificação do trabalho para dar conta de todas essas atividades imprescindíveis ao ensino ou a utilização do tempo que deveria ser de pesquisa e extensão para esse propósito. A fala de um dos professores no documento apresentado pela comissão dá a dimensão da sobrecarga

Alguns professores com 18 horas/aula estão esgotados. A qualidade das aulas fica comprometida. Um professor que tem 4 componentes diferentes continua com a mesma quantidade de horas para atender alunos e preparar suas aulas. Isso é simplesmente improdutivo. (IFB, 2015, p. 40).

O parecer jurídico da Procuradoria Geral da União junto ao IFB sobre a minuta de resolução proposta pela comissão sugere que "a prioridade de distribuição de carga horária docente deve ser dada às atividades de ensino" (AGU, 2015, p. 3), o que é acatado pela comissão que deixa claro que as aulas são priorizadas em relação às outras atividades. Fica evidente que a função primordial do professor do IFB é estar em sala de aula, ao contrário de haver um equilíbrio entre ensino-pesquisa-extensão, numa clara 
ingerência de um órgão externo na autonomia garantida em lei para os IFs e justificativa para a própria verticalização.

A contradição se revela na quantidade de atribuições e exigências que se faz desse profissional para além da docência propriamente dita. O que parece resultar com essas determinações é um professor que leciona no nível superior, mas que não realiza pesquisa, pois não há tempo, um professor que desenvolve programas de extensão e pesquisa aplicada, mas não tem as condições para o que propõe a lei que criou os IFs.

Acompanhar a substituição da resolução que regulamenta a carga horária docente bem como as considerações feitas tanto pelos campi quanto pela comissão são indicativos de uma tendência que deve se manter nas condições de trabalho docente no IFB. Além da intensificação do trabalho docente, a consequência dessa sobrecarga é a baixa produtividade de pesquisa, conforme indicou recente estudo da Fundação Joaquim Nabuco. Os resultados da pesquisa deixam claro que uma das principais causas para essa situação é o requerimento no tempo dos professores em atividades de ensino, assim

Os IFs não fazem, na maioria dos seus campi, pesquisa tecnológica, nem transferem tecnologia, por falta de incentivo específico e pela grande demanda para atividades de ensino, agravada por ser simultaneamente em diferentes níveis (básico, superior e profissional), que exigem diferentes formas de comunicação e técnica pedagógica e em alguns casos por exceder a competência de ensino adquirida pelos novos professores em seus cursos de graduação e pós-graduação que não preveem o exercício do ensino fundamental. (TÁVORA et al., 2015, p.11).

As conclusões da pesquisa destacam ainda as condições de trabalho como a "deficiência na estrutura de apoio, como laboratórios" e a "drenagem de tempo e energia" que impede o cumprimento das determinações da Lei que criou os IFs. Os pesquisadores recomendam a alocação de um tempo máximo de carga horária no ensino que seja compatível com o desafio da tarefa que se propõe.

Atualmente, no IFB, o tempo máximo que um docente pode ter destinado à docência é de 20h, o que se mostra incompatível com a realização de atividades de pesquisa e extensão sem extrapolar o horário de trabalho. Um agravante dessa carga horária excessiva em sala de aula é o fato de que os Institutos Federais têm seus cursos superiores avaliados, regulados e supervisionados da mesma forma que as universidades federais, ou seja, condições de trabalho docente bastante diferentes são tratadas como iguais. 
O SINAES traz em seus instrumentos de avaliação da qualidade dos cursos superiores questões relativas à infraestrutura das instituições. Essa avaliação se vale de instrumentos padronizados e envio de comissões de especialistas às instituições que oferecem cursos superiores. As comissões de avaliadores caracterizam-se pela visita in loco aos cursos e instituições públicas e privadas e se destinam a verificar as condições de ensino, em especial aquelas relativas ao perfil do corpo docente, as instalações físicas e a organização didático-pedagógica.

A expansão acelerada dos IFs, incluindo o IFB, resultou em campi funcionando em espaços provisórios, em prédios alugados ou cedidos para dar início ao funcionamento dos campi em locais não apropriados a uma instituição educacional, em muitas situações havendo inclusive a convivência com obras inacabadas, como é o caso do campus Brasília e outros, conforme o PDI (2014).

O instrumento do SINAES que guia a avaliação de cursos superiores é dividido em três dimensões: a primeira dimensão trata da organização didático pedagógica, a segunda dimensão trata do corpo docente e a terceira dimensão trata das instalações físicas da unidade educacional. Sobre a avaliação das instalações físicas, não há nenhuma diferenciação entre os quesitos exigidos para as universidades e os Institutos Federais. Os IFs, para que tenham seus cursos autorizados, reconhecidos ou renovados devem ter uma estrutura equivalente a de uma universidade.

A dimensão $n^{o} 3$ é dividida em indicadores que vão desde as condições da sala de professores e de gabinetes de trabalho para professores. Sobre esse último indicador, podemos citar como exemplo o item 3.1.2 Gabinetes de trabalho para professores refere-se a um elemento que não consta na arquitetura do IFB. A avaliação vai adiante ao tratar da disponibilidade de laboratórios de informática para os alunos, que diante da otimização dos espaços são compartilhados por todos os alunos de todos os níveis e modalidades. Ainda de acordo com o PDI (Ibidem) do IFB, os campi estão organizando suas bibliotecas à medida que a infraestrutura provisória é substituída pela definitiva e adquirindo a bibliografia dos cursos, não se mostrado satisfatórias em alguns casos para atender toda a demanda dos cursos oferecidos.

Há ainda outro fator relativo à quantidade de componentes curriculares para cada docente. Para que se obtenha nota máxima na avaliação do INEP, o docente deve ter a média de componentes curriculares menor que três, fato que em uma estrutura de IF não é realmente viável diante da necessidade de verticalizar e otimizar os recursos humanos. A avaliação dos cursos superiores segue ainda colocando nota máxima para os docentes 
que apresentam em um período de três anos pelo menos duas produções e o pleno desenvolvimento de pesquisa com a participação de estudantes de iniciação científica. Com a carga horária voltada praticamente para a docência não é difícil entender a razão da baixa produtividade acadêmica docente nos IFs (DIAS, et. al. 2016).

Nesse contexto, prosseguimos a análise do trabalho docente na verticalização da educação profissional e tecnológica a partir da compreensão dos professores do IFB. 


\section{TRABALHO DOCENTE NA VERTICALIZAÇÃO: AS CONCEPÇÕES DOS PROFESSORES}

"O conhecimento científico é sempre uma busca de articulação entre uma teoria e a realidade empírica; o método é o fio condutor para se formular esta articulação."

(MINAYO; SANCHES, 1993).

Este capítulo tem como objetivo apresentar e discutir o trabalho docente a partir das concepções dos professores do IFB a respeito da política pública educacional que criou os Institutos Federais e a característica da verticalização. Essa singularidade dos Institutos Federais propõe que haja uma integração da educação básica à superior, fazendo com que os professores tenham de trabalhar na articulação desses diferentes níveis, currículos e públicos distintos. Discutimos ainda as condições de trabalho nos campi que compõem o IFB, os limites e as possibilidades do trabalho docente que vem sendo desenvolvido na verticalização e integração da educação básica à superior, além da visão de representante sindical sobre o trabalho e a formação dos professores do Instituto Federal de Brasília.

Uma fase da coleta de dados para a pesquisa foi realizada por meio de questionários e entrevistas e se deu no próprio Instituto Federal de Brasília, espaço geográfico e social delimitado pelas instituições que compõem o IFB, mais especificamente seus campi localizados no Distrito Federal. Da população em questão, foi selecionada uma amostra representativa em termos quantitativos, uma vez que o IFB é composto atualmente por $529^{26}$ Professores do Ensino Básico, Técnico e Tecnológico divididos em dez campi, dos quais responderam aos questionários 80 professores de nove campi, representando $15 \%$ dos docentes.

A população analisada é o "conjunto de elementos que formam o universo de nosso estudo e que são passíveis de serem observados. Uma parte destes elementos é dita uma amostra." (BARBETTA, 2002, p.13). Dentre essa amostra pesquisada foram escolhidos oito professores para entrevistas, o que representa uma amostragem ilustrativa dessa população. Desta forma, o "estudo quantitativo pode gerar questões para serem aprofundadas qualitativamente, e vice versa." (MINAYO; SANCHES, p.

\footnotetext{
${ }^{26}$ Dados obtidos no site http://ifbemnumeros.ifb.edu.br/ na data de 7/8/2016, no item "Servidores por cargo e local de lotação no IFB", considerando professores efetivos, substitutos e temporários.
} 
247, 1993), uma vez que os professores que participaram desta pesquisa representam razoavelmente bem a população de onde foram extraídos.

O questionário utilizado na pesquisa, o termo de consentimento livre e esclarecido, bem como os roteiros das entrevistas realizadas para cada segmento docente encontram-se como Apêndice desta dissertação.

\subsection{Itinerário e instrumentos utilizados: questionário e entrevistas}

Tanto as entrevistas quanto a aplicação dos questionários foram realizadas no $1^{\circ}$ semestre de 2016, no próprio local de trabalho dos docentes. Os professores tiveram acesso ao termo de consentimento livre e esclarecido que garante inclusive o anonimato das informações declaradas. Por essa razão, a identidade dos entrevistados e dos que responderam aos questionários foi preservada com o uso de siglas para identificar suas opiniões.

\subsubsection{Questionário}

O questionário utilizado nesta pesquisa foi resultado de uma construção coletiva que envolveu discussões e análises de alunos e professoras da graduação e pósgraduação participantes no Grupo de Estudos e Pesquisas sobre Formação e Atuação de Professores/Pedagogos (GEPFAPe) e faz parte de uma pesquisa mais ampla sobre a profissionalidade docente na educação profissional ${ }^{27}$. Por isso, algumas perguntas foram pensadas para esta pesquisa sobre o trabalho docente na verticalização e selecionadas para análise nesta dissertação.

O questionário representa um instrumento de coleta de dados constituído por uma série ordenada de perguntas que foram respondidas por escrito pelos professores do IFB sem a presença da pesquisadora e contou com perguntas abertas, fechadas e mistas. As perguntas abertas possibilitaram aos professores responderem livremente sobre o assunto pesquisado, enquanto nas perguntas fechadas os sujeitos deveriam escolher entre as opções indicadas as suas respostas, já nas perguntas mistas os professores

\footnotetext{
${ }^{27}$ Pesquisa: A construção da profissionalidade docente bacharéis na educação profissional e tecnológica, aprovada na Chamada pública MCTI/CNPq/MEC/CAPES nº 43/2013.
} 
tiveram a oportunidade de escolher entre as opções de respostas e justificar as escolhas com suas considerações a respeito (GERHARDT; SILVEIRA, 2009).

O questionário foi respondido de maneira voluntária e os professores foram comunicados de que as informações fornecidas seriam mantidas em sigilo, inclusive não sendo necessária a identificação nominal do respondente. Dessa maneira, cada professor mencionado durante o texto é identificado com um numeral e a sigla do seu campus de origem.

As siglas que identificam os campi são as seguintes: Campus Brasília - CBRA, Campus Ceilândia - CCEI, Campus Gama - CGAM, Campus Planaltina - CPLA, Campus Riacho Fundo - CRFU, Campus Samambaia - CSAM, Campus São Sebastião - CSSB, Campus Taguatinga - CTGT, Campus Taguatinga Centro - CTGC.

O critério de seleção dos sujeitos para responder aos questionários é que se tratasse de professor EBTT vinculado ao IFB - de maneira efetiva ou temporária - e assim, suscetível à política de verticalização dos Institutos Federais. O quadro a seguir indica a quantidade de questionários respondidos em cada campus participante da pesquisa:

Quadro 4: quantidade de questionários respondidos em cada campus

\begin{tabular}{|c|c|}
\hline Campus: & Quantidade de questionários respondidos: \\
\hline Brasília & 6 \\
\hline Ceilândia & 6 \\
\hline Gama & 4 \\
\hline Planaltina & 5 \\
\hline Riacho Fundo & 5 \\
\hline Samambaia & 8 \\
\hline São Sebastião & 18 \\
\hline Taguatinga Centro & 10 \\
\hline Taguatinga & 18 \\
\hline Total: & 80 \\
\hline
\end{tabular}

Fonte: questionários da pesquisa, GEPFAPe: 2016. 


\subsubsection{Entrevista}

Após a aplicação dos questionários foram realizadas entrevistas com os professores sobre aspectos que envolvem o trabalho docente na verticalização do IFB.

As entrevistas seguiram um roteiro estruturado, ou seja, as questões foram estabelecidas previamente com o objetivo de obter diferentes respostas às mesmas perguntas, possibilitando assim que fossem comparadas (GERHARDT; SILVEIRA, Ibidem). As entrevistas seguiram o mesmo roteiro, porém, algumas perguntas específicas foram incluídas levando-se em consideração o perfil dos professores entrevistados, ou seja, considerando se eram professores dedicados exclusivamente à docência ou se exerciam concomitantemente algum cargo sindical ou de gestão no IFB.

Os critérios para escolha dos professores entrevistados foi o de abranger os perfis mais diversos encontrados a partir dos questionários, bem como contemplar diferentes campi do IFB em distintas etapas de implementação.

Dessa maneira, foram entrevistados quatro professores que atuam em cargos de gestão, a saber, Diretor Geral de campus, Diretora de Ensino Pesquisa e Extensão de campus, Coordenador Pedagógico de campus e Coordenador de Curso Superior de campus. Três dos professores entrevistados se dedicam exclusivamente a docência e um professor além da docência, também representa o Sindicato Nacional dos Servidores Federais da Educação Básica, Profissional e Tecnológica (Sinasefe ${ }^{28}$ ) Seção Sindical de Brasília-DF.

Além dos cargos ocupados, os professores representam um perfil variado tanto no que diz respeito às experiências docentes prévias ao IFB, quanto de formação.

O quadro a seguir resume o perfil dos professores selecionados para as entrevistas.

\footnotetext{
${ }^{28}$ Os professores da Carreira EBTT são representados atualmente por dois sindicatos em disputa, o Proifes e o Sinasefe. Em 2015 a $2^{\text {a }}$ Turma do Tribunal Regional do Trabalho da $10^{\text {a }}$ Região negou o recurso do Proifes e manteve a sentença na qual reconhece a representatividade do Sinasefe como entidade responsável pelas negociações com a União Federal quanto à categoria dos Servidores EBTT e não o Proifes.
} 
Quadro 5: Professores selecionados para a aplicação das entrevistas

\begin{tabular}{|c|c|c|c|c|}
\hline $\begin{array}{l}\text { Professor/ } \\
\text { Sigla }\end{array}$ & Cargo & $\begin{array}{l}\text { Formação } \\
\text { inicial }\end{array}$ & $\begin{array}{l}\text { Experiência } \\
\text { docente } \\
\text { prévia ao } \\
\text { IFB }\end{array}$ & $\begin{array}{l}\text { Tempo de } \\
\text { Atuação no } \\
\text { IFB }\end{array}$ \\
\hline Prof-DG & $\begin{array}{l}\text { Professor EBTT e Diretor } \\
\text { Geral de campus. }\end{array}$ & Licenciado & $\begin{array}{l}\text { Educação } \\
\text { Básica }\end{array}$ & 6 anos \\
\hline Prof-DREP & $\begin{array}{l}\text { Professora EBTT e Diretora } \\
\text { de Ensino, Pesquisa e } \\
\text { Extensão de campus. }\end{array}$ & Bacharel & Outro IF & 4 anos \\
\hline $\begin{array}{l}\text { Prof- } \\
\text { CoordPed }\end{array}$ & $\begin{array}{l}\text { Professor EBTT e } \\
\text { Coordenador Pedagógico de } \\
\text { campus. }\end{array}$ & Licenciado & $\begin{array}{l}\text { Educação } \\
\text { Básica }\end{array}$ & $\begin{array}{l}2 \text { anos e } 4 \\
\text { meses }\end{array}$ \\
\hline $\begin{array}{l}\text { Prof- } \\
\text { CoordSup }\end{array}$ & $\begin{array}{l}\text { Professor EBTT e } \\
\text { Coordenador de curso } \\
\text { superior }\end{array}$ & $\begin{array}{l}\text { Bacharel e } \\
\text { Licenciado }\end{array}$ & Não & 3 anos \\
\hline Prof-Sindi & $\begin{array}{l}\text { Professor EBTT } \\
\text { Representante sindical/ } \\
\text { SINASEFE }\end{array}$ & $\begin{array}{l}\text { Bacharel e } \\
\text { Licenciado }\end{array}$ & $\begin{array}{l}\text { Outro IF e } \\
\text { Educação } \\
\text { Básica }\end{array}$ & $\begin{array}{l}1 \text { ano e } 6 \\
\text { meses }\end{array}$ \\
\hline Professora 01 & Professora EBTT & Licenciada & $\begin{array}{l}\text { Educação } \\
\text { Básica }\end{array}$ & 3 anos \\
\hline Professora 02 & Professora EBTT & Bacharel & $\begin{array}{l}\text { Ensino } \\
\text { Superior }\end{array}$ & 7 anos \\
\hline Professora 03 & Professora EBTT & Licenciada & Outro IF & 1 ano \\
\hline
\end{tabular}

Fonte: entrevistas da pesquisa, 2016.

\subsection{O que dizem os professores a partir dos questionários e entrevistas}

A partir das perguntas formuladas e das respostas obtidas nas entrevistas e nos questionários foram categorizadas as seguintes unidades de análise: i) Política de verticalização e integração da educação básica à superior, ii) Elementos do trabalho docente na verticalização e iii) Estruturantes do trabalho docente na verticalização. As unidades de análise são os temas que destacamos ou os "conjuntos de sentidos construídos em torno de uma dada ideia ou assunto - que um sujeito apresenta em determinados contextos sociais, culturais, políticos e etc." (CRUZ, 2012). Esses sentidos estão contidos no objeto elegido para o estudo e são postos em investigação para assim se tornar inteligível no processo de tornar a prática como ponto de partida e de retorno. Tomando como base essas unidades foi possível propor o desvelamento do objeto a partir da análise e interpretação dos sentidos atribuídos pelos sujeitos da 
pesquisa sobre o trabalho docente na verticalização da educação profissional e tecnológica do IFB.

Concebemos esta abordagem na busca pela compreensão do objeto sob a dialética do movimento concreto da realidade estudada e o sentido subjetivo dos professores sobre o seu trabalho. Dessa forma, “[...] a abordagem dialética atua em nível dos significados e das estruturas, entendendo estas últimas como ações humanas objetivadas e, logo, portadoras de significado.” (MINAYO; SANCHES, p. 244, 1993).

Cada uma das unidades de análise foi subdividida em unidades temáticas e essas últimas classificadas como subunidades temáticas. As respostas dos professores aos questionários e entrevistas foram analisadas quanto ao seu conteúdo em uma "[...] abordagem metodológica crítica e epistemologicamente apoiada numa concepção de ciência que reconhece o papel ativo do sujeito na produção do conhecimento." (FRANCO, p. 10, 2012).

Os questionários foram tabulados e as respostas fechadas transformadas em gráficos com seus respectivos percentuais e as respostas abertas foram organizadas conforme as unidades de análise. As entrevistas gravadas foram transcritas e, da mesma forma, as falas dos professores categorizadas, ou seja, com a tarefa de "[...] apreender as mediações sociais constitutivas do sujeito, saindo assim da aparência, do imediato, indo à busca do processo, do não dito, do sentido" (AGUIAR; OZELLA, 2013, p. 303). A intenção assim foi identificar os temas trabalhados na pesquisa relacionados às unidades de análise.

As respostas dos professores às perguntas feitas durante a pesquisa tiveram alguns trechos de destaque negritados, no sentido de produzir inferências, ou seja, a produção de conhecimentos subjacentes à determinada mensagem, e também ancorá-las a um quadro de referenciais teóricos, situação concreta segundo o contexto histórico e social de sua produção (CAMPOS; TURATO, 2009).

A análise dos dados coletados tem início com a caracterização e o perfil dos professores do IFB para que possamos situá-los no contexto da instituição e do trabalho docente. 


\subsubsection{Caracterização e perfil dos professores}

Para caracterizar o perfil dos professores do IFB foram analisados dados referentes à primeira parte do questionário e das entrevistas, considerando faixa etária, experiência docente, sexo, renda, formação e situação funcional.

Os professores que trabalham no IFB têm um perfil etário majoritariamente jovem $^{29}$, onde $34 \%$ dos docentes têm idade entre 21 a 30 anos, $28 \%$ dos professores têm idade entre 31 e 35 anos, os professores com mais de 41 anos de idade somam $20 \%$ e a faixa de 36 a 40 anos representa $18 \%$ do total. Podemos inferir que a recente criação e expansão do IFB e a abertura de novos postos de trabalho por meio de concursos públicos têm atraído professores jovens e recém-formados.

A maioria dos professores entrevistados, $80 \%$, já atuou como docente antes de ingressar no IFB, sendo a maior área de atuação prévia o nível superior, com 34\% dos docentes, seguido de experiência no nível médio com 29\%, ensino fundamental 20\%. A experiência prévia na educação profissional representa $15 \%$ e a educação infantil $6 \%$. Esses dados são indicativos do perfil docente que os editais de concurso do IFB têm atraído, ou seja, predominantemente o professor com perfil universitário e em menor quantidade os professores com experiência na educação profissional.

O tempo de atuação média dos professores no ensino público é de 5 anos e no ensino privado é de 4 anos. $61 \%$ dos professores tem entre 2 e 5 anos de experiência no ensino público e $60 \%$ dos professores tem entre 2 e 5 anos de experiência no ensino privado. De acordo com essas respostas percebemos que o IFB tem atraído majoritariamente professores jovens e em início de carreira.

No IFB há a prevalência das professoras do sexo feminino onde $54 \%$ são mulheres e $46 \%$ homens. Na educação básica, $82 \%$ das professoras são mulheres (GESTRADO, 2010). A feminização do magistério é menor no nível médio, na educação profissional e no nível superior (INEP, 2007), justamente os níveis e modalidades de atuação dos IFs, o que explica percentual considerável de professores do sexo masculino, diferente do que acontece em outras etapas da educação básica, principalmente na educação infantil e os anos iniciais do ensino fundamental. A maior presença de professoras mulheres também é percebida no nível superior nos cursos voltados para a formação de professores (FREIRE, 2011) igualmente outra área de

\footnotetext{
${ }^{29}$ O Estatuto da Juventude, Lei 812.852/2013 considera jovens as pessoas com idade entre 15 e 29 anos de idade.
} 
atuação emergente dos Institutos Federais, o que poderia explicar a predominância de professoras no IFB, tendo em vista a sua atuação prioritária nas licenciaturas oferecidas pelos campi.

A faixa salarial dos professores do IFB está concentrada $62 \%$ com 4 a 10 salários mínimos, atualmente equivalente a $\mathrm{R} \$ 3.520,00$ a $\mathrm{R} \$ 8.800,00$, seguido de $30 \%$ com renda de 10 a 20 salários mínimos, equivalente a $\mathrm{R} \$ 8.800,00$ a $\mathrm{R} \$ 17.600,00$, por fim, $8 \%$ dos professores estão situados na faixa de 2 a 4 salários mínimos, o que equivale a $\mathrm{R} \$ 1.760,00$ a $\mathrm{R} \$ 3.520,00$. O rendimento ${ }^{30}$ médio dos professores da Educação Básica na rede pública no ano de 2014 era de R\$3.173,90. No Distrito Federal os professores da educação básica com formação superior têm o melhor nível de rendimento de toda a federação, mas vivem na cidade que tem um dos maiores custos de vida do país. (ALVES; PINTO, 2011).

Um professor de educação básica de escola pública ${ }^{31}$ no DF com graduação e dedicação exclusiva tem atualmente salário inicial de $\mathrm{R} \$ 5.237,13$. Em comparação, o professor do IFB, nas mesmas condições, com graduação e dedicação exclusiva tem salário inicial de $\mathrm{R} \$ 4.234,77$. Se a comparação for com os professores de nível superior, os professores do EBTT tem a plena equiparação com a Carreira do Magistério Superior e, por força da sua lei de criação, os Institutos Federais são equiparados às universidades federais. Em termos de ganhos entre professores, os docentes do IFB estão na média dos rendimentos, mas não se comparados com outras carreiras federais de nível superior. Dados do IBGE “evidenciam que os professores compõem o grupo de ocupações com menores rendimentos entre as ocupações de nível superior" (ALVES; PINTO, Ibidem). Esse posicionamento é confirmado em outras pesquisas:

O salário inicial de professores no geral tem sido baixo quando comparado a outras profissões que exigem formação superior, e isso tem peso sobre as características de procura por esse trabalho. Entre outros fatores, carreira e salários que estão associados a desprestígio profissional com certeza pesam tanto na procura por esses cursos, como sobre o ingresso e permanência na profissão. (GATTI; BARRETO, p. 240, 2009).

Já a renda familiar mensal dos professores entrevistados concentra a maior parte, $50 \%$, na faixa de 10 a 20 salários mínimos, $31 \%$ na faixa de 4 a 10 salários mínimos,

\footnotetext{
${ }^{30}$ Observatório do PNE http://www.observatoriodopne.org.br/

${ }^{31}$ Tabela salarial Sinpro-DF consultada em 17/8/2016 http://www.sinprodf.org.br/tabelas/
} 
14\% das famílias têm renda acima de 20 salários mínimos, equivalente a $\mathrm{R} \$ 17.600,00$ e 5\% dos professores têm renda familiar de 2 a 4 salários mínimos. Em comparação com a renda no DF, dados de 2013 indicam uma renda média domiciliar mensal de 7 salários mínimos (DISTRITO FEDERAL, 2014). A renda média domiciliar no Distrito Federal é muito diferenciada entre as várias Regiões Administrativas (RA) do DF. Ao analisar cada RA separadamente é revelado o alto nível de desigualdade interna. Enquanto no Plano Piloto a renda domiciliar mensal em 2013 era de 16 salários mínimos, no Lago Sul de 28 e Jardim Botânico 18 salários mínimos. Em RAs como Riacho Fundo era de 4 salários mínimos, São Sebastião 3 e Taguatinga 7. Sob a lógica capitalista, a remuneração é fundamental para qualquer profissão, com os professores não seria diferente (ALVES; PINTO, 2011). O padrão socioeconômico do professor do IFB, que se mostrou bastante variado, depende de seu nível de escolaridade, posicionamento na carreira e região onde reside e trabalha.

A situação funcional dos professores no IFB reflete a forma de ingresso por meio de concurso público enfatizando os professores efetivos, correspondendo a $94 \%$ das respostas nos questionários, $6 \%$ correspondem aos professores temporários e substitutos. Dentre esses professores, $71 \%$ se encontram na situação do regime de trabalho em dedicação exclusiva (DE) e apenas 9\% em regime de 40h. Nenhum professor com carga de $20 \mathrm{~h}$ respondeu ao questionário. Ter professores em regime de dedicação exclusiva segue o modelo das universidades federais para que os docentes possam cumprir o princípio da indissociabilidade entre ensino, pesquisa e extensão. Porém, como já visto anteriormente e nas falas dos professores que irão se seguir, a sobrecarga com o ensino e acúmulo de atividades burocráticas e de gestão tem impedido o desenvolvimento da produção científica e tecnológica. Talvez a DE, nesse modelo de IF, tenha um reflexo muito mais importante na remuneração do que na dedicação ao tripé do ensino, pesquisa e extensão.

A formação dos professores que responderam aos questionários é bastante variada, sendo que $19 \%$ dos professores têm especialização, assim como outros $19 \%$ têm mestrado acadêmico, 17\% realizaram a primeira graduação em uma licenciatura e $15 \%$ tiveram a primeira graduação no bacharelado, $9 \%$ dos professores têm doutorado, apenas 5\% têm a formação em curso técnico de nível médio, assim como 5\% realizaram uma segunda graduação na licenciatura e 5\% fizeram a segunda graduação no bacharelado. $3 \%$ dos professores têm mestrado profissional e 3\% dos professores realizaram a primeira ou segunda graduação como tecnólogos. 
A exigência da Lei de Diretrizes e Bases para atuação na educação básica é que o professor seja licenciado. Nesse quesito apenas $22 \%$ dos professores estariam aptos. A mesma lei indica que para atuar no ensino superior os professores devem pós-graduação e nesse item $56 \%$ dos professores cumprem o requisito. Nas demais situações o IFB apresenta uma situação na qual seus professores atuam na verticalização fora do que é preconizado pela própria lei em termos de formação. Esses professores cumpriram os requisitos dos editais de seleção do IFB, que deveria então oferecer a formação complementar necessária.

Dentre os oito professores que foram entrevistados, a maior parte deles, $75 \%$, ou seja, seis professores têm formação para a docência em cursos de licenciatura. Dois professores, $25 \%$ são considerados bacharéis docentes por exercerem a docência sem uma formação para o magistério, pois contam apenas com um curso em nível superior.

A média de tempo de trabalho no IFB dos professores entrevistados é de três anos, refletindo a situação de uma instituição de ensino recente no Distrito Federal e que tem realizado diversos concursos para preencher as vagas dos professores EBTT que atuam em seus dez campi. Com exceção de um professor, todos os demais sete professores, $87 \%$ têm experiência prévia com a docência e essa experiência é bastante variada, incluindo Educação Básica, Nível Superior e outros IFs.

A partir dos dados coletados traçamos o perfil característico do docente do IFB. Trata-se de uma professora, jovem, com experiência docente prévia no nível superior, está em início de carreira, tem um rendimento entre 4 e 10 salários mínimos e renda familiar mensal na faixa de 10 a 20 salários mínimos. É professora efetiva, em regime de dedicação exclusiva e pós-graduada.

Podemos perceber que o IFB é uma instituição jovem, assim como a maior parte de seus docentes. Por se tratar de uma nova instituição, com menos de dez anos de atuação no DF, a institucionalidade e a identidade do Instituto Federal de Brasília estão em processo de construção e consolidação. Seus docentes têm em grande parte experiência na educação superior, mas se trata de uma instituição educacional que oferta para além de cursos superiores os cursos técnicos de nível médio. Nesse sentido é importante destacar a necessidade de formação dos quadros docentes do IFB para que estes possam atuar de acordo com os diversos níveis e modalidades oferecidos nos seus campi.

A seguir, as unidades de análise são exploradas a partir das falas dos professores, as quais foram organizadas em quadros que constam no Apêndice da pesquisa. 
A primeira unidade de análise trata da política de verticalização e integração da educação básica à superior e busca compreender como os professores se veem no processo de elaboração de políticas educacionais para a educação profissional, bem como o desenvolvimento do seu trabalho na verticalização. Compreendemos a análise dessa política nos Institutos Federais a partir de sua criação no bojo de políticas neoliberais para a educação, cuja lógica, conforme Lima (2007) é voltada para o mercado em uma relação entre a oferta e a procura do serviço educativo e a demanda da sociedade.

4.2.2 Política de verticalização e integração da educação básica à superior

A política educacional que criou os IFs é vista como positiva para sete dos oito professores entrevistados. Os aspectos positivos são referentes ao acesso à educação profissional e superior, bem como o fato do desenvolvimento da política ter levado os IFs para localidades onde antes não havia escolas desse tipo. Ao mesmo tempo, os professores também fazem uma crítica com relação à expansão acelerada dos IFs sem que fosse garantida, por exemplo, a infraestrutura básica de funcionamento que um Instituto Federal exige. A falta de formação dos professores que atuam nesse novo tipo de instituição e a impossibilidade de realizar a contento a integração da educação básica à superior também foram citadas em contraponto à expansão. Essas observações ficam claras nos relatos:

A política segue a proposta expansionista [...]. Então houve a expansão da educação profissional e, ao mesmo tempo, houve um reconhecimento da educação profissional, porque durante um tempo ela ficou às margens, já existia, mas não era vista como tal. Então por esse lado, pelo lado da expansão, eu vejo que houve um reconhecimento. Mas junto com a expansão, a gente tem outros determinantes também e aí, estando na política você começa a elencar aquilo que você vê que, em função da expansão foi revelado. Mas eu vejo com bons olhos, de toda forma eu vejo com bons olhos. (Prof. 01).

Como querer fazer um bolo, mas não ter esses ingredientes que eu chamo de formação de professor. Então, os professores que começaram a compor essa ideia, tiveram que aprender no meio do caminho. Essa é a minha visão, uma boa intenção, mas, é um tanto quanto emocionante, aprender fazendo e isso tem os seus problemas, parece. (Prof. CoordPed). 
A fala dos professores demonstra as contradições de uma política expansionista da educação profissional porque promoveu o acesso ao ensino básico e superior sem necessariamente oferecer as condições de trabalho adequadas para o seu funcionamento. Essa expansão, por meio da ifetização dos CEFETs e outras de escolas federais aparenta ser uma solução para as populações de baixa renda e baixa escolaridade, mas "na essência não deixam em hipótese alguma de atender aos organismos internacionais como o FMI e o BM, e consequentemente o grande capital." (SANTOS; JIMENEZ; SEGUNDO, p. 299, 2013). A expansão dos cursos superiores por meio dos IFs aumentou a oferta dos cursos de graduação tecnológica, "um curso fragmentado, aligeirado e diametralmente oposto aos anseios de uma educação verdadeiramente omnilateral" (Ibidem, p. 295).

Ao ofertar cursos tecnológicos, considerados na LDB como cursos superiores, mas também chamados de ensino superior não universitário ${ }^{32}$ (ESNU) questiona-se qual o projeto educativo se propõe para a classe trabalhadora que se sente agraciada por ter a oportunidade de alcançar um nível de ensino que a rigor não é universitário e descaracteriza a pesquisa e a extensão.

No caso das licenciaturas nos Institutos Federais, essa oferta vem para suprir especialmente a falta de professores nas áreas de ciências e matemática na educação básica e para oferecer formação pedagógica para professores não licenciados. Conforme Lima (2014) trata-se de uma condição inédita em instituições públicas de educação profissional e tecnológica a reserva de vagas para a oferta de cursos de licenciaturas. Além da falta de identidade sobre a institucionalidade dos IFs, esse quadro ainda pode comprometer a qualidade do ensino por suas implicações no trabalho dos docentes que atuarão nos cursos de formação de professores.

Concordamos com Lima ao abordar a questão dos docentes dos IFs que atuam na formação de futuros professores de maneira polivalente, ou seja, não há um “[...] corpo docente especializado para as licenciaturas, que por sua vez acarreta na necessidade de uma discussão do professor polivalente para diferentes níveis de ensino [...]" (Idem, p. 236). E essa condição de oferta de cursos superiores de licenciatura, bacharelado e tecnólogo, acontece tendo um quadro de professores que não necessariamente tem a qualificação para atuar no nível superior.

\footnotetext{
${ }^{32}$ Termo utilizado pelo Instituto Internacional para a Educação Superior na América Latina e no Caribe (IESALC), membro da Organização das Nações Unidas para a Educação, Ciência e Cultura (UNESCO).
} 
No processo de desenvolvimento de políticas educacionais para a educação profissional os professores foram perguntados como se viam e em primeiro lugar, $27 \%$ dos professores se consideram receptores passivos da política; seguidos de $19 \%$ que se veem como avaliadores ativos da política propondo seu aperfeiçoamento em nível institucional; $11 \%$ se veem como agentes indutores na formação da agenda política (apresentando a necessidade de ação do Estado); 10\% se consideram participantes ativos nas decisões de implementação da política; 9\% agentes sem autonomia para executar a política; $8 \%$ como consultores de temáticas relacionadas às políticas a serem implementadas; $6 \%$ indutores institucionais da implementação da política; 5\% avaliadores ativos da política propondo seu aperfeiçoamento em nível regional e 5\% avaliadores ativos da política propondo seu aperfeiçoamento em nível nacional.

A maioria dos docentes, $64 \%$, se percebe de maneira positiva, influenciando nas políticas educacionais para a educação profissional e 34\% se veem sem autonomia frente às decisões, em um processo de desqualificação do trabalhador e de separação entre concepção e execução no trabalho (APPLE, 1995). Trata-se de uma situação paradoxal na qual os professores se reconhecem influenciando a política, porém de maneira mais local do que em nível nacional, o que nos remete à nova racionalidade de gestão das instituições educacionais, reduzidas a "aspectos técnicos, mensuráveis, que moldam o trabalho docente segundo expectativas externas à comunidade escolar" (SHIROMA; SANTOS, 2014, p. 14), levando, segundo os autores, a uma fragmentação política dos sujeitos, o que torna suas ações restritas às questões do cotidiano escolar.

Ao serem indagados se tinham conhecimento prévio sobre a política de verticalização e integração dos IFs, seis dos docentes entrevistados informaram que não e apenas dois afirmaram que sim. Mesmo constando no edital de concurso para contratação de professores EBTT, nem todos entenderam de fato como se daria essa atuação verticalizada no IFB. Para a maioria dos docentes, a compreensão sobre o trabalho verticalizado somente aconteceu em serviço, conforme podemos perceber nas falas:

$\mathrm{Na}$ verdade, a ideia que eu tinha do IF quando eu entrei, era ainda uma ideia de escolão, que era oriundo dos antigos CEFETs e por consequência também eram frutos da Escola Técnica Federal e a Escola Técnica Federal que eu me lembro bem, quando eu era adolescente, era uma escola profissionalizante e só. Não tinha uma perspectiva de várias modalidades no mesmo espaço, então as diversas modalidades que existem no IF eu vejo até com bons olhos, agora como é esquematizado isso que também é um 
problema, né? Porque a gente tem que se desdobrar em várias modalidades, muitas vezes não tem uma formação. (Prof-Sindi).

Sabia, talvez por uma particularidade. Eu fui aluno de CEFET [...] Então, eu já tinha noção do que era a Rede. Não sei se vai te ajudar na pergunta, mas eu percebo, enquanto gestor, que muitos professores não tinham essa noção, quando entram aqui, da verticalização. Talvez uma noção, às vezes um ouvir falar, mas não sabia como, não sabe como vai se dar na prática. A gente sabe que acontece, ou criam resistências na hora de vir para prática. (Prof-DG).

A maioria dos docentes desconhecia quais seriam as implicações da verticalização sobre o seu trabalho e indicaram em suas falas que foram aprendendo enquanto trabalhavam. Ao contrário, nos questionários, $66 \%$ dos professores afirmam que conheciam a política de verticalização dos IFs e $34 \%$ afirmaram que não conheciam. Mesmo assim, observa-se um número significativo de docentes que não tinha clareza da verticalização, nem mesmo da relação entre esse princípio de gestão e a política de expansão da qual viriam a fazer parte.

O IFB, por ser uma instituição recente em Brasília, com menos de uma década de atuação, tem atraído professores para seus quadros por meio dos diversos concursos públicos, porém, a instituição não oferece um programa de formação para os recémingressantes no sentido de conhecer a estrutura do IFB, cada campus o faz de maneira distinta.

Assim, a relação do professor com a polivalência por nível de ensino e o trabalho verticalizado vai depender da fase de implantação de seu campus, pois há aqueles que oferecem todos os níveis e modalidades exigidos em lei e outros que ainda estão em processo de discussão e análise da oferta de cursos como o EMI, Proeja e cursos superiores. Porém, independente do campus de atuação, todos os docentes estão sujeitos à política de verticalização e integração educacional, na busca pela otimização dos recursos.

Temos assim a visão dos professores do IFB no processo de elaboração das políticas educacionais para a educação profissional e as influências no desenvolvimento do seu trabalho na verticalização. Essa política é vista como positiva, desconhecida e contraditória, pois expandiu o acesso à educação profissional, mas deixando a desejar em termos de infraestrutura adequada para a realização do trabalho bem como as falhas institucionais na formação do corpo docente. 
Essa questão nos leva à próxima unidade de análise que trata sobre os elementos do trabalho docente na verticalização. Oliveira (2004) afirma que o "contexto de nova regulação das políticas educacionais tem sido pouco estudado no que se refere aos seus reflexos sobre o trabalho docente." (p. 1130), dessa forma, abordamos o tema da formação docente para uma atuação verticalizada e integrada, as relações entre professores e o sindicato, as atividades de gestão, ensino, pesquisa e extensão, a divisão da carga horária docente diante das características da verticalização e as condições de trabalho na perspectiva dos docentes do IFB.

\subsubsection{Elementos do trabalho docente na verticalização}

Nesta unidade de análise partimos do par dialético trabalho-formação, uma vez que entendemos a formação docente a partir da natureza do seu trabalho (LIMONTA; CURADO SILVA; 2013). Os pares dialéticos expressam uma trama de relações contraditórias e conflitantes entre si (FRIGOTTO, 2010) nas quais podemos observar o seu movimento. Os professores foram questionados a respeito da formação que eles sentem ser necessária no exercício da docência nesse contexto de verticalização. Nas entrevistas, as formações continuadas voltadas para níveis e modalidades específicas tiveram a maior frequência de respostas, seguidas da necessidade de o IFB oferecer formação para os professores atuarem na verticalização. A atualização na própria área de conhecimento e a não necessidade de formação específica para atuar no nível superior também surgiram nos comentários dos docentes como podemos ver a seguir:

O professor, ele tem que estar sempre sabendo o que tá acontecendo na área dele. Não tem jeito de ele fazer uma faculdade, fazer uma pós-graduação e ficar por isso mesmo, entrar na sala de aula e fechar a porta e agora eu sei tudo. Não dá, não dá. (Prof. 02).

Acho que aí vai depender de onde eu vou estar. Se eu estiver no médio, é de educação de ensino médio, dependendo da disciplina, porque, eu imagino que se eu fosse das disciplinas mais específicas, então talvez não, mas, por exemplo, o curso técnico, educação de jovens e adultos, eu preciso ter os pressupostos mínimos de educação de jovens e adultos. É ensino superior, docência no ensino superior, é inadmissível você não ter docência no ensino superior e eu vejo isso agora porque acabei de fazer a disciplina, a gente faz muito, muitas coisas por indução, porque eu tive uma formação, eu acredito que, se eu não tenho base, eu vou recorrer à formação que eu tive, que eu considero que foi boa porque, pelo menos teve um bom resultado. Mas é preciso o instituto ter uma 
política diferenciada pra cada área, se ele se propõe a fazer a verticalização tem que ter a formação específica pra cada caminho, mas que, por exemplo, no início, seria bom que o professor chegasse aqui e já tivesse como ambientação, aqueles cursos de formação que a EAPE faz, por exemplo, no GDF. O que é a verticalização? Onde você pode atuar? Quais são suas possibilidades? A partir daí você cria essa identidade formativa. Que o IF poderia ter essa responsabilidade inicial de mostrar o que é a verticalização, um curso sobre o que é a verticalização, de repente. (Prof. 01).

Nos questionários, a maior prevalência de respostas sobre a formação que os professores sentem ser necessária no exercício da docência predominou a licenciatura e a graduação seguido de pós-graduação stricto sensu e lato sensu. Diversos professores afirmaram ser necessária somente a graduação, visto que essa é a única exigência do concurso para o IFB. Houve menor prevalência de respostas para a necessidade de formação pedagógica e conhecimentos para lidar com modalidades como a EJA, o ensino técnico e a educação especial, por exemplo. A atuação verticalizada como um conteúdo formativo na relação trabalho-formação aparece na fala do professor do Campus São Sebastião “O ideal seria formação e experiência na área de atuação, mas até para reconhecer qual área o docente vai atuar é difícil, pois ele pode ir desde os cursos FIC até a pós-graduação.” (Prof. 02 CSSB).

Nas demais respostas os professores ressaltaram a necessidade de uma formação acadêmica combinada com a experiência profissional, uma vez que também atuam em cursos técnicos. Historicamente, a docência tem sido conceituada como uma atividade de menor importância, na qual o domínio do conteúdo tem sido julgado a parte mais importante do trabalho, ou seja, bastaria isso para que um professor pudesse ser considerado apto a dar aulas, quer dizer que "quem domina um conteúdo está pronto a ensiná-lo" (GONTIJO, p. 194, 2014), quando a docência exige, no entanto, formação específica para o ensino.

Saviani (2009) acrescenta ainda que os professores universitários têm certa depreciação sobre os aspectos pedagógicos do seu trabalho. Podemos perceber tanto na literatura quanto na fala dos professores do IFB que o conteúdo escolar e os saberes especializados da área técnica têm sido os principais referenciais para a atuação docente, quase que descartando as especificidades da Didática enquanto área do conhecimento, bem como as singularidades do ensino e da aprendizagem de cada público específico, nível e modalidade. 
Os professores do IFB, por estarem na fronteira entre ser professor da educação básica e do ensino superior parecem reproduzir a institucionalidade de uma universidade em uma instituição que não é uma universidade, mas é híbrida e verticalizada. Percebemos assim o reconhecimento da área de especialidade do docente como quase que essencial e a área da didática com uma leve aproximação de interesse para o trabalho. O conhecimento sobre os níveis e modalidades demandados pelo efetivo exercício seriam aprendidos no fazer docente, ou seja, não há uma busca pela crítica ou reflexão coletiva sobre a educação profissional como uma modalidade que atende a diferentes públicos. Parece haver mais uma visão fragmentada a partir da demanda específica do trabalho no contexto da verticalização, inclusive alguns professores demonstram o interessem em atuar em apenas um nível como a situação ideal de trabalho.

O professor representante do sindicato indicou que com relação à formação dos docentes, o sindicato não teria a proposta de uma formação pedagógica em si para a atuação no magistério e na verticalização, mas sim voltada para questões de política e direitos trabalhistas como ficou explícito na fala:

A gente está tentando seduzi-los no sentido da importância de participação no sindicato, com eventos que possam fomentar a discussão política sob propostas que atacam direitos já conquistados, sobretudo nesse ambiente de golpe, que nós do sindicato acreditamos que vivemos uma situação de exceção e que se aprofunda cada vez mais por interesses de grandes empresários, assim, de multinacionais, interesses de soberania nacional, sobre o petróleo, o interesse para a terceirização do processo de educação, a privatização da saúde... Então, tudo aquilo que foi que precisa ainda ser consolidado por uma Constituição cidadã, a de 88 que não foi, nunca foi. Precisa ser fomentado, mas, o excesso de trabalho do docente e do técnico, né? Tendo que exercer funções que não são necessariamente da docência em si, mas coisas extremamente burocráticas, que dividem, inclusive, a categoria, porque existe uma desunião muito grande entre nós servidores, não é?

[...] E essa verticalização ainda é um terreno ainda pantanoso, meio penumbra pra muita gente que não tem noção do que significa, do que se trata de fato essa verticalização? O que seria mais interessante nessa educação? Que tipo de educação nós queremos? Eu mesmo tenho as minhas dúvidas. Há uma discussão pouco frutífera sobre esse projeto, não há o engajamento. (Prof. Sindi).

$\mathrm{Na}$ fala do professor e representante sindical ficam claros aspectos do isolamento, da sobrecarga dos docentes e a dificuldade para realização da formação. 
Os professores falaram sobre as ações desenvolvidas pelo sindicato e a sua contribuição para a formação e profissionalização no IFB e $92 \%$ afirmaram que não há contribuição, contra apenas $8 \%$ que responderam positivamente. Os professores destacaram em suas justificativas como o sindicato tem atuado em sua formação, tal como “A cobrança por mestrados profissionais, por exemplo, é uma ação" (Prof. 07 CSAM). Mas o que chamou a atenção foram as falas que tratam da individualização na busca por formação "Não é essa a finalidade do sindicato" (Prof. 03 CSSB) e "Sindicato ausente. Ainda mais a formação docente depende única e exclusivamente do próprio docente" (Prof. 04 CTGT). Nas justificativas para as respostas, a maior frequência de explicações dos professores indica que eles não conhecem as ações do sindicato ou não têm opinião sobre esse assunto. A segunda maior frequência de respostas apontou a insatisfação dos docentes com as ações do sindicato.

Os professores pouco percebem a atuação do sindicato, ora por puro desconhecimento e por achar que sua função não se refere à formação, contraditoriamente, indica-se uma aproximação quando este mesmo sindicato busca por parcerias para mestrados profissionais. Nóvoa (1999) acredita que o sindicalismo docente está se revitalizando, mas que esse fato "não compensa a inexistência de uma colegialidade que não se esgota nos modelos sindicais tradicionais.” (p.7). O autor afirma que há uma fragilidade nesse movimento associativo entre professores, os quais oscilam entre o "individualismo" nas suas ações pedagógicas e os modelos sindicais típicos de "funcionários do Estado". Essas são consideradas

formas obsoletas de encarar a profissão. O empobrecimento das práticas associativas tem consequências muito negativas para a profissão docente. É urgente, por isso, descobrir novos sentidos para a ideia de coletivo profissional. É preciso inscrever rotinas de funcionamento, modos de decisão e práticas pedagógicas que apelem à co-responsabilização e à partilha entre colegas. É fundamental encontrar espaços de debate, de planificação e de análise, que acentuem a troca e a colaboração entre os professores. (Idem, p.8)

Sobre a relação com o sindicato, $76 \%$ dos professores informaram não ser sindicalizados contra $24 \%$ de sindicalizados. Para justificar essas escolhas os professores sindicalizados fizeram a maior parte dos comentários, enfatizando que a filiação fortalece o sindicato em prol da categoria. A segunda maior frequência de justificativas foi entre aqueles professores não sindicalizados que afirmam não perceber a atuação do sindicato no IFB. A terceira maior frequência de respostas diz respeito aos 
professores que consideram o sindicato uma extensão político partidária. Os demais comentários dizem respeito ao fato dos professores não se sentirem representados pelo sindicato e por não terem visto vantagem individual ou necessidade de se sindicalizar. Destacamos algumas falas como a do professor "Embora eu tenha muitas críticas à ação sindical e à atuação do meu sindicato, acredito na importância de estar vinculada a uma estrutura de representação de minha categoria." (Prof. 16 CSSB) e "Não sou sindicalizada ainda porque não tive até o momento necessidade de sê-lo." (Prof. 08 CTGC). Ao ser questionado sobre o baixo percentual de professores sindicalizados no IFB, o professor e representante sindical relatou:

Eu acredito que a crise da representatividade, ela já tem alguns anos, talvez décadas e que a cidadania através do tem criado no sistema atual capitalista uma mentalidade extremamente individualista. Os proventos, eles são muitas vezes melhorados pela luta sindical, mas o interesse pela defesa desses, dessas garantias, desses direitos, dessas conquistas, não tem uma clareza, provavelmente porque muitos servidores não têm uma formação política necessária para entender o complexo sistema em que nós vivemos. Então, eu penso que a pouca adesão, o pouco interesse por política tem a ver também um pouco com a desilusão de sonhos, das utopias que elas foram consumadas pelo poder de compra, ou melhor, a possibilidade de crédito. Eu vejo muito isso, que as pessoas tendo crédito elas se resolvem e resolvem esses problemas de felicidade consumindo. (Prof. Sindi).

O sindicalismo docente no Brasil, conforme Dal Rosso (2015) tem atuação de bastante destaque, tanto em quantidade de sindicatos, quanto em número de filiados. A fragmentação sindical no setor da educação é uma realidade, pois há várias divisões internas como a existência dos sindicatos para os docentes da educação básica, para os docentes do nível superior, para os docentes do ensino profissional e ainda a divisão entre docentes e técnicos, mesmo que todos sejam considerados trabalhadores da educação.

De acordo com Rêses (2015), os sindicatos, como elementos da superestrutura, articulam interesses de classe e são, portanto, estruturas político-ideológicas portadoras de determinadas concepções políticas. Ao falar em organização sindical, filiação e identificação é preciso também falar em profissão, porque “[...] sindicato e profissão se vinculam mutuamente, pois o sindicato agrupa pessoas de uma profissão por meio de uma organização interna para assegurar a defesa e a representação da respectiva profissão." (Ibidem, p. 22). Nas respostas dos professores percebemos que os docentes 
não se sentem como parte de um coletivo, nem compreendem o sindicato como espaço de organização e luta comum.

Diante das colocações dos docentes constatamos uma atuação mais individualizada seja em suas próprias ações pedagógicas ou de qualificação, nas quais os professores percebem a formação como uma iniciativa individual e não, conforme Curado Silva e Limonta (2014) como um direito do professor que "possibilita a construção de sua identidade e viabiliza sua profissionalização, uma vez que compõem, junto com a carreira, a jornada de trabalho e a remuneração, elementos indispensáveis de valorização profissional e constituição do profissionalismo" (p. 12). Depreendemos ainda que o docente para atuar no Instituto Federal de Brasília deve ser polivalente, flexível e adaptável às exigências da instituição. Este professor, licenciado ou não, pósgraduado ou não precisa dar conta das especificidades do ensino médio integrado e subsequente, da educação de jovens e adultos, da educação especial inclusiva e do ensino superior, independente da sua formação, uma vez que a exigência para ingressar na instituição é somente a graduação.

Apenas dois dos professores entrevistados indicaram ser responsabilidade da instituição oferecer formação mínima para que os docentes possam atuar na verticalização, o que nos leva a questionar de quem é a responsabilidade para os demais docentes. Essa fragiliza o par dialético trabalho-formação ao ponto do professor não reconhecer a responsabilidade institucional na sua formação. Muitos docentes creem ser essa uma responsabilidade individual, a busca pela sua própria qualificação para se adaptar a um ambiente escolar totalmente novo e verticalizado.

Sobre a formação continuada, os professores afirmaram em sua maioria, $63 \%$ que o IFB estimula e facilita a sua formação continuada, ao contrário de $37 \%$ que afirmaram que o IFB não estimula nem facilita sua formação continuada. Dentre os docentes que já participaram de algum tipo de formação continuada $73 \%$ afirmaram ter sido útil para sua atuação como docente, enquanto $27 \%$ afirmaram não ter sido útil. Esses dados indicam a vontade e a necessidade que os professores têm de se manterem atualizados, seja em suas próprias áreas de formação, seja em questões pedagógicas relacionadas à docência nos muitos níveis e modalidades oferecidos pelo IFB.

A disponibilidade para a realização de cursos, planejamento do trabalho pedagógico, bem como atividades de pesquisa e extensão podem ser influenciados pela carga horária de trabalho. Sendo um dos elementos que compõem o trabalho docente, os professores que atuam na gestão falaram a respeito da questão da divisão da carga 
horária docente diante das características da verticalização. O Diretor Geral afirma que cada campus realiza a divisão da carga horária docente de maneira autônoma:

É, no nosso caso, eu vejo uma coisa positiva, porque isso não está institucionalizado, os campi não são obrigados a fazer assim e aí eu vejo que tem outras propostas relevantes de carga horária, que impactam diretamente na pergunta aí e nas dificuldades geradas pela verticalização que eu vejo como positivas.

[...] E tenta também reduzir o número de disciplinas, quando possível. Isso acontece mais quando você tem mais de um ou mais de dois professores de uma mesma área e a gente acaba caindo na armadilha dos casos que a gente só tem um è̀s vezes até com dois professores fica difícil, você pode ter um universo, uma quantidade grande de disciplinas que tem que caber em um sujeito só ou em dois sujeitos, que acaba voltando para o problema da pergunta anterior, o que onera muito a capacidade do docente. (Prof. DG).

A fala da Diretora de Ensino, Pesquisa e Extensão se refere à carga horária, bem como a outros elementos que impactam nos processos de verticalização:

A gente tem dificuldade sim, não é fácil, mas assim, dentro dos colegiados as pessoas estão se entendendo, não sobrou muito pra gestão, tenho notícias de outros campi a gestão tem que interferir muito, mas aqui geralmente o grupo consegue dividir, agora se o grupo faz por área de conhecimento ou não, eu não sei. Apesar de ter, de ser importante a gente com a questão da avaliação dos cursos superiores, privilegia quem tem mestrado e doutorado no curso superior, mas daí já não sei se é uma questão do conteúdo ou da habilidade com a turma ou qualquer coisa assim, acaba que a gente perde o semestre por conta da avaliação. (Prof. Drep).

Temos uma situação na qual a lógica da integração se esvazia, uma vez que um mesmo espaço abriga diferentes níveis e modalidades, mas em razão das políticas de avaliação educacional a concentração da carga horária docente pode ser direcionada conforme sua formação, de maneira que os cursos superiores sejam bem avaliados. Essa situação poderia gerar atritos internos entre os docentes, bem como "castas" dentre aqueles que poderiam ou não lecionar no nível superior e aqueles que deveriam ter sua carga horária de ensino mais direcionada para a educação básica.

Os professores relataram sobre como veem a questão das condições de trabalho diante dessas características da verticalização em seus respectivos campi, e foram questionados se essas condições interferiam no seu trabalho como docentes. Para dois 
dos professores entrevistados o IFB oferece boas condições de trabalho, principalmente na infraestrutura de salas de aula e equipamentos didáticos, inclusive com tempo suficiente para o planejamento das aulas. Para a maior parte dos entrevistados, no entanto, as condições de trabalho na verticalização dos Institutos Federais fazem com que o professor divida sua carga horária em sala de aula em várias áreas de atuação, pois há uma quantidade excessiva de componentes curriculares diferentes a serem ensinados.

Essa não é a realidade de todos os docentes, há uma disparidade enquanto alguns lecionam dois componentes diferentes, há aqueles que lecionam até seis componentes em cursos distintos e se sobrecarregam, como podemos perceber nas falas de um professor, um gestor e o representante sindical:

Olha, é complicado porque é você dividir a suas horas pra várias áreas. Pra você fazer, por exemplo, uma ementa, ou todo um estudo em cima de um curso de FIC, por exemplo, é claro que você não vai entrar muito na informação porque é um curso de curta duração. Então, você tem um tempo menor pra fazer. Quando você trabalha, eu acho que assim como é gradativo, gradativo também no conhecimento, o FIC você consegue fechar ele redondinho mais rápido. O técnico já te demanda um pouco mais de tempo e o superior você precisa focar em algumas especificidades, você não pode abrir igual ao técnico, ele não pode ensinar modelagem para o técnico igual ensina para o superior. Mas ao mesmo tempo, eu vou ser cobrada por esse aluno que tá ali no superior e que não passou pelo técnico "porque que você ensinou determinada coisa lá no técnico e não no superior?" É difícil explicar pra ela que eu não tenho condições de ensinar pra ela uma coisa do métier $^{33}$ mesmo, do fazer a coisa, sendo que ela tá tem que tá preocupada em projeto. Que é outra linha da área do corte. Então é difícil, é bem complicado. Demanda muito tempo. (Prof. 03).

Que para mim, a verticalização não é um problema em si, o problema são as condições que a gente tem para fazer essa sonhada verticalização de forma sonhada, da forma que a gente sonhou e gera mil problemas pra mim enquanto gestor.

[...] Bom, quando você vê e quando o docente vem até o gestor e fala "pô, eu não estou aguentando, seis disciplinas". Como é que você quer que eu faça? Aí eu olho para os meus recursos humanos, eu tenho um teto, de setenta (professores). E, eu gero outro problema, por exemplo, eu vou baixar de seis meu exemplo aqui para quatro, "Você está, você está com quatro componentes, mas você está com oito aulas e para equalizar a conta - deve ir a dezoito -, não tem como eu chamar outro professor, porque se eu chamar outro professor da sua área, você vai ficar com quatro aulas enquanto os outros professores vão ficar com dezesseis, dezoito. Isso gera sim um problema para a

\footnotetext{
${ }^{33}$ Francês: área de trabalho, de atuação; ofício, profissão, ocupação.
} 
gestão e inclusive um problema de motivação. E já com caso concreto. Esse caso concreto que eu vou citar tange a verticalização, mas, já tive relatos de uma colega professora de um campus, que foi contratada na área de informática e ela tinha doutorado e o campus para o qual ela foi só tinha, na época, demanda de informática para curso de formação inicial e continuada e um dia teria no nível médio, técnico integrado de nível médio. E ela se sentiu desconfortável por ter titulação de doutorado, não sei, entrou uma questão de vaidade, e eu acho que a atitude dela pode até ter sido correta, porque ela não se sentia bem dando aula em curso elementar e pediu exoneração, talvez o que mais se encaixasse nas expectativas dela fosse realmente uma universidade ou um campus que tinha curso superior na área dela, curso de informática, mas como ela não tinha gerência sobre isso, ela se exonerou. (Prof. DG).

Estresse, pessoas estafadas, sobrecarga muito grande de turmas, sem tempo para pensar o tripé que foi apregoado muito na universidade que também não foi praticado com excelência que é o ensino, pesquisa e extensão. Nessa instituição eu só consigo praticar o ensino e não tenho condições de tempo mesmo para participar de qualquer projeto de pesquisa e extensão, por conta de comissões, de reuniões, de resoluções e de tentar ainda... Porque o IFB, sobretudo o IFB que é uma instituição que foi criada muito recentemente, diferente de outras que tem um histórico centenário inclusive, ainda está em fase de formação. As pessoas não sabem lidar com isso. Muita gente trabalha na educação sem ter licenciatura, por exemplo, ou técnicos em assuntos educacionais, mas que não tem uma formação mais pedagógica. Então eu vejo que é um dilema, sobretudo para quem continua e não sai do IFB, porque o IFB muitas vezes é uma passagem, tem gente que entra e sai. (Prof. Sindi).

Nesse movimento, os professores indicam que em seu trabalho cada um vai priorizar uma área, seja o docente que atua exclusivamente no ensino, pesquisa e extensão, seja o professor que assume cargos de gestão e precisa tomar decisões administrativas. $\mathrm{O}$ estresse e a sobrecarga fazem com que o foco seja no ensino verticalizado, e que não seja possível a todos os docentes realizem o tripé que seria complementado com a pesquisa e a extensão.

Considerando que o trabalho docente no IFB não se resume ao ensino, $71 \%$ dos docentes responderam que realizam ou já realizaram pesquisa, contra $29 \%$ que não realizam atividades dessa natureza. Na extensão a situação é semelhante sendo que a maioria dos professores, $78 \%$ realiza ou já realizou atividades de extensão contra $22 \%$ que não realizam. Com relação à divulgação dos resultados das pesquisas e projetos de extensão, 59\% dos professores não publicam artigos contra $41 \%$ que afirmaram publicar. Um dos docentes indica que o problema não é a verticalização em si, mas a 
falta de instrumental para realizá-la. Esse comentário nos leva à próxima questão sobre o trabalho docente.

Ao serem solicitados para classificarem o grau de satisfação com o trabalho docente no IFB os professores foram enfáticos em responder com $84 \%$ de satisfação nas respostas que englobam os quesitos bom e muito bom. O quesito médio teve $14 \%$ das respostas e $2 \%$ consideraram como ruim ou muito ruim. Alguns dos professores fizeram comentários demonstrando sua satisfação, tais como "Ambiente favorável para desenvolver meu trabalho" (Prof. 05 CCEI) e "trabalho com o que gosto e os estudantes são tranquilos em relação às outras escolas." (Prof.02 CPLA). No entanto, apesar do alto percentual de satisfação a maior prevalência de comentários foi em relação às melhorias que poderia haver para que o trabalho pudesse ser mais bem desempenhado. Alguns exemplos "Gosto muito da docência, mas as atividades de gestão e as comissões não nos dão tempo de dedicar mais" (Prof. 02 CRFU), "sinto-me cansada." (Prof. 02 CSAM), "Poderia ser ainda melhor com a estrutura física adequada." (Prof. 06 CTGC), $\mathrm{e}$

\begin{abstract}
Ainda não consigo fazer pesquisas. Efetivamente o campus, como um todo, só valoriza os profissionais com elevada carga horária, desmerecendo, muitas vezes as outras atividades desenvolvidas pelos servidores, tais como pesquisa, orientação de alunos, produções científicas, dentre outras. (Prof. 06 CSAM).
\end{abstract}

Esses relatos dos professores indicando ao mesmo tempo satisfação e insatisfação com o trabalho revelam vivências de prazer e sofrimento na docência. Para alguns professores, o não reconhecimento do sofrimento com o trabalho é uma estratégia defensiva

Por outro lado, Dejours (2001) comenta que as estratégias defensivas podem também funcionar como uma armadilha, que insensibiliza contra aquilo que faz sofrer. Isso porque, na concepção de Dejours (1992), apesar dos trabalhadores vivenciarem o sofrimento, eles não o reconhecem, pois a função primária de defesa é aliviar o sofrimento, mas sem conhecer a forma e o conteúdo desse sofrimento, é difícil lutar eficazmente contra ele. (MENDES et. alii, op. cit. p.5)

Vilela, Garcia e Vieira (2013) afirmam que, no caso dos professores das universidades públicas, a partir das mudanças recentes da economia de mercado global foram incorporadas novas e contínuas exigências à atividade docente e o "o impacto dessas mudanças se faz sentir pela intensificação do trabalho do professor, uma vez que 
essas instituições assumem os mesmos pressupostos ditados pela economia de mercado." (Idem, p. 518). A educação passa a ser gerida por contratos de gestão, avaliada por índices de produtividade e calculada para ser flexível.

Ao serem perguntados sobre as vantagens do trabalho no IFB os professores consideram a autonomia, a realização pessoal, o plano de carreira e a flexibilidade da carga horária como as mais importantes. As principais desvantagens citadas foram o desgaste emocional, o desgaste físico, a competição entre os pares e o salário. Com relação à remuneração, vimos no perfil docente a disparidade entre os salários e as condições de vida em cada uma das regiões do Distrito Federal. Sem a formação adequada os professores não avançam no plano de carreira e se encontram em desvantagem financeira com seus pares nas Universidades Federais e inclusive em comparação com os professores de educação básica local.

Vale ressaltar, no entanto, que houve mais respostas sobre as vantagens do que sobre as desvantagens, indicando a prevalência das vivências de prazer no trabalho. As vivências de sofrimento foram menos prevalentes, mas não desprezíveis e mostram um cenário de desgaste focalizado. As ambiguidades do contexto de trabalho dos professores do IFB fazem com que parte deles vivenciem o prazer e outros o sofrimento da docência mediante a intensificação, a falta de condições de trabalho, a exigência de produtividade e a conciliação com atividades burocráticas e de gestão.

Quando os professores foram perguntados sobre as questões de infraestrutura dos seus respectivos campi, a começar pela adequação das bibliotecas para atender a demanda de todos os cursos oferecidos os docentes se dividiram, sendo que $50 \%$ acreditam que a biblioteca dos seus campi atendem parcialmente ou totalmente as necessidades dos cursos e 50\% acreditam que não atendem integralmente ou em parte às necessidades de todos os cursos oferecidos. O espaço físico dos campi foi considerado adequado para receber os cursos por $65 \%$ dos docentes, enquanto $35 \%$ acreditam que não há adequação para receber todos os cursos. Sobre o local adequado para que os professores realizem atividades de planejamento didático $51 \%$ dos professores afirmam que não há local adequado, contra $49 \%$ que considera o local de planejamento oferecido pelo seu campus é satisfatório.

$\mathrm{Na}$ avaliação da infraestrutura há uma divisão bastante marcada entre os docentes, revelando mais uma vez a diferença entre os diversos campi que compõem o IFB e a estrutura física que estes oferecem para a realização do trabalho docente verticalizado na oferta de múltiplos cursos. Já na fala dos professores percebemos a 
ambiguidade do fato de que os docentes gostam do trabalho, querem desenvolver suas atividades e contribuir para a formação dos estudantes, mas alguns se sentem sobrecarregados, a infraestrutura nos campi não considerada adequada em algumas situações e as atividades de pesquisa e extensão ficam em segundo plano em detrimento do ensino. Ou seja, parece haver no geral a concordância dos professores com a organização curricular da verticalização, mas não como a materialidade do trabalho está constituída nesse princípio.

As respostas dos professores sobre a situação da divisão da carga horária é ainda mais dispare. Os quatro maiores percentuais que indicam a quantidade de horas em sala de aula mostram que $16 \%$ dos professores têm uma carga horária de menos de $8 \mathrm{~h}, 15 \%$ tem $8 \mathrm{~h}, 14 \%$ atuam $12 \mathrm{~h}$ e $13 \%$ tem $10 \mathrm{~h}$ em sala de aula. Enquanto isso, $42 \%$ dos demais professores têm cargas horárias em sala de aula que variam entre 14h e 20h. Esses números refletem duas situações: mais uma discrepância entre os campi que compõem o IFB, pelo fato de alguns terem a verticalização dos cursos completa e outros ainda estarem em fase de implementação e a fala do Diretor Geral sobre a política dos IFs que impõem um teto de professores para cada campus e, a depender dos eixos tecnológicos e cursos ofertados, alguns professores estarão sempre sobrecarregados em sala de aula enquanto outros terão uma carga horária mais compatível com suas atribuições.

A Portaria $n^{\circ} 17$ publicada recentemente pela $\operatorname{SETEC}^{34}$ dá a dimensão da otimização dos quadros de pessoal dos IFs ao estabelecer um mínimo de $10 \mathrm{~h}$ e o máximo de $20 \mathrm{~h}$ em sala de aula para os docentes EBTT. Além das atribuições de ensino, pesquisa e extensão, 66\% dos professores atuam ou já atuaram em cargos de gestão desde que tomaram posse no IFB. Os cargos incluem principalmente a Coordenação de Curso, Coordenação Geral de Ensino, Coordenação e Diretoria de Ensino, Pesquisa e Extensão. 34\% dos professores nunca assumiram nenhuma função de gestão. Significa que, com exceção da Direção Geral $^{35}$ que representa $4 \%$ dos cargos de gestão assumidos, os demais professores têm ou tiveram de compatibilizar as funções administrativas e de gestão com a docência verticalizada.

Some-se a esse fator a questão da quantidade de componentes curriculares que estão sob a responsabilidade de cada docente. Mais uma vez encontramos um cenário de disparidade, pois $38 \%$ dos professores lecionam três componentes curriculares

\footnotetext{
${ }^{34}$ SETEC Portaria n 17 de 11/05/2016 - publicada no DOU (Seção 01 - no 91, sexta-feira, 13/05/2016.

${ }^{35}$ Conforme a Resolução no $005 / 2016$, para o caso de docentes em exercício de cargo de direção poderá ser contratado um professor substituto.
} 
diferentes, 22\% lecionam dois componentes, $15 \%$ quatro componentes, $14 \%$ um componente, $6 \%$ cinco componentes e $5 \%$ dos docentes que lecionam seis ou mais componentes curriculares diferentes. Da mesma forma que a situação anterior, alguns professores estão sobrecarregados e outros estão com uma quantidade adequada de componentes para o bom desenvolvimento de suas muitas atividades. Considerando que os campi do IFB com menos de cinco anos de implementação ainda estão discutindo os planos de curso para cumprir as metas e exigências legais da verticalização, a questão das cargas horárias excessivas na docência e os múltiplos componentes curriculares tendem a ser agravados, contribuindo cada vez mais para um cenário de intensificação, individualismo e isolamento dos professores na estrutura escolar.

Outro aspecto que reforça essa questão é que os professores foram perguntados se o tempo que gastam nos diferentes conjuntos de tarefas docentes no IFB extrapola a carga horária de regime de trabalho semanal, 59\% responderam que sim e $41 \%$ afirmaram que não. A média entre aqueles que responderam positivamente é de $9 \mathrm{~h}$ a mais por semana. A frequência de professores que gastam entre $1 \mathrm{~h}$ e $8 \mathrm{~h}$ é maior do que aqueles que trabalham de $10 \mathrm{~h}$ a $20 \mathrm{~h}$ semanais a mais. Esses resultados indicam que a maior parte dos professores do IFB extrapola suas cargas horárias para dar conta das demandas da instituição, constituindo um dos elementos da intensificação do trabalho docente (APPLE, 1995; HYPÓLITO, 1999; CUNHA, 1999) e dessa forma "ainda que formalmente esteja estabelecido um regime de trabalho, com horas semanais a serem cumpridas, os professores estendem essa jornada, consubstanciando um tempo invisível nos registros oficiais." (GUIMARÃES; CHAVES, p. 569, 2015).

É curioso notar que nem todos os docentes têm clareza dessa intensificação uma vez que o percentual daqueles que se reconhecem intensificados quase se assemelha ao daqueles que não se reconhecem como submetidos a esse movimento, em suma "há certa aceitação desse processo pelos próprios professores." (Idem, p. 571). A adesão ao processo de intensificação se faz presente quando os professores se sobrecarregam para cumprir as exigências da instituição, assim como veremos na questão que se segue.

Ao classificarem o grau de satisfação com as atividades de gestão, ensino, pesquisa e extensão que desenvolvem no IFB, os professores se mostraram em sua maioria satisfeitos, pois $39 \%$ classificaram como bom, $33 \%$ razoável e $26 \%$ muito bom. Apenas $1 \%$ classificou como ruim e $1 \%$ como muito ruim. As ressalvas que os professores fizeram foram com questões específicas tais como a sobrecarga de trabalho que apareceu em primeiro lugar, seguida de falta de apoio ou condições para realizar 
pesquisa e extensão, logo depois vieram comentários a respeito da sobrecarga com atividades de gestão, as demandas administrativas que atrapalham o desenvolvimento docente e a falta estrutura nos campi ou estrutura precária. Os professores citaram especificamente melhorias que precisam ser feitas na biblioteca e a falta de salas adequadas para orientar os alunos, "Satisfação apenas na parte de ensino, não tive tempo suficiente para atuar em outras áreas.” (Prof. 05 CCEI) e

O tempo de preparação didática é curto se levarmos em consideração a diversidade de disciplinas e níveis em que dou aula. O tempo para pesquisa (pós-graduação) é insuficiente. Algumas atividades ocupam carga horária, mas não estão previstas nesta carga (avaliação de processos, por exemplo). (Prof. 04 CGAM).

A partir das falas dos professores, a questão que colocamos aqui é o conceito da verticalização - sendo uma experiência única na organização escolar, pois não há indicativos na literatura de uma mesma instituição realizando níveis e modalidades diferentes com um mesmo corpo docente - surgiu em um contexto de expansão do ensino técnico e superior com o intuito de buscar a otimização dos recursos, bem como promover a integração curricular desses diferentes níveis e modalidades. A política que criou os IFs e o conceito de verticalização e integração educacional, da maneira como está colocada, criou uma instituição educacional que oferece cursos superiores, mas não é uma universidade, tampouco escola técnica, leva à otimização dos recursos, ou seja, fazer o máximo de trabalho com uma quantidade mínima de professores. A contradição causada pela intensificação é que os professores devem aprender uma série de novas habilidades, mas não conseguem se manter atualizados nem em suas especialidades de formação (APPLE, 1995) nem nos aspectos relacionados à didática.

Talvez o ideal da verticalização e integração da educação básica ao ensino superior esteja restrito ao discurso de apresentação da política e convencimento de que se trata de uma nova forma de organização da educação, quando parece apontar para uma adequação das exigências de mercado pautado no modo de produção capitalista em sua fase neoliberal para a formação da classe trabalhadora em uma instituição educacional que sirva a vários propósitos, de maneira polivalente, adaptável e flexível, exigindo de seus docentes que realizem este trabalho sob condições desfavoráveis. Um modelo de instituição criado por uma política que não ouviu devidamente aqueles que iriam concretizá-la, não é de se espantar que nem todas as escolas federais aderiram ao 
projeto (OTRANTO op. cit.) que, entre outros problemas, produz grandes assimetrias no trabalho de seus docentes.

Dessa forma, consideramos como os elementos do trabalho docente na verticalização a intensificação, a satisfação e a insatisfação e as disparidades na carga horária, na formação e na remuneração.

No IFB, a concentração da carga de trabalho dos professores está no ensino, precarizando a pesquisa e extensão. Os professores demonstraram que o seu conceito de docência tem a ênfase na área do conhecimento e não na formação didática e pedagógica para atuação em cada nível e modalidade específicos. $\mathrm{O}$ isolamento docente também apareceu como um dos elementos do trabalho, assim como a fragilidade no movimento associativo dos professores, resultando em ações individuais tanto em termos de ação pedagógica quanto na busca por formação, trazendo para si essa responsabilidade. Ao mesmo tempo, contraditoriamente, há tanta necessidade de formação para os professores, mas não há tempo disponível para todos pela desigual divisão de carga de trabalho seja no ensino ou na gestão. A dificuldade de integração entre os pares pode ser vista também como um elemento do esvaziamento da integração educacional que é proposta para os IFs. Assim, temos uma docência polivalente, flexível e adaptável, com relativa autonomia dos professores na qual a satisfação e a insatisfação ocorrem ao mesmo tempo. A verticalização real trouxe demandas aos professores, mas não oferece as condições para sua realização.

O trabalho docente, para Tardif e Lessard (2013) pode ser analisado a partir das "atividades materiais e simbólicas dos trabalhadores tais como elas são realizadas nos próprios locais de trabalho" (p. 37), levando em conta a totalidade dos componentes do trabalho passaremos à próxima unidade de análise que trata dos estruturantes do trabalho docente na verticalização, abordando os limites e possibilidades da docência no IFB.

\subsubsection{Estruturantes do trabalho docente na verticalização}

A integração do ensino médio ao superior é parte constituinte do modelo curricular dos IFs e uma das diversas responsabilidades a serem cumpridas pelos professores em seu trabalho docente no IFB. Partindo dessa questão, os professores foram perguntados se se sentiam preparados para atuar ao mesmo tempo na educação 
básica, na modalidade profissional e na educação superior. A maioria dos professores, $45 \%$, responderam que se sentem preparados, $38 \%$ dos professores responderam que se sentem preparados em parte e $17 \%$ disseram que não se sentem preparados.

Nos comentários sobre essa questão a maior incidência foi a fala dos professores alegando não terem formação para atuar no nível superior, seguido dos professores que disseram estar preparados, pois já têm experiência anterior na docência e são flexíveis; a terceira maior incidência foi de professores alegando dificuldades em abordar os conteúdos em níveis e modalidades diferentes, alguns destacaram que o ideal seria atuar em apenas um nível. Outros professores indicaram que a atuação integrada e verticalizada é uma questão de adaptação da linguagem e aprofundamentos dos conteúdos. Os professores também assinalaram a necessidade de formação continuada e a falta de tempo para tantos planejamentos diferentes.

Cada um desses níveis e modalidades da educação têm suas especificidades, seja nos objetivos do que se espera de cada um deles, na preparação didática, ou nas relações de ensino e aprendizagem que se estabelecem em adolescentes ou em adultos. Essas questões não foram abordadas pelos professores em seus comentários uma vez que a maior importância foi dada à titulação para poder atuar no ensino superior ou à flexibilidade que as experiências prévias proporcionaram e não a formação específica para a docência, caracterizando-a como dispensável para o exercício do trabalho de ensinar.

Ao falar sobre a verticalização do ensino médio até o ensino superior conforme é proposta pelos IFs, os professores destacaram a possibilidade de o aluno iniciar os estudos em um curso técnico e seguir para a pós-graduação, ou seja, a perspectiva de construção de um itinerário formativo dentro do IF foi a resposta com mais frequência nas entrevistas e se revela, na verdade, como uma vantagem para o corpo discente.

Ao se falar sobre o trabalho docente na verticalização, as respostas trataram também sobre as dificuldades, entre elas reconhecer os saberes dos alunos de um nível para outro. $\mathrm{Na}$ fala do professor a seguir podemos perceber a falta de integração existente entre os docentes e alunos dos dois níveis:

Eu acho que seria interessante que houvesse um diálogo maior entre as duas, pelo menos entre elas. Ou de quem fizesse superior pudesse trabalhar com o ensino médio e o ensino médio também pudesse ter uma noção do que é pesquisa, iniciação científica, por exemplo. Coisa que não há hoje, não há um diálogo entre, muitas vezes nem entre os professores das modalidades e muito menos entre os 
alunos. No intuito de fazer uma coisa um pouco mais integrada. Então eu acho que seria interessante se houvesse essa integração. (ProfSindi).

A necessária integração entre os professores nos IFs para que ocorra a verticalização tem se mostrado recorrente. Em recente estudo com professores do Instituto Federal da Paraíba (IFPB) a respeito da integração curricular nos cursos técnicos integrados ao ensino médio, os pesquisadores apontaram que as dificuldades para a integração curricular estava relacionada à "falta de conhecimento dos projetos dos cursos técnicos; falta de experiência coletiva; dificuldade de convergência de conteúdos para um mesmo curso e como integrar docentes de distintas disciplinas técnicas, sem encontros por áreas e cursos.” (QUEIROGA; SILVA, 2014, p. 104).

Nesse sentido o excesso de componentes curriculares foi mencionado como fator que pode sobrecarregar alguns professores de determinadas áreas:

É uma possibilidade maravilhosa. Eu vejo como maravilhosa. Só que quando a gente vai praticá-la, se a gente desconsidera algumas questões, essa expectativa toda de fazer algo único e diferenciado, por exemplo, ter o quadro com professores que vão dar aula para o PROEJA, dentro do quadro você ter $30 \%$ do quadro Doutores, mais aí $50 \%$ de mestres e alguns especialistas. Onde tem isso? No país? Não tem. [...] Então, na prática, o formato do Instituto joga a gente nessas armadilhas, então eu acho que o problema não está na verticalização em si, está no que foi usado de ferramental e aí eu não estou tentando buscar culpa, porque realmente quando você entra com a transparência, a necessidade de prestação de contas e você reconhece que é uma equação difícil e você chegar a um resultado razoável, mas a gente tem esse desafio para tentar resolver ao longo do tempo. A verticalização eu continuo vendo com bons olhos, agora, como a gente atua nessa verticalização, a gente ainda está sem ferramental para atuar de forma vertical sem que a gente caia, sem ter o descrédito da qualidade das aulas e sem que a gente nos desestimule, porque se você começa a sentir que sua aula deveria ser melhor do que você está praticando, por estar nesta situação, chega uma hora que você começa a se desestimular e o risco é você dar, aquilo que acontece no país inteiro, aquela mesma aula de sempre, com aquela mesma vontade que é o que a gente sonha em sair, ultrapassar um pouco esse modelo. (ProfDG).

A verticalização traz a possibilidade de que professores titulados atuem em programas como o Proeja, porém, da maneira como está organizada a política, o limite de professores por campus inviabiliza uma divisão mais equitativa da carga horária 
docente e da quantidade de componentes curriculares para cada docente. Nas respostas dos professores a possibilidade de ter experiência em várias áreas também surgiu nos comentários:

Eu acho muito bom porque você pode ter experiência em várias áreas. Mas isso exige de você maior conhecimento, porque eu tenho aula no curso superior à tarde e à noite eu vou para o técnico, depois eu vou para o Ensino Médio se for o caso, eu preciso ter conhecimentos específicos pra área e isso demanda mais de mim também. Por fora até, de pesquisar, de correr atrás. (Prof. 01).

Destacamos na fala da Prof. 01 a importância dos conhecimentos sobre o ensino e aprendizagem e não apenas o domínio dos conteúdos curriculares para cada nível e modalidade. A professora ainda dá a entender que depende dela e não da instituição a busca pela qualificação para dar conta da polivalência, ou seja, desempenhar várias tarefas no seu local de trabalho. A polivalência por nível de ensino é um dos elementos que estruturam o trabalho docente do IFB, bem como de todos os outros Institutos Federais. Nesse sentido, concordamos com os pesquisadores do Instituto Federal de Alagoas (IFAL) ao afirmar que nessa situação "o trabalho desse docente não possua uma identidade própria, tendo ele que reorganizar a sua prática educativa para atender a toda essa diversidade educacional, que requer estudos e metodologias próprias para cada nível e modalidade de ensino.” (GOMES; BRASILEIRO; LIMA, p. 24, 2014).

Ainda na questão da integração curricular, os professores foram perguntados sobre como fazem a transição do currículo do ensino médio para o ensino superior. Nas respostas, a maior frequência das falas foi sobre a dificuldade em ter alunos no nível superior que já cursaram o nível técnico no IF, pois a turma fica heterogênea, ou seja, alguns alunos que estão cumprindo o itinerário formativo no IFB já têm conhecimentos sobre determinado componente, enquanto outros alunos advindos de outras instituições ainda não entraram em contato com determinados conhecimentos.

Os docentes também mencionaram que fazem a transição dos currículos de acordo com os objetivos de cada curso, de nível médio e de nível superior e se apoiam na legislação e outros normativos. O perfil de profissional que as empresas desejam apareceu como parâmetro para decidir o que seria ensinado em cada nível. Por fim, o nível de conhecimento da turma foi apontado também como forma de abordagem. Destacamos a fala do professor e coordenador de curso que explica como realiza a transição: 
Eu verifico quais são os intuitos, qual é o objetivo maior desse curso? Tendo em vista que é da minha área de formação, então fica mais fácil compreender qual a função do técnico e qual a função do nível superior. Nesse sentido, eu foco no que a legislação exige pra formação do nível superior e foco no que a legislação exige para o nível técnico. Então qual é o perfil desse profissional, o que ele vai fazer, pra quê que ele está se formando? $\mathrm{E}$ com base nisso que eu tento trazer as aulas de acordo com esse perfil. Então, por exemplo, no técnico, trabalha-se mais o operacional, todavia, eu tento propiciar pra o aluno saberes e conhecimentos que vão além do operacional, para futuramente eles poderem caminhar dentro da empresa, até porque se sabe que empresas de pequeno porte, pequenas empresas, microempresas, o secretário ele é o RH, ele é o marketing, ele é o gerente, ele é tudo, ele é o financeiro. Então ele tem que ter um domínio além do operacional, ele tem que ter um domínio no mínimo tático. Já no nível superior, como é exigido dele um perfil diferenciado de liderança, de gestão, de consultoria, de empreendedorismo, de assessoria, ele precisa ter uma formação bem mais ampla. Ele precisa desenvolver uma quantidade maior de competências e habilidades. Então o conhecimento, os saberes que propiciamos dentro de sala ele tem que ser favorável ao desenvolvimento de novas competências e novas habilidades. (Prof. CoordSup).

É interessante notar que no caso do professor e coordenador de curso que ele destaca o fato de atuar na sua área de formação. Essa parece ser uma dificuldade dos professores do IFB ao atuarem em cursos técnicos e superiores para os quais eles não necessariamente têm formação ou experiência profissional. Os professores disseram em sua maioria, $56 \%$, ter experiência profissional no eixo tecnológico oferecido pelo seu campus, porém, uma grande quantidade de professores $44 \%$, afirmaram não ter essa experiência.

Esse parece ser um critério fundamental para lecionar na modalidade de EPT, uma vez que o Documento Base (BRASIL, 2007) que trata da educação profissional técnica de nível médio integrada ao ensino médio indica que os professores devem ter formação que inclua os conhecimentos específicos de uma área profissional, junto com a formação didático-político-pedagógica e a integração entre a EPT e a educação básica. Souza (2013) afirma que para os professores que atuam na EPT a formação continuada em programas stricto senso em parceria dos IFs com universidades seria uma perspectiva, uma vez que os professores formados em física, biologia, língua portuguesa etc. "pudessem alcançar maior clareza sobre a necessidade de uma atuação docente capaz de articular científica e tecnologicamente os respectivos conteúdos curriculares com os quais trabalham" (p. 398) colocando em primeiro plano a compreensão pelos 
alunos das dimensões políticas, tecnológicas, econômicas, científicas e culturais de modo a se posicionarem como sujeitos históricos.

Considerando que o trabalho do professor caracteriza-se primordialmente pelo ensino, o par dialético trabalho-formação se sobressai quando se trata da educação profissional. Além das características do trabalho docente em geral que, conforme Melo (2010) envolvem a regência de classe, o planejamento, a gestão da escola e a discussão coletiva do currículo e da avaliação, o trabalho docente na EPT se soma a essas características e ainda tem elementos que ampliam a sua complexidade. A natureza do ensino técnico

compreende atividades teóricas e práticas mais contíguas, e, por conseguinte, requer espaços físicos diferenciados além de salas de aula, como laboratórios, oficinas e, muitas vezes, ambientes externos do campo profissional. Exige ainda tempos e relações distintas entre professores e alunos, sobretudo nas aulas práticas, organizadas em grupos menores de alunos; visitas técnicas a contextos reais de atuação profissional; estágios supervisionados; orientações em projetos, pesquisas aplicadas, entre outras. Essa variabilidade traz implicações para o trabalho docente, conferindo-lhe maior flexibilidade e proximidade na relação com os estudantes e com outros contextos e ambientes de trabalho (MELO, 2010, p. 2).

Duas professoras enfatizaram a diferenciação entre os componentes curriculares do nível superior, médio e modalidades como o Proeja, ressaltando a questão de buscar nos discentes o referencial para definir o nível de aprofundamento do conhecimento. Destacamos aqui a fala de uma das professoras:

O ensino superior já tem as suas especificidades, não é? Linguística aplicada e fonética. Então alunos mais específicos, mas para o PROEJA que teria no ensino médio, então a mesma aula que eu dou pros meninos eu teria que aplicá-la ao PROEJA, isso não foi verdade. Eu não consegui, acho que não dá pra fazer, são realidades diferentes, são mundos distintos. Então, eu conversava muito com os alunos pra verificar mesmo o que é que eles achavam da minha aula, qual que era a avaliação deles com a minha aula, o que é que eles esperavam. (Prof. 03).

A transição do currículo feita por esses professores se dá no nível do aprofundamento, que é diferente para o técnico de nível médio e o aluno de curso superior.

Então, aí que vem o problema, por que assim, vou falar da minha experiência dentro do vestuário. [...] O que acontece é que a gente teve obrigação de abrir o nível técnico do vestuário, a gente tentou puxar, mesmo o nível técnico, pra área do design, pra outra linha, 
que é a linha de produção e design, mas não foi permitido. Então o técnico em vestuário é na linha do industrial. Então, ali a gente começou pelo FIC, até aí foi tudo bem, depois foi para o nível técnico que aí a gente só veio a entender depois que tava fora do nosso eixo tecnológico. O eixo tecnológico do design do curso técnico do vestuário é o eixo industrial e o eixo tecnológico da área de onde nós passamos no concurso é produção e design. Aí o que aconteceu, além disso, a gente continuou dando a aula do nível técnico, o FIC junto. Pra gente tentar essa verticalização foi até uma iniciativa do próprio campus, foi que, ao invés do aluno passar por sorteio, que até então foi muito questionado por nós lá na época. Para o nível técnico, a gente usou o FIC como uma introdução para o técnico. Então para o aluno do FIC, eles entravam como sorteio. Só que eles faziam matérias, onde essas matérias o auxiliariam pra quando ele entrasse no curso técnico do vestuário. Então ele ia direto. Ele passando em todo o FIC, ele ia direto para o curso técnico. Então o FIC alimentava o nosso técnico. Até então foi ótimo, porque a gente conseguia nivelar muitos alunos e aí a gente conseguia dar um empurrão pra eles entrarem nessa área.

[...] Ai, o que aconteceu nesse meio tempo a gente ficou, FIC alimentando técnico, até aí tudo ótimo, a gente conseguiu ver a verticalização do ensino, foi muito bacana. Aí a gente começou a estudar o nível superior pra montar o plano de curso. Só que o nível superior não é do mesmo eixo tecnológico. Não é que eles não se conversam, eles se conversam, até porque um designer de moda precisa de um técnico de vestuário pra produzir a roupa. Mas são eixos diferenciados. Como que eu faço essa pessoa pular essa ponte? Porque é uma ponte enorme, é quase um abismo, entre um nível, um eixo tecnológico industrial pra ir pra uma produção e design? Então foi complicado, realmente entendo de conhecimento, a gente tá apontando, não é o ideal, mas eu não sei. Ai o que aconteceu? Com a abertura do curso técnico, do curso superior de design de moda, a gente observou isso na real, que seria muito complicado fazer essa situação, então se começou a estudar uma possibilidade de rever o curso técnico do vestuário. Tentou uma e tentou duas eu acredito que esteja já fazendo esse estudo. (Prof. 02).

A Prof.02 critica mais tarde a decisão do IFB de que os alunos dos cursos técnicos fossem escolhidos por meio de sorteio e não mais por meio de processo seletivo via curso FIC. De acordo com a professora, isso dificultou a realização da verticalização, uma vez que em sala de aula havia alunos que haviam passado pelo FIC e tinham conhecimentos prévios do eixo tecnológico e outros alunos que nunca haviam estudado o assunto.

A mesma professora relata os obstáculos em realizar a verticalização com cursos que são de eixos tecnológicos diferentes, pois o aluno passa pelo curso FIC, logo em seguida iria para o curso técnico de nível médio e depois para o curso superior, porém, o curso de nível médio e de nível superior não estavam no mesmo eixo, o que dificultou a transição tanto para os professores quanto para os alunos. A docente fala da 
complexidade em ter alunos no curso superior que já cursaram o nível técnico no campus, pois a turma se torna heterogênea, uma vez que muitos dos aprendizados adquiridos no curso técnico irão se repetir nos cursos superiores, conforme a fala:

Isso é desesperador. É horrível, porque na verdade você tenta acender vela pra dois santos. É muito complicado, é muito complicado. [...] Tanto que a própria ementa fala que a modelagem tem que ser básica, só que como eu dou a modelagem básica pra um aluno que estudou um ano e meio comigo e ele não é mais básico. Só que ao mesmo tempo eu tenho sessenta, setenta por cento da turma que já passou por isso e trinta por cento que nunca viram, não sabem pegar numa fita métrica. Então, realmente a situação é muito difícil pra aproximar esses dois mundos. O que eu tentei fazer na minha situação, para que a aula não fosse tão entediante para as pessoas que já sabiam e que também não fosse tão desesperadora para as pessoas que não sabiam nada, eu misturei pessoas de conhecimentos pra umas ajudarem as outras. (Prof. 02).

A professora relata uma estratégia em sala de aula para reduzir o desgaste da turma heterogênea que é reunir grupos de alunos para dar conta da diversidade de níveis de conhecimento em sala de aula, ou seja, aqueles alunos que já estavam traçando um itinerário formativo no campus em questão e os demais alunos recém-chegados.

Os professores ao serem perguntados sobre quais estratégias didáticopedagógicas são desenvolvidas para estabelecer a gradação de um mesmo conteúdo entre os diversos níveis e modalidades que atuam responderam em sua maioria que se utilizam principalmente de dois procedimentos: i) a variação das estratégias e atividades de ensino e ii) a identificação das características de cada nível por meio da realização do diagnóstico da turma. A fala do professor do campus Riacho Fundo ilustra bem essas duas formas ao afirmar "Seleciono textos com abordagens diferentes, desenvolvo atividades segundo o ritmo das turmas e busco levantar o conhecimento prévio dos aprendizes para saber como abordar as discussões.” (Prof. 05 CRFU).

A terceira estratégia mais citada pelos professores foi a questão da profundidade dos textos, que aumenta conforme o nível, principalmente para o nível superior. O professor explica "Nas modalidades superiores é cobrado maior leitura e profundidade da participação.” (Prof. 04 CSSB). Empatadas em quarto lugar há três estratégias, a saber: i) o uso de uma linguagem acessível ou adequada para cada nível e modalidade, ii) o uso de exemplos próximos da realidade de cada nível com a aplicação do conteúdo e iii) o aumento da profundidade e complexidade dos conteúdos gradativamente. Outra fala ilustra essa situação "Tento adequar os exemplos, no EMI faço atividades mais 
lúdicas" (Prof. 17 CSSB), enquanto o professor do mesmo campus explica "Utilizo nos cursos técnicos aulas mais dinâmicas com jogos e atividades práticas. No curso superior há um peso maior na fundamentação de conceito.” (Prof. 09 CSSB).

Análogo ao conceito de "profissionalidade polivalente" na qual "a característica do professor que, ao atuar em determinado nível de ensino, leciona diversas áreas de conhecimento do currículo da educação básica" (CRUZ, p. 91, 2012), a polivalência por nível de ensino faz o professor lecionar diversos componentes curriculares em níveis e modalidades diferentes. Assim como o professor polivalente do ensino fundamental, o professor na polivalência por nível de ensino do IFB estabelece uma relação com os conteúdos curriculares e as estratégias e atividades de ensino e linguagem específicas para cada público, expressando um nível de autonomia no seu trabalho como professor em sala de aula. Dessa forma, a construção dessa relação "reflete a construção cotidiana do professor empreendido em cumprir com o seu ensino, ou seja, do modo como vive sua profissão, que lhe demanda polivalência para lidar com as diversas áreas de conhecimentos e fazer seus alunos aprenderem" (Idem, p.91). Esse parece ser um indicativo de um estruturante do trabalho docente na verticalização, o saber curricular (SAVIANI, 1996) como integrador dos conhecimentos didático-pedagógicos e os dos componentes curriculares de referência.

Já a menor frequência de respostas para a questão da transição curricular envolveu aqueles professores que por enquanto atuam em apenas um nível, os professores que não veem diferença entre o ensino nos cursos FIC e cursos técnicos, professores que apenas repetem o conteúdo independente do nível e professores que ainda não conseguiram resolver essa questão da gradação entre os níveis. Ou seja, a não realização do trabalho verticalizado não possibilitou a esses professores pensar a respeito dele, da mesma forma que a vivência direta da verticalização sem uma formação adequada para a docência apresentou-se como um obstáculo de modo a inferir em como pensam em realizar o trabalho verticalizado, uma realidade a que todos os docentes estão sujeitos no IFB.

A verticalização nos IFs traz consigo limites e possibilidades. Sobre essa questão e suas implicações para trabalho docente há a relação professor/aluno em termos quantitativos. Considerando que IFs oferecem desde cursos FIC até pós-graduação, as normativas que regem os Institutos Federais consideram o número total de alunos por campus como metas a serem alcançadas. Em auditoria (CGU, 2014) realizada no IFB o texto faz alusão ao Termo Acordo de Metas e Compromissos (TAM) celebrado entre o 
MEC e cada instituição da RFEPCT, no qual é citada a meta $n^{\circ} 3$ do TAM a qual prevê uma relação de 20 alunos regularmente matriculados nos cursos presenciais por professor. Os limites e as possibilidades ficam então evidentes na fala do professor e gestor:

Logo, a gente é pressionado e é induzido a cair numa racionalização, por exemplo, a última portaria que o MEC emitiu que tem a classificação dos campi, na qual ficamos com o teto de setenta professores, quarenta e cinco técnicos administrativos e numa relação de vinte alunos por professor, essa é a bendita relação, vinte alunos para cada professor, teríamos que ter mil e quatrocentos alunos no campus. De modo geral, é factível, mas se a gente for manter essa proporção para um curso de Doutorado, passa a ser absurdo. Para FIC, para algumas modalidades, isso se dá. Então, a proposta é ousada, a proposta é romântica. (Prof-DG).

A ousadia e o romantismo da proposta dos IFs, termos usados pelos participantes da pesquisa, esbarram em suas condições objetivas de execução, uma vez que, por ter estrutura otimizada e estar sujeita a rigoroso controle de metas a instituição colide com impasses para a realização da verticalização e integração da educação com um mesmo corpo docente. O mesmo professor prossegue sua fala sobre a questão da prestação de contas para a sociedade e comenta o fato de como apenas os resultados numéricos podem ser inadequados para avaliar uma instituição que se propõe a fazer a verticalização e integração educacional de níveis e modalidades distintas.

Não à toa, por que há a necessidade de prestar contas para a sociedade, é muito recurso investido e a gente meio que, na hora de prestar conta tem meio que uma tara por números e a sociedade cobra números e a gente sofre na hora de executar, porque tem algumas coisas que a gente tem que esmagar para caber no formato numa caixinha. Então, a concepção da Rede é tão ambiciosa, tão romântica, tão cheia de possibilidades maravilhosas quanto o inverso na dificuldade ou quase impossibilidade de ela ser feita como concebida. E a gente corre para tentar ajustar para fazer o que dá. (Prof-DG).

Do ponto de vista do gerencialismo (MAGUIRE; BALL, 2011) a escola relaciona o seu desempenho diretamente aos incentivos materiais, ao mesmo tempo em que a autonomia dos professores é celebrada, os processos decisórios são transferidos para o âmbito externo. Ainda segundo os autores, nesse sistema nem os especialistas em educação nem os professores são consultados sobre políticas que afetarão diretamente 
seu trabalho, como no caso do IFB no qual os recursos são derivados da quantidade de alunos matriculados versus a quantidade de professores em cada campus. Assim, o modelo de financiamento per capta "conjuntamente com os modelos competitivos de negócios e empreendedorismo, têm reduzido a autonomia escolar ao exercício de contabilidade institucional, manipulação de imagem e resposta reativa." (Ibidem, p. 182).

Os professores foram então perguntados a respeito dos limites e possibilidades que a verticalização apresenta para seu trabalho, no qual destacamos duas falas. A primeira fala é da Prof. 02:

Bom, a possibilidade é que eu consigo ser mais "Bombril" assim, eu consigo atuar de forma mais dinâmica nas várias áreas, isso é um lado bom. O lado ruim é que eu não consigo ser tão boa em uma área, porque se eu escolhesse uma área só, eu ia me dedicar exclusivamente aquele momento. E seria um top naquele ponto, mas como eu tenho que abraçar os três, eu acabo sendo mais ou menos em cada um, não tem como você focar em ter os três com a mesma qualidade que você teria só um. E isso é muito difícil. (Prof. 02).

Novamente a categoria polivalência surge como um estruturante do trabalho docente na verticalização. O professor polivalente deveria estar apto a transitar pelos diferentes cursos oferecidos por seu campus, porém, ao ter seu trabalho docente comparado a um "Bombril", o professor tem de percorrer várias áreas, mas não consegue ter excelência em nenhuma delas, atuando de maneira superficial, sem tempo para se dedicar à pesquisa e extensão e sem formação pedagógica para atuar em níveis e modalidades considerando suas especificidades. Assim, a "competência multifuncional" do professor flexível capaz de atuar em diversas áreas se destaca por sua flexibilidade funcional, característica do "mundo do trabalho, requisitado pelo discurso neoliberal no período pós-crise do capitalismo" (CRUZ, op. cit. p. 110).

A questão da dedicação dos professores a áreas diversas aparece também como um empecilho para o aprofundamento no desenvolvimento de suas atividades. O estudo que envolveu 12 IFs abrangendo todas as cinco regiões do Brasil (Dias et. al., 2016) apontou que:

É importante o estabelecimento de divisão de trabalho em cada campus, respeitando os perfis de habilidades e preferências dos membros do quadro docente, para a instituição melhor desempenhar suas atividades e cumprir suas finalidades e objetivos, estabelecidos em lei (incluindo necessariamente implantar e/ou ampliar atividades 
de apoio à inovação tecnológica, desenvolver e transferir tecnologia). (p. 6).

O Prof.CoordSup apresenta outros elementos dos limites e possibilidades da verticalização:

\begin{abstract}
As possibilidades é você ter mais tempo de trabalhar as potencialidades dos alunos tendo em vista que você vai trabalhar com ele no técnico e depois ele passa pro superior, você vai ter o mesmo aluno, você já vai conhecer o perfil, já vai conhecer as potencialidades dele e poder trabalhar com isso, otimizar isso.

[...] Os limites seria a falta de tempo mesmo, pra você fazer todo esse trabalho. A falta de uma formação pra isso, uma formação continuada, pedagógica, uma formação de trabalho, como fazer isso. E os limites é correr o risco de você fazer uma formação lá no curso superior técnica, ou você fazer no técnico uma formação superior. Por não ter esse conhecimento e habilidade para transitar, saber transitar entre os níveis. É isso. (Prof.CoordSup).
\end{abstract}

As possibilidades da verticalização mais uma vez aparecem para o corpo discente que pode ter o acompanhamento do mesmo professor que o ensinou no curso técnico e, posteriormente, pode acompanhá-lo no curso superior. Esse acompanhamento pode resultar em uma visão integral do aluno que vai percorrendo o itinerário formativo dentro da instituição. O tempo e a interação que o professor pode dedicar ao aluno é um destaque da polivalência por nível de ensino na fala dos docentes e, de maneira contraditória, o tempo também é limitante, pois para acompanhar a aprendizagem dos alunos é necessário tempo de planejamento.

As respostas dos professores sobre os limites e as possibilidades da verticalização mesclam-se com os elementos positivos e negativos na verticalização. Podemos perceber isso na fala dos professores ao expressar os pontos positivos na verticalização dos Institutos Federais:

Possibilitar a permanência e a formação de pessoas que muitas vezes não tiveram oportunidade no período adequado, então de formação básica e superior, possibilitar essas pessoas ir além e transformar sua realidade. (Prof. CoordSup).

A possibilidade de conhecer as outras áreas, o próprio trâmite, o professor ele ter a experiência nos níveis. No técnico, no médio, mas eu não consigo ver além. (Prof. 01).

A maior prevalência de respostas foi para a possibilidade de atuação em diferentes níveis e modalidades de ensino, seguido da oportunidade de os alunos 
traçarem um itinerário formativo dos cursos FIC até os cursos superiores empatado com a perspectiva de aperfeiçoamento na área de atuação, ou seja, o professor segue estudando. Em terceiro lugar os professores disseram que atingir vários níveis sociais e alunos com perfis diferentes era uma vantagem, assim como atuar na verticalização trazia vantagem salarial e um plano de carreira interessante por atuarem também no nível superior.

A relação professor-aluno mostra-se importante para os docentes, conforme destacamos nas falas do professor 02 do campus Samambaia ao afirmar como vantagem “Compreender os estudantes em diferentes níveis epistemológicos e poder acompanhar o desenvolvimento de cada um.”. Já o professor 05 do campus São Sebastião percebe a polivalência por nível de ensino ao afirmar "Entender como funciona cada modalidade e perceber onde o nosso trabalho pode ser mais bem desempenhado.”. A relação com o aluno parece ser um elemento de incentivo para o professor ao observar o desenvolvimento discente dentro da instituição como um reflexo de seu trabalho.

Falar sobre o professor que reconhece o reflexo do seu trabalho no aluno é falar também sobre a relação escola-sociedade. Não é possível perceber nos comentários dos professores uma clareza quanto ao contexto da educação profissional, mas principalmente compreensões incipientes sobre o mercado de trabalho e pouco sobre o trabalho como princípio educativo. Tal qual a questão do fator tempo como o estruturante da relação escola-sociedade foram debatidos no estudo de Cruz (2012) sobre a profissionalidade docente polivalente no ensino fundamental, já mencionado em nosso texto. Esses aspectos parecem, dessa maneira, endossar que tanto a marca da ambiguidade como a clareza de um projeto político-pedagógico para a docência a ser exercida são elementos característicos da marca da polivalência no trabalho docente realizado assim como o é o trabalho do professor no contexto da verticalização.

As demais citações envolvem a formação de colegiados de professores, a possibilidade de atuar no nível superior, o aproveitamento dos conhecimentos prévios dos alunos, ter mais tempo para trabalhar com o aluno, o aproveitamento de estudos dos alunos e diminuição de alunos em sala de aula, bem como a diminuição da evasão. Mesmo perguntados das vantagens da verticalização para o seu próprio trabalho, diversos professores citaram vantagens da verticalização para os alunos.

A respeito dos elementos negativos na verticalização dos Institutos Federais os professores citaram: 
Com essa verticalização aumenta-se o número de alunos, e aumentando o número de alunos, aumenta o número de aulas, aumenta o número de turmas, aumentando o número de aulas, tendo em vista que nós estamos fechados em um número específico de docentes, aumenta a quantidade de aulas por docente impossibilitando um planejamento adequado, então, é uma dificuldade. (Prof. CoordSup)

E o professor acaba sendo também, mais ou menos. Ele é mais ou menos bom em tal coisa, em tal coisa, em tal coisa. Ele não é $\mathrm{O}$ melhor em tal coisa. Isso eu acho ruim de abraçar esses três mundos aí. (Prof. 02)

Você aproveita um recurso humano, você otimiza, que é o termo mercadológico, você pega um professor que ele é da educação básica, ele é do superior, ele não vai reclamar, assim, a gente até acaba virando, assim, em outros espaços, é motivo do pessoal falar "A carreira docente dos Institutos Federais, eles não reclamam, porque eles vivem relativamente melhor do que a básica, que tá mesmo na educação básica, tem a tal da RSC, eles não têm o sindicato forte, em função dessa verticalização. Pro aluno é muito bom ver a verticalização do ponto de vista discente eu só vejo vantagem, é muito bom a gente ver o aluno falando que sai do FIC e ele tá na graduação. Isso é importante, mas aí o aluno vê também o professor, o professor acompanha. E tem alunos que eu tava observando isso no Tecnólogo, que eles falam "Poxa é o mesmo professor do técnico?". E aí ele vê numa posição as vezes de subvalorização, mas aí também, eu responsabilizo o docente, dele mostrar pro aluno que é uma outra postura e que tem um nível de aprofundamento maior, no geral é isso. (Prof. 01).

Os elementos negativos na verticalização apontam para as condições concretas de trabalho. Em estudo realizado por Nogueira (2012) com professores da rede pública de ensino foi identificado que grande parte das "frustrações e desapontamentos" dos professores "está enraizada nas condições concretas de trabalho produzidas pela organização institucional, como sobrecarga de trabalho, grande número de alunos em sala de aula, ausência de materiais para as aulas" (p. 1238). A mesma autora também destaca estudos da Confederação Nacional dos Trabalhadores em Educação (CNTE) que corroboram a fala dos professores do IFB no sentido de que as condições de trabalho são essenciais para a realização da docência, não importando o nível ou modalidade, e não seria diferente para a verticalização dos IFs que para ser viabilizada necessita de condições adequadas.

Os professores ao serem perguntados sobre as desvantagens da verticalização para o seu trabalho responderam em maior quantidade que a dificuldade é trabalhar em diferentes níveis e modalidades de ensino, contraditoriamente, o exato oposto do que 
apareceu como a maior vantagem na questão anterior. Em segundo lugar, os professores alegaram não realizar um trabalho bem feito por atuar em áreas diversas, em terceiro lugar, empatados estão a questão de assumir funções de gestão e outras atividades em conjunto, excesso de atividades, rotina desgastante e falta de tempo para o planejamento foram apontadas como desvantagens. A mesma quantidade de professores disse não haver desvantagens na verticalização e um deles ainda acrescentou "Não há desvantagem desde que feita conforme consta em lei." (Prof. 02 CTGC). Os demais professores citaram a necessidade de reorganização dos conteúdos de acordo com o nível e modalidade de ensino, a falta de formação do professor para o nível e modalidade, o baixo salário não compatível com o nível de especialização exigido e os déficits escolares dos alunos. Mais uma vez as condições de trabalho surgem como elementos que dificultam a realização da verticalização.

Sobre a dificuldade em trabalhar em diferentes níveis e modalidades de ensino, ainda nos estudos realizados pelos pesquisadores do IFAL há a afirmação de que "o ideal seria que os profissionais ligados às licenciaturas fossem dedicados apenas à formação de professores, para que o curso tenha uma verdadeira identidade e funcione como planejado" (GOMES; BRASILEIRO; LIMA, p. 26, 2014), mas os próprios pesquisadores questionam se isso seria possível em um IF e finalizam afirmando que essa é uma situação que gera "falta de identidade não só do profissional como também das próprias licenciaturas" (Idem, p. 27). A polivalência por nível de ensino trazida pela verticalização não é um consenso entre os professores dos IFs. Trata-se de uma situação nova, que é afetada diretamente pelas condições de trabalho como falta de formação para atuar em todos os níveis e modalidades, falta de infraestrutura adequada, carga horária excessiva no ensino e sobreposição da docência com tarefas de gestão.

Os elementos positivos nas entrevistas são marcadamente voltados para o acesso e permanência de uma determinada parcela da população na educação básica à superior. Alguns professores também consideram positivo o fato de terem a oportunidade de conhecer outras áreas. Essa mesma possibilidade faz com que haja uma diversidade maior de componentes curriculares, forçando a atuação polivalente dos docentes, que faz com que eles não sejam especialistas em uma determinada área, além do tempo necessário para realizar diversos planejamentos.

Os elementos positivos nos fazem perceber que a expansão dos IFs "levou o ensino técnico aonde não chegava, e atende a quem nunca foi atendido, porém não chegou com a forma adequada e não atende como se esperava." (MARINHO; COSTA, 
2013, p. 10). Podemos perceber que as falas dos professores se repetem entre limites e possibilidades, vantagens e desvantagens, voltando para as condições de trabalho e para a política educacional que criou os IFs e expandiu o acesso a educação profissional e superior.

Dessa maneira, os estruturantes do trabalho docente na verticalização aparecem relacionados com os eixos de formação docente, integração e verticalização e as condições de trabalho.

A integração educacional encontra-se ligada à formação docente, uma vez que nem todos os professores se sentem preparados para atuar em todas as frentes oferecidas pelo IFB. A flexibilidade surgiu como um estruturante do trabalho docente, no qual seria mais importante ter experiência profissional do que a formação para o magistério.

A possibilidade da realização de um itinerário formativo para o aluno do IFB na verticalização foi um ponto positivo destacado pelos professores, mas apareceu também como uma dificuldade para os professores realizarem a transição curricular de um nível para o outro com os mesmos alunos. Essa transição curricular nos leva à necessidade de integração entre os professores para que a verticalização se concretize e, mais uma vez, a intensificação do trabalho surgiu como um obstáculo para a sua realização.

Assim, temos a polivalência por nível de ensino como um estruturante do trabalho docente na verticalização, na qual todos têm de atuar nos diversos níveis e modalidades com suas respectivas peculiaridades. Essa polivalência é também contraditória para os docentes do IFB, uma vez que ela é vista como vantagem e desvantagem para o trabalho. A verticalização, ao mesmo tempo em que estrutura o currículo e propõe sua integração, entra em choque com a materialidade das condições de trabalho do IFB e da política que o criou.

Alguns dos professores fizeram considerações finais nas entrevistas e destacamos as falas do professor e representante sindical e do professor e diretor geral de campus:

Olha, eu creio que pode ser uma ideia utópica de pensar um projeto onde a estrutura seja engajada na escola, no Instituto, que é uma escola, não é? Aqui é uma escola. Que tenha de repente as outras modalidades como apêndice, ou como... mas que tipo de educação é essa? Ela é voltada para o mercado? Ela é voltada pra formação de cidadania plena? Ou pelo menos na ideia de cidadania? $E$ eu acho que falta muito ainda debate sobre verticalização aqui dentro, não é? $O$ que seria isso de fato? (Prof. Sindi). 
Eu volto lá para o começo, trabalhar no ensino básico, técnico, tecnológico, licenciatura, mestrado e doutorado, pós-doutorado, apesar de a gente só ter um doutorado no país. Alguns mestrados e muitas especializações. É um sonho, é romântico. A gente pode ir com o tempo se descobrir, se damos conta de ter sonhado realmente algo único no mundo, enquanto experiência de educação profissional, mas extrapola, por que tem as licenciaturas também, ou podemos, com o tempo, reconhecer que sonhamos muito alto, a aposta foi muito alta. $\mathrm{O}$ que não necessariamente, para mim hoje é algo negativo. A gente tem hoje um sonho extremamente ousado, por sonhar ousado, e acreditar no sonho, eu acho que a gente vai, mesmo não atingindo êxito, a gente vai atingir diferentes resultados, mas talvez em algum momento a gente reconheça que não deu para fazer tudo o que foi sonhado e haja necessidade de algum ajuste enquanto Rede. É isso. (Prof. DG).

As considerações finais dos professores em conjunto com as unidades de análise nos fazem pensar na relação escola e sociedade. Concordamos com o professor e representante sindical ao afirmar que o IFB é uma escola. É também escola técnica, é universidade, é polo de educação a distância, é espaço de pesquisa e extensão, espaço educacional, de formação, de conflitos e contradições. Assim como Silveira (1995) acreditamos que a "a escola não pode ser vista apenas como representante dos interesses da classe dominante, uma mera reprodutora da estrutura social. Ela não é o 'feudo da classe dominante'; ao contrário, é 'palco de contradições', campo de batalha onde se confrontam as forças da dominação e as forças da libertação" (p. 21). Contudo, diante dos interesses antagônicos e irreconciliáveis entre capitalistas e trabalhadores, qual o compromisso de classe assumido pelos professores que atuam na educação profissional, técnica e tecnológica no IFB?

O autor faz reflexões pertinentes a respeito do compromisso político do professor, principalmente aqueles que não passaram por nenhum tipo de formação para a docência ou aqueles que estão em início de carreira, ou seja, perfil bastante predominante de docente que temos atualmente no IFB. Esses professores geralmente não realizam reflexões sobre as implicações políticas do seu trabalho. E como o trabalho do professor se insere nessa conjuntura?

A natureza do trabalho docente neste contexto, ou seja, assalariado, classe que vive do trabalho, funcionário do Estado, sujeito à lógica de mercado, de otimização, flexibilização, versatilidade e produtividade, que realiza trabalho imaterial e improdutivo, envolto por múltiplas determinações de contexto histórico, político e 
social no âmbito da verticalização da educação em um Instituto Federal foram características observadas ao longo da pesquisa.

Há uma relativa autonomia no trabalho do professor do IFB em conflito com as exigências externas de avaliação, controle do trabalho com metas impostas na própria lei de criação dos IFs, nos acordos de metas e compromissos, bem como as prestações de contas padronizadas para todo tipo de campus. Assim observamos o controle parcial do processo de trabalho "além do fetichismo da autonomia que permeia a academia e o coletivo de professores." (MIRANDA, op. cit. p. 4). A autonomia do trabalho docente é relativa, nas condições objetivas observadas nas falas dos professores do IFB, entre o planejamento e a execução, o tempo para o planejamento, a intensificação e a autonomia para planejar sem a qualificação necessária para todos os níveis e modalidades na qual atuam. Ainda de acordo com a autora superestimar autonomia do professor oculta as "relações sociais em que este tipo de trabalho está inserido, não pode tornar-se um fetichismo aparentando uma força mística que impede o capital de qualquer forma de subordinação" (Idem, p. 5).

O Instituto Federal pode ser pensado como uma ideia utópica, a qual foi realizada sem o devido debate sobre o que é a verticalização ou para qual cidadania o aluno está sendo formado. Ao mesmo tempo pode também ser um sonho romântico e ousado que precise ser ajustado conforme a realidade objetiva se apresenta no trabalho dos professores. Esse trabalho se desenvolve adquirindo sentidos e significados que "[...] resultam e constituem-se como parte das relações sociais em diferentes épocas históricas e um ponto central da batalha das ideias na luta contra-hegemônica à ideologia e à cultura burguesas.” (FRIGOTTO, 2009, p. 169).

Assim, partindo dos estudos analisados e da coleta de dados com os professores do IFB pudemos nos empreender nas mediações do trabalho docente, buscando apreender as relações concretas e as particularidades da atual política de expansão de educação da classe trabalhadora por meio dos IFs. Desse modo, as unidades de análise contribuíram para a elaboração de algumas conclusões, ainda que provisórias, sobre os elementos constituidores do trabalho docente na verticalização do Instituto Federal de Brasília. Cada unidade de análise expressou os conflitos existentes e as relações contraditórias envolvidas no problema da pesquisa, resultando em pares dialéticos para os quais intencionamos realizar sínteses.

A política de verticalização e integração da educação básica à superior é a categoria que buscou a compreensão do fenômeno, sua relação com os demais 
fenômenos e o movimento das suas mediações. Os elementos do trabalho docente na verticalização apareceram marcados pelas contradições nas suas dualidades e disparidades intimamente ligadas à política, bem como os estruturantes do trabalho docente na verticalização reiteraram os demais elementos apresentados pelos professores do IFB nas unidades de análise anteriores. Dessa forma temos um cenário onde a "educação é uma totalidade de contradições atuais ou superadas, aberta a todas as relações [...] e a ação recíproca entre essas esferas do real se mediam mutuamente através das relações de produção, relações sociais e relações político-ideológicas" (CURY, op. cit. p. 67).

Desse modo, para os professores do IFB a política se mostrou como algo positivo, mesmo que estes se considerem participantes mais em nível local que nacional. A efetividade da política aparece ao promover o acesso à educação profissional e superior, bem como levar o Instituto Federal para localidades onde antes não havia escolas desse tipo. E isso se revelou como um aspecto positivo a oportunidade de os alunos traçarem um itinerário formativo na instituição, podendo seguir com seus estudos. A verticalização apresentou-se como sinônimo de vantagem para o corpo discente, enquanto que para os docentes do IFB a vantagem é ter experiência em várias áreas, níveis e modalidades, contraditoriamente, em mesmo nível essa polivalência por nível de ensino também se anunciou como desvantagem.

A expansão acelerada do IFB, porém, não foi acompanhada na totalidade pela infraestrutura correta para a realização da verticalização. A proposta dos IFs esbarra em suas condições objetivas de execução, ou seja, a estrutura otimizada e nem sempre suficiente e sujeita a rigoroso controle de metas são impasses para a realização da verticalização e integração da educação com um mesmo corpo docente. O limite de professores por campus junto com o orçamento atrelado ao número de alunos matriculados e as metas padronizadas foram apontadas como adversidades para a realização do trabalho.

As dificuldades para a realização da integração da educação básica à superior envolveram principalmente a falta de formação dos docentes para atuação na verticalização junto com o pouco conhecimento sobre as implicações dessa verticalização para o trabalho previamente ao entrar na instituição. Nesse sentido os professores do IFB demonstraram ter mais interesse na formação em suas próprias especialidades e realizarem estudos de pós-graduação em áreas específicas de conhecimentos outros do que a formação pedagógica e didática voltada a cada nível e 
modalidade ofertada pelo IFB. A docência na verticalização parece ser mais uma questão de titulação, flexibilidade e ter experiências prévias. Talvez por essa situação a atuação em apenas um nível tenha sido apontada como a situação ideal de trabalho para parte dos docentes que se sentem sobrecarregados ou sem a devida formação.

É preciso destacar que a necessidade de formação desses docentes choca-se como o tempo disponível para se qualificar, pois diversos professores estão sobrecarregados com tarefas que em muito ultrapassam a docência em sala de aula. E essa formação tem sido vista como uma responsabilidade individual e não como uma demanda coletiva e de responsabilidade institucional.

Assim como a formação é vista como uma iniciativa própria e pessoal, a experiência adquirida pelos professores ao atuar em níveis e modalidades distintas também pareceu ser uma ação individual. O par dialético coletividade-individualidade apareceu atrelado a aspectos que dificultam a integração da educação e a integração docente, tais como a sobrecarga de trabalho, o que nos remete de volta à intensificação. A docência, associada às atividades de gestão, com fortes características burocráticas, pesquisa e extensão contribuem para a intensificação que, entre outros elementos, mostrou-se na extensão da jornada de trabalho dos professores do IFB.

O trabalho fragmentado como dificuldades para a realização da integração da educação básica à superior corroborou o individualismo dos docentes que se destacou sobre as questões que envolvem a coletividade, culminando também na fragilidade do movimento associativo entre os docentes do IFB. Nesse sentido Silveira (op. cit.) afirma a necessidade de engajamento político e sindical dos professores preocupados com a transformação da sociedade, uma vez que "os problemas educacionais não se resolvem definitivamente apenas no âmbito da própria escola" (p. 29).

A totalidade desses elementos constituiu o par dialético satisfação-insatisfação com o trabalho docente e evidenciaram vivências de prazer e sofrimento. Assim, temos uma situação na qual verticalização e sua organização curricular aparecem de forma geral como uma concordância entre os professores do IFB, porém não como a objetividade do trabalho está constituída nesse princípio.

Os pares dialéticos sintetizam o trabalho docente no âmbito da polivalência por nível de ensino em uma instituição concebida em torno da verticalização e integração educacional. São os limites e as possibilidades de integrar e organizar o currículo da educação básica à superior em meio às diversas contradições, uma unidade de contrários que constitui o complexo e dinâmico tecido social. 


\section{CONSIDERAÇÕES FINAIS}

Até os nossos dias, a história de toda a sociedade tem sido a história das lutas de classe.

(MARX; ENGELS, 1998)

A história da educação profissional federal no Brasil percorreu seu caminho desde o ano 1909 quando houve o estabelecimento das Escolas de Aprendizes Artífices até cem anos depois, com a criação da Rede Federal de Educação Profissional, Científica e Tecnológica. Esse percurso foi entremeado por reformas educacionais, transformações políticas, sociais e de reestruturação produtiva do modo de produção capitalista, encadeando assim, modificações na maneira de pensar e realizar as políticas públicas para a educação profissional e tecnológica no país, com consequências para o trabalho docente.

A recente e acelerada expansão da Rede Federal junto com a criação dos Institutos Federais trouxeram implicações para o trabalho dos seus professores e professoras. Os estudos aqui analisados indicaram que os docentes, aqueles que materializam a política pública de ensino da educação profissional, técnica e tecnológica pouco participaram na elaboração e nos processos decisórios de reorganização da EPT. E os novos professores que chegam aos IFs não têm clareza dos objetivos e características da nova instituição. Desse modo, a identidade docente nos IFs é incerta em meio a uma nova institucionalidade ambígua e ainda em construção.

A verticalização é a estrutura curricular e organizacional da nova institucionalidade dos IFs e que integra o currículo e o itinerário formativo do corpo discente da educação básica à educação superior. Os professores que atuam nesse cenário parecem reproduzir a institucionalidade de uma universidade em uma instituição não universitária, mas que promove um hibridismo inédito no campo educacional ao unir educação básica e ensino superior com o mesmo corpo docente, no mesmo espaço físico, ou seja, de maneira a otimizar os recursos. Nesse sentido, a otimização não se ganha forma de um objetivo educacional, mas muito mais de um objetivo administrativo resultante de uma política pública para EPT.

As políticas públicas em educação incidem diretamente na vida dos professores, e a literatura apontou que as reformas educativas concebidas nas instâncias centrais sem ou com pouca participação e discussão fazem com que a elaboração da política fique 
restrita a alguns especialistas. Essa situação pode gerar resistências quando as propostas não consideram as experiências prévias de quem irá levar a política a cabo (LELIS et al., 2009). A formulação das políticas educacionais é campo de disputa e a análise de seus textos muitas vezes apresentam contradições internas.

O documento é fruto de um conjunto de disputas e, por isso, mesmo, é um documento híbrido, com contradições que, para expressar a luta dos setores progressistas envolvidos, precisa ser compreendido nas disputas internas na sociedade, nos estados, nas escolas. Sabemos que a lei não é a realidade, mas a expressão de uma correlação de forças no plano estrutural e conjuntural da sociedade. Ou interpretamos o Decreto como um ganho político e, também, como sinalização de mudanças pelos que não querem se identificar com o status quo, ou será apropriado pelo conservadorismo, pelos interesses definidos pelo mercado. $\mathrm{O}$ avanço na educação mais completa, na formação humana que defendemos para jovens e adultos trabalhadores não se dará apenas pela contestação aos seus elementos de acomodação aos diferentes interesses que se enfrentaram durante sua elaboração e que continuam ativos na sua possível implementação. Há que se dar historicidade ao debate e à ação. A história nos coloca num terreno contraditório da dialética de velho e do novo de lutarmos contra a ideologia e democracia burguesas, no espaço restrito desta democracia burguesa em que vivemos (FRIGOTTO, 2005, p. 4).

Nesse sentido, a proposta dos IFs apresenta sinalizações de mudanças e contradições uma vez que é marcada pelo discurso da ampliação e consolidação da educação profissional como lócus de formação da classe trabalhadora e ao pretender conciliar interesses de classes antagônicas e emancipar o homem à condição de cidadão por meio do desenvolvimento socioeconômico e da "criação de oportunidades, para a redistribuição dos benefícios sociais, visando à diminuição das desigualdades." (BRASIL, 2010) e não para a sua superação.

As Concepções e Diretrizes dos IFs (2008) propõem a “inclusão social emancipatória" (p. 14) como diferencial da RFEPCT e que ela seja contrária a "centralidade do mercado, a hegemonia do desenvolvimento industrial e um caráter pragmático e circunstancial para a educação profissional e tecnológica.” (p.23). O IFB em seu Estatuto (2009) afirma que a sua finalidade é de formar "cidadãos com vistas à atuação profissional nos diversos setores da economia", orientando sua oferta "formativa em benefício da consolidação e fortalecimento dos arranjos produtivos locais" (p. 5). Os IFs visam, conforme a sua lei de criação [...] à emancipação do cidadão na perspectiva do desenvolvimento socioeconômico [...] (BRASIL, 2008, Art. 7) um enunciado educativo de sustentação da produção capitalista, com todas as suas 
implicações e contradições tanto em relação ao trabalho docente, quanto à relação educação e trabalho.

Tomar o trabalho como princípio educativo e, no caso dos IFs "como categoria orientadora das políticas da educação profissional e tecnológica” (BRASIL, 2010, p. 33) vem se constituindo "como fundamento de propostas de educação que se pretendem inovadoras e progressistas" (TUMOLO, 2005, p. 240). O trabalho, no âmbito da política educacional dos IFs se confunde com emprego, assim como a emancipação se confunde com cidadania. A ilusão sobre "a possibilidade de construir uma educação geral, omnilateral ou politécnica dentro do sistema capitalista." Frigotto (2009, p.171) assim como o trabalho como princípio educativo é impensável sob a lógica do capital por ser alienante, ou seja, um lema sem consistência teórica ou, como afirma Ciavatta (2009) se o trabalho pode ser alienante e embrutecedor, como pode ser princípio educativo, humanizador, de formação humana?

É na dialética entre totalidade e contradição (CURY, 1987) da política que situamos o trabalho docente no IFB, uma instituição que não necessariamente oferece formação adequada aos seus quadros de professores, em um processo de verticalização, que agrega níveis e modalidades diferentes em uma mesma instituição o que tem promovido a intensificação do trabalho docente. Trata-se de um trabalho que vem sendo marcado pela complexificação, não só pela sobrecarga de tempo, mas

[...] também da ampliação e diversificação das tarefas que os professores são chamados a desempenhar, seja pelas mudanças na composição social do público escolar, seja pela implementação de políticas educacionais com visíveis impactos no cotidiano do trabalho em sala de aula (LELIS et al., 2009, p. 113).

Os estudos sobre os IFs apontaram para a docência direcionada ao atendimento das diferentes áreas tanto de conhecimento como de níveis, fragilizando a compreensão sobre a materialidade do trabalho e salientando elementos de sua intensificação. $O$ trabalho dos professores nos IFs se caracteriza pela sua diversificação, uma vez que ser professor não é apenas estar em sala de aula, mas também o envolvimento com a gestão do espaço escolar, a participação em reuniões internas, reuniões externas com a comunidade, por exemplo, reunião com os pais dos alunos da educação básica. Ao mesmo tempo em que o professor do Instituto Federal tem as atribuições e responsabilidades de um professor de ensino médio e de nível superior, ele também deve se dedicar no seu cotidiano à realização de pesquisa aplicada e ações de extensão, 
visando, conforme a legislação, o desenvolvimento dos arranjos produtivos locais. Some-se a isso o tempo dedicado à preparação das aulas, correção de provas, elaboração de exercícios, preenchimento dos múltiplos diários de classe e escrita de relatórios para prestar conta de todas as suas atividades.

As condições concretas de trabalho em cada Instituto Federal são desiguais, conforme sua historicidade e oferta de educação profissional e superior, portanto importa se foi criado a partir de um CEFET ou colégio agrícola, interessa se trata de um campus centenário ou recém-criado, se funciona de maneira adequada ou improvisada, quais as condições dos professores realizarem o ensino, a extensão, a pesquisa ou mesmo seus estudos de pós-graduação, tão necessários ao desenvolvimento profissional. Podemos perceber no IFB uma "diversidade das condições de exercício da profissão" (LELIS et al, 2009, p. 114) com campi em condições materiais mais ou menos compatíveis às exigências que são gerais para todos.

A criação dos Institutos Federais aparenta ser uma inovação no campo educacional, porém, até aqui os IFs estão se desvelando como a junção de antigos modelos educacionais, tanto em nível médio quanto em nível superior, sem apresentar modificação enquanto processo educativo, apesar do discurso inovador. A novidade está na expansão e acesso à educação profissional de nível médio e superior em localidades onde antes não havia e para populações historicamente marginalizadas e, ao mesmo tempo, na criação de uma única instituição pluricurricular, verticalizada, com estrutura otimizada que sobrecarga parte de seus docentes.

Por entendermos que "[...] não é possível apreender o significado de uma política educacional sem a apreensão da lógica global de um determinado sistema de produção" (MASSON, 2012, p. 8) compreendemos que os IFs se situam de maneira muito adequada na lógica do capital em sua forma neoliberal, atendendo a uma legislação educacional alinhada ao pensamento da flexibilização e otimização de recursos na qual é possível fazer mais com menos. As tensões das contradições no cerne da totalidade manifestam-se numa única instituição e seu corpo técnico e docente ficam responsáveis por dar conta da demanda de formação de professores em cursos de licenciaturas, de graduação tecnológica, de oferecer ensino médio profissional, EaD e cursos de qualificação rápida.

Nesse contexto, o professor é visto como trabalhador polivalente, multifuncional, que tem sua produtividade aumentada a partir de metas estabelecidas externamente. Professores que enfrentam ao mesmo tempo as situações e os problemas 
do magistério superior e a docência na educação básica, lidam com uma diversidade de público e alunos provenientes da classe trabalhadora que vão de adolescentes a adultos, idosos; pessoas em situação de vulnerabilidade social e portadores de necessidades especiais em uma estrutura escolar enxuta.

O perfil do Instituto Federal, mesmo oferecendo nível superior é bastante diferente de uma universidade federal. Da mesma forma, o perfil do professor que trabalha no IFB se mostrou variado sendo composto, entre outros, por bacharéis docentes, ou seja, professores aprovados em concursos públicos, os quais exigem em seus editais apenas o diploma de graduação (SOUZA; NASCIMENTO, 2013). A situação que encontramos nos IFB é de descumprimento da própria legislação educacional, visto que a LDB em seu Artigo $n^{\circ} 65$ exige que os professores da Educação Básica tenham formação em cursos de licenciatura. A exceção é para a docência em cursos de em nível superior, para o qual se exige que o professor deve ser titulado em cursos de pós-graduação, preferencialmente stricto sensu.

Assim, em alguns casos o Instituto Federal de Brasília atua distante da legislação educacional, pois seleciona professores bacharéis para lecionar na educação básica e graduados para lecionar no ensino superior sem oferecer um programa de formação para estes docentes. Mesmo os professores licenciados e que tiveram uma formação para atuação na educação básica, seja no ensino da Física, Arte, Música, “[...] o que é diferente de atuar, mesmo nessas disciplinas, em cursos cujo fim é a formação profissional." (MOURA, 2008, p. 32) aprendem na prática como integrar ensino propedêutico com ensino profissional.

Os próprios editais de seleção para professores, tanto no IFB como nos demais IFs não exigem, mas apreciam na forma de pontuação a titulação acadêmica dos candidatos à docência, valorizando "as experiências do candidato como pesquisador (especialista, mestre ou doutor)" (SOUZA; NASCIMENTO op. cit., p. 416), sem, necessariamente, exigir experiência profissional na área onde irá atuar. Os professores dos IFs, bacharéis e licenciados, são selecionados a partir da lógica da contratação de professores do ensino superior, mas encaram também a realidade de docentes do ensino básico, técnico e tecnológico.

As pesquisas analisadas indicam os CEFETs como as instituições com as condições propícias para a criação dos IFs porque já realizavam a verticalização. As condições concretas também estavam presentes pelos CEFETs terem a infraestrutura adequada aos cursos técnicos oferecidos e que seriam aproveitados nos cursos 
superiores, uma vez que o quadro de professores dessas instituições, em sua maioria, era composto por titulados e que já haviam passado por cursos técnicos em sua formação em alguns casos até ex-alunos - e que tinham experiência profissional na área técnica, por isso poderiam atuar na verticalização.

$\mathrm{Na}$ análise da fala dos professores e professoras do IFB percebemos os pares dialéticos e as marcas da ambiguidade do trabalho docente na verticalização. A correlação desses pares com as políticas públicas de educação levaram a um cenário de uma instituição nova que não necessariamente oferece infraestrutura correta para a realização da verticalização e integração educacional conforme foi proposta.

A não formação docente apareceu marcadamente como um dos elementos que dificultam a integração da educação básica à superior. São professores que têm uma formação, mas não necessariamente está adequada à sua atuação no IFB. Ao mesmo tempo, a polivalência por nível de ensino é percebida como vantagem e desvantagem para o corpo docente do IFB, que pouco se percebe em um coletivo de trabalhadores da educação, formando o par coletividade-individualidade. Trata-se de outro aspecto que embaraça a integração educacional e a integração docente.

A fragmentação do trabalho docente cria empecilhos para a realização da integração da educação básica à superior, ratifica o individualismo e desencoraja o movimento associativo entre os professores. Ao mesmo tempo, a fragmentação é também resultado da intensificação do trabalho docente, uma vez que a sobrecarga ecoa no sentido do trabalho e no estabelecimento da identidade do professor enquanto uma coletividade.

Por fim, a satisfação-insatisfação trazida pelo trabalho docente no Instituto Federal de Brasília desvelou o princípio da verticalização, em sua maior parte, apoiado pelos docentes do IFB, mas não como está posto na materialidade da constituição dessa premissa.

Destacamos a importância do olhar sobre o impacto da verticalização no trabalho dos professores e a pertinência ao abordar questões, como por exemplo: as condições materiais de trabalho, as exigências sobre as atividades que devem ser desenvolvidas, as inquietações e os desafios trazidos pelas várias ocupações, as experiências dos professores e a organização pedagógica como um todo. Os professores são chamados a desempenhar funções e responder a exigências que muitas vezes estão além da sua formação. É preciso um "conjunto de condições de trabalho para uma prática que se quer competente" (LELIS et al., op. cit., p. 123). Esses são aspectos que 
denotam a materialidade do trabalho que expressam também os nexos entre este trabalho e as demandas oficiais das políticas públicas que lhes são impostas afetando a sua autonomia e promovendo intensificação.

O processo de intensificação do trabalho docente deve ser compreendido no âmbito das transformações do mundo do trabalho e de uma reflexão crítica sobre qual a função social do Instituto Federal. Sendo o capital "a potência econômica da sociedade burguesa, que domina tudo" (MARX, 1982, p. 19) e a sociedade burguesa "a organização histórica mais desenvolvida, mais diferenciada da produção" (Idem, p. 17) temos uma situação na qual "cada sociedade, em cada modo de produção e regimes de acumulação, dispõe de formas próprias de educação que correspondem às demandas de cada grupo e das funções que lhes cabe desempenhar na divisão social e técnica do trabalho.” (KUENZER; GRABOWSKI, 2006, p. 300).

O mérito da instituição da RFEPCT está em unificar a política e a oferta de educação profissional, mas a proposta dos IFs não convenceu a todos por suas limitações e amarras previstas na legislação. Aqueles que puderam optar decidiram não migrar para o novo formato. De qualquer forma, parece que é esse o movimento do real. Temos de, a partir das condições disponíveis, encontrar os caminhos para a superação dos limites do existente (SAVIANI, 2003, p. 132).

Dessa forma, os pares dialéticos sintetizados em cada unidade de análise nos trazem os elementos da política que é percebida como positiva, desconhecida e contraditória para os professores. Os elementos do trabalho docente na verticalização envolvem a intensificação, a satisfação e a insatisfação e as disparidades na carga horária, na formação e na remuneração, assim como os estruturantes do trabalho docente na verticalização aparecem relacionados com os eixos de formação docente, integração e verticalização e as condições de trabalho. São pares que reforçam que tanto a ambiguidade como a clareza de um projeto político-pedagógico para a docência a ser exercida são elementos característicos da marca da polivalência no trabalho docente realizado tal como o é o trabalho do professor no contexto da verticalização.

Assim, temos uma educação possível em um cenário desfavorável, principalmente no momento atual de crise e golpe contra a democracia. Reafiramos o caráter provisório dessas conclusões, situadas em um momento histórico determinado em uma perspectiva de produção do trabalho docente que atua no processo de formação humana e na possibilidade de outra educação para os que vivem do trabalho. 


\section{REFERÊNCIAS}

ADVOCACIA-GERAL DA UNIÃO. AGU, Procuradoria-Geral Federal, Procuradoria Federal junto ao IFB. Parecer no 00247/2015/VO/PFIFBRASÍLIA/PGF/AGU sobre a Minuta de Resolução, 2015.

AGUIAR, Wanda Maria Junqueira de; OZELLA, Sérgio. Apreensão dos sentidos: aprimorando a proposta dos núcleos de significação. R. bras. Est. pedag., Brasília, v. 94, n. 236, p. 299-322, jan./abr. 2013.

APPLE, M.W. Trabalho docente e textos: economia política das relações de classe e de gênero na educação. Porto Alegre: Artes Médicas, 1995.

ALVES, Thiago; PINTO, José Marcelino de Rezende. REMUNERAÇÃO E CARACTERÍSTICAS DO TRABALHO DOCENTE NO BRASIL: UM APORTE. CADERNOS DE PESQUISA, N.143 MAIO/AGO. 2011.

AMORIM, Henrique. As teorias do trabalho imaterial: uma reflexão crítica a partir de Marx. Caderno CRH. Vol.27 nº. 70. Salvador Jan./Apr. 2014.

ANTONIAZZI, Maria Regina Filgueiras. A educação profissional no contexto da sociedade capitalista brasileira: análise a partir do método crítico-dialético. Revista Entreideias, Salvador, v. 1, n. 2, p 127-145, jul/dez. 2012.

ANTUNES, Ricardo. Os sentidos do trabalho: ensaio sobre a afirmação e negação do trabalho. São Paulo: Boitempo. 1999.

ARAUJO, Jair Jonko. A complexa construção de sentidos no cotidiano escolar: o caso da área de design do campus Pelotas do Instituto Federal Sul-rio-grandense. Currículo sem Fronteiras, v. 14, n. 3, p. 208-229, set/dez 2014.

ARRUDA, Maria da Conceição Calmon; PAULA, Lucília Augusta Lino de. Os Institutos Federais como instituição formadora de professores: expectativas e contradições. In: Universidade Federal Rural do Rio de Janeiro XVI ENDIPE Encontro Nacional de Didática e Práticas de Ensino - UNICAMP - Campinas - 2012.

BASSO, Itacy Salgado. Significado e sentido do trabalho docente. Caderno CEDES vol. 19 n. 44 Campinas. Abr. 1998.

BATISTA, Eraldo Leme. Trabalho e educação profissional nas décadas de 1930 e 1940 no Brasil. Campinas - SP: Autores Associados, 2015.

BRASIL. Crêa nas capitaes dos Estados da Republica Escolas de Aprendizes Artifices, para o ensino profissional primario e gratuito. Diário Oficial da União Seção 1 - 26/9/1909, Página 6975. Decreto nº 7.566, de 23 de Setembro de 1909.

Constituição dos Estados Unidos do Brasil. Presidência da República. Casa Civil. Subchefia para Assuntos Jurídicos. De 10 de novembro de 1937.

Regulamento da Lei orgânica do ensino industrial. Decreto-Lei $n^{\circ}$ 4073 de 30 de janeiro de 1942.

. Proposta em discussão: políticas públicas para a educação profissional e tecnológica. Brasília: MEC/Setec. 2004. 
. Ensino Médio Integrado à Educação Profissional. MEC, Brasília: Boletim 07, maio/jun. 2006.

Educação profissional técnica de nível médio integrada ao ensino médio. Documento base. Brasília: MEC/Setec. 2007.

O PLANO DE DESENVOLVIMENTO DA EDUCAÇÃO RAZÕES, PRINCÍPIOS E PROGRAMAS. Brasília: MEC, $2007 \mathrm{~b}$.

Institui a Rede Federal de Educação Profissional Científica e Tecnológica e dá outras providências. Congresso Nacional. Lei 11.892, de 29 de dezembro de 2008.

. Concepção e diretrizes - Instituto Federal de Educação, Ciência e Tecnologia. Brasília: MEC/Setec. 2008b.

- Planejando a Próxima Década Conhecendo as 20 Metas do Plano Nacional de Educação. Presidência da República - Ministério da Educação - Secretaria de Articulação com os Sistemas de Ensino, 2014.

BARBETTA, Pedro Alberto. Estatística aplicada às ciências sociais. $5^{\mathrm{a}}$ edição revisada. Florianópolis - Editora da UFSC, 2002.

BRESSER-PEREIRA, Luiz Carlos. Empresários, o governo do PT e o desenvolvimentismo. Revista de Sociologia e Política. V. 21, No 47: 21-29 Set. 2013.

BREZINSKI, Iria. Estado do conhecimento sobre formação de profissionais da educação: teses e dissertações do período 2003-2010. Indagatio Didactica, vol. 5(2), outubro. Universidade de Aveiro. 2013.

CAMPOS, Claudinei José Gomes; TURATO, Egberto Ribeiro. Análise de conteúdo em pesquisas que utilizam a metodologia clínico-qualitativa: aplicação e perspectivas. Rev Latino-am Enfermagem, março-abril; 17(2), 2009.

CIAVATTA, Maria. Trabalho como Princípio Educativo. Dicionário da Educação Profissional em Saúde. Fundação Oswaldo Cruz. Escola Politécnica de Saúde Joaquim Venâncio. 2009

CODO, Wanderley (Coord.). Educação: carinho e trabalho. $4^{\mathrm{a}}$ Ed. Petrópolis-RJ: Vozes. 2006.

CONTROLADORIA GERAL DA UNIÃO - CGU. Relatório de auditoria n'201405747. 2014.

CUNHA, M.I. Profissionalização docente: contradições e perspectivas. In: VEIGA, I.P.A.; CUNHA, M.I. (Org.). Desmistificando a profissão do magistério. Campinas: Papirus, 1999. p.127-147.

CRUZ, Shirleide Pereira da Silva. A CONSTRUÇÃO DA PROFISSIONALIDADE POLIVALENTE NA DOCENCIA NOS ANOS INICIAIS DO ENSINO FUNDAMENTAL: sentidos atribuídos às práticas por professoras da Rede Municipal de Ensino do Recife. Tese de doutorado, UFPE, 2012.

CRUZ, Shirleide Pereira da Silva; NETO, José Batista. A polivalência no contexto da docência nos anos iniciais da escolarização básica: refletindo sobre experiências de pesquisas. Revista Brasileira de Educação. V. 17, nº 50. Maio-ago. 2012. 
CRUZ, Shirleide Pereira da Silva; VITAL, T. R. S. A construção da profissionalidade docente para a educação profissional: análise de concursos públicos para docente. HOLOS, Ano 30, Vol. 02, 2014.

CONCEFET. Manifestação do CONCEFET sobre os Institutos Federais de Educação Ciência e Tecnologia. Brasília, 23 de agosto de 2007.

CUNHA, Luiz Antonio. O ensino industrial-manufatureiro no Brasil. In: Revista Brasileira de Educação. Mai/Jun/Jul/Ago, N 14, 2000.

CURADO-SILVA, Kátia Augusta Pinheiro Cordeiro. Professores com formação strico sensu e o desenvolvimento da pesquisa na educação básica da rede pública de Goiânia: realidade, entraves e possibilidades. Tese de Doutorado. Goiânia, UFG PPGE, 2008.

DAL ROSSO, Sadi. Mais trabalho! A intensificação do labor na sociedade contemporânea. São Paulo: Boitempo, 2008.

Teoria do valor e trabalho produtivo no setor de serviços. Caderno CRH, Salvador, v. 27, n. 70, p. 75-89, jan./Abr. 2014.

DIAS, Adriano; MELO, Lucia; TÁVORA, Luciana; KELNER, Sergio. Impulsionando a Inovação: à consolidação da rede que conhece o nosso chão, os Institutos Federais de Educação, Ciência e Tecnologia. Recife: Fundação Joaquim Nabuco, janeiro 2016.

DISTRITO FEDERAL. Síntese de Informações Socioeconômicas. Companhia de Planejamento do Distrito Federal (Codeplan). Brasília: Codeplan, 2014.

FARIAS, Itamar Mazza de. Diferenças entre polivalência e politecnia: implicações para a formação da concepção sobre o trabalho no processo educativo. Educação e Filosofia, 12 (33) 11-29, jan./jul. 1998.

FARTES, Vera Lúcia Bueno. Reforma da educação profissional e crise das identidades pedagógicas e institucionais. Cadernos de Pesquisa, v. 38, n. 135, p. 657684, set./dez. 2008.

FERNANDES, Maria Regina da Silva. O processo de verticalização da educação profissional e tecnológica e suas implicações na qualidade do trabalho dos docentes do Câmpus São Vicente do Sul do Instituto Federal Farroupilha. Dissertação (mestrado) - Universidade Federal Rural do Rio de Janeiro, Curso de Pós-Graduação em Educação Agrícola. UFRRJ, Seropédica - RJ, 2013.

FERRETTI, Celso João. Problemas institucionais e pedagógicos na implantação da reforma curricular da educação profissional e técnica de nível médio no IFSP. Educ. Soc., Campinas, v. 32, n. 116, p. 789-806, jul.-set. 2011.

FIDALGO, Nara L. Rocha; FIDALGO, Fernando. Trabalho docente e a lógica produtivista: conformações e subjetividade. In FIDALGO, Fernando; OLIVEIRA, Maria Auxiliadora M. e FIDALGO, Nara L. Rocha. A intensificação do trabalho docente tecnologias e produtividade. Campinas - SP: Papirus, 2009.

FRANCO, Maria Laura P. B. Análise de conteúdo. Brasília, $4^{\mathrm{a}}$ edição: Líber Livro, 2012.

FREIRE, Eleta de Carvalho. MULHER NO MAGISTÉRIO: UMA HISTÓRIA DE EMBATES ENTRE ESPAÇO PÚBLICO E ESPAÇO PRIVADO. Revista Lugares de Educação, Bananeiras/PB, v. 1, n. 2, p. 239-256, jul.-dez. 
FRIGOTTO, Gaudêncio. O enfoque da dialética materialista histórica na pesquisa educacional. In: FAZENDA, Ivani (Org.) Metodologia da Pesquisa Educacional. São Paulo: Cortez, 1999.

. Trabalho. In: Dicionário da Educação Profissional em Saúde. Fundação Oswaldo Cruz. Escola Politécnica de Saúde Joaquim Venâncio. 2009.

. A dupla face do trabalho: criação e destruição da vida. In: FRIGOTTO, Gaudêncio; CIAVATTA, Maria (Org.). A experiência do trabalho e a Educação Básica.

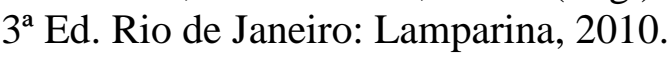

A polissemia da categoria trabalho e a batalha das ideias nas sociedades de classe. Revista Brasileira de Educação v. 14 n. 40 jan./abr. 2009.

GAMBOA, Silvio Sanchez. Fundamentos para la investigacion: pressupuestos epistemológicos que orientan al investigador. Editorial Magistério, Bogotá, 1998.

Argos. 2012.

Pesquisa Em Educação: métodos e epistemologias. Chapecó-SC: Editora

GATTI, Bernadete Angelina; BARRETO, Elba Siqueira de Sá (Coord). Professores do Brasil: impasses e desafios - Brasília: UNESCO, 2009.

GESTRADO. Pesquisa trabalho docente na educação básica no Brasil: sinopse do survey nacional/Universidade Federal de Minas Gerais, Grupo de Estudos Sobre Política Educacional e Trabalho Docente. Belo Horizonte, 2010.

GERHARDT, Tatiana Engel; SILVEIRA, Denise Tolfo (Org.). Métodos de Pesquisa. Série Educação a Distância. SEAD/UFRGS. - Porto Alegre: Editora da UFRGS, 2009.

GONÇALVES, Sandra Lúcia. A expansão da rede de educação profissional, científica e tecnológica: implicações nas relações e condições de trabalho no Instituto Federal de Educação, Ciência e Tecnologia de Goiás/ Sandra Lúcia Gonçalves. Goiânia, 2014.

GONTIJO, Simone Braz Ferreira. Interfaces entre a formação do professor da educação superior e a formação de professores da educação básica. In: SILVA, Kátia Augusta Curado Pinheiro Cordeiro da; LIMONTA, Sandra Valéria (Orgs.). Formação de Professores na perspectiva crítica: resistência e utopia. Brasília: Editora UnB, 2014.

HIRO, Cássio Diniz. Educação, trabalho e proletarização: o professor enquanto trabalhador docente. Revista Espaço Acadêmico, no 144, mai. 2013.

HYPÓLITO, A.M. Trabalho docente e profissionalização: sonho prometido ou sonho negado? In: VEIGA, I.P.A.; CUNHA, M.I. (Org.) Desmistificando a profissionalização do magistério. Campinas: Papirus, 1999. p.81-100.

HOBSBAWN, Eric. Sobre a história. São Paulo: Companhia das Letras, 1993.

IFB. RESOLUÇÃO N. ${ }^{\circ}$ 24/2009 - RIFB. Estabelece a distribuição da carga horária didática semanal dos docentes do IFB por tipo de atividade e dá outras providências.

Plano de Desenvolvimento Institucional 2014-2018. Ministério da Educação, Secretaria de Educação Profissional e Tecnológica. Brasília-DF, abr. 2014.

Análise das Contribuições da Comunidade [Comissão para reavaliação da Resolução RIFB nº. 24/2009, nomeada pela portaria n. 1959/2015], 2015. 
INEP, Instituto Nacional de Estudos e Pesquisas Educacionais Anísio Teixeira. Censo do Professor. Brasília, 2007.

IOP, Jozeane. Dinâmicas e movimentos da expansão da educação superior: presença da pós-graduação (stricto-sensu) no sudoeste do Paraná. Dissertação (Mestrado) - Universidade Tecnológica Federal do Paraná. Programa de Pós-Graduação em Desenvolvimento Regional. Pato Branco / PR, 2014.

KOSIK, Karel. Dialética do concreto. $7^{\text {a }}$ ed. Rio de Janeiro: Paz e Terra, 2002.

KUENZER, Acácia Z. Exclusão includente e inclusão excludente: a nova forma de dualidade estrutural que objetiva as novas relações entre educação e trabalho. In: SAVIANI, D.; SANFELICE, J.L.; LOMBARDI, J.C. (Org.). Capitalismo, trabalho e educação. $3^{\text {a }}$ Ed. Campinas: Autores Associados, 2005.

SHIROMA, Eneida Oto; SANTOS, Fabiano Antônio dos. In EVANGELISTA, Olinda. (Org.). O que revelam os slogans na política educacional. Araraquara: Junqueira \& Marin Editores, 2014.

SOUZA, Antônio Lisboa Leitão de. Formação inicial e continuada de professores para a educação profissional: a política e a produção do conhecimento para a emancipação. In: Produção de conhecimentos, políticas públicas e formação docente em educação profissional. MOURA, Dante Henrique (Org.) Campinas, SP: Mercado de Letras, 2013.

KUENZER, Acácia Z., CALDAS, Andrea. Trabalho docente: comprometimento e desistência. FIDALGO, Fernando; OLIVEIRA, Maria Auxiliadora M. e FIDALGO, Nara L. Rocha. (Org.). A intensificação do trabalho docente tecnologias e produtividade. Campinas - SP: Papirus, 2009.

LELIS, Isabel; IÓRIO, Ângela C. Fortes; MESQUITA, Silvana S. Araújo; NASCIMENTO, Maria das Graças A. O trabalho docente: a tensão entre intensificação e bem-estar profissional. In: LELIS, Isabel; NASCIMENTO, Maria das Graças (Org.). O trabalho docente no Século XXI quais perspectivas? Rio de Janeiro: Forma \& Ação, 2009.

LESSA, Sérgio. A ontologia de Lukács. Maceió: EDUFAL, 1996.

LIMA, Kátia Regina de Souza. Organismos internacionais e política de educação superior na periferia do capitalismo. In: $26^{a}$ Reunião Anual da Anped, GT: Política de Educação Superior n.11. 2003.

LIMA, Marcio Javam Camelo. Neoliberalismo e Educação. In. Studia Diversa, CCAEUFPB, Vol. 1, No. 1 - Outubro 2007.

LIMA, Antonio Bosco de. Plano decenal de educação para todos e LDB: tudo a ver. In: HISTEDBR, Faculdade de Educação. UFU/MG GT-2: História das Políticas Educacionais no Brasil, 2008.

LIMA, Fernanda Bartoly Golçalves de. A discussão sobre a formação de professores nos Institutos Federais de Educação, Ciência e Tecnologia. In: SILVA, Kátia Augusta Curado Pinheiro Cordeiro da; LIMONTA, Sandra Valéria (Orgs.). Formação de Professores na perspectiva crítica: resistência e utopia. Brasília: Editora UnB, 2014. LIMONTA, S. V. CURADO SILVA, K. A.P.C. Formação de professores, trabalho docente e qualidade de ensino. In: LIBÂNEO, J. C. SUANNO, M. V. R. LIMONTA, S.V. (orgs) Qualidade da escola pública: políticas educacionais, didática e formação de professores. Goiânia: Ceped Publicações; Gráfica e Editora América: Kelps, 2013. 
LOPES, Ediane Carolina Peixoto Marques; CAPRIO, Marina. As influências do modelo neoliberal na educação. Unesp. Departamento de Ciências da Educação. Revista Eletrônica. 2013.

MANCEBO, Deise; SILVA JÚNIOR, João dos Reis. Expansão da educação superior e a reforma da rede federal de educação profissional. Revista Educação em Questão, Natal, v. 51, n. 37, p. 73-94, jan./abr. 2015.

MAGUIRE, Meg; BALL, Stephen J. Discursos da reforma educacional no Reino Unido e nos Estados Unidos e o trabalho dos professores. In: Políticas educacionais: questões e dilemas. BALL; MAINARDES (Orgs). São Paulo: Cortez, 2011.

MARINHO, Ricardo José de Azevedo; COSTA, Pedro Luiz de Araujo. Institutos Federais de Educação, Ciência e Tecnologia: educação profissional e tecnológica brasileira reinstitucionalizada. Anais do II Colóquio Nacional A Produção do Conhecimento em Educação Profissional. Natal: IFRN, 2013.

MARX, Karl. Para a crítica da Economia Política. São Paulo: Abril Cultural, 1982.

Teorias da mais valia. Livro 4 / Volume 1. São Paulo: Bertrand Brasil, 1987.

O processo de trabalho ou o processo de produção de valores de uso. In: O Capital (Vol. I, Parte III: A produção de mais valia absoluta, Cap. V: Processo de trabalho e processo de produção de mais valia). Rio de Janeiro: Bertrand Brasil. 12a Ed. 1989.

MARX, Karl; ENGELS, Friedrich. Manifesto Comunista. São Paulo, Boitempo, 1998.

MASSON, Gisele. As contribuições do método materialista histórico e dialético para a pesquisa sobre políticas educacionais. In: IX ANPED Sul: Seminário de pesquisa em educação da Região Sul. 2012.

MELO, Nildo Aparecido de. Reestruturação capitalista e a base produtiva de presidente prudente: Fordismo/Taylorismo e acumulação flexível e as relações com a empregabilidade dos trabalhadores. Geografia em Atos, n. 8, v.2. UNESP, Presidente Prudente, 2008.

MELO, S.D.G. Trabalho docente na educação profissional. In: OLIVEIRA, D.A.; DUARTE, A.M.C.; VIEIRA, L.M.F. DICIONÁRIO: trabalho, profissão e condição docente. Belo Horizonte: UFMG/Faculdade de Educação, 2010.

MENDES, Luciano; CHAVES, Carlos Jaelso Albanese; SANTOS, Maria Cecília dos;

NETO, Gustavo Adolfo Ramos Mello. A Dialética Prazer/Desprazer no Trabalho: Vivências de Significado e Sofrimento no Trabalho de Professor Universitário. $30^{\circ}$ encontro da ANPAD, Salvador - BA, 2006.

MIRANDA, Kênia. O processo de trabalho docente: interfaces entre a produção e a escola. Boletim Técnico do SENAC, Rio de Janeiro, V. 32, N. 2, maio/ago., 2006.

MINAYO, Maria Cecilia de S.; SANCHES, Odécio. Quantitativo-Qualitativo: Oposição ou Complementaridade? Cad. Saúde Públ., Rio de Janeiro, 9 (3): 239-262, jul/set, 1993.

MENEZES, Graziela Ninck Dias. O trabalho docente na educação profissional técnica. In: 37 Reunião Nacional da ANPEd, UFSC - Florianópolis. 04 a 08 de outubro de 2015. 
MOURA, Dante Henrique. Revista Brasileira da Educação Profissional e Tecnológica. Brasília, Ministério da Educação, Secretaria de Educação Profissional e Tecnológica, 2008.

NETTO, José Paulo. Introdução ao estudo do método de Marx. São Paulo: Expressão Popular, 2011.

NEVES, Lúcia, Maria Wanderley. Por que dois planos nacionais de educação? In: NEVES, L. M. (Org.). Educação e política no limiar do século XXI. Campinas: Autores Associados, 2000.

NOGUEIRA, Ana Lúcia Horta. Concepções de "trabalho docente": as condições concretas e os discursos das prescrições oficiais. Educ. Soc., Campinas, v. 33, n. 121, p. 1237-1254, out.-dez. 2012

NÓVOA, Antônio. Os professores na virada do milênio: do excesso dos discursos à pobreza das práticas. Repositório da Universidade de Lisboa. Maio de 1999.

OLIVEIRA, Dalila Andrade. A reestruturação do trabalho docente: precarização e flexibilização. Educ. Soc., Campinas, vol. 25, n. 89, p. 1127-1144, Set./Dez. 2004.

OLIVEIRA, João Ferreira; MORAIS, Karine Nunes de, DOURADO; Luiz Fernandes. Organização da educação escolar no Brasil na perspectiva da gestão democrática: sistemas de ensino, órgãos deliberativos e executivos, regime de colaboração, programas, projetos e ações. Programa Nacional Escola de Gestores da Educação Básica. MEC/SEB, 2005.

ORTIGARA, Claudino. Institutos Federais: uma nova concepção de educação ou reorganização administrativa? In: Anais do II Colóquio Nacional - A Produção do Conhecimento em Educação Profissional. Natal: IFRN, 2013.

OTRANTO, C. R. Criação e implantação dos Institutos Federais de Educação, Ciência e Tecnologia - IFETs. Publicado pela Revista RETTA (PPGEA/UFRRJ), Ano I, nº 1, jan-jun. p. 89-110. 2010.

PACHECO, Eliezer Moreira; PEREIRA, Luiz Augusto Caldas; SOBRINHO, Moisés Domingos. Institutos Federais de Educação, Ciência e Tecnologia: Limites e possibilidades. Linhas Críticas, Brasília, DF, v. 16, n. 30, p. 71-88, jan./jun. 2010.

PACHECO, Eliezer Moreira (Org.). Institutos Federais: uma revolução na educação profissional e tecnológica. Fundação Santilana, Ed. Moderna. São Paulo, 2011.

QUEIROGA, A. L. F.; SILVA, R. F. Da integração desejada às práticas pedagógicas fragmentadas. Revista Brasileira da Educação Profissional Tecnológica. N. 7, Vol. 1, 2014.

RAMOS, Elbo Lacerda. Consensos e dissensos em torno da alteração do centro de atuação das instituições da Rede Federal de Educação Profissional, Científica e Tecnológica de origem agrícola: representações do trabalho docente. 2011. Tese (doutorado) - Universidade Federal de Uberlândia, Programa de Pós-Graduação em Educação. UFU, MG. 2011.

RÊSES, Erlando Silva. Singularidade da profissão de professor e proletarização do trabalho docente na Educação Básica. SER Social, Brasília, v. 14, n. 31, p. 419-452, jul./dez. 2012.

ROLDÃO, Maria do Céu. Função docente: natureza e construção do conhecimento profissional Revista Brasileira de Educação v. 12 n. 34 jan./abr. 2007. 
RUFINO NETO, Joaquim. A missão institucional do campus Crato do IFCE: percepção da comunidade escolar sobre os avanços e desafios para desenvolver o ensino, a pesquisa e a extensão em um novo projeto de sociedade. Dissertação (Mestrado) - Programa de Pós-Graduação em Educação Agrícola. UFRRJ, Seropédica $-\mathrm{RJ}, 2012$.

RUMMERT, Sonia Maria. Educar e qualificar: caminhos e descaminhos da educação de jovens e adultos trabalhadores. PERSPECTIVA, Florianópolis, v. 31, n. 2, 405-423 maio/ago. 2013.

SAVIANI, Demerval. Sobre a natureza e especificidade da educação. Comunicação apresentada na Mesa-Redonda sobre a "Natureza e Especificidade da Educação", realizada pelo INEP, em Brasília, no dia 5 de julho de 1984. Em aberto, Brasília, ano 3, n. 22, jul./ago. 1984.

Os saberes implicados na formação do educador. In: BICUDO, M. A.; SILVA JUNIOR, C. A. (Orgs.). Formação do educador: dever do Estado, tarefa da universidade. 1996.

A política educacional no Brasil. In: Stephanou, M e Camara, M H B. (Org.). História e memórias da educação no Brasil. Vol III - Século XX, Editora Vozes. Petrópolis, RJ, 2005.

Formação de professores: aspectos históricos e teóricos do problema no contexto brasileiro. Revista Brasileira de Educação, v. 14 n. 40, jan/abr. 2009.

SANTOS, Maria do Carmo dos. Sob a égide do conflito: a reforma da educação profissional no CEFET-BA. Tese (doutorado) - Universidade Federal da Bahia, Faculdade de Educação, 2005.

SANTOS, Deribaldo; JIMENEZ, Susana; SEGUNDO, Maria das Dores Mendes. Sorria! Você está sendo educado para o trabalho: uma análise crítica da expansão da graduação tecnológica brasileira. In: Educação pública, formação profissional e crise do capitalismo contemporâneo. SANTOS, Deribaldo; JIMENEZ, Susana; VIANA, Cleide Maria Quevedo Quixadá; RABELO, Jackline (Orgs.). Fortaleza: EdUECE, 2013.

SHIROMA, Eneida Oto; CAMPOS, Roselane Fátima; GARCIA, Rosalba Maria Cardoso. Decifrar textos para compreender a política: subsídios teóricometodológicos para análise de documentos. PERSPECTIVA, Florianópolis, v. 23, n. 02, p. 427-446, jul./dez. 2005.

SILVA, Caetana Juracy Rezende (Org.) Institutos Federais lei 11.892, de 29/11/2008: comentários e reflexões / organização, Caetana Juracy Resende Silva. - Natal: IFRN, 2009.

SILVA, Kátia Regina de Souza. Organismos internacionais e política de educação superior na periferia do capitalismo. In: $26^{\mathrm{a}}$ Reunião Anual da ANPEd "Novo Governo. Novas Políticas?” GT: Política de Educação Superior /n.11. Poços de Caldas, 5 a 8 de outubro de 2003.

SILVA, Kátia Augusta Curado Pinheiro Cordeiro da; LIMONTA, Sandra Valéria. Formação de professores em uma perspectiva crítico-emancipadora: a materialidade da utopia. In: SILVA, Kátia Augusta Curado Pinheiro Cordeiro da; LIMONTA, Sandra Valéria (Orgs.). Formação de Professores na perspectiva crítica: resistência e utopia. Brasília: Editora UnB, 2014. 
SILVA, Maria Abádia da. O consenso de Washington e a privatização na educação brasileira. Linhas Críticas, Brasília, v. 11, n. 21, p. 255-264, jan./jun. 2005.

SILVEIRA, Renê José Tentin. O professor e a transformação da realidade. Nuances, vol. $1-\mathrm{n}^{\circ} 1$, setembro de 1995 .

SOUSA, José Vieira. Método materialista histórico-dialético e pesquisa em políticas educacionais: uma relação em permanente construção. In: CUNHA, Célio da; SOUSA, José Vieira; SILVA, Maria Abádia (Org.). O método dialético na pesquisa em educação. Campinas - SP: Autores Associados/ Brasília - DF: Faculdade de Educação, Universidade de Brasília, Unb, 2014.

SOUZA, Francisco C. Silva; NASCIMENTO, Viviane S. de Oliveira. Bacharéis professores: um perfil em expansão na Rede Federal de Educação Profissional e Tecnológica. In: MOURA, Dante Henrique (Org.). Produção de conhecimentos, políticas públicas e formação docente em educação profissional. Campinas - SP: Mercado das Letras. 2013.

TÁVOORA, Luciana; DIAS, Adriano; MELO, Lúcia; KELNER, Sérgio. Institutos Federais de Educação, Ciência e Tecnologia e o apoio à inovação tecnológica: análise e recomendações. In: XVI Congresso Latino-Iberoamericano de Gestão da Tecnologia - ALTEC, 2015.

TARDIF, Maurice; LESSARD, Claude. O trabalho docente: elementos para uma teoria da docência como profissão de interações humanas. $8^{\mathrm{a}}$ Ed. Petrópolis, RJ: Vozes, 2014.

TONET, Ivo. Cidadania ou emancipação humana. Revista Espaço Acadêmico. № 44, jan. 2005.

Um novo horizonte para a educação. Conferência pronunciada no I Congresso de Ontologia do Ser Social e Educação, promovido pelo IBILCE-UNESP. São José do Rio Preto, nov/dez. 2007.

TORRIGLIA, Patrícia Laura; ORTIGARA, Vidalcir. O campo das mediações primeiras aproximações para a pesquisa em políticas educacionais In: CUNHA, Célio da; SOUSA, José Vieira; SILVA, Maria Abádia (Org.). O método dialético na pesquisa em educação. Campinas - SP: Autores Associados/ Brasília - DF: Faculdade de Educação, Universidade de Brasília, UnB, 2014.

TUPPY, Maria Isabel Nogueira. A educação profissional In: OLIVEIRA, R.P. ADRIÃO, T. (Org.). Organização do ensino no Brasil - níveis e modalidades na Constituição e na LDB. São Paulo: Xamã, 2007.

VARGAS, Ana Cristina L. A face dependente do capitalismo brasileiro e a política de formação para a classe trabalhadora. Anais do II Colóquio Nacional - A Produção do Conhecimento em Educação Profissional. Natal: IFRN, 2013.

VERDUM, Priscila de Lima. Formação inicial de professores para educação básica, no contexto dos IFs: propondo indicadores de qualidade, a partir de um estudo de caso no IFRS. Tese (Doutorado) - Programa de Pós-Graduação em Educação, Pontifícia Universidade Católica do Rio Grande do Sul. Porto Alegre / RS, 2015.

VIEIRA JÚNIOR, Paulo Roberto; OLIVEIRA, Maria Auxiliadora Monteiro e GOES, Flávia Temponi. Adoecimento docente na Rede Federal de Educação profissional científica e tecnológica em Minas Gerais. Um fenômeno possível? In: IV Seminário Nacional de Educação Profissional e Tecnológica (SENEPT), 2014. 
VILELA, Elena Fátima; GARCIA, Fernando Coutinho; VIEIRA, Adriane. Vivências de prazer-sofrimento no trabalho do professor universitário: estudo de caso em uma instituição pública. REAd | Porto Alegre - Edição 75 - $\mathrm{N}^{\circ} 2$ - p. 517-540. maio/agosto 2013.

YAMANOE, Mayara Cristina Pereira. Trabalho docente e subjetividade: a identidade do professor do ensino superior e a lógica de produtividade do capital. X Jornada Histedbr, Vitória da Conquista-BA, 2011. 


\section{APÊNDICE}

\section{Quadro 6 - Eixos de análise, unidades temáticas, subunidades temáticas e frequências decorrentes dos questionários.}

\begin{tabular}{|c|c|c|c|}
\hline $\begin{array}{c}\text { UNIDADES } \\
\text { DE } \\
\text { ANÁLISE }\end{array}$ & $\begin{array}{l}\text { UNIDADES } \\
\text { TEMÁTICAS }\end{array}$ & $\begin{array}{l}\text { SUBUNIDADES TEMÁTICAS } \\
\text { (Respostas dos professores) }\end{array}$ & \begin{tabular}{|c}
$\begin{array}{c}\text { FREQUÊNCIA } \\
\text { (quantidade de } \\
\text { ocorrências) }\end{array}$ \\
\end{tabular} \\
\hline \multirow{9}{*}{$\begin{array}{c}\text { Política de } \\
\text { verticalizaçãa } \\
\text { e integração } \\
\text { da educação } \\
\text { básica à } \\
\text { superior }\end{array}$} & \multirow{9}{*}{$\begin{array}{c}\text { Como o professor } \\
\text { se vê no processo } \\
\text { de } \\
\text { desenvolvimento } \\
\text { de políticas } \\
\text { educacionais para } \\
\text { a educação } \\
\text { profissional }\end{array}$} & Receptores passivos da política & 21 \\
\hline & & $\begin{array}{l}\text { Avaliadores ativos da política propondo seu aperfeiçoamento em } \\
\text { nível institucional }\end{array}$ & 15 \\
\hline & & $\begin{array}{l}\text { Agentes indutores na formação da agenda política (apresentando } \\
\text { a necessidade de ação do Estado) }\end{array}$ & 9 \\
\hline & & Participantes ativos nas decisões de implementação da política & 8 \\
\hline & & Agentes sem autonomia para executar a política & 7 \\
\hline & & $\begin{array}{l}\text { Consultores de temáticas relacionadas às políticas a serem } \\
\text { implementadas }\end{array}$ & 6 \\
\hline & & Indutores institucionais da implementação da política & 5 \\
\hline & & $\begin{array}{l}\text { Avaliadores ativos da política propondo seu aperfeiçoamento em } \\
\text { nível regional }\end{array}$ & 4 \\
\hline & & $\begin{array}{l}\text { Avaliadores ativos da política propondo seu aperfeiçoamento em } \\
\text { nível nacional }\end{array}$ & 4 \\
\hline \multirow{32}{*}{$\begin{array}{c}\text { Elementos do } \\
\text { trabalho } \\
\text { docente na } \\
\text { verticalização }\end{array}$} & \multirow{8}{*}{$\begin{array}{l}\text { Formação docente } \\
\text { para atuação } \\
\text { verticalizada e } \\
\text { integrada }\end{array}$} & Licenciatura/ Graduação & 34 \\
\hline & & Pós-graduação stricto sensu e lato sensu & 30 \\
\hline & & Formação técnica/ acadêmica/área específica/ EPT & 16 \\
\hline & & Formação pedagógica/ Didática/ Educação de Jovens e Adultos & 13 \\
\hline & & Experiência profissional / Atualização profissional & 9 \\
\hline & & Humana e social, ética, sócio política. A melhor que puder & 5 \\
\hline & & Pedagogia/ Magistério/ Educação Especial & 4 \\
\hline & & Certificado de língua estrangeira/ Cursos no exterior & 2 \\
\hline & \multirow{10}{*}{$\begin{array}{c}\text { Ações } \\
\text { desenvolvidas } \\
\text { pelo sindicato para } \\
\text { formação e } \\
\text { profissionalização } \\
\text { dos professores }\end{array}$} & Desconheço/ não tenho opinião/ Atuação insatisfatória & 25 \\
\hline & & Atua na busca de cursos/ apoia nossas ações & 3 \\
\hline & & Preocupação primordial é a progressão salarial/carreira & 3 \\
\hline & & Formação docente depende exclusivamente do docente & 2 \\
\hline & & É altamente ideológico/ O outro sindicato tem melhor atuação & 2 \\
\hline & & Busca melhorar as condições de trabalho & 1 \\
\hline & & Falta preocupação com a formação técnica do docente & 1 \\
\hline & & Falta articulação política e formação sindical & 1 \\
\hline & & Não é essa a finalidade do sindicato & 1 \\
\hline & & Pouco entrosamento entre o sindicato e o IFB & 1 \\
\hline & \multirow{14}{*}{$\begin{array}{c}\text { Atividades de } \\
\text { gestão, ensino, } \\
\text { pesquisa e } \\
\text { extensão } \\
\text { desenvolvidas no } \\
\text { IFB }\end{array}$} & Sobrecarga de trabalho/ com atividades de gestão & 13 \\
\hline & & Falta apoio/ condições para realizar pesquisa e extensão & 11 \\
\hline & & Estou satisfeito com o trabalho/ considero bom & 5 \\
\hline & & Falta estrutura no campus/ estrutura precária & 4 \\
\hline & & Demanda administrativa atrapalha desenvolvimento docente & 3 \\
\hline & & Tenho apoio para realizar meu trabalho/ boa estrutura & 3 \\
\hline & & Não tenho formação para o ensino/ dificuldades para o ensino & 3 \\
\hline & & Gestão precisa melhorar/ Não posso responder, estou na gestão. & 2 \\
\hline & & Preciso me capacitar mais para executar um bom trabalho & 2 \\
\hline & & Apenas organizei eventos & 1 \\
\hline & & Biblioteca poderia ser melhor & 1 \\
\hline & & Prof. temporário não consigo desenvolver pesquisa e extensão & 1 \\
\hline & & Grupos de pesquisa não funcionam no campus & 1 \\
\hline & & Satisfação apenas no ensino, não pude me dedicar ao resto. & 1 \\
\hline
\end{tabular}




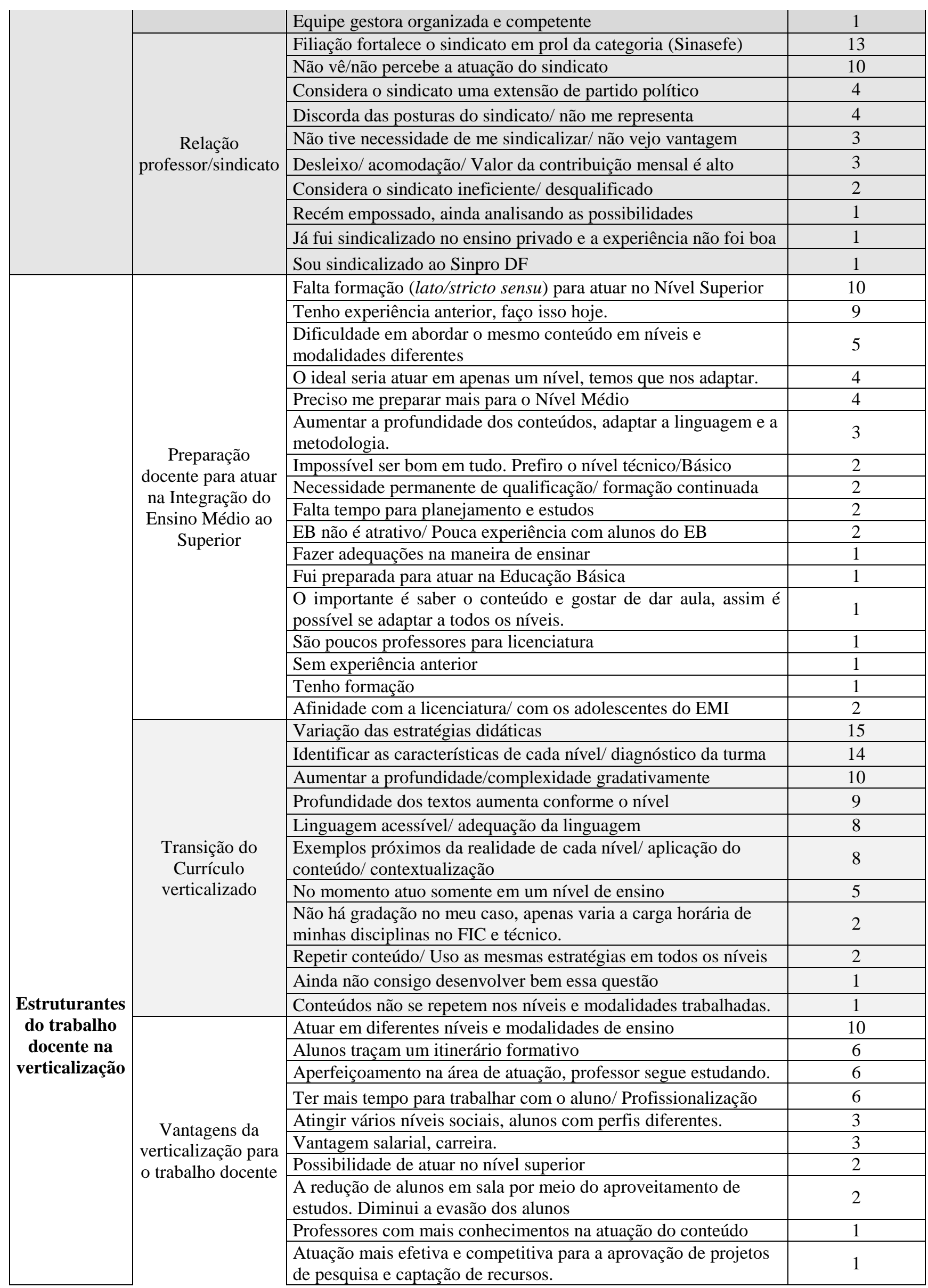




\begin{tabular}{|c|c|c|}
\hline & Formação de colegiados de professores & 1 \\
\hline \multirow{8}{*}{$\begin{array}{l}\text { Desvantagens da } \\
\text { verticalização para } \\
\text { o trabalho docente }\end{array}$} & $\begin{array}{l}\text { Não realizar um trabalho bem feito por atuar em áreas diversas, } \\
\text { assumir funções de gestão, excesso de atividades, rotina } \\
\text { desgastante, falta de tempo. }\end{array}$ & 13 \\
\hline & Dificuldade em trabalhar diferentes níveis e modalidades & 11 \\
\hline & Não vejo desvantagens/ desde que feita conforme consta em lei. & 7 \\
\hline & Reorganizar conteúdos de acordo com o nível e modalidade & 2 \\
\hline & Nível de exigência do trabalho aumenta/ baixo salário & 2 \\
\hline & Baixa rotatividade dos alunos & 1 \\
\hline & Professor não tem formação para o nível e modalidade & 1 \\
\hline & Falta acompanhamento de déficits da educação básica. & 1 \\
\hline
\end{tabular}

Fonte: entrevistas da pesquisa, 2016.

\section{Quadro 7 - Eixos de análise, unidades temáticas, subunidades temáticas e frequências decorrentes das entrevistas.}

\begin{tabular}{|c|c|c|c|}
\hline $\begin{array}{c}\text { UNIDADES } \\
\text { DE } \\
\text { ANÁLISE }\end{array}$ & $\begin{array}{l}\text { UNIDADES } \\
\text { TEMÁTICAS }\end{array}$ & $\begin{array}{l}\text { SUBUNIDADES TEMÁTICAS } \\
\text { (Respostas dos professores) }\end{array}$ & $\begin{array}{l}\text { FREQUÊNCIA } \\
\text { (quantidade de } \\
\text { ocorrências) }\end{array}$ \\
\hline \multirow{10}{*}{$\begin{array}{c}\text { Política de } \\
\text { verticalização } \\
\text { e integração } \\
\text { da educação } \\
\text { básica à } \\
\text { superior }\end{array}$} & \multirow{6}{*}{$\begin{array}{l}\text { Política de criação } \\
\text { dos IFs }\end{array}$} & Positiva/ favorável/bem intencionada/romântica & 7 \\
\hline & & Não tinha a perspectiva de várias modalidades no mesmo espaço & 6 \\
\hline & & $\begin{array}{l}\text { Descentralizar/ Expandir o acesso EPT e superior para regiões e } \\
\text { pessoas desfavorecidas. }\end{array}$ & 5 \\
\hline & & Formar cidadãos capacitados para o desenvolvimento regional & 2 \\
\hline & & A expansão feita de forma acelerada/precarizada & 2 \\
\hline & & Sabia da possibilidade de atuar em níveis e modalidades diferentes & 2 \\
\hline & \multirow{2}{*}{$\begin{array}{c}\text { Política de } \\
\text { verticalização e o } \\
\text { trabalho docente }\end{array}$} & $\begin{array}{l}\text { Possibilidade de o aluno seguir de um curso técnico para um } \\
\text { tecnólogo, valorizar a profissão técnica. }\end{array}$ & 1 \\
\hline & & A impossibilidade de dominar todas as áreas & 1 \\
\hline & \multirow{2}{*}{$\begin{array}{c}\text { Conhecimento } \\
\text { prévio sobre a } \\
\text { política de } \\
\text { verticalização }\end{array}$} & Faltou formação do professor, que tem que aprender fazendo. & 1 \\
\hline & & Quantidade professor/aluno não é factível para todos os cursos. & 1 \\
\hline \multirow{15}{*}{$\begin{array}{l}\text { Elementos do } \\
\text { trabalho } \\
\text { docente na } \\
\text { verticalização }\end{array}$} & \multirow{7}{*}{$\begin{array}{l}\text { Formação docente } \\
\text { para atuação } \\
\text { verticalizada e } \\
\text { integrada }\end{array}$} & Formações continuadas para níveis e modalidades específicas & 3 \\
\hline & & O IFB deve oferecer formação para atuação na verticalização & 2 \\
\hline & & Não vê necessidade de formação para atuar no nível superior & 1 \\
\hline & & Atualização na própria área de conhecimento & 1 \\
\hline & & Perfil acadêmico para o nível superior artístico para o nível médio & 1 \\
\hline & & Formacão política & 1 \\
\hline & & \begin{tabular}{|llll}
$\begin{array}{l}\text { Excesso de trabalho, atividades burocráticas dificultam a } \\
\text { disponibilidade para formação. }\end{array}$ & & \\
\end{tabular} & 1 \\
\hline & \multirow{5}{*}{$\begin{array}{l}\text { Divisão da carga } \\
\text { horária docente } \\
\text { diante das } \\
\text { características da } \\
\text { verticalização }\end{array}$} & Professores do mesmo grupo se reúnem e fazem a divisão & 2 \\
\hline & & Não está institucionalizado, cada campus conduz de uma maneira. & 1 \\
\hline & & Grande quantidade de componentes diferentes & 1 \\
\hline & & $\begin{array}{l}\text { Professores não têm formação para determinada área e não } \\
\text { querem dar aula em alguns cursos }\end{array}$ & 1 \\
\hline & & $\begin{array}{l}\text { Avaliação externa exige professores com pós-graduação nos } \\
\text { cursos superiores }\end{array}$ & 1 \\
\hline & \multirow{3}{*}{$\begin{array}{l}\text { Condições de } \\
\text { trabalho }\end{array}$} & $\begin{array}{l}\text { Professor divide suas horas pra várias áreas/ quantidade excessiva } \\
\text { de componentes curriculares diferentes }\end{array}$ & 4 \\
\hline & & $\begin{array}{l}\text { Boas condições de trabalho, de preparar material e outras } \\
\text { atividades. }\end{array}$ & 2 \\
\hline & & Planejamento e tempo pra reuniões ficam comprometidos & 3 \\
\hline
\end{tabular}




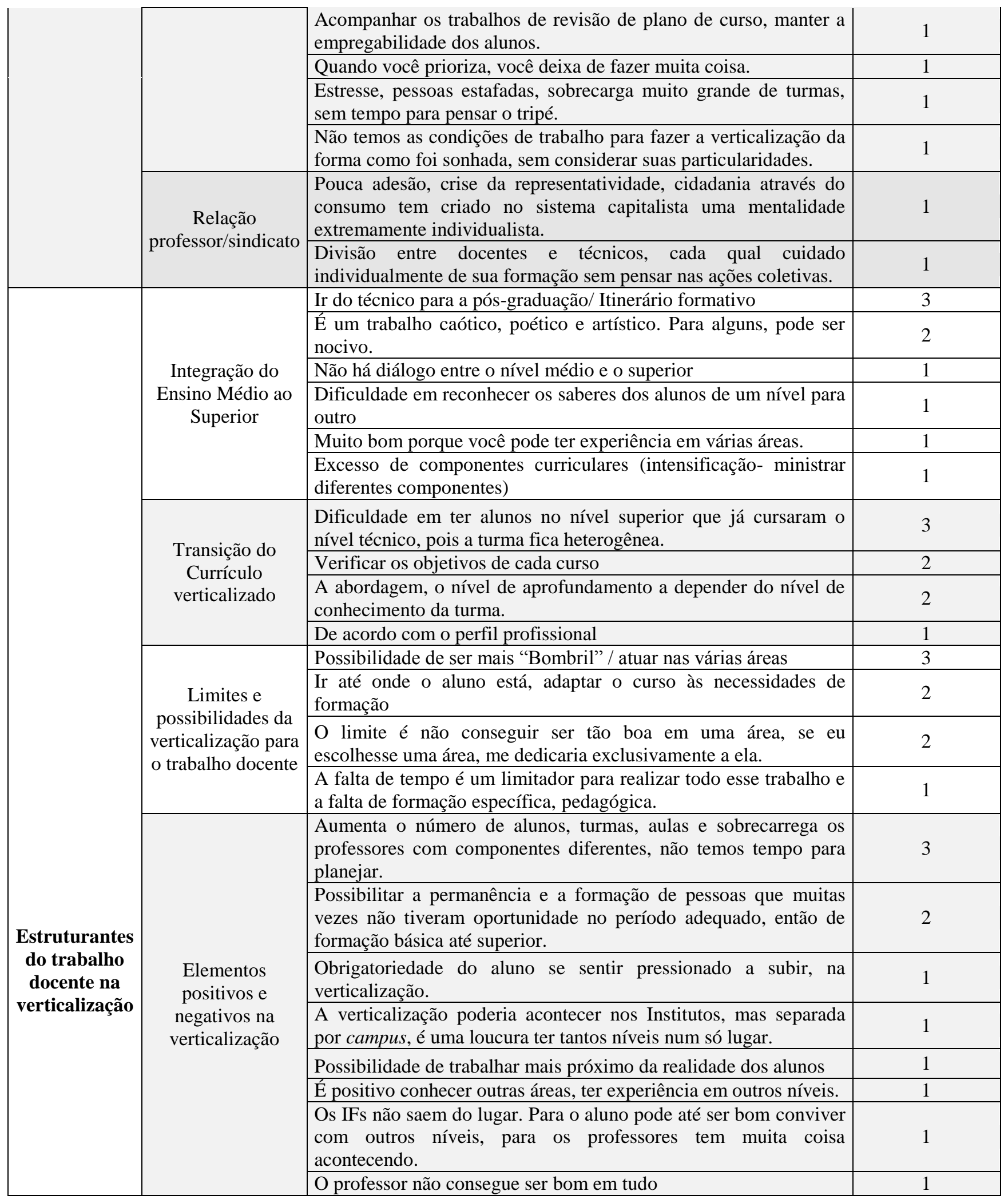




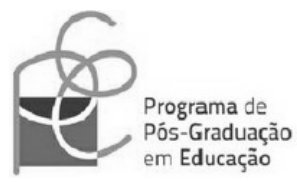

\section{UNIVERSIDADE DE BRASÍLIA - UnB \\ FACULDADE DE EDUCAÇÃO - FE \\ PROGRAMA DE PÓS-GRADUAÇÃO EM EDUCAÇÃO \\ GRUPO DE ESTUDOS E PESQUISAS SOBRE FORMAÇÃO E ATUAÇÃO DE PROFESSORES / PEDAGOGOS - GEPFAPe}

\section{Questionário - Trabalho docente no Instituto Federal de Brasília}

Cara professora e caro professor ${ }^{36}$,

Pedimos a gentileza de colaborar voluntariamente com nossa pesquisa respondendo a este questionário que tem como objetivos identificar e analisar o trabalho docente no IFB. As informações fornecidas por você terão o sigilo garantido e serão fundamentais para o andamento da pesquisa. Caso não queira, não é necessário escrever o seu nome, apenas as demais informações para que possamos traçar o perfil do docente do IFB.

\begin{tabular}{|l|l|}
\hline Nome (opcional): & \\
\hline Campus de exercício: & \\
\hline E-mail: & \\
\hline
\end{tabular}

\section{Esses dados são restritos e confidenciais.}

Você poderia nos conceder uma entrevista posteriormente? Sim ( ) Não ( )

Telefone:

Agradecemos sua disponibilidade e nos colocamos à sua disposição para quaisquer esclarecimentos.

Profa. Dra. Shirleide Pereira da Silva Cruz

E-mail: shirleidesc@gmail.com

Fone: (61) 9277-0504

Profa. Dra. Kátia Augusta Curado Pinheiro Cordeiro da Silva

E-mail: katiacurado@unb.br

Fone: (61) 9879-5649

Código do questionário (preenchimento interno da pesquisa):

\footnotetext{
${ }^{36}$ Com a finalidade de tornar a leitura mais dinâmica e menos cansativa, utilizaremos a norma culta padrão da língua portuguesa ao tratar professoras e professores como "professor" da Educação Básica Técnica e Tecnológica (EBTT).
} 
I-PERFIL:

1. Idade:

Até 20 anos

De 21 a 25 anos

De 26 a 30 anos

De 31 a 35 anos

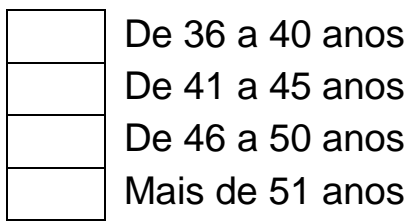

2. Sexo:

Masculino

Feminino

3. Estado civil:

\begin{tabular}{|l|l|}
\hline & Casado \\
\hline & Solteiro \\
& Viúvo
\end{tabular}

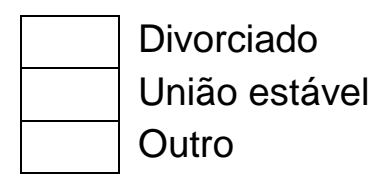

4. Número de filhos:
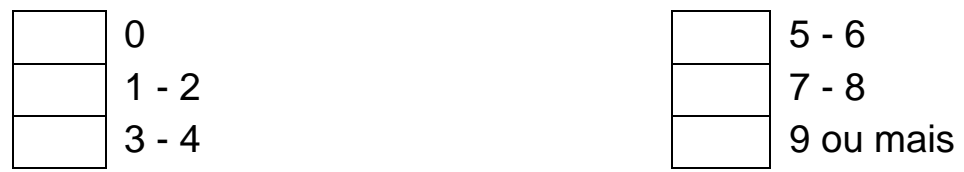

5. Identifique sua faixa salarial:
Até 2 salários mínimos
Até $\mathrm{R} \$ 1.760,00$
De 2 a 4 salários mínimos
De $R \$ 1.760,00$ a $R \$ 3.520,00$
De 4 a 10 salários mínimos
De $R \$ 3.520,00$ a $R \$ 8.800,00$
De 10 a 20 salários mínimos
$\mathrm{De} R \$ 8.800,00$ a $\mathrm{R} \$ 17.600,00$
Acima de 20 salários mínimos
Acima de $\mathrm{R} \$ 17.600,00$

6. Identifique sua renda familiar mensal:
Até 2 salários mínimos
Até $\mathrm{R} \$ 1.760,00$
De 2 a 4 salários mínimos
De $R \$ 1.760,00$ a $R \$ 3.520,00$
De 4 a 10 salários mínimos
De $R \$ 3.520,00$ a $R \$ 8.800,00$
De 10 a 20 salários mínimos
De $R \$ 8.800,00$ a $R \$ 17.600,00$
Acima de 20 salários mínimos
Acima de $R \$ 17.600,00$ 
7. Indique sua formação acadêmica (marque todas as opções que se aplicam a você):

\begin{tabular}{|c|c|c|c|c|}
\hline Assinale & Formação: & Especificar: & & \\
\hline ( ) & Curso técnico & & & \\
\hline$(\quad)$ & 1a Graduação & Licenciatura ( ) & Bacharelado ( ) & Tecnólogo ( ) \\
\hline & & Qual: & & \\
\hline$(\quad)$ & 2ª Graduação & Licenciatura ( ) & Bacharelado ( ) & Tecnólogo ( ) \\
\hline & & Qual: & & \\
\hline$(\quad)$ & Especialização & & & \\
\hline$(\quad)$ & Mestrado acadêmico & & & \\
\hline$(\quad)$ & Mestrado profissional & & & \\
\hline$(\quad)$ & Doutorado & & & \\
\hline$(\quad)$ & Pós-Doutorado & & & \\
\hline
\end{tabular}

\section{Qual a sua profissão?}

9. Sobre sua experiência profissional prévia ao IFB:

a) Você já atuou como docente antes de ingressar do IFB? ( ) sim ( ) não

b) Caso a resposta seja positiva, em quais níveis e modalidades de ensino você já atuou antes de ingressar no IFB?
( ) Educação Infantil
( ) Ensino Fundamental
( ) Ensino Médio
( ) Ensino Superior
( ) Educação Profissional

c) Você atua há quantos anos no Ensino Público?

d) Você atua ou já atuou no ensino privado?

Sim ( ) Há quantos anos?

Não ( )

e) Você tem experiência profissional no eixo tecnológico oferecido pelo seu campus?

( ) $\operatorname{sim}(\quad)$ não

\section{II-ATUACC̃̃O PROFISSIONAL NO IFB:}

10. Indique sua situação funcional no IFB:

Ativo permanente - professor efetivo

Professor temporário

Professor substituto 
11. Indique o seu regime de trabalho no IFB:

$40 \mathrm{~h} \quad$ Dedicação
Exclusiva
$40 \mathrm{~h}$
$20 \mathrm{~h}$

12. Sua expectativa antes de entrar no IFB era atuar no:

\begin{tabular}{|l|l|l|}
\hline & Ensino & Ensino Básico \\
\hline & Pesquisa & Ensino técnico profissional \\
& Extensão & Ensino superior \\
\hline Outro(s). Especifique: & \\
\hline
\end{tabular}

Por que?

13. Indique os níveis, modalidades e programas nos quais você já atuou desde que tomou posse no IFB (marque mais de uma opção, se for o seu caso):

Formação Inicial e Continuada (FIC)

EaD

Pronatec

Proeja

Ensino Médio Técnico Integrado

Ensino Médio Técnico Subsequente

Ensino Médio Técnico Concomitante

Graduação - Licenciatura

Graduação - Tecnólogo

Graduação - Bacharelado

Pós-Graduação - Especialização

Outros:

14. Indique sua carga horária em sala de aula no IFB neste semestre:

\begin{tabular}{|l|l|l|}
\hline & Menos que 8h & $16 \mathrm{~h}$ \\
\hline $8 \mathrm{~h}$ & $17 \mathrm{~h}$ \\
\hline $9 \mathrm{~h}$ & $18 \mathrm{~h}$ \\
\hline $10 \mathrm{~h}$ & $19 \mathrm{~h}$ \\
\hline $11 \mathrm{~h}$ & $20 \mathrm{~h}$ \\
\hline $12 \mathrm{~h}$ & $21 \mathrm{~h}$ \\
\hline $13 \mathrm{~h}$ & $22 \mathrm{~h}$ \\
\hline $14 \mathrm{~h}$ & $23 \mathrm{~h}$ \\
\hline $15 \mathrm{~h}$ & $24 \mathrm{~h}$ \\
\hline & \\
\hline
\end{tabular}


15. Quantos componentes curriculares (disciplinas) você leciona neste semestre, no IFB?
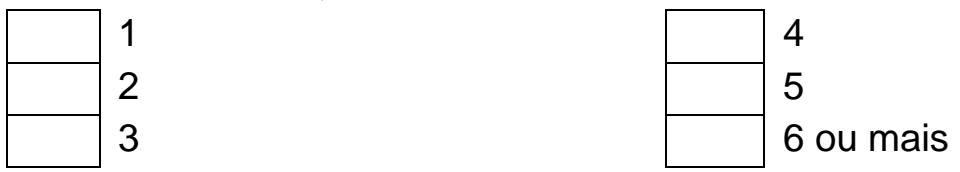

16. Você atua ou já atuou em cargos de gestão desde que tomou posse no IFB? (marque mais de uma alternativa, se for o seu caso).

Não

Direção Geral

Direção Administrativa

Direção de Ensino Pesquisa e Extensão

Pró-Reitoria

Coordenação Geral de Ensino

Coordenação Pedagógica

Coordenação de Pesquisa e Extensão

Coordenação de Estágio

Coordenação CDAE

Coordenação de Curso

Outros:

17. No IFB você realiza ou já realizou as atividades de:

Pesquisa ( ) sim ( ) não

Extensão ( ) sim ( ) não Publicação de artigos ( ) sim ( ) não

18. Quais são as vantagens do seu trabalho no IFB? (Marque mais de uma opção caso julgue necessário):

\begin{tabular}{|l|l|l|l|}
\hline & Autonomia & & Realização Pessoal \\
\hline & Carga horária & & Relação interpessoal \\
\hline & Flexibilidade da carga horária & & Rotina \\
\hline & Oferta do mercado de trabalho & & Salário \\
\hline & Plano de carreira & & Outro? \\
\hline
\end{tabular}


19. Quais são as desvantagens do seu trabalho no IFB? (Marque mais de uma opção caso julgue necessário):

\begin{tabular}{|l|l|l|l|}
\hline & Competição entre os pares & & Plano de carreira \\
\hline & Desgaste emocional & & Produtividade \\
\hline & Desgaste físico & & Relação interpessoal \\
\hline & Falta de autonomia & & Rotina \\
\hline & Flexibilidade da carga horária & & Salário \\
\hline & Oferta do mercado de trabalho & & Outro? \\
\hline
\end{tabular}

20. Você conhece a política de verticalização dos Institutos Federais?

$\operatorname{Sim}$ Não

21. Cite uma vantagem da verticalização para o seu trabalho:

22. Cite uma desvantagem da verticalização para o seu trabalho:

23. Para as afirmações abaixo indique seu nível de concordância:

\begin{tabular}{|l|c|c|c|c|}
\hline a) $\begin{array}{l}\text { No meu trabalho como } \\
\text { professor do IFB eu } \\
\text { considero ter poder } \\
\text { decisório sobre o que e } \\
\text { como ensinar }\end{array}$ & $\begin{array}{c}\text { Não } \\
\text { concordo } \\
\text { totalmente }\end{array}$ & $\begin{array}{c}\text { Não } \\
\text { concordo } \\
\text { parcialmente }\end{array}$ & $\begin{array}{c}\text { Concordo } \\
\text { parcialmente }\end{array}$ & $\begin{array}{c}\text { Concordo } \\
\text { totalmente }\end{array}$ \\
\hline b) $\begin{array}{l}\text { Otempo que tenho } \\
\text { destinado Não }\end{array}$ & $\begin{array}{c}\text { Não } \\
\text { concordo } \\
\text { planejamento didático é } \\
\text { suficiente para a } \\
\text { organização do meu } \\
\text { trabalho pedagógico no }\end{array}$ & $\begin{array}{c}\text { Concordo } \\
\text { parcialmente }\end{array}$ & $\begin{array}{c}\text { Concordo } \\
\text { totalmente }\end{array}$ \\
IFB & & & \\
\end{tabular}




\begin{tabular}{|c|c|c|c|c|c|}
\hline & $\begin{array}{l}\text { O campus oferece local } \\
\text { adequado para que eu } \\
\text { realize minhas atividades } \\
\text { de planejamento } \\
\text { pedagógico/didático }\end{array}$ & $\begin{array}{c}\text { Não } \\
\text { concordo } \\
\text { totalmente }\end{array}$ & $\begin{array}{c}\text { Não } \\
\text { concordo } \\
\text { parcialmente }\end{array}$ & $\begin{array}{c}\text { Concordo } \\
\text { parcialmente }\end{array}$ & $\begin{array}{c}\text { Concordo } \\
\text { totalmente }\end{array}$ \\
\hline d) & $\begin{array}{l}\text { O espaço físico do meu } \\
\text { campus adequado para } \\
\text { receber cursos FIC, cursos } \\
\text { de ensino } r \text { médio } \\
\begin{array}{l}\text { profissional e cursos } \\
\text { superiores }\end{array}\end{array}$ & $\begin{array}{c}\text { Não } \\
\text { concordo } \\
\text { totalmente }\end{array}$ & $\begin{array}{c}\text { Não } \\
\text { concordo } \\
\text { parcialmente }\end{array}$ & $\begin{array}{c}\text { Concordo } \\
\text { parcialmente }\end{array}$ & $\begin{array}{c}\text { Concordo } \\
\text { totalmente }\end{array}$ \\
\hline e) & $\begin{array}{l}\text { A biblioteca do meu } \\
\text { campus adequada para } \\
\text { atender a demanda dos } \\
\text { professores dos cursos } \\
\text { FIC, cursos de ensino } \\
\text { médio profissional e } \\
\text { cursos superiores }\end{array}$ & $\begin{array}{c}\text { Não } \\
\text { concordo } \\
\text { totalmente }\end{array}$ & $\begin{array}{c}\text { Não } \\
\text { concordo } \\
\text { parcialmente }\end{array}$ & $\begin{array}{c}\text { Concordo } \\
\text { parcialmente }\end{array}$ & $\begin{array}{c}\text { Concordo } \\
\text { totalmente }\end{array}$ \\
\hline
\end{tabular}

24. O tempo que você gasta nos diferentes conjuntos e tarefas docentes no IFB (preparação de aulas, estudo, elaboração de materiais, planejamento, avaliação, correção e registro de atividades de ensino, preenchimento de diários) extrapola sua carga horária de regime de trabalho semanal?

$\square \operatorname{Sim}$

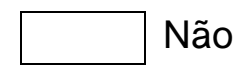

Se sim, qual a média de horas a mais que você gasta por semana?

25. Classifique o seu grau de satisfação com as atividades (gestão, ensino, pesquisa e extensão) que você desenvolve no IFB:

\begin{tabular}{|l|l|l|l|}
\hline & Muito bom & & Ruim \\
\hline & Bom & & Muito Ruim \\
\hline & Razoável & & Péssimo \\
\hline
\end{tabular}

\section{Comente:}




\section{III-SOCIAL:}

26. Escolha, para cada item, a resposta que indica o nível de importância que você considera para as atividades de manifestações culturais das quais participa:

\begin{tabular}{|l|l|l|l|l|}
\hline \multicolumn{1}{|c|}{ ITENS } & $\begin{array}{c}\text { Nada } \\
\text { importante }\end{array}$ & $\begin{array}{c}\text { Pouco } \\
\text { importante }\end{array}$ & $\begin{array}{c}\text { Muito } \\
\text { importante }\end{array}$ & $\begin{array}{c}\text { Extremamente } \\
\text { importante }\end{array}$ \\
\hline $\begin{array}{l}\text { Assistir apresentações de } \\
\text { manifestações populares }\end{array}$ & & & & \\
\hline Frequentar biblioteca & & & & \\
\hline Frequentar livraria & & & & \\
\hline Ir a concertos & & & & \\
\hline Ir a espetáculos de dança & & & & \\
\hline Ir a exposições & & & & \\
\hline Ir a museus & & & & \\
\hline Ir ao circo & & & & \\
\hline Ir ao teatro & & & & \\
\hline Ler jornais & & & & \\
\hline
\end{tabular}

27. Como você percebe o nível de reconhecimento social em relação ao profissional professor do IFB?

\begin{tabular}{|l|l|l|l|}
\hline & Muito bom & & Ruim \\
\hline & Bom & & Muito Ruim \\
\hline & Razoável & & Péssimo \\
\hline
\end{tabular}


III - PERFIL POLÍTICO:

28. Você participa de atividades político-sociais?

\begin{tabular}{|l|}
\hline $\operatorname{Sim} \quad \square$ Não \\
\hline Quais? \\
\hline
\end{tabular}

29. Você é sindicalizado?

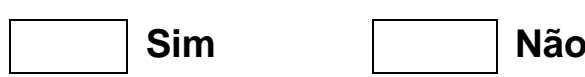

Justifique sua resposta:

30. Você percebe o sindicato como entidade representativa dos professores do IFB?

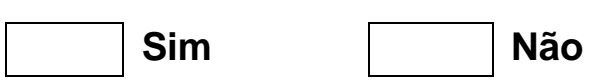

\begin{tabular}{|l|}
\hline Justifique: \\
\hline \\
\hline
\end{tabular}

31. Você considera que as ações desenvolvidas pelo sindicato têm contribuído com a formação e profissionalização dos professores do IFB?

\begin{tabular}{ll}
$\square$ Sim $\quad \square$ Não \\
\hline
\end{tabular}

Justifique: 
32. Classifique o seu grau de satisfação para com o seu trabalho docente no IFB:

\begin{tabular}{|l|l|l|l|}
\hline & Muito bom & & Ruim \\
\hline & Bom & & Muito Ruim \\
\hline & Médio & & Péssimo \\
\hline
\end{tabular}

\section{Comente:}

\section{IV - CONHECIMENTOS DOCENTES NECESSÁRIOS PARA ATUACÃO NO IFB}

33. Qual formação você considera necessária para ser professor no IFB?

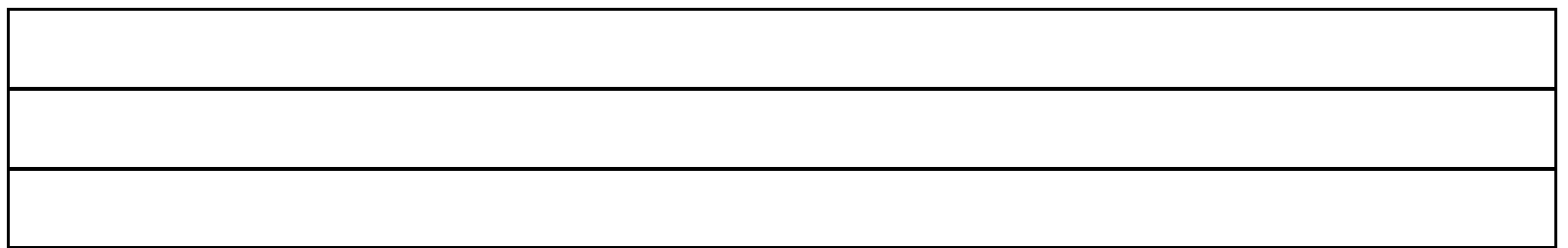

34. Leia cada afirmação e assinale o item que mais se aproxima de sua opinião:

\begin{tabular}{|c|c|c|c|c|c|}
\hline & $\begin{array}{l}\text { Um bom docente no } \\
\text { ensino médio técnico } \\
\text { será um bom docente } \\
\text { no ensino superior } \\
\text { (graduação e/ou pós- } \\
\text { graduação) }\end{array}$ & $\begin{array}{l}\text { Não concordo } \\
\text { totalmente }\end{array}$ & $\begin{array}{c}\text { Não } \\
\text { concordo } \\
\text { parcialmente }\end{array}$ & $\begin{array}{c}\text { Concordo } \\
\text { parcialmente }\end{array}$ & $\begin{array}{l}\text { Concordo } \\
\text { totalmente }\end{array}$ \\
\hline b) & $\begin{array}{l}\text { Para ser professor o } \\
\text { fundamental é saber o } \\
\text { conteúdo }\end{array}$ & $\begin{array}{l}\text { Não concordo } \\
\text { totalmente }\end{array}$ & $\begin{array}{c}\text { Não } \\
\text { concordo } \\
\text { parcialmente }\end{array}$ & $\begin{array}{c}\text { Concordo } \\
\text { parcialmente }\end{array}$ & $\begin{array}{l}\text { Concordo } \\
\text { totalmente }\end{array}$ \\
\hline c) & $\begin{array}{l}\text { Sou professor porque } \\
\text { me identifico com área } \\
\text { de conhecimento }\end{array}$ & $\begin{array}{c}\text { Não concordo } \\
\text { totalmente }\end{array}$ & $\begin{array}{c}\text { Não } \\
\text { concordo } \\
\text { parcialmente }\end{array}$ & $\begin{array}{c}\text { Concordo } \\
\text { parcialmente }\end{array}$ & $\begin{array}{l}\text { Concordo } \\
\text { totalmente }\end{array}$ \\
\hline d) & $\begin{array}{l}\text { A relação com } 0 \\
\text { estudante no processo } \\
\text { de construção do } \\
\text { conhecimento é muito } \\
\text { importante para a } \\
\text { atuação } \\
\text { professor }\end{array}$ & $\begin{array}{l}\text { Não concordo } \\
\text { totalmente }\end{array}$ & $\begin{array}{c}\text { Não } \\
\text { concordo } \\
\text { parcialmente }\end{array}$ & $\begin{array}{c}\text { Concordo } \\
\text { parcialmente }\end{array}$ & $\begin{array}{l}\text { Concordo } \\
\text { totalmente }\end{array}$ \\
\hline
\end{tabular}


35. Elenque os três ( 1 a 3 em ordem de importância) conhecimentos considerados prioritários para a sua atuação como docente no IFB:

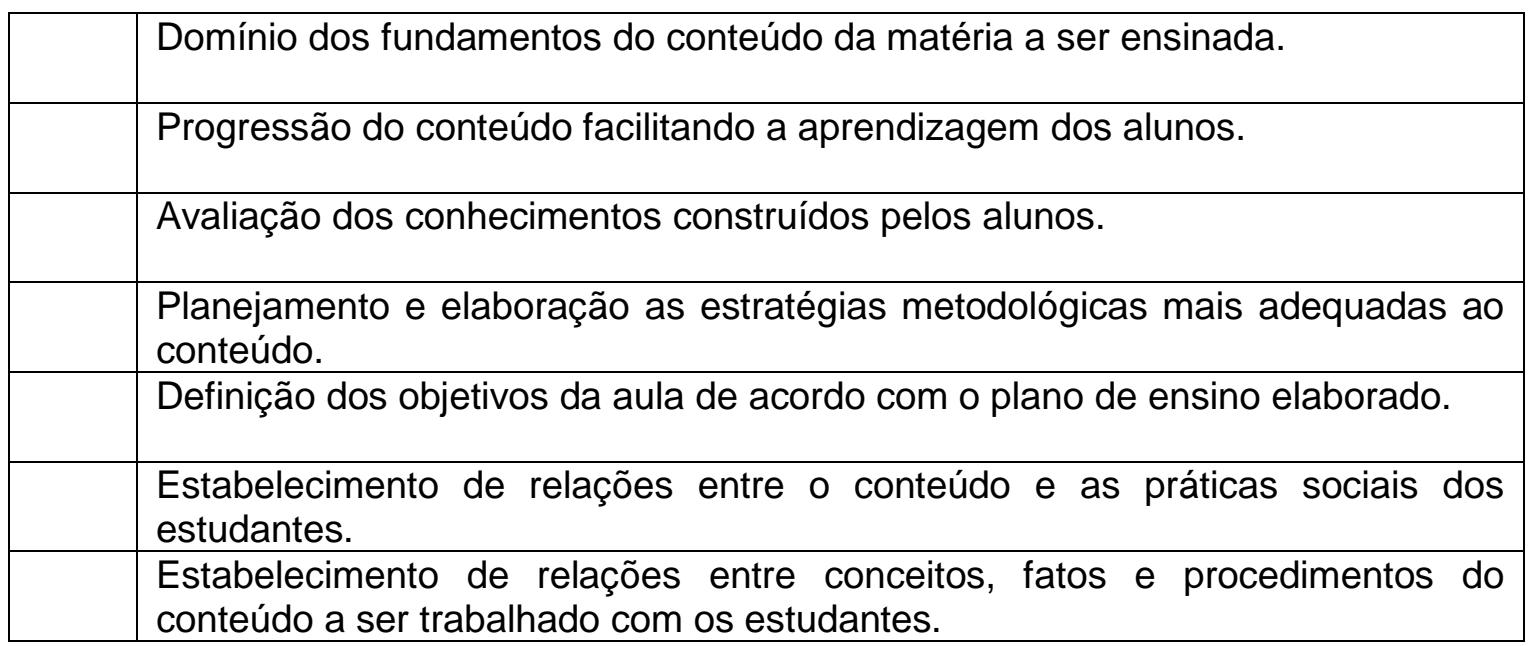

\section{IV - SOBRE A FORMACÃO CONTINUADA PARA SER PROFESSOR}

36. $O$ que você considera como formação continuada para o seu trabalho docente no IFB?

\begin{tabular}{|l|}
\hline \\
\hline \\
\hline
\end{tabular}

37. O IFB estimula e facilita a formação continuada de seus docentes?

$\square$ Sim Não

38. Caso já tenha participado de algum tipo de formação continuada, considera ter sido útil para a sua atuação como docente?

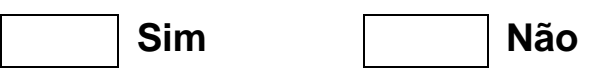

\begin{tabular}{|l|}
\hline Justifique: \\
\hline \\
\hline
\end{tabular}


39. Para as ações de desenvolvimento profissional/ capacitação docente assinale o item que mais se aproxima de sua opinião:

\begin{tabular}{|c|c|c|c|c|}
\hline Ação & Nada importante & $\begin{array}{l}\text { Pouco } \\
\text { importante }\end{array}$ & $\begin{array}{c}\text { Muito } \\
\text { importante }\end{array}$ & $\begin{array}{l}\text { Extremamente } \\
\text { importante }\end{array}$ \\
\hline $\begin{array}{l}\text { A formação na pós- } \\
\text { graduação } \\
\text { (especialização) }\end{array}$ & & & & \\
\hline $\begin{array}{l}\text { A formação na pós- } \\
\text { graduação (mestrado) }\end{array}$ & & & & \\
\hline $\begin{array}{l}\text { A formação na pós- } \\
\text { graduação (doutorado) }\end{array}$ & & & & \\
\hline $\begin{array}{l}\text { A participação em } \\
\text { atividades da } \\
\text { comunidade }\end{array}$ & & & & \\
\hline $\begin{array}{l}\text { Planejamentos } \\
\text { coletivos no instituto }\end{array}$ & & & & \\
\hline Cursos de extensão & & & & \\
\hline Cursos livres & & & & \\
\hline $\begin{array}{l}\text { Encontros e } \\
\text { congressos científicos }\end{array}$ & & & & \\
\hline Estudos individuais & & & & \\
\hline $\begin{array}{l}\text { Os eventos e cursos } \\
\text { promovidos pelo IFB }\end{array}$ & & & & \\
\hline $\begin{array}{l}\text { Os eventos e cursos } \\
\text { promovidos pelo } \\
\text { sindicato }\end{array}$ & & & & \\
\hline $\begin{array}{l}\text { Participação em } \\
\text { grupos de estudos e } \\
\text { pesquisas }\end{array}$ & & & & \\
\hline $\begin{array}{l}\text { Participação em } \\
\text { comissões e grupos de } \\
\text { trabalho }\end{array}$ & & & & \\
\hline $\begin{array}{l}\text { Participação de fóruns } \\
\text { políticos sobre área de } \\
\text { atuação }\end{array}$ & & & & \\
\hline
\end{tabular}


40. Assinale as suas aspirações em relação ao seu futuro como professor ou não professor:

\begin{tabular}{|l|l|}
\hline & Realizar estudos de pós-graduação \\
\hline & Realizar intercâmbio institucional \\
\hline & Assumir cargo de gestão na instituição \\
\hline & Assumir cargo de gestão de políticas de educação profissional \\
\hline & Pedir redistribuição/remoção de campus \\
\hline & Participar de um grupo de pesquisa \\
\hline & Coordenar projetos de extensão \\
\hline & Coordenar projetos de inovação tecnológica \\
\hline & Estudar para outro concurso para professor \\
\hline & Estudar para outro concurso na área técnica \\
\hline & Mudar de profissão \\
\hline & Ser reconhecido como um bom professor \\
\hline
\end{tabular}

\section{V - ORGANIZACÃO DO TRABALHO PEDAGÓGICO}

41. Você planeja as suas aulas no IFB utilizando algum instrumento de registro?

( ) Sim Qual?

( ) Não

42. Como você realiza a seleção dos conteúdos que vai trabalhar com seus alunos?

43. Assinale três estratégias metodológicas que você mais desenvolve em sala de aula (numere de 1 a 3 em ordem de importância):

\begin{tabular}{|l|l|}
\hline & Aula expositiva \\
\hline & Debates \\
\hline & Trabalhos em grupos \\
\hline & Produção textual (resumo, resenha, artigo) \\
\hline & Pesquisa de campo \\
\hline & Visitas técnicas \\
\hline & Práticas de laboratório \\
\hline & Leitura compartilhada de textos \\
\hline & Desenvolvimento de simulação em programas de computador \\
\hline & Produção de vídeos \\
\hline & Jogos teatrais/dinâmicas \\
\hline & Lista de exercício \\
\hline & Situações-problema \\
\hline & Estudo de caso \\
\hline
\end{tabular}


44. Quais as atividades avaliativas você geralmente desenvolve com seus alunos?

45. Você se sente preparado para atuar ao mesmo tempo na Educação Básica de nível médio técnico quanto na Educação Superior (bacharelado, licenciatura e tecnólogo)? ( ) sim ( ) em parte ( ) não

Comente:

46. Quais estratégias didático-pedagógicas você desenvolve para estabelecer a gradação de um mesmo conteúdo entre os diversos níveis e modalidades que atua?

47. Sobre o desenvolvimento de políticas educacionais para a educação profissional como o professor se vê nesse processo? Assinale o item que mais expressa sua percepção:

\begin{tabular}{|l|l|}
\hline & $\begin{array}{l}\text { Agente indutor na formação da agenda política (apresentando a necessidade } \\
\text { de ação do estado) }\end{array}$ \\
\hline & Consultor de temáticas relacionadas às políticas a serem implementadas \\
\hline & Participante ativo nas decisões de implementação da política \\
\hline & Receptor passivo da política \\
\hline & Agente sem autonomia para executar a política \\
\hline & Indutor institucional da implementação da política \\
\hline & Avaliador ativo da política propondo seu aperfeiçoamento em nível institucional \\
\hline & Avaliador ativo da política propondo seu aperfeiçoamento em nível regional \\
\hline & Avaliador ativo da política propondo seu aperfeiçoamento em nível nacional \\
\hline
\end{tabular}

48. Para finalizar complete a frase: "Ser um bom professor do IFB é" 


\section{$8 \underbrace{}_{\substack{\text { Programade } \\ \text { Pos-Graduaça }}}$ \\ em Educaçāo \\ Universidade de Brasília \\ Programa de Pós-Graduação em Educação \\ Mestrado em Educação \\ Grupo de Estudos e Pesquisas sobre Formação e Atuação de \\ Professores/Pedagogos}

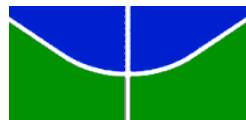

Esta pesquisa propõe analisar a particularidade do trabalho docente na verticalização do Instituto Federal de Brasília (IFB) a partir das determinações específicas da educação profissional e tecnológica (EPT), na totalidade de uma política pública educacional brasileira de expansão da EPT e do Ensino Superior. Na busca pela compreensão do trabalho docente no contexto da verticalização, a pesquisa busca identificar quais elementos constituem a verticalização do trabalho docente na EPT. Para isso, contamos com sua colaboração ao nos conceder essa entrevista e agradecemos sua disponibilidade e nos colocamos à sua disposição para quaisquer esclarecimentos.

Pesquisadora responsável: Blenda Cavalcante de Oliveira

Orientadora: Prof ${ }^{a}$. Dr ${ }^{\mathrm{a}}$. Shirleide Pereira da Silva Cruz (FE-UnB)

Objetivo geral da pesquisa: Analisar a verticalização do trabalho docente na educação profissional e tecnológica no IFB.

Roteiro de entrevista a ser realizada com professores selecionados dos campi pesquisados:

Dados de identificação do entrevistado:
a) Nome:
b) Idade:
c) Formação inicial:
d) Área de atuação:
e) Tempo de IFB:
g) Email:
h) Telefone:

1- Como você avalia a política educacional que criou os Institutos Federais?

2- Você estava ciente das características da verticalização antes de entrar no IFB?

3- Como você vê a verticalização do Ensino Médio ao Ensino Superior proposta pelos IFs?

4- Como você realiza a transição do currículo do Ensino Médio e do Ensino Superior e/ou outras modalidades e etapas no seu trabalho como professor?

5- Quais as necessidades formativas que sente no exercício da docência no contexto da verticalização no IFB?

6- Como você vê a questão das condições de trabalho diante das características da verticalização no seu campus? Acha que isso interfere no seu trabalho como professor?

7- De modo geral, quais os limites e possibilidades que a verticalização apresenta para o seu trabalho docente?

8- Há elementos positivos no processo do da verticalização no IF?

9- Há elementos negativos no processo da verticalização no IF? 
Roteiro de entrevista a ser realizada com representante sindical selecionado entre os campi pesquisados:

1- Como você avalia a política educacional que criou os Institutos Federais?

2- Você estava ciente das características da verticalização antes de entrar no IFB?

3- Como você vê a verticalização do Ensino Médio ao Ensino Superior proposta pelos IFs?

4- $\mathrm{O}$ percentual de professores sindicalizados no IFB é baixo. Como você avalia essa questão?

5- Quais as propostas do sindicato para o trabalho e a formação dos professores do IFB? Nelas são consideradas as características da verticalização? Por quê?

6- Como o Sindicato vê a questão das condições de trabalho diante das características da verticalização no IFB? Como essas características podem interferir no trabalho docente?

Roteiro de entrevista a ser realizada com Diretor Geral e Diretor de Ensino selecionados entre os campi pesquisados:

1- Como você avalia a política educacional que criou os Institutos Federais?

2- Você estava ciente das características da verticalização antes de entrar no IFB?

3- Como você vê a verticalização do Ensino Médio ao Ensino Superior proposta pelos IFs?

4- Como você gerencia a questão da divisão de carga horária entre os docentes do campus diante das características da verticalização?

5- Como você vê a questão das condições de trabalho diante das características da verticalização no campus? Acha que isso interfere no seu trabalho como Diretor Geral?

Roteiro de entrevista a ser realizada com Coordenador Pedagógico selecionado entre os campi pesquisados:

1- Como você avalia a política educacional que criou os Institutos Federais?

2- Você estava ciente das características da verticalização antes de entrar no IFB?

3- Como você vê a verticalização do Ensino Médio ao Ensino Superior proposta pelos IFs?

4- Quais as necessidades formativas você acredita que são necessárias para o exercício da docência no Ensino Médio e no Ensino Superior simultaneamente?

5- Como você vê a questão das condições de trabalho diante das características da verticalização no seu campus? Acha que isso interfere no seu trabalho como Coordenador Pedagógico?

6- Há elementos positivos no processo do da verticalização no IF?

7- Há elementos negativos no processo da verticalização no IF? 